Editora Poisson

\title{
Educação no Século XXI - Volume 23 Gestão e Políticas Públicas
}

\author{
1a Edição
}

Belo Horizonte

Poisson

2019 
Editor Chefe: Dr. Darly Fernando Andrade

\section{Conselho Editorial}

Dr. Antônio Artur de Souza - Universidade Federal de Minas Gerais

Msc. Davilson Eduardo Andrade

Msc. Fabiane dos Santos Toledo

Dr. José Eduardo Ferreira Lopes - Universidade Federal de Uberlândia

Dr. Otaviano Francisco Neves - Pontifícia Universidade Católica de Minas Gerais

Dr. Luiz Cláudio de Lima - Universidade FUMEC

Dr. Nelson Ferreira Filho - Faculdades Kennedy

Ms. Valdiney Alves de Oliveira - Universidade Federal de Uberlândia

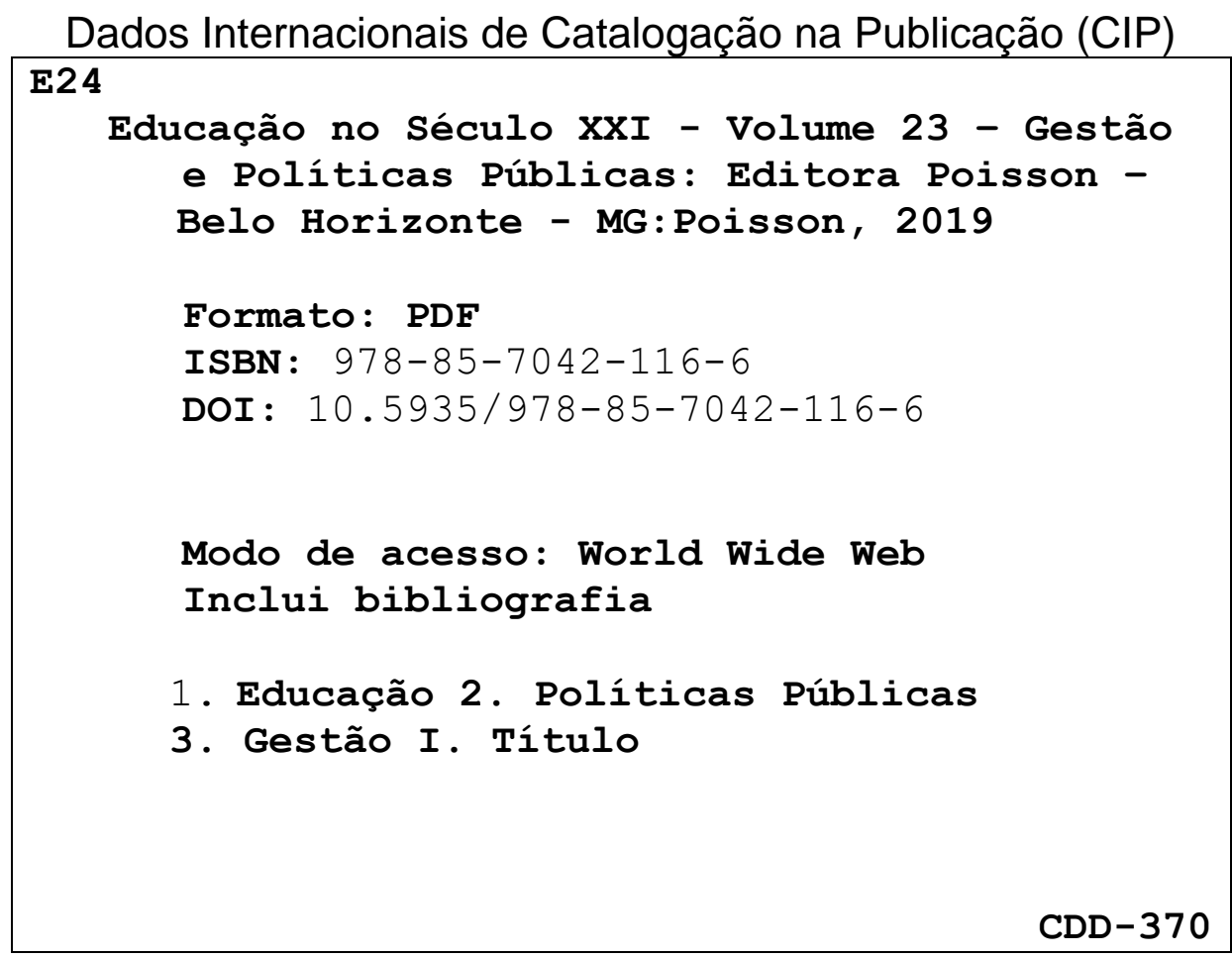

O conteúdo dos artigos e seus dados em sua forma, correção e confiabilidade são de responsabilidade exclusiva dos seus respectivos autores

$\underline{\text { www.poisson.com.br }}$

contato@poisson.com.br 


\section{SUMÁRIO}

Capítulo 1: Papel da escola pública dos anos iniciais: 0 silenciamento das suas especificidades nos documentos oficiais

Karlliny Martins da Silva

Vanda Moreira Machado Lima

Capítulo 2: A política de implantação da educação profissional brasileira: Educação, ideologia e realidade

Joelson Juk

Fausto dos Santos Amaral Filho

Capítulo 3: A educação e as inflexões neoliberais: Uma análise a partir do recorte prisional feminino

Camila Luana Teixeira Freire

Palloma Maria Gomes Jácome

Bernadete de Lourdes Figueiredo de Almeida

Capítulo 4: Intersetorialidade: políticas educacionais e a interlocução com a Psicologia expressa em dissertações. 38

Soraya Cunha Couto Vital

Joelci Mora Silva

Sônia da Cunha Urt

Capítulo 5: Mecanismos de construção da gestão democrática: Um estudo em três escolas municipais na cidade de São Luís - MA.

Katana de Fátima Diniz Boaes

Capítulo 6: A percepção dos gestores da rede municipal de ensino de dois vizinhos - PR sobre a expansão do Ensino Fundamental para nove anos

Rosangela Maria Boeno

Capítulo 7: Gestão democrática da escola: Desenhando possibilidades, repensando sua atuação 65

José Otávio da Silva

Mônica de Fátima Guedes de Oliveira

Nayane Helen Mamede Guedes 


\section{SUMÁRIO}

Capítulo 8: Gestão democrática no colégio Tiradentes de Passo Fundo: Iniciativas e interpretações 71

João Lair Alves

Eliara Zavieruka Levinski

Capítulo 9: Gestão democrática e formação política no campo da educação profissional 79

Andrezza Maria Batista do Nascimento Tavares

Ricardo Rodrigues Magalhães

Caroline Stéphanie Campos Arimatéia Magalhães

Capítulo 10: Modelos de gestão e coordenação de cursos de graduação: Um estudo comparativo em universidade pública e privada. 88

José Euzébio de Oliveira Souza Aragão

Paulo Antonio da Graça Lima Zuccolotto

Maria Aparecida Bovério

Vanessa Terra Pereira

Capítulo 11: Satisfação no trabalho e rotatividade de professores em escolas públicas estaduais 100

Marcela Iessa Schmidlin

Graziela Sapienza

Capítulo 12: A compreensão dos professores de escolas públicas acerca da progressão continuada. 107

Gilvânia Guedes Teixeira

Horácio Medeiros Júnior

Vânia Aparecida Calado

Capítulo 13: Modelo de reforma educacional Made In USA: os riscos da importação para a política educacional Brasileira 114

Luciana Dantas Sarmento da Silva

Matilde Gonçalves Mendes

Capítulo 14: A educação brasileira no meio rural: Fase desenvolvimentista- 1930 a 1990

Airton Carlos Batistela

Mariza Rotta

Everton MarcosBatistela

Mara Cristina Fortuna da Silva 


\section{SUMÁRIO}

Capítulo 15: Crítica e trajetorias na educação do/no campo: questão agrária, movimentos sociais do campo e políticas públicas.

Aníbal Simões Filho

José de Arimateia de Oliveira Silva

Severino do Ramo Pereira de Lima

Marianna Moreira Clementino Santos

Capítulo 16: Políticas públicas e currículo na educação de jovens e adultos: Impasses entre teoria e prática na criação e execução de ações para a modalidade e para os programas voltados ao público jovem e adulto.

Nivânia Ferreira da Silva

Capítulo 17:Contribuições do projeto gráfico do livro para a leitura de literatura infantil: Análise de obras do PNBE.

Manoilly Dantas de Oliveira

Sayonara Fernandes da Silva

Andrialex William da Silva

Capítulo 18: A literacia na perspectiva dos planos nacionais de leitura no Brasil e em Portugal

Maria Emília Pinto Vilarinho Rodrigues Barros Zão

Patricia Veronica Nascimento Dias Fernandes

Autores: 


\section{Capítulo 1}

\section{Papel da escola pública dos anos iniciais: 0 silenciamento das suas especificidades nos documentos oficiais}

\section{Karlliny Martins da Silva \\ Vanda Moreira Machado Lima}

Resumo: A presente dissertação foi desenvolvida e defendida no Programa de PósGraduação me Educação da UNESP - Faculdade de Ciências e Tecnologia (FCT), vinculado à linha de pesquisa "Formação dos Profissionais da Educação, Políticas Públicas e Escola Pública". Este artigo apresenta resultados da análise documental fundamentada em Cellard (2010) que realizamos na Lei de Diretrizes e Bases da Educação Nacional no 9.394 de 20 de dezembro de 1996 (LDB/96) e na Resolução CNE no. 7 de 14 de dezembro de 2010 (RESOLUÇÃO 7/2010). Identificamos que nos documentos analisados há uma definição do papel da Educação Básica, porém, um silenciamento sobre o papel da escola pública dos anos iniciais do Ensino Fundamental (AIEF). A partir da leitura dos documentos norteadores das atuais políticas educacionais brasileiras direcionadas aos AIEF (Plano Nacional de Educação (2014-2014) (PNE), Plano de Metas Compromisso Todos pela Educação (TODOS), Pacto Nacional de Alfabetização na Idade Certa (PNAIC), Base Nacional Comum Curricular (BNCC) e Programa Mais Alfabetização (PMALFA)), verificamos que o papel dessa escola é: alfabetizar os alunos (PNE, TODOS, PNAIC, PMALFA); formar leitores (PME, PNAIC, PMALFA); cuidar e educar (Resolução 7/2010); e letrar em todas as áreas do conhecimento (BNCC), porém, há significações sociais hegemônicas chegando à escola, por vezes, direcionando a formação dos seus sujeitos ao mínimo: ler, escrever e calcular. Contudo, faz-se urgente discutir o significado do papel da escola como espaço de formação integral de seus sujeitos pela apropriação dos conhecimentos historicamente construídos pela humanidade e a formação da cidadania.

Palavras-chave: Papel da escola. Escola pública. Ensino Fundamental. 


\section{INTRODUÇÃO}

A discussão sobre o papel da escola pública dos AIEF foi tema da minha dissertação de mestrado (SILVA, 2019), a qual teve como objetivo geral analisar o que as professoras compreendem como papel da escola pública dos AIEF considerando a realidade do lócus da pesquisa, desdobrado nos seguintes objetivos específicos: identificar o que as pesquisas acadêmicas apontam sobre o papel da escola pública dos AIEF; analisar na legislação educacional brasileira vigente, no Regimento e na Proposta Pedagógica da escola participante da pesquisa qual é o papel da escola pública dos AIEF; e discutir a complexidade do papel da escola pública dos AIEF na atuação docente.

Neste artigo, trazemos uma análise da LDB/96 e da Resolução 7/2010; assim como o qual é o papel da escola pública dos AIEF dos anos iniciais do Ensino Fundamental (AIEF) nos documentos: Plano Nacional de Educação (PNE); Plano de Metas Compromisso Todos pela Educação (TODOS); Pacto Nacional de Alfabetização na Idade Certa (PNAIC); Base nacional Comum Curricular (BNCC); Programa Mais Alfabetização (PMALFA).

A partir do estudo da legislação educacional é possível conhecer a história de um sistema, desvelar sentidos e interesses dos diversos grupos envolvidos, analisar as contradições, ter uma visão oficial da educação, por ser "[...] um registro ímpar de ideias e valores que circulam em determinada época" (VIEIRA, 2009, p.32), além de influenciarem a dinâmica da escola, pois, de acordo com Cruz (2017, p.36):

[...] o ser social docente está inserido numa série de relações sociais que apresentam diferentes perspectivas para a função social, não a reduzindo a um mero saber técnico de como saber ensinar, ela requer, em sua especificidade, reconhecer as implicações sociais do conhecimento que (re) produz.

Se almejamos um ensino de qualidade é preciso que os professores conheçam qual é o papel da escola pública, quais os interesses dos diversificados grupos, pois, como afirmam Lima e Leite (2013, p. 76) "sem compreender o papel da escola pública não se consegue compreender o papel do professor e, consequentemente, não se constroem condições de atuar em busca de uma transformação desse contexto desalentador".

\section{METODOLOGIA}

As análises foram realizadas a partir das contribuições de Cellard (2010) o qual enfatiza a importância do olhar crítico sob o documento a ser analisado, e nos indica cinco dimensões que contribuem a esta criticidade: o contexto; o ator ou os autores; a autenticidade e a confiabilidade do texto; a natureza do texto; os conceitos chaves e a lógica interna do texto.

O contexto está relacionado a evidenciar e considerar na análise do documento a conjuntura política, econômica, social e cultural na produção do documento, para que possamos depreender os interesses implícitos na letra dos documentos. Na segunda dimensão, Cellard (2010, p. 300), nos orienta a descrever quem são os autores, considerando e evidenciando a ideologia, a origem social e os possíveis interesses dos sujeitos.

Autenticidade e confiabilidade do texto compõem a terceira dimensão, a qual se refere a descrever na análise como ocorreu a elaboração do documento. A natureza do texto é a quarta dimensão a ser considerada em que devem constar as questões subjetivas do documento: qual seu suporte; a quem se destina; quem terá acesso a ele.

Por último, os conceitos-chave estão relacionados às palavras utilizadas no documento em análise: qual o sentido das palavras; usos de jargões específicos; uso de gírias, linguagem popular; regionalismo. A partir de então examinar a relação entre a palavra usada e o contexto em qual está inserida. Quanto à lógica interna do texto, esta tem relação com a estrutura, organização do documento e argumentos presentes no documento, isto é, o desencadeamento dos argumentos e das partes do documento (CELLARD, 2010).

Para organizarmos as funções que são atribuídas à escola pública dos AIEF nas legislações e nos documentos nos fundamentamos em Libâneo, Oliveira e Toschi (2012).

Ao abordarem a organização geral do trabalho na escola, os autores subdividem as atividades em: organização da vida escolar; organização do processo de ensino-aprendizagem; organização das atividades de apoio técnico-administrativo; organização das atividades que asseguram as relações entre escola e comunidade. 
Neste artigo, subdividimos as atribuições que são conferidas à escola em quatro segmentos de funções, sendo elas: Funções técnico-administrativas, Funções pedagógico-curriculares, Funções do professor dos AIEF, Funções socioinstitucionais. Podemos sintetizar as atribuições de cada segmento de funções em:

a) Funções técnico-administrativas: condições do espaço físico; administração dos recursos e de pessoal; distribuição do tempo escolar considerando critérios pedagógicos e curriculares; atividades da secretaria escolar.

b) Funções pedagógico-curriculares: suportes pedagógico-didáticos ao trabalho docente; assistência pedagógica e acompanhamento da execução do plano de ensino; currículo; formação continuada.

c) Funções do professor: atribuições relacionadas diretamente ao processo de ensino e de aprendizagem dos alunos.

d) Funções socioinstitucionais: Atividades que asseguram a relação entre escola e comunidade; participação dos pais na gestão escolar; são as relações externas com vistas ao aprimoramento do ensino e educação dos alunos.

Para que pudéssemos trazer à discussão o que as últimas políticas do contexto educacional brasileiro entendem como papel da escola pública dos AIEF realizamos um estudo do Plano Nacional de Educação (PNE), do Plano de Metas Compromisso Todos pela Educação (TODOS), do Pacto Nacional de Alfabetização na Idade Certa (PNAIC), da Base Nacional Comum Curricular (BNCC) e do Programa Mais Alfabetização (PMALFA).

\section{0 QUE COMPETE AOS AIEF NA LDB/961}

O Ensino Fundamental, que abrange do primeiro ao nono ano, consta no documento, especificamente, somente em três artigos, os quais trazem considerações sobre a organização e estrutura do ensino para contemplar a formação básica do cidadão. Não há nenhuma menção a especificidade dos AIEF, mas sim a finalidade para toda essa etapa da Educação Básica. A única seção destinada ao Ensino Fundamental é a Seção III.

Com a análise dos documentos podemos inferir a presença da ideologia capitalista de governo neoliberal devido ao interesse na educação como meio de qualificação de mão de obra, uma vez que, a expressão

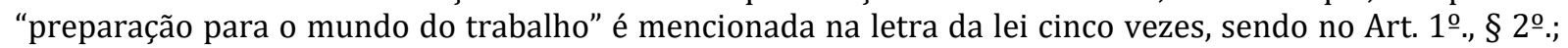
Art. 2으., Art. 3ํ., IX; Art. 22 e Art. 27.

Consideramos que qualificar para o mundo do trabalho seja uma meta de formação estabelecida para todo o processo escolar, não se tratando de um objetivo específico dos AIEF, o que nos permite inferir que há a ausência de definição do que realmente se espera como objetivo da escola dos anos iniciais, ou de como esta etapa do ensino contribuiria a esta formação para o trabalho.

0 Art. $3^{\circ}$., nos apresenta os princípios que devem fundamentar todo o ensino, dentre os quais destacamos alguns termos favoráveis à educação: liberdade, respeito, valorização, gestão democrática, qualidade.

A palavra princípio é entendida como base, razão primeira, as raízes da educação brasileira, e não como obrigação. Logo, observa-se que no primeiro item da lista de princípios consta a questão da igualdade e condições de acesso. 0 que já é favorável à educação, porém, ao Estado não fica a obrigatoriedade, justamente por se tratar de um princípio.

Adiante, o papel do Ensino Fundamental é retomado no capítulo $V$ ao trazer a questão da Educação Especial, a qual deve ser oferecida preferencialmente na rede regular de ensino (BRASIL, 1996, Art. 58). 0 mesmo artigo traz, em seu parágrafo $1^{\circ}$. a possibilidade de apoio especializado para atender às peculiaridades dos alunos de Educação Especial, o que nem sempre acontece na realidade das escolas.

0 Art.5ํ. $§ 1^{\circ}$., estabelece como competência do poder público, logo da escola, fazer a chamada e zelar pela frequência dos alunos, junto aos pais e responsáveis, cabendo à escola comunicar, quando necessário, os casos de excesso de faltas injustificadas. Logo, o professor na sala de aula tem que se preocupar e acompanhar a frequência de todos os seus alunos, onde por vezes ocorre excesso de faltas por questões de

1 A LDB/96 em análise é a versão mais atual, em sua 13ạ edição, na qual constam todas as alterações realizadas nestes 22 anos decorridos o que inclui as últimas mudanças ocasionadas pela Lei Ordinária no. 13415 de 16 de fevereiro de 2017 (Poder Legislativo) e pela Medida Provisória no. 746 de 22 de Setembro de 2016 (Poder Executivo com a presidência de Michel Temer - PMDB). 
cunho social, a título de exemplo: cuidar do irmão menor para a mãe trabalhar; problemas de saúde por falta de alimentação adequada.

No inciso VI fica estabelecido que também deve ser assegurado o processo de avaliação do rendimento escolar nas etapas da Educação básica: Ensino Fundamental e Ensino Médio, e no Art. 24 consta que a escola deve avaliar contínua e cumulativamente seu alunado.

Concordamos que os alunos devam ser avaliados continuamente, no entanto, não há nada de específico, nenhuma diretriz de como isto deve ocorrer com alunos dos AIEF. Não desejamos, nem compreendemos a LDB/96 como um manual de como proceder no processo de ensino e aprendizagem, mas o documento trata de diretrizes.

No Art. 12, temos uma lista de funções técnico-administrativas às escolas, agregando tarefas relacionadas à administração e organização das escolas para o seu bom funcionando além das responsabilidades dos professores, o que obviamente, se inclui ao papel da escola: zelar pela aprendizagem dos alunos, promover meios de recuperação aos alunos de menor rendimento; proporcionar a articulação escola-famíliacomunidade escolar (BRASIL, 1996).

Nos chama a atenção o Art. 26 §1ํ․, o qual sofreu várias alterações e até um "erro", ou uma possível omissão da redação final. Na primeira versão consta que:

$\S 1$ o. Os currículos a que se refere o caput devem abranger, obrigatoriamente, o estudo da língua portuguesa e da matemática, o conhecimento do mundo físico e natural e da realidade social e política, especialmente do Brasil (BRASIL, 1996, Art. 26, grifos nosso).

Em 2016, esta redação foi alterada pela MP no. 746 comandada pelo presidente Michel Temer do Partido do Movimento Democrático Brasileiro (PMDB), em que um detalhe que poderia ser mínimo e passar despercebido é modificado:

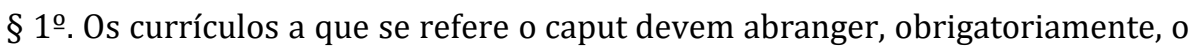
estudo da língua portuguesa e da matemática, o conhecimento do mundo físico e natural e da realidade social e política, especialmente da República Federativa do Brasil, observado, na educação infantil, o disposto no Art. 31, no ensino fundamental, o disposto no Art. 32, e no ensino médio, o disposto no Art. 36 (Redação dada pela Medida Provisória no. 746, de 2016) (BRASIL, 1996, Art. 26, grifos nossos).

De acordo com o que consta no site do planalto, a segunda versão não foi aceita quando a MP no. 746 tornou-se a Lei ํㅡ. 13.415, de 16 de fevereiro de 2017. No entanto, conforme o arquivo atualizado em março de 2017 e disponível pelo Senado Federal a versão final desse parágrafo ficou de acordo com a alteração realizada pela MP no. 746 do presidente Michel Temer.

Vamos pensar: por que tanta importância atribuída à expressão "realidade social e política, especialmente do Brasil" (versão original) e "realidade social e política, especialmente da República Federativa do Brasil"?

Há muita diferença em considerar no ensino o Brasil com toda sua história que se inicia com os indígenas até o capitalismo contemporâneo; e trabalhar com a realidade social e política do Brasil pós Proclamação da República. A partir do que ficou estabelecido pelo governo de Michel Temer, a realidade deverá ser considerada em partes, sem contextualizar, sem conhecer as raízes, o que facilita a manutenção do discurso ideológico da classe dominante.

Pensando na especificidade dos AIEF, isto influencia diretamente na formação crítica e humana do aluno. É importante nessa etapa do ensino que os alunos conheçam as suas origens e daqueles que estão ao seu redor, pois influencia diretamente, a título de exemplo na capacidade de se reconhecer como sujeito da história, de respeitar a si mesmo e ao próximo, valores essenciais para a vida em sociedade.

Outra alteração na redação se deu com o § $2^{\circ}$. do Art. 26. A Lei no․ 12.287, de 2010, ano em que o Brasil era governado por Lula (PT), acrescentou à $\mathrm{LDB}$, que o ensino de arte deveria dar atenção especial às expressões regionais, o que demonstra a valorização do contexto em que a escola e assim os sujeitos estão inseridos.

Com a MP no. 746, a redação deste parágrafo substituiu a expressão "nos diversos níveis da educação básica" por "da educação infantil e do ensino fundamental", o que altera a etapa em que este ensino deve ser considerado por excluir, no caso, o Ensino Médio e a Educação de Jovens e Adultos (EJA), modalidades 
que também eram contempladas anteriormente. Também foi excluída deste parágrafo a frase "de forma a promover o desenvolvimento cultural dos alunos" (BRASIL, 1996, Art. 26).

0 Art. 26, fixa a obrigatoriedade do ensino da língua Portuguesa e da matemática; do conhecimento do mundo físico e natural e da realidade social e política; do ensino da arte; da educação física; assim como a obrigatoriedade aos alunos do Ensino Fundamental e Ensino Médio o ensino da história e cultura afrobrasileira e indígena. Analisamos que neste artigo há um cuidado em elencar as especificidades que devem ser consideradas na elaboração dos currículos considerando as três modalidades de ensino.

Os temas transversais, de acordo com a atual redação ficam a critério do sistema de ensino, os princípios da proteção e defesa civil e a educação ambiental, que antes eram obrigatórios, passaram a ser facultativos aos sistemas. Grande perda para a educação que busca a formação integral dos seus sujeitos.

É possível observarmos o embate entre partidos políticos, com o inclui e exclui parágrafos, incisos e palavras chaves em artigos. No governo do PT são incluídos no currículo assuntos relevantes ao bem estar pessoal e ao bem da humanidade (proteção, defesa civil e educação ambiental). No governo do PMDB estes temas ficam a critério do sistema de ensino.

Notamos a complexidade do papel da escola ao não ter as especificidades determinadas em cada etapa do Ensino Fundamental, anos iniciais e anos finais. Por exemplo, o domínio da base alfabética é uma capacidade a ser adquirida pelo aluno nos AIEF por ser o alicerce para a aquisição da escrita e da leitura fluente, porém, não é possível esperar de um aluno do quinto ano a compreensão do sistema político e da tecnologia. Compreender envolve assimilar, abranger, carregar em sua essência.

A partir da análise das redações alteradas no decorrer desses mais de 20 anos da LDB/96, identificamos duas linhas de pensamentos que se divergem: uma direcionada à racionalização do ensino, qualificação de mão de obra, desconsideração da história do Brasil, tentativa de oferta de um ensino mínimo. Enquanto na outra extremidade, vemos a consideração da diversidade, o reconhecimento de todas as etapas da educação, preocupação em ofertar programas suplementares à educação e saúde, olhar cuidadoso pela frequência da criança à escola, busca por uma base nacional comum.

Enfim, verificamos que na letra da LDB/96 há várias funções administrativas e itens relacionados à organização e estrutura da escola, além da formação a ser oferecida aos seus sujeitos e tarefas que envolvem todo o processo educacional, porém, não há especificamente, definição de objetivos, metas, nem funções ou o estabelecimento do papel da escola dos AIEF, e nem distinção entre alunos de 6 anos e 14 anos de idade o que dificulta a definição do que realmente se espera de uma escola dos AIEF.

No Quadro 1, temos as funções destinadas às escolas públicas do Ensino Fundamental:

\section{Quadro 1 - Funções da escola pública do Ensino Fundamental na LDB/96}

Funções técnico-administrativas
- $\quad$ Recensear anualmente as crianças e adolescentes em idade escolar;
Fazer-lhes a chamada pública;
Administrar seu pessoal e seus recursos materiais e financeiros;
Assegurar o cumprimento dos dias letivos e horas-aula estabelecidas;
- $\quad \begin{aligned} & \text { Realizar o cadastro nacional e assegurar aos educandos com deficiência, transtornos globais } \\ & \text { do desenvolvimento e altas habilidades ou superdotação: currículos, métodos, técnicas, recursos } \\ & \text { aqueles que não puderem atingir o nível exigido para a conclusão do ensino fundamental, em virtude } \\ & \text { de suas deficiências, e aceleração para concluir em menor tempo o programa escolar para os } \\ & \text { superdotados. }\end{aligned}$


Quadro 1 - Funções da escola pública do Ensino Fundamental na LDB/96 Funções pedagógico-curriculares

- Proporcionar igualdade de condições para o acesso e permanência na escola;
-
-
Respeitar pluralismo de ideias e de concepções pedagógicas;
- Zelar pela aprendizagem dos alunos;
- Oferecer o AEE aos que necessitam deste.
- Prover meios para a recuperação dos alunos de menor rendimento de preferência paralelos
ao período letivo, para os casos de baixo rendimento escolar;
- Possibilitar a aceleração de estudos para alunos com atraso escolar, assim como o avanço nos
cursos e nas séries mediante verificação do aprendizado;
- $\quad$ Aproveitar os estudos concluídos com êxito;
- Pelar pelo cumprimento do plano de trabalho de cada docente;
Proporcionar serviços de apoio especializado, na escola regular, para atender às
peculiaridades das crianças com necessidades educacionais especiais, quando necessário, com
professores especializados;
- Assegurar professores do ensino regular capacitados para a integração dos alunos com
necessidades educacionais especiais na sala regular.
necessidades educacionais especiais na sala regular.

\section{Funções do professor}

- Ensinar considerando o vínculo ao mundo do trabalho e à prática social.

- Respeitar a liberdade de aprender, ensinar, pesquisar e divulgar a cultura, o pensamento, a arte e o saber;

- Valorizar a experiência extraescolar dos alunos;

- Considerar a diversidade étnico-racial;

- Participar do processo nacional de avaliação do rendimento escolar no ensino fundamental;

- $\quad$ Estabelecer estratégias de recuperação para os alunos de menor rendimento;

- Assegurar aos seus sujeitos a formação comum indispensável para o exercício da cidadania e fornecer-lhe meios para progredir no trabalho e em estudos posteriores.

- Verificar o rendimento escolar por meio da avaliação contínua e cumulativa do desempenho do aluno, com prevalência dos aspectos qualitativos sobre os quantitativos e dos resultados ao longo do período sobre os de eventuais provas finais;

- Contribuir ao desenvolvimento da capacidade de aprender, tendo como meios básicos o pleno domínio da leitura, da escrita e do cálculo, a compreensão do ambiente natural e social, do sistema político, da tecnologia, das artes e dos valores em que se fundamenta a sociedade;

- Capacitar os sujeitos tendo em vista a aquisição de conhecimentos e habilidades e a formação de atitudes e valores; o fortalecimento dos vínculos de família, dos laços de solidariedade humana e de tolerância recíproca em que se assenta a vida social.

- Abranger, obrigatoriamente, nos currículos o estudo: da Língua Portuguesa; da Matemática; do conhecimento do mundo físico e natural; da realidade social e política; das Artes; da Educação Física; da História do Brasil.

- Trabalhar com projetos e pesquisas envolvendo os temas transversais, o que inclui o estudo dos símbolos nacionais, os conteúdos relativos aos direitos humanos, dos direitos das crianças e dos adolescentes e à prevenção de todas as formas de violência contra a criança e o adolescente, (a critério do sistema de ensino);

- Exibir filmes de produção nacional;

- Possibilitar o acesso aos níveis mais elevados do ensino, da pesquisa e da criação artística, segundo a capacidade de cada um. 
- Articular-se com as famílias e a comunidade, criando processos de integração da sociedade com a escola;

- Elaborar com a participação dos profissionais da educação e da comunidade escolar e local sua proposta pedagógica e executá-la;

- Informar pai e mãe, conviventes ou não com seus filhos, e, se for o caso, os responsáveis legais, sobre a frequência e rendimento dos alunos, bem como sobre a execução da proposta pedagógica da escola;

- Notificar ao Conselho Tutelar do Município, ao juiz competente da Comarca e ao respectivo representante do Ministério Público a relação dos alunos que apresentem quantidade de faltas acima de cinquenta por cento do percentual permitido em lei.

- Difundir os valores fundamentais ao interesse social, aos direitos e deveres dos cidadãos, de respeito ao bem comum e à ordem democrática;

- $\quad$ Preparar para o exercício da cidadania e sua qualificação para o trabalho.

Fonte: Elaborado pelas autoras (2018).

\section{PNE, PME E TODOS: ALFABETIZAR E ATINGIR ÍNDICES}

Dentre as diversas políticas do contexto educacional temos o PNE e o TODOS.

Antes do término deste PNE, no ano de 2009, durante o governo Lula, iniciaram as discussões sobre o PNE 2011-2020 com diversas conferências, em que representantes eleitos de diversos segmentos participaram. Dentre as conferências destaca-se a Conferência Nacional de Educação (CONAE) ocorrida em Brasília. No mês de dezembro do ano de 2010, foi apresentado o projeto de lei referente a este PNE pelo então ministro da Educação Fernando Haddad (MILITÃO; PERBONI; MILITÃO, 2011).

No entanto, foi somente em 25 de junho de 2014, que foi aprovada a Lei no. 13.005 que sanciona o PNE com vigência de dez anos, o qual possui 20 metas e diversas estratégias.

O documento elaborado pelo MEC em parceria com a Universidade Federal de Pernambuco (UFPE), com contribuições da Associação Nacional de Política e Administração da Educação (ANPAE) intitulado "Planejando a próxima década: conhecendo as 20 metas do Plano Nacional de Educação", nos possibilitou o acesso à algumas análises e informações sobre cada uma das metas.

0 documento faz menções referentes aos AIEF no que concerne a: análise do aumento do IDEB; disparidades do IDEB entre as regiões brasileiras; aumento da proficiência em língua portuguesa e matemática; taxas de aprovação; dados referentes à formação inicial e continua dos que atuam com esta etapa do ensino

Dentre vários pontos que encontramos no PNE, destacamos o estabelecimento do terceiro ano dos AIEF como o prazo máximo para a alfabetização dos alunos, evidenciando o papel específico aos AIEF: alfabetizar as crianças até o segundo ano do Ensino Fundamental.

No entanto, essa alfabetização gera dúvidas para os professores, devido às diversas concepções de ensino em que o Brasil está construindo sua história da educação. No documento consta que:

A alfabetização hoje não pode mais ser considerada uma (de) codificação mecânica de letras e sílabas; ela deve ser entendida em relação à efetiva participação da criança nas práticas de letramento às quais se encontra exposta, dentro e fora da escola. Assim, torna-se necessário tomar os usos e as funções da língua escrita com base na elaboração de atividades significativas de leitura e escrita nos contextos em que vivem as crianças (BRASIL, 2015).

A definição de alfabetização do PNE reafirma a complexidade do papel da escola dos AIEF uma vez que na meta 5 consta que todas as crianças devem ser alfabetizadas até o final do terceiro ano, desconsiderando os diversos níveis de aprendizagem, seus diferentes tempos e ritmos. Também está determinado que a qualidade da educação deve ser aferida por meio de índices, os quais desconsideram o contexto escolar: 
Meta 7: fomentar a qualidade da educação básica em todas as etapas e modalidades, com melhoria do fluxo escolar e da aprendizagem, de modo a atingir as seguintes médias nacionais para o Ideb: 6,0 nos anos iniciais do ensino fundamental; 5,5 nos anos finais do ensino fundamental; 5,2 no ensino médio (BRASIL, 2014, p. 10).

No documento é ressaltado o aumento gradativo que tem ocorrido com o IDEB dos AIEF, no entanto, a partir dos diálogos da pesquisa de mestrado da qual as análises apresentadas neste artigo fazem parte, verificamos que há uma priorização do ensino da língua portuguesa e da matemática em detrimento das demais disciplinas devido às avaliações externas, o que minimiza o currículo, prejudica o aprendizado do aluno.

Outro documento que atrela a qualidade da educação aos índices de avaliações externas, é o Decreto n⿳o . 6.094, de 24 de abril de 2007, o qual dispõe sobre a implementação do TODOS. Este decreto é fruto do movimento Todos pela Educação, o qual é financiado pela iniciativa privada, objetivando o direito à educação básica de qualidade a todas as crianças e jovens brasileiros.

O movimento do TODOS, composto pela elite econômica, surgiu a partir da Campanha Nacional pelo direito à Educação, impulsionada por organizações civis que participaram da Cúpula Mundial de Educação em Dacar (Senegal) no ano de 2000 (LIBÂNEO; OLIVEIRA; TOSCHI, 2012).

Vinte e oito diretrizes foram postas aos municípios e estados que aderiram ao Compromisso Todos pela Educação. Para a aferição da qualidade da educação e verificação do cumprimento das metas fixadas no termo de adesão do compromisso é estabelecido o IDEB, o qual é calculado:

[...] a partir dos dados sobre rendimento escolar, combinados com o desempenho dos alunos, constantes do censo escolar e do Sistema de Avaliação da Educação Básica - SAEB, composto pela Avaliação Nacional da Educação Básica - ANEB e a Avaliação Nacional do Rendimento Escolar (Prova Brasil). (BRASIL, 2007, Art. 3ํ).

Conforme mencionado, estas metas são destinadas a toda a educação básica, exceto o item que estabelece a idade máxima de oito anos para alfabetizar as crianças.

Em sete de dezembro de 2010, foram fixadas as Diretrizes Curriculares Nacionais para o EF de nove anos as quais estão articuladas as Diretrizes Curriculares Nacionais Gerais para a Educação Básica (Resolução CNE/CEB no. 4/2010). Passamos a verificar o que o documento indica como papel da escola pública dos AIEF.

\section{AS ESPECIFICIDADES DO PAPEL DA ESCOLA PÚBLICA DOS AIEF NA RES. 7/2010}

Selecionamos a Resolução 7/2010, para análise por se tratar da compilação da mudança no EF quanto ao seu tempo e ter força de lei, além de também por sabermos que a ampliação impôs mudanças à escola quanto a reorganização estrutural, elaboração da proposta pedagógica, formação de professores, currículo, planejamento, e podem influenciar a concepção dos professores sobre o papel da escola e sua atuação, uma vez que, ao se determinar que a criança deva ingressar no EF com 6 anos de idade há uma concepção de desenvolvimento infantil, de ensino e aprendizagem, assim como de processo de alfabetização e letramento.

Diferente da LDB/96, a Resolução 7/2010 com seus 50 artigos, diversos parágrafos e incisos, deixa evidente a preocupação com as especificidades dos AIEF, assim como com as fases de transição de uma etapa do ensino para outra.

Para Santos (2010, p. 840), esta extensão do documento é uma evidência de que há preocupação em atender "[...] diferentes aspetos da educação escolar e representa uma tentativa de contemplar os interesses de diferentes grupos". Em contrapartida, vemos nesta dupla contemplação a complexidade do papel da escola pública.

Ao elencarmos o papel da escola neste documento temos no Art. 5‥: promover aprendizagens significativas; atender as necessidades e especificidades de cada aluno; ter como princípio a equidade; assegurar o ingresso, permanência e sucesso na escola.

Na Resolução 7/2010, temos como objetivo no Art. 7ํ., inciso III "a aquisição de conhecimentos e habilidades, e a formação de atitudes e valores como instrumentos para uma visão crítica do mundo", o 
que se assemelha ao Art. 32 da LDB/96 com exceção da expressão "como instrumentos para uma visão crítica do mundo".

Acreditamos que a participação dos educadores críticos na elaboração do Parecer 11/2010 ocorreu de maneira ativa e não foi desconsiderada no percurso entre Parecer e Resolução, não somente pelo que consta na letra da Resolução, mas pela conotação que pode ser aderida à formação.

O currículo nesta Resolução deve valorizar o conhecimento que os alunos dispõem e articulá-los aos conteúdos escolares (BRASIL, 2010b, Art. 9…).

No Art. $2^{\circ}$., é explicitado que o ensino não ocorre somente com as aulas, mas também em todas as experiências vivenciadas pelos alunos, desde as atitudes de todos os profissionais da escola que estão sendo vistas por estes sujeitos às falas direcionadas a eles ou a outrem. Consequentemente, cabe à escola ser um ambiente educativo, o que demanda agir com coerência com o que se ensina, ou seja, ter uma equipe ciente e comprometida do quanto influencia na formação dos alunos.

No Art. 20, a Proposta Pedagógica deve ser elaborada pelos professores, funcionários de apoio, alunos, pais de alunos, pessoas que moram nos arredores da escola, a partir de uma gestão democrática.

A Resolução determina a integração dos conhecimentos escolares e a interdisciplinaridade como necessárias e acrescenta que este trabalho articulado favorece a valorização dos conhecimentos dos alunos e contextualização, ou seja, é função da escola integrar os conhecimentos escolares e planejar considerando a interdisciplinaridade.

Também relacionado ao ato pedagógico, consta no Art. 24, §3‥ "Os projetos propostos pela escola, comunidade, redes e sistemas de ensino serão articulados ao desenvolvimento dos componentes curriculares e às áreas de conhecimento [...]" (BRASIL, 2010b).

É comum nas escolas ouvir questionamentos e até mesmo queixas sobre desenvolver projetos de outras secretarias, redes ou da comunidade que são enviados à escola. No entanto, temos neste parágrafo uma regulamentação da prática, ou seja, tais instituições tem o direito de propor os projetos às escolas, porém, como traz o mesmo artigo estes projetos devem estar articulados ao que é trabalhado na escola.

Neste sentido, é papel da escola desenvolver projetos externos desde que estes estejam de acordo com o currículo da escola e assim o desenvolvimento poderá ser articulado aos conteúdos que devem ser trabalhados.

Há indagações sobre ser ou não função da escola tratar de assuntos relacionados ao cuidado, mesmo que constam nos currículos escolares. Interessante esclarecimento é dado no Art. 23 ao trazer que ao se implementar a Proposta Pedagógica, a escola deve tratar como indissociáveis o cuidar e educar, o que demandará por vezes articular-se com serviços de apoio, políticas de outros setores com vistas a " [...] assegurar a aprendizagem, o bem-estar e o desenvolvimento do aluno em todas as suas dimensões". (BRASIL, 2010b, Art. 23).

A Resolução 7/2010, acrescenta que a escola deve também assegurar a reposição das aulas aos alunos com frequência insuficiente, evitando a retenção por faltas.

0 documento enfatiza que o trabalho a ser desempenhado, principalmente nos três primeiros AIEF seja lúdico, isto é, que tenha prazer funcional, seja desafiador, que tenha dimensão simbólica - em outras palavras, que esteja relacionado aos conhecimentos que o aluno dispõe, assim como ao seu contexto -, que o ensino seja construtivo e que os alunos possam relacionar-se durante o processo de ensino e aprendizagem.

A avaliação é entendida nesta Resolução 7/2010, como "redimensionadora da ação pedagógica". Com 4 artigos, 3 parágrafos, 9 incisos, sendo o inciso I com 4 alíneas, é tido como função da escola articular as avaliações internas e externas; expressar com clareza o que se espera dos alunos.

0 documento também pontua o papel da escola frente à educação especial, a deve propiciar as condições de acesso e permanência do aluno com necessidade educacional especial. Sobre "condições de acesso" temos no parágrafo único que acessibilidade não é somente fazer rampas na escola para cadeirantes conseguirem deslocar pelo ambiente. Compete à escola promover todos os meios necessários para a inclusão dos alunos o que inclui até mesmo material didático (BRASIL, 2010b, Art. 41).

No Quadro 2, organizamos todas as funções fixadas que fazem parte do papel da escola pública dos AIEF presente na análise da Resolução: 
Quadro 2 - Funções da escola pública dos AIEF na Resolução 7/2010 Funções técnico-administrativas

- Propiciar as condições de acesso (materiais didáticos, mobiliário, transporte, equipamentos, etc) e permanência de todos os alunos;

- Proporcionar ambiente adequado ao trabalho dos docentes;

- Ser um ambiente de inclusão digital e uso crítico das tecnologias.

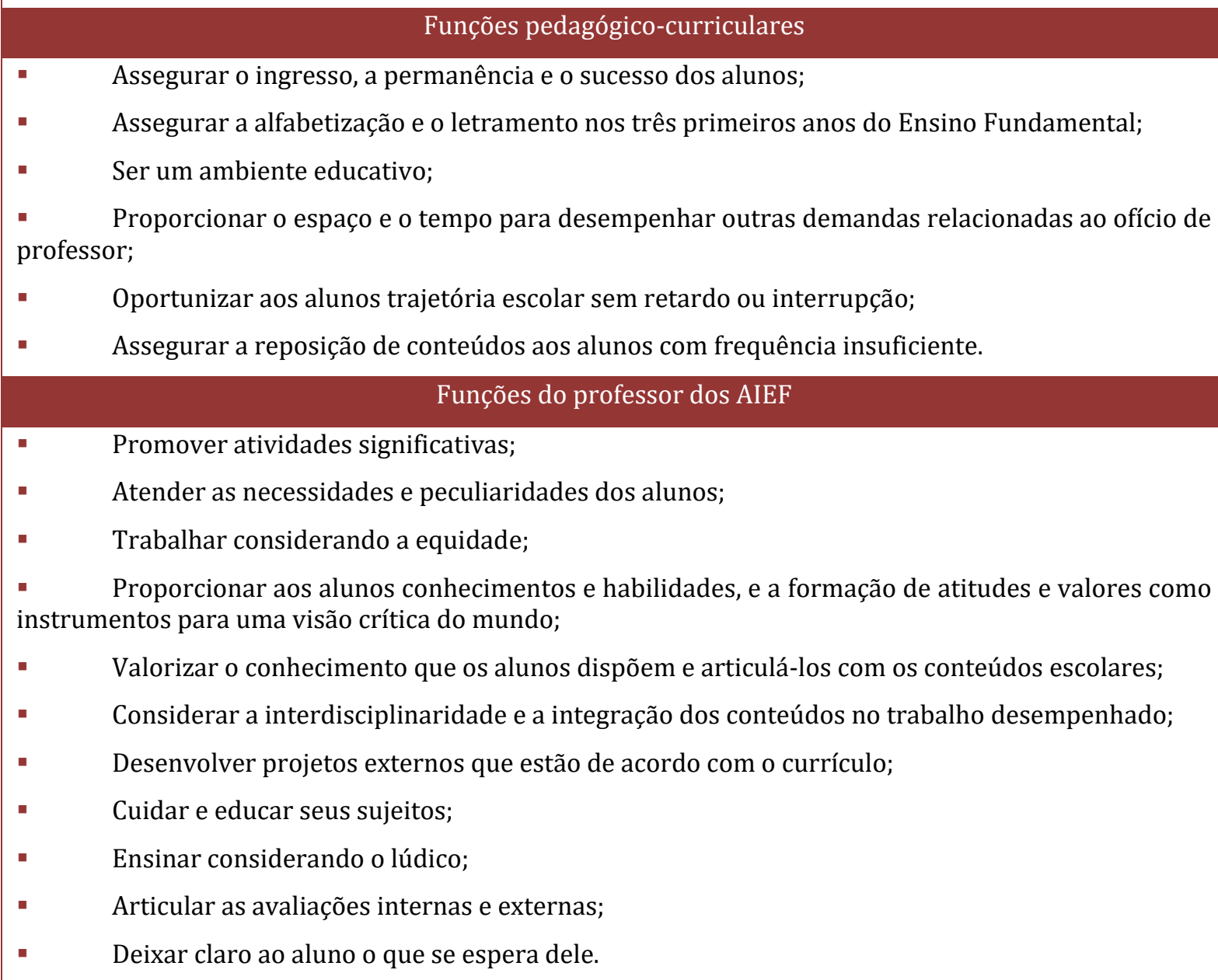

\section{Funções socioinstitucionais}

- Elaborar a Proposta Pedagógica a partir dos princípios da gestão democrática;

- Informar os responsáveis pelos alunos a frequência e o rendimento de seus filhos;

- Notificar o Conselho Tutelar, o Juiz da Comarca e o representante do Ministério Público os casos de faltas acima de $50 \%$ dos dias letivos.

Fonte: Elaborado pelas autoras (2018).

\subsection{PAPEL DA ESCOLA DOS AIEF NAS POLÍTICAS PÚBLICAS: PNAIC, BNCC E PMALFA:}

O PNAIC é uma política nacional de formação de professores alfabetizadores, instituída pelo Governo Federal no ano de 2012 por meio da Portaria MEC no. 867, de 04 de julho de 2012, apresentado como "um acordo formal assumido pelo Governo Federal, estados e municípios e entidades para firmar o compromisso de alfabetizar crianças até, no máximo, 8 anos de idade, ao final do ciclo de alfabetização" (BRASIL, 2012, p. 5).

Este Pacto além de estabelecer uma meta para a alfabetização elenca direitos de aprendizagem da criança em processo de alfabetização em todas as áreas do conhecimento e insere avaliações de aprendizagem 
para os alunos do 2ํ․ ano a Provinha Brasil, e aos alunos do 3ํ. ano dos AIEF a Avaliação Nacional da Alfabetização (ANA).

A proposta de alfabetizar as crianças até os oitos anos de idade já havia sido estabelecida como meta no ano de 2007 pelo TODOS, depois em 2010 fixado pela Resolução 7/2010, e retomada em 2014 quando aprovado o atual PNE.

O documento traz como novidade a contemplação de todas as áreas do conhecimento no processo de alfabetização, não reduzindo o currículo em língua portuguesa e matemática, apresentando uma proposta organizada por eixos estruturantes e objetivos de aprendizagem, numa perspectiva espiral de ensino, fazendo uso das nomenclaturas iniciar, aprofundar e consolidar para designar como tais eixos e objetivos devem ser contemplados. 0 programa previa além da formação dos professores, distribuição de materiais didáticos (SILVA, 2014).

Segundo Silva (2016), o programa apresenta incoerência entre a proposta de alfabetização que considera os direitos de aprendizagem dos alunos nas diversas áreas do conhecimento e a avaliação de perspectiva curricular reducionista e, como afirma Cury (1987, p.119) “indutora de práticas de treinamento", pois:

O objetivo da educação passa a ser um bom desempenho nos exames, provas e arguições. Nesse sentido, a educação acaba por se tornar um processo voltado para a submissão às ordens recebidas, que refletem e reproduzem as estruturas de dominação [...].

Para Silva (2016, p.182), a relação entre formação dos professores e avaliação da aprendizagem "[...] deposita sobre os professores uma carga muito grande de responsabilidade, ao desconsiderar outros fatores relacionados às desigualdades intra e extraescolares [...]".

De acordo com o que é proposto no documento, o professor deve avaliar continuamente, avaliar cumulativamente, e permanentemente, verificar e registrar a aprendizagem dos alunos, o que consideramos complicado de se atender se pensarmos nas diversas peculiaridades de uma sala de aula: quantidade de alunos, níveis de aprendizagem, quantidade de conteúdos a serem trabalhados.

Uma política curricular, com caráter de indicação de base do atual contexto educacional brasileiro é a BNCC, o qual deve ser usado na elaboração dos currículos e propostas pedagógicas de todas as redes de ensino, possui um conjunto de aprendizagens essenciais para as três etapas da Educação básica, organizado nas áreas de conhecimento: linguagem, matemática, ciências da natureza, ciências humanas, e ensino religioso.

É favorável à educação uma base comum para uma possível equidade nos conteúdos ensinados, desde que o currículo seja considerado Conforme afirmam Libâneo, Oliveira e Toschi (2012), o currículo seja considerado um direito do cidadão aos conhecimentos historicamente construídos e socializados, como garantia de formação básica comum a todos.

No entanto, não podemos ser ingênuos em acreditar que a base comum é pensada para o bem comum. Como já discutido no capítulo anterior, há luta de interesses pela escola, por isso seu papel é complexo. A contradição já é demonstrada ao afirmar que para a formação comum implica igualdade de condições no processo formativo.

A área de Linguagens a perspectiva do ensino a ser oferecido é a do letramento, considerando os campos de atuação para a divisão dos textos a serem trabalhos: campo da vida cotidiana; campo artístico-literário; campo das práticas de estudo e pesquisa; Campo da vida pública. Ainda dentro da área de linguagem, temos arte e educação física.

Esse documento aponta que o componente de arte contribuirá com a alfabetização e letramento dos alunos por meio do "acesso à leitura, à criação e à produção nas diversas linguagens artísticas" (BRASIL, 2017, p. 107).

No componente curricular educação física são tematizadas práticas corporais, inserindo o movimento humano no âmbito cultural, ou seja, as práticas corporais são consideradas textos culturais passíveis de leitura e produção (BRASIL, 2017, p. 212).

Considerando a quantidade de habilidades que constam nos componentes curriculares da área de linguagem é possível identificar que o ensino da língua portuguesa é priorizado no documento com um total de 204 habilidades. Em artes temos 26 habilidades e em educação física 27 habilidades. 
A parte que contempla a matemática na BNCC está organizada nas unidades temáticas: números, álgebra, geometria, grandezas e medidas, probabilidade estatística, com um total de 126 habilidades a serem adquiridas do primeiro ao quinto ano do EF.

A perspectiva do letramento também é dita como compromisso em ciências da natureza, "que envolve a capacidade de compreender e interpretar o mundo (natural, social e tecnológico), mas também de transformá-lo com base nos aportes teóricos e processuais das ciências" (BRASIL, 2017, p. 319).

A orientação é que o ensino ocorra a partir de situações de aprendizagens para atender às 38 habilidades a serem adquiridas pelos alunos dos AIEF, que estão subdivididas em três unidades temáticas: matéria e energia; vida e evolução; terra e universo.

A área de ciências humanas composta pelos componentes curriculares geografia e história busca contribuir com a formação ética e a construção do senso de responsabilidade por parte dos alunos.

A partir das 56 habilidades o ensino de geografia, de acordo com a BNCC, deve prover meios para que os alunos compreendam o mundo em que vivem, adquiram pensamento espacial e desenvolvam o raciocínio geográfico.

0 ensino de história na BNCC traz 52 habilidades a serem contempladas. A ideia que o documento apresenta é a o ensino do passado para compreensão do presente, e a tomada de consciência do eu, do outro e do nós.

Um dos pontos de acréscimo da BNCC ao papel da escola pública dos AIEF é o ensino de conteúdos relacionados ao uso da tecnologia.

Nos documentos anteriormente analisados a tecnologia era mencionada como recursos para auxiliar o professor em sua atuação, neste documento o professor passa ter conteúdos a serem ensinados aos alunos referentes à tecnologia, como por exemplo, na prática de produção de texto, os alunos do 1ํ․ ao 5ㅇ. ano deverão adquirir a habilidade de utilizar software, programas de editar texto, publicar texto e explorar os recursos multissemióticos (BRASIL, 2017, p. 93).

Destaca-se a necessidade de formação continuada aos professores para que este ensino das tecnologias ocorra, além de investimentos em recursos tecnológicos paras escolas.

Com o levantamento do que as políticas do atual contexto educacional brasileiro apontam como papel da escola, podemos concluir que as últimas políticas públicas para os AIEF têm sido, em sua maioria, direcionadas à alfabetização dos alunos, com o PMALFA não é diferente. De acordo com o manual operacional do sistema de orientação pedagógica e monitoramento, o PMALFA:

[...] surgiu como uma estratégia do MEC diante dos resultados da Avaliação Nacional da Alfabetização - ANA do Sistema de Avaliação da Educação Básica SAEB, criada com o intuito de avaliar o nível de alfabetização dos estudantes, ao

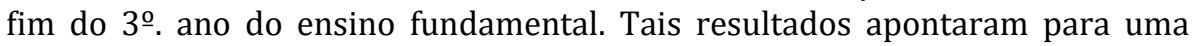
quantidade significativa de crianças nos níveis insuficientes de alfabetização (leitura, escrita e matemática) (BRASIL, 2018, p. 3-4).

0 programa afirma por meio de seus documentos que entende que as crianças aprendem em ritmos diferentes, necessitam de acompanhamento diferenciado, assim como reconhecem que a alfabetização é a base à aquisição dos demais conhecimentos, e que tem como objetivo apoiar e fortalecer as escolas no processo de alfabetização (BRASIL, 2018).

Segundo os documentos dessa política, o programa garante o apoio adicional de um assistente de alfabetização aos professores dos primeiros e segundos anos dos AIEF.

Interessante destacar, que PMALFA estabelece como meta a alfabetização dos alunos até o final do 2ํ․ ano dos AIEF.

\section{ALGUMAS CONSIDERAÇÕES}

A partir da comparação dos quadros de funções de todos os documentos analisados (Quadro 1 ao Quadro 8), verificamos que as funções técnico-administrativas, pedagógico-curricular e socionstitucionais que constam na LDB/96 e na Resolução 7/2010 de maneira sintética, são especificadas em várias ações a serem desempenhadas por todos que trabalham na escola no Regimento Comum e na Proposta Pedagógica da escola participante da pesquisa. 
Algumas das funções que constam na LDB/96 são mantidas na íntegra, inclusive com os mesmos termos nos demais documentos. Há funções a serem desempenhadas por cargos específicos, como por exemplo, expedir histórico, o que compete ao secretário e ao diretor da escola.

Resumidamente, trata-se de funções que evidenciam a dinâmica de funcionamento de qualquer modalidade e estabelecimento de ensino formal, ou seja, não são especificidades da escola dos AIEF. 0 papel da escola no que concerne ao sujeito que se almeja formar consta na categoria funções do professor.

Com este análise, identificamos que na LDB/96 há um silenciamento quanto ao papel da escola pública dos AIEF, considerando suas especificidades. Constatamos que esse documento traz o papel da Educação Básica, que vem a ser a formação para o mercado de trabalho, a necessidade de se articular escola-famíliasociedade, de ensinar valores e atitudes, e considerar os aspectos avaliativos qualitativos acima dos quantitativos, destoando este último do PNE o qual insere a ideia de aferir a qualidade da educação por meio de índices quantitativos, através de avaliações de habilidades e competências em Língua Portuguesa e Matemática.

A Resolução 7/2010 enfatiza a importância de se olhar para cada aluno como um sujeito único, em que o cuidar e educar como indissociáveis tendo como princípio o prazer em aprender e o lúdico no processo de ensino e aprendizagem para uma formação de cidadãos críticos. Diferente dos outros documentos, a avaliação, aqui, é entendida como instrumento para acompanhamento da aprendizagem e redirecionamento da prática docente.

A BNCC, que norteará a elaboração e reelaboração dos currículos das redes e Sistemas de Ensino a partir deste ano, também foi ponderada pelas vozes deste trabalho. Esse documento aponta que a escola de Educação básica deve letrar os alunos em todas as áreas do conhecimento. No entanto, para as vozes desta pesquisa, a quantidade excessiva de conteúdos, habilidades e competências a serem contempladas poderá prejudicar a qualidade do ensino oferecido.

Em suma, identificamos que as últimas políticas públicas para a educação - PNE, TODOS, PNAIC, PMALFA, BNCC, estão concentradas na alfabetização e têm direcionado o papel da escola dos AIEF a alfabetizar os alunos, formar leitores, cuidar, educar e letrar em todas as áreas do conhecimento.

Na LDB/96 está determinado que à escola compete a formação para o trabalho, o que também encontramos no PME, porém, em ambos documentos isto é dito como tarefa da educação básica, e não como uma especificidade dos AIEF. Não há uma definição do papel da escola dos AIEF. Acréscimo considerável há no PME com relação à LDB/96: formar leitores.

O PNE e o TODOS trazem que o papel da escola é alfabetizar todos os alunos, o mesmo que consta no PNAIC e no PMALFA. Uma função destinada aos dois primeiros anos do EF.

Conforme mudam os sujeitos que frequentam a escola o seu papel é redefinido, porém, a escola deve ter como princípio o ensino do que é histórico, os conhecimentos já construídos, o que é necessário à manutenção e sobrevivência da nossa espécie, aquilo que não será ensinado em nenhum outro lugar.

A escola precisa ser uma instituição do conhecimento (LIBÂNEO, 2012), atentando-se ao controle do sistema de ensino do mínimo, que está sendo exercido por meio de políticas de avaliação camufladas no discurso da busca pela melhoria da qualidade do que está sendo oferecido e às questões sociais que por vezes podem limitar o papel da escola à socialização, à convivência, ao acolhimento social.

É necessário que a escola considere o contexto social, histórico e econômico em que está inserida em toda a sua dinâmica de organização e estabelecimento do que e como se deve realizar o ensino formal, porém, não pode se sujeitar às demandas da sociedade na definição do seu papel.

Lima (2007), ao resgatar a história do ensino formal, relembra que a escola surgiu da necessidade de preencher o ócio de um determinado grupo minoritário que desfrutava dos benefícios do trabalho de outro grupo. Mediando a vida em sociedade a educação proporcionava ao homem a produção de sua própria existência e a preservação de sua espécie.

Para Di Giorgi e Leite (2010), o interesse no ensino elementar surge a partir das transformações da sociedade brasileira com a evolução da indústria e do comércio para que este atendesse as necessidades do sistema.

Pelo fato da escola estar inserida em um contexto de conflito de interesses seu papel torna-se complexo, marcado pela ambiguidade e contradição, pois, conforme afirma Rios (2011, p. 45) "em cada sociedade a estrutura da organização do trabalho configura de modo peculiar o processo educativo, a tarefa da 
educação escolar", visto que a escola pode ser tanto instrumento de manutenção do sistema, quanto meio de transformação da realidade por meio da formação integral do aluno.

Daí a necessidade de discutir sobre o papel da escola pública dos AIEF, e de formação política para a compreensão dos caminhos que estão sendo designados e trilhados por essa escola há tempos, o que suscita à necessidade de se repensar a formação política dos professores, tanto inicial quanto continuada.

Segundo Silveira (1995, p.25) a escola pode exercer transformador a realizade a partir de sua função mediadora:

[...] que consiste na sua possibilidade de proporcionar as massas populares o acesso aos conhecimentos e habilidades teóricos e práticos necessários para uma compreensão científica, rigorosa e crítica da realidade em que vivem, tornando-as, assim, melhor instrumentalizadas para a luta pela sua libertação.

No entanto, isso só ocorre se a escola tiver conhecimento deste seu papel e de que é "palco de contradições, campo de batalha onde se confrontam as forças da dominação e as forças da libertação" (SILVEIRA, 1995, p. 21).

Concluímos que o papel da escola pública dos AIEF é contribuir com a formação integral do ser humano, considerando o cuidar e o educar como indissociáveis, ensinando os conteúdos referentes à higiene, aos valores, ao respeito ao próximo, como também o cálculo, a escrita, a leitura, o entendimento de mundo, mediante a interdisciplinaridade das diferentes disciplinas, sem a desvalorização da Arte, da Educação Física, da Ciências, da Geografia e da História.

\section{REFERÊNCIAS}

[1] Brasil. Lei de Diretrizes e Bases da Educação Nacional. Lei no 9394, 20 de dezembro de 1996. Brasília, 1996. Disponível em: <http://www.planalto.gov.br/ccivil_03/leis/L9394.htm>. Acesso em: 02 abr. 2017.

[2] Brasil. Ministério da Educação. Conselho Nacional de Educação Câmara de Educação Básica. Resolução no 4, de 13 de julho de 2010. Disponível em: <http://portal.mec.gov.br/dmdocuments/rceb004_10.pdf>. Acesso em: 01 abr. 2017.

[3] Brasil. Decreto no. 6.094, de 24 de abril de 2007. Dispõe sobre a implementação do Plano de Metas Compromisso Todos pela Educação, pela União Federal, em regime de colaboração com Municípios, Distrito Federal e Estados, e a participação das famílias da comunidade, mediante programas e ações de assistência técnica e financeira, visando a mobilização social pela melhoria da qualidade da educação básica. Casa Civil, Brasília, DF, 24 abr. 2007. Disponível em: <http://www.planalto.gov.br/ccivil_03/_ato2007-2010/2007/decreto/d6094.htm>. Acesso em: 10 ago. 2018.

[4] Brasil. Portaria MEC no. 867, de 04 de julho de 2012. Institui o Pacto Nacional pela Alfabetização na Idade Certa e as ações do Pacto e define suas diretrizes gerais. Ministério da Educação, Brasília, DF, 04 jul. 2012. Disponível em:<http://pacto.mec.gov.br/images/pdf/port_867_040712.pdf>. Acesso em: 10 ago. 2018.

[5] Brasil. Instituto Nacional de Estudos e Pesquisas Educacionais Anísio Teixeira. Plano Nacional de Educação PNE 2014 - 2024: Linha de Base. Brasília, DF: Inep, 2015. Disponível em:<http://portal.inep.gov.br/documents/186968/485745/Plano

+Nacional+de+Educa\%C3\%A7\%C3\%A3o+PNE+2014-2024++Linha+de+Base

12c6fc77700f?version=1.1>. Acesso em: 12 out. 2018.

[6] Brasil. Ministério da Educação. Base Nacional Comum Curricular: Educação é a base. Brasília, 2017. Disponível em: http://portal.mec.gov.br/index.php?option=com_ docman\&view=download\&alias=79601-anexotexto-bncc-reexportado-pdf-2\&catego ry_slug=dezembro-2017-pdf\&Itemid=30192>. Acesso em: 15 ago. 2018.

[7] Brasil. Ministério da Educação. Secretaria de Educação Básica. Programa Mais Alfabetização: Manual operacional do sistema de orientação pedagógica e monitoramento. Brasília, 2018. Disponível em:< http://portal.mec.gov.br/docman/ abril-2018-pdf/85691-manual-operacional-pmalfa-final/file>. Acesso em: 15 ago. 2018.

[8] Cellard, André. A análise documental. In: Poupart, Jean; Deslauriers, Jean-Pierre; Groulx, Lionel-H.; Laperrière, Anne; Mayer, Robert; PIRES, Álvaro. A pesquisa qualitativa: enfoques epistemológicos e metodológicos. Tradução de Ana Cristina Arantes Nasser. Petrópolis, Rio de Janeiro: Vozes, 2010, p. 295-316.

[9] Cruz, Shirleide Pereira da Silva. Professor polivalente: profissionalidade docente em análise. 1ed. Curitiba: Appris, 2017.

[10] Cury, Carlos Roberto Jamil. Educação e contradição: elementos metodológicos para uma teoria crítica do fenômeno educativo. São Paulo: Cortez: Autores e associados, 1987. 
[11] Di Giorgi, Cristiano Amaral Garboggini; Leite, Yoshie Ussami Ferrari. A qualidade da escola pública, na perspectiva democrática e popular. Série-Estudos - Periódico do Programa de Pós-Graduação em educação da UCDB. Campo Grande, MS, n. 30, p.305-323, jul./dez., 2010.

[12] Libâneo, José Carlos. Oliveira, João F; Toschi, Mirza S. Educação Escolar: políticas, estrutura e organização. 10.ed.rev.ampl. São Paulo: Cortez, 2012. p. 509- 539.

[13] Lima, Vanda Moreira Machado. Formação do professor polivalente e saberes docentes: um estudo a partir de escolas públicas. 2007. 280 p. (Doutorado em Educação) - Faculdade de Educação da Universidade de São Paulo, São Paulo, 2007. Disponível em: <file:///C:/Users/Win10/Downloads/vanda_moreira_machado_lima.pdf>. Acesso em: 06 jul. 2016.

[14] Lima, Vanda Moreira Machado; Leite, Yoshie Ussami Ferrari. Ensino Fundamental: papel social, especificidades e representações dos professores dos anos iniciais. In: PIMENTA, Selma Garrido; Pinto, Umberto de Andrade. (Org.). 0 papel da escola pública no Brasil contemporâneo. São Paulo: Edições Loyola, 2013, p. 75-106.

[15] Militão, Sílvio Cesar Nunes; Perboni, Fábio; Militão, Andreia Nunes. O novo PNE (2011-2020): convergências e divergências. In: X Congresso Nacional de Educação Educere. I Seminário Internacional de Representações Sociais, Subjetividade e Educação - SIRSSE. Curitiba: Pontifícia Universidade Católica do Paraná, 2011.8103-8116. Disponível em:<http://educere.bruc.com.br/CD2011/pdf/5866_3463.pdf>. Acesso em: 10 out 2018.

[16] Rios, Teresinha Azerêdo. Ética e competência. 20 ed. São Paulo: Cortez, 2011, v.7.

[17] Silva, Cátia Cilene Farias da. O Pacto Nacional pela Alfabetização na Idade Certa - Pnaic: entre méritos e críticas de uma política educacional. Crítica Educativa, Sorocaba, v. 2, n. 1, p. 178-185, jan./jun. 2016. Disponível em: <http://www.criticaeducativa.ufscar.br/index.php/ criticaeducativa/article/viewFile/13/213>. Acesso em: 13 set. 2018.

[18] Silva, Karlliny Martins da. O papel da escola pública a partir das vozes dos professores: isto e/ou aquilo? 2019. 223 p. Dissertação (Mestrado em Educação) - Faculdade de Ciências e Tecnologia, Universidade Estadual Paulista, Presidente Prudente. Disponível em: <https://repositorio.unesp.br/bitstream/handle/11449/181005/silva_km_me_prud.pdf?sequence=1\&isAllowed=y>. Acesso em: 13 jun. 2019.

[19] Silveira, Renê J. T. 0 professor e a transformação da realidade. Revista Nuances- Presidente Prudente, v. 1, n. 1, p. 21-30, set. 1995.

[20] Vieira, Sofia L. Base Legal. Educação Básica: política e gestão da escola. Brasília: Líber Livros, 2009. p. 31-50. 


\title{
Capítulo 2
}

\section{A política de implantação da educação profissional brasileira: Educação, ideologia e realidade2}

\author{
Joelson Juk \\ Fausto dos Santos Amaral Filho
}

Resumo: Esta comunicação apresenta pesquisa sobre a política de implantação da educação profissional brasileira, que envolve diversas condições e peculiaridades como educação, ideologia e realidade. O estudo tem como objetivo compreender os significados e os impactos dessa política na formação dos profissionais para o mundo do trabalho. Metodologicamente foi orientada pela pesquisa qualitativa de natureza interpretativa a partir da análise documental, sendo subsidiada na visão dialética incorporada pela hermenêutica, sem desprezar as trajetórias escolares e acadêmicas dos pesquisadores. Isso justifica a interlocução com diversos autores, dentre os quais: Acácia Kuenzer, Antonio Gramsci, Dermeval Saviani, Friedrich Engels, Hannah Arendt, Immanuel Kant, István Mészáros, Jean Claude Passeron, Karel Kosik, Karl Marx, Octavio Ianni e Pierre Bourdieu. Com o referencial teórico e as análises dos documentos educacionais, algumas conclusões foram possíveis: a política de implantação da educação profissional ocorreu em ambiente histórico concreto no Brasil, a partir do século 20, no período da velha e da nova república e sob as influências da crise da modernidade e do processo de globalização; quando se estuda a formação profissional, deve-se levar em conta que educação, ideologia e realidade são fatores complexos e concretos, que interligam-se e compõe a totalidade da problemática; não são suficientes as análises sobre a política de implantação da educação profissional, se faz necessário um compromisso ético e pedagógico dos pesquisadores com a busca de alternativas propositivas. Ressalte-se que a pesquisa está alicerçada em uma perspectiva educacional integral, do profissional como um zoon politikon, com formação humana e técnica. Entende-se que o estudante dos cursos técnicos não deve ser apenas e tão somente preparado para o mercado de trabalho, reduzido à ideia de mão de obra e, sim, para o mundo do trabalho, onde consegue o sustento e a manutenção da vida privada, para além do capital.

Palavras-chave: Política. Educação profissional. Educação, ideologia e realidade. 


\section{INTRODUÇÃO}

As visões de mundo, de identidade nacional e de construção do conhecimento no Brasil, anacrônicas, complexas, difusas, ora explícitas ora veladas, evidenciam uma estrutura social forjada na disputa e no convencimento, ou derivado da força dos argumentos ou dos argumentos de força, que, ao fim e ao cabo, não são propriamente argumentos. De uma forma geral, no campo político, assistimos à disputa de poder entre os profissionais liberais, ruralistas, militares e religiosos. No campo educacional, disputa de espaço entre as tendências pedagógicas conservadoras e as progressistas. No campo científico, disputa entre as visões epistemológicas positivistas e humanistas. É esse o contexto concreto que interessa-nos investigar, pensar e provocar a discussão porque configura, de forma genérica, o espaço explicativo da política de implantação da educação profissional brasileira e envolve diversas condições e peculiaridades, dentre as quais: educação, ideologia e realidade.

Para a investigação, será empregada a pesquisa qualitativa de natureza interpretativa a partir da análise documental, na busca de compreensão das motivações, crenças e valores que possibilitaram a política voltada para a educação profissional no país. Essa compreensão está subsidiada na visão dialética incorporada pela hermenêutica, como ferramenta de apreensão e significação dos sentidos intrínsecos do contexto histórico concreto que permeia a formação dos profissionais brasileiros em instituições especializadas. Somado ao recorte metodológico, estão as trajetórias escolares e acadêmicas dos pesquisadores, em atividades de docência e de gestão, na rede pública e privada de educação. Assim sendo, a metodologia, as vivências concretas e os documentos científicos e educacionais perquiridos, formaram a totalidade de dados e de conhecimentos produzidos.

Para apresentar os resultados da pesquisa, optou-se por uma estrutura textual com três subtítulos: o primeiro trata o contexto da política de implantação da educação profissional brasileira, para fixar resumidamente o ambiente histórico concreto do surgimento e do desenvolvimento das ações políticas relativas à formação de profissionais no Brasil; o segundo aborda a educação, ideologia e realidade, para demonstrar em que medida uma política educacional profissionalizante está permeada por fatores complexos e concretos que precisam de análise e compreensão; o terceiro apresenta algumas considerações provocativas e propositivas, para demonstrar que é possível uma investigação teórica ser capaz de trazer contribuições reais para o entendimento e o aprimoramento de certa problemática educacional. Assim, manifesta-se o propósito do estudo, para além do julgamento do objeto pesquisado, está o compromisso em analisar, refletir e propor ideias e ações referendadas na realidade concreta e nas inquietações pedagógicas e sociais dos pesquisadores.

\section{O CONTEXTO DA POLÍTICA DE IMPLANTAÇÃO DA EDUCAÇÃO PROFISSIONAL BRASILEIRA}

No limiar do século 20, especialmente no mundo ocidental, as estruturas da sociedade moderna sofreram uma série de questionamentos por parte de setores intelectuais organizados, que identificavam um processo de ruptura do tecido social alicerçado nos ideais iluministas oriundos da Revolução Francesa, sobretudo os valores liberais positivistas. No Brasil, esse discurso de justificação da crise da modernidade explica a emergência de críticas ao modo de organização e de funcionamento da sociedade brasileira, de maneira especial nos meios científicos e educacionais. Esse fenômeno de correspondência entre as conjunturas, mundial e local, aparece como um fenômeno moderno denominado de globalização. Para Ianni (1994, p. 151), "o local e o global determinam-se reciprocamente, umas vezes de modo congruente e consequente, outras de modo desigual e desencontrado. Mesclam-se e tencionam-se singularidades, particularidades e universalidades." As transformações em curso na sociedade brasileira, no período acima citado, evidenciam esse movimento globalizante. Representam o impacto das mudanças culturais e sociais mundiais em escala local, em um movimento histórico dialético.

A formação do estado republicano brasileiro, os conflitos entre as classes urbanas e rurais, a emergência das classes industriais e de comerciantes, a herança do período colonial, como a política pública higienista, machista e racista, enfim, tudo que se percebia no território nacional não se diferenciava fundamentalmente do que acontecia ao redor do mundo. 0 processo de globalização criou uma espécie de vizinhança global entre as sociedades, tendo como marco a crise das instituições. No caso brasileiro, refletem essa crise, as reformas educacionais da primeira metade do século 20, entre as quais, citamos as reformas Benjamin Constant (1890-91), Epitácio Pessoa (1901), Rivadávia Corrêa (1911), Carlos Maximiliano (1915), João Luiz Alves da Rocha Vaz (1925), Francisco Campos (1932) e Capanema (1942).

A realidade local, de modo concreto, indicava a ebulição de novas ideias educacionais em contraste com as ideias educacionais tradicionais. Para compreender essa relação, Kosik (2002, p. 15) afirma que "o 
fenômeno indica algo que não é ele mesmo e vive apenas graças ao seu contrário. A essência não se dá imediatamente; é mediata ao fenômeno e, portanto, se manifesta em algo diferente daquilo que é. A essência se manifesta no fenômeno." A dinâmica histórica é complexa e precisamos analisar como aparece e como se desenvolve. Conforme Cândido (1989, p. 182), "não foi o movimento revolucionário de 30 que começou as reformas; mas ele propiciou a sua extensão por todo o País." Ainda para Cândido (1989, p. 182), "antes houvera reformas locais, iniciadas pela de Sampaio Dória em São Paulo (1920), que introduziu a modernização dos métodos pedagógicos e procurou tornar realidade o ensino primário obrigatório, com notável incremento de escolas rurais." Fica claro que a sociedade brasileira estava passando por uma transformação considerável e a escola acusava essa modificação. Buscava-se uma educação capaz de engendrar novos valores nas crianças e nos jovens, não só para prepará-los, mas sobretudo, para criar condições culturais de inserção do Brasil no mundo globalizado nascente.

Esse movimento chamado de Escola Nova representa um liberalismo educacional adiantado, que nos auxilia na compreensão das resistências encontradas, notadamente de ordem moral e religiosa. 0 país estava amadurecendo seu republicanismo democrático e a herança colonial persistia com vigor. Por exemplo, nas escolas públicas o ensino laico pretendia oferecer conhecimentos voltados para a cidadania e para o espírito científico, em detrimento do ensino religioso colonial, direcionado para a formação de fiéis com espírito contemplativo. 0 aprendizado pela experiência e pela observação entrava em choque com o dogmatismo calcado na fé e nos costumes. A crise educacional relatada refletia a crise geral da sociedade. Se, por um lado, os educadores escolanovistas acreditavam que o Brasil somente integrar-se-ia ao restante do mundo por meio do ensino científico, por outro lado, os educadores tradicionais viam nessa inserção um caminho perigoso, maléfico para o país, porque o cientificismo favorecia ao individualismo racionalista, iconoclasta e materialista.

Em síntese, esse conflito refletia a crise societária mundial em escala local, o que coincide com a chamada crise da modernidade identificada por diversos autores, como Arendt (1995, p. 221): "a crise geral que se abate sobre o mundo moderno e que atinge quase todas as áreas da vida humana manifesta-se diferentemente nos vários países, alargando-se a diversos domínios e revestindo-se de diferentes formas." Em termos filosóficos, no Brasil, não são as reformas educacionais que geram os conflitos de pensamento na sociedade, é a sociedade como um todo, em crise, que provoca a transformação das estruturas e dos valores tradicionais. A apreensão teórica dessa realidade, segundo Briceño-León (2003, p. 161), "permite o investigador/a atuar de dentro. Se aproxima da realidade do estudo de forma natural e permite colher dados ricos, através de estratégias não estruturadas." Concretamente, observamos as contradições reais manifestando-se na teia das relações sociais e nos conflitos entre as classes sociais, evidenciando-se as diferentes cosmovisões e os diversos graus de poderes antagônicos presentes na sociedade brasileira do limiar do século 20.

\section{EDUCAÇÃO, IDEOLOGIA E REALIDADE}

Nas contradições reais, o contexto histórico-social revela-se como a materialização dos interesses em conflito. Podemos dizer, então, que a nascente república brasileira foi construída pelas representações do real, os ideais positivistas. Assim, a educação passou a ocupar o papel de destaque, como fator de transformação da sociedade colonial em sociedade republicana. Nessa nova coletividade, é mister destacar também o papel do mercado de mão-de-obra livre como determinante para a consolidação das novas relações sociais, entre os representantes do estado e os da sociedade civil. A mão-de-obra livre, nesse sentido, carece de ser compreendida em sua manifestação concreta:

a República passaria a considerar, dentro dos parâmetros do pensamento liberal, o trabalho 'como condição intrínseca ao homem que só se desenvolvendo, possibilita a criação dos bens morais, pois recupera e eleva o sentido ético dos indivíduos e dos bens materiais'. 0 acúmulo de bens morais e materiais formaria a riqueza da nação (QUELUZ, 2000, p. 17).

A educação, de modo particular, aquela vinculada ao exercício profissional, passou a ser vista pelas autoridades políticas e pelas elites econômicas, como um instrumento efetivo para o desenvolvimento da nova sociedade brasileira. Por meio dela, se almejava inserir o país na seleta lista de países desenvolvidos, sobretudo, no que diz respeito aos processos internos de industrialização, tão caros ao liberalismo contemporâneo. Mostra-se oportuno e eficaz, então, pensar a educação profissional associando-a com as teorias filosóficas da segunda metade do século 19, especificamente com o positivismo. 0 Estado Positivo de Auguste Comte (1798-1857) retomava a linha desenvolvida desde o século XVII por John Locke, Francis Bacon, David Hume e os demais empiristas. 0 cientificismo e seu método, isto é, o da experimentação, 
fundava aquilo que na mentalidade da elite econômica dominante seria o engenho do desenvolvimento científico e técnico da sociedade, permitindo que o trabalho produtivo fosse incorporado à dinâmica da industrialização do século 20.

As reformas educacionais estimuladas pelo Manifesto dos Pioneiros da Educação Nova de 1932 favoreceram esse projeto desenvolvimentista, assim como as instituições recém-criadas: Ministério dos Negócios da Educação e Saúde Pública/MEC (1930); Serviço Nacional de Aprendizagem Industrial (1942); e, Serviço Nacional de Aprendizagem Comercial (1946). Para Saviani (2011, p. 245), "conclui-se, portanto, que a Educação Nova busca organizar a escola como um meio propriamente social para tirá-la das abstrações e impregná-la da vida em todas as suas manifestações". 0 autor mostra que a faceta desse projeto revela um pensamento econômico liberal e positivista, impregnado das ideias de intervenção mínima do Estado sobre a sociedade civil, liberdade de mercado e escola laica.

Estava em construção no Brasil, é importante frisar, um projeto de sociedade do consenso, que desconhece o conflito de classes sociais como um motor da história humana. Tal perspectiva liberal fica evidenciada no Programa Nacional de Educação, esboçado a partir do Manifesto dos Pioneiros da Educação Nova, por Azevedo (1932, p. 125, art. X): "reconstrução do sistema educacional em bases que possam contribuir para a interpenetração das classes sociais e a formação de uma sociedade humana mais justa e que tenha por objeto a organização da escola unificada, desde o jardim da infância à universidade [...]." A ideia de que sociedade e escola servem para a manutenção do status quo se faz presente em outros pensadores da época. A axiologia liberal, ou seja, o conjunto de valores burgueses é centrado na conviç̧ão de que igualdade, liberdade e propriedade caminham juntas e possibilitam a existência de uma sociedade onde os elementos sociais cumprem funções determinadas, com certo consentimento pacífico, crendo em princípios individuais superiores aos princípios coletivos. Podemos inferir essa visão em Teixeira (1968, p. 149):

os ideais e aspirações, contidos no sistema social democrático, envolvem a igualdade rigorosa de oportunidades entre os indivíduos, o virtual desaparecimento das desigualdades econômicas e uma sociedade em que a felicidade dos homens seja amparada e facilitada pelas formas mais lúcidas e mais ordenadas.

Vista dessa forma, a educação institucionalizada torna-se um tipo ideal, uma tábua de salvação e de legitimação. Isso fica mais evidente na ocorrência de crises econômicas, éticas, morais e políticas, inevitáveis em qualquer sociedade. 0 aparelho estatal, representante das forças ou setores hegemônicos, como pensado por Gramsci (1978), faz uso do discurso das reformas educacionais para alcançar seus objetivos difusos e/ou para legitimar sua existência como promotor de transformação e de enfrentamento das crises. É nesse sentido que podemos identificar o questionamento sobre o sistema educacional brasileiro, pós-manifesto, colocando em suspensão a pretensa harmonização dos interesses individuais com os coletivos.

Nesta perspectiva é que pensamos as reformas educacionais e a criação das escolas profissionalizantes no início do século 20 na emergente república tropical. Conforme Kuenzer (1999, p. 88): "a formação profissional como responsabilidade do Estado inicia-se no Brasil em 1909, com a criação de 19 escolas de artes e ofícios nas diferentes unidades da federação, precursoras das escolas técnicas federais e estaduais." Essas escolas foram criadas pelo Decreto n.․ 7.566, de 23 setembro de 1909, pelo presidente Nilo Peçanha. Podemos entender assim como os Institutos Federais de Educação, Ciência e Tecnologia têm parentesco institucional com os Centros Federais de Educação Tecnológica, com as Escolas Técnicas Federais e com as Escolas de Aprendizes e Artífices.

Os projetos pedagógicos das primeiras escolas profissionalizantes centravam-se na transmissão repetitiva de métodos e práticas a serem utilizadas no chão das novas fábricas e oficinas espalhadas pelo país, notadamente nos médios e grandes centros urbanos da Região Sudeste e Sul, com ensino centrado no professor e em manuais técnicos. Não havia preocupação com um processo formativo centrado nos estudantes e em material didático diversificado. As disciplinas que não estavam atreladas diretamente à formação técnica do estudante eram desprezadas ou tinham um espaço reduzido nas grades curriculares. Buscava-se a todo custo moldar o trabalhador desejado e submisso à nova ordem social. A passividade se tornara um elemento importante para a engrenagem da produtividade. 0 resultado mais evidente desse processo pedagógico tecnicista, pode-se verificar nos discursos economicistas e desenvolvimentistas de intelectuais, governantes e administradores da imprensa da época. Para a promoção de políticas ativas de desenvolvimento, que demonstravam a dependência do Brasil às potências capitalistas mundiais, afirma 
Martuscelli (2015, p. 35) que o processo:

de construção da cidadania a partir da universalização de direitos sociais garantidos pelo Estado foi substituído pela adoção de políticas compensatórias e focalizadas, bem como pela mercantilização dos serviços públicos básicos de atendimento à população, como foram os casos dos serviços educacionais e de saúde.

Na educação em geral, isso significou a divisão entre duas classes de estudantes. Por um lado, estudantes com poder aquisitivo recebiam formação intelectual clássica nas escolas privadas. Por outro lado, estudantes sem poder aquisitivo recebiam formação intelectual técnica nas escolas públicas. Como afirma Kuenzer (1999, p. 89):

para os primeiros, a formação acadêmica, intelectualizada, descolada de ações instrumentais; para os trabalhadores, formação profissional em instituições especializadas ou no próprio trabalho, com ênfase no aprendizado, quase que exclusivo, de formas de fazer a par do desenvolvimento de habilidades psicofísicas.

Na segunda metade do século 20, essa dicotomização educacional persistiu nas instituições escolares e acadêmicas. Para exemplificar melhor essa tese, nos anos de chumbo (1964-1985) provenientes do golpe militar de 1964, a tendência tecnicista da educação ampliou seu espaço nas escolas, já que favorecia o projeto dos militares de transformar os custos em educação em crescimento econômico. Isso porque os dirigentes militares estavam convencidos de que a racionalização dos processos produtivos aplicados na escola, resultaria em uma educação em série, com economia de tempo, trabalho e gastos. Tudo para atender ao ideal de desenvolvimento do país pela via do capital estrangeiro, em detrimento do capital nacional. Isso gerou um estímulo à implantação de empresas multinacionais que necessitavam de mão de obra qualificada para suas plantas industriais. Para resolver isso, os militares criaram o vestibular classificatório, implantaram o controle de atividades subversivas na escola, substituíram as disciplinas humanistas e críticas por disciplinas nacionalistas e moralistas, proibiram manifestações políticas aos professores, estudantes e funcionários das escolas, entre outras políticas de controle e julgamento. Com essa estratégia educacional equivocada e diretiva,

a organização do trabalho educativo em bases empresariais levou os ordeiros professores a se sentirem não servidores do público, mas força de trabalho vendida a um patrão chamado Estado. Este dado novo acrescenta um elemento importantíssimo na configuração da educação e definição de seus rumos (ARROYO, 1980, p. 17).

A burocratização do ensino, o controle dos conteúdos, o direcionamento dos planejamentos educacionais e o uso da repressão, em conjunto, transformaram a educação em capital humano a serviço de um projeto político de mundo que transcende a territorialidade desse ou daquele país, isto é, um projeto ancorado na lógica neoliberal globalizante, que, naquele tempo, começava a ser implantado efetivamente no país. A inclusão de Educação Moral e Cívica e de Organização Social e Política do Brasil nos currículos laureia o surgimento das disciplinas mais adequadas ao moralismo nacionalista e a pedagogia tecnicista:

não seria equivocado ver nestes dispositivos clara intenção de reestruturar a educação de modo a adequá-la às necessidades da vida produtiva, em rápida e constante mudança tecnológica e, assim, torná-la mais eficaz para responder aos desafios que o novo patamar de competitividade, agora em escala global, vêm colocando para as nações (SENAI-DN, 1997, p.11).

Isso se verifica se observarmos as legislações educacionais do período em questão. Na Lei de Diretrizes e Bases da Educação n.o 4.024, de 20/12/61, o sistema público de ensino foi diretamente atrelado ao sistema de produção liberal, como se vê no Art. 108: "o poder público cooperará com as empresas e entidades privadas para o desenvolvimento do ensino técnico e científico." Na Lei de Diretrizes e Bases da Educação n.o 5.692 de 11.08.71, determinou-se, em seu Art. 5으, § 2º, que a formação especial de currículo: “a) terá o objetivo de sondagem de aptidões e iniciarão para o trabalho, no ensino de $1^{\circ}$ grau e de habilitação profissional, no ensino de $2^{\circ}$ grau;" e, ainda, "b) será fixada, quando se destine a iniciação e habilitação profissional, em consonância com as necessidades do mercado de trabalho local ou regional, à vista de levantamentos periodicamente renovados". Na educação profissional, ressaltam-se os artigos 39 a 42 da Lei de Diretrizes e Bases da Educação no 9.394 de 20/12/96, que abrem espaço para a organização de um sistema paralelo, formalmente separado da estrutura regular de ensino. 
O art. 40 da LDB 9394/96, prevê que: "a educação profissional será desenvolvida em articulação com o ensino regular ou por diferentes estratégias de educação continuada, em instituições especializadas ou no ambiente de trabalho." Para lembrar Saviani (1998), esta lei tem caráter flexível, inespecífico e minimalista, sendo, portanto, carregada de anacronismos. Não menos preocupante, o Decreto n.o 2.208 de 17.04.97, que foi aprovado com a ideia de articulação entre a educação profissional e os setores empresariais, entendendo esses como responsáveis pela composição dos currículos, a administração e o financiamento das instituições. Aponta Kuenzer (1999, p. 105) que a educação profissional passa a ser financiada, "com recursos do FAT, dos agentes financeiros internacionais, particularmente Banco Mundial, Banco Interamericano e dos setores privados, (Sistema S, empresas e instituições privadas)." Para além da legislação educacional, encontramos em documentos de instituições privadas, a mesma lógica de escolamercado. Para exemplificar essa percepção da realidade, veja-se o que defendem os gestores do Banco Mundial (1995, p. 8): “a educação profissional dá melhores resultados quando realizada com a participação direta do setor privado em sua oferta, financiamento e direção." Entre os anos de 1970 a 1990, as disciplinas de Filosofia e de Sociologia foram banidas do currículo escolar, pois apresentavam espaços de críticas a submissão da educação à lógica de mercado.

A extinção foi a solução mais eficaz e eficiente encontrada pelos militares. Para o país, a falta de reflexão crítica nas escolas resultou em insuficiência intelectual discente e em decadência na formação docente, nas respectivas ciências humanas. Tal situação é confirmada por Pegoraro (1986, p. 11): "os professores formados antes de 64 ficaram muito tempo sem poder dar aulas e por isso estão, hoje, defasados, situados em outros espaços culturais". Nesse sentido vislumbra Valls (1983, p. 42): "no passado recente brasileiro, os professores mais brilhantes foram aposentados ou expurgados das universidades, o pensamento crítico foi perseguido e desestimulado, o pensamento dogmático, representante do arbítrio, instalou-se nas escolas." Os autores denunciam, assim, as consequências da interferência arbitrária dos militares na educação. Nas gerações de estudantes, isso favoreceu o déficit no desenvolvimento das competências e habilidades humanísticas, alicerçadas na reflexão sobre os problemas da vida em geral e do mundo do trabalho, na perspectiva da complexidade e da diversidade dos valores, conhecimentos, modos de ser e agir. $\mathrm{Ou}$, em outros termos, a militarização educacional causou um movimento de repressão cultural que corroborou para um baixo desenvolvimento da formação intelectual crítica e criativa no país. As dificuldades de encontrarmos pesquisas qualitativas e quantitativas acerca do perfil dos egressos desse sistema formal impede uma conclusão definitiva sobre o impacto no mundo do trabalho e na formação do pensamento nacional. Podemos inferir, entretanto, que a unilateralidade tecnicista orientada pelos militares na educação fortaleceu-se em detrimento da formação omnilateral dos estudantes como futuros profissionais.

\section{CONSIDERAÇÕES PROVOCATIVAS E PROPOSITIVAS}

Essa investigação da história recente da educação profissional, a rigor, demonstra que se fortaleceu o argumento da justiça educacional no Brasil, a partir da eficiência econômica, sendo o Estado responsável pela educação básica, controle institucional e o repasse dos recursos orçamentários para a formação escolar e profissional. As políticas educacionais refletem as pressões para os ajustes estruturais neoliberais e a diminuição, cada vez maior, da presença direta do poder público no sistema educacional. Ainda que possamos dizer que indiretamente o Estado, aliado aos interesses do capital, continuamente fornece as condições de possibilidade para a implementação hegemônica dos interesses do referido capital.

O caminho para a superação desse modo de concepção da política de implantação da educação profissional brasileira depende da conjuntura e da estrutura das organizações jurídicas e políticas da sociedade organizada, de modo especial, dos movimentos educacionais, populares e sindicais. Segundo Cury (2000, p. 75): "a educação reflete uma estrutura social, mas, por outro lado, fermenta as contradições". Isso porque é um processo regido pela transmissão do saber que gera poder social, na medida em que revela como a sociedade está organizada e como a mesma funciona com seu modo de produção da vida e das coisas. Pode-se superar a contradição, mas Cury (2000, p. 80) alerta que isso, "depende da função política que ela assumir". Entende-se, assim, porque as reformas educacionais não resultaram em democratização ou emancipação educacional para além das classes sociais, mas quase sempre um aprofundamento das diferenças entre as classes sociais.

É preciso considerar a (im)possibilidade de uma verdadeira reforma sistêmica no interior da própria estrutura do sistema capitalista, pois é uma contradição em termos, conforme alerta Mészáros (2008, p. 27): “é por isso que é necessário romper com a lógica do capital se quisermos contemplar a criação de uma 
alternativa educacional significativamente diferente." Para Bourdieu \& Passeron (1975, p. 220), "se não é fácil perceber simultaneamente a autonomia relativa do sistema escolar, e sua dependência relativa à estrutura das relações de classe [...]" não é porque isso decorre de um desconhecimento total da realidade concreta. Antes, continuam Bourdieu \& Passeron (1975, p. 220):

é porque, entre outras razões, a percepção das funções de classe do sistema escolar está associada, na tradição teórica, a uma representação instrumentalista das relações entre a escola e as classes dominantes como se a comprovação da autonomia supusesse a ilusão de neutralidade do sistema de ensino.

Nessa perspectiva, as subjetividades dos indivíduos são ofuscadas pelo poder de dominação da lógica totalizante da educação técnico-profissionalizante. Para ir além, utiliza-se das bases teóricas de uma racionalidade que fundamente e legitime uma espécie de educação emancipadora no sistema educacional brasileiro. A razão emancipatória deve provocar a desconfiança na razão instrumental, chamando atenção para os interesses evidentes e subjacentes que sustentam o pensamento reducionista e mecanicista do mundo real.

A estrutura educacional profissional do Brasil, especialmente na constituição e no desenvolvimento do período republicano, não se realiza de modo linear, claro ou fluído. Precisamos observar as contradições, nela presentes. Na visão de Fernandes (1966, p. 537), então, “o lado dramático e cruel da situação educacional brasileira está exatamente aí. 0 homem da camada social dominante tira proveito das deformações de sua concepção de mundo. Ao manter a ignorância, preserva sua posição de mando, com os privilégios correspondentes." A camada social dominada, desse modo, corresponde ao estrato social desorganizado, subserviente, incapaz de perceber ou desvendar as amarras tecnicizantes. Para o pensador, o projeto educacional brasileiro deveria ser construído em bases democráticas não-alienantes, cultural, moral, política e socialmente libertadoras ou, em termos sociológicos, esclarecidas.

A visão crítica da técnica pode consolidar seu espaço nas escolas como o locus privilegiado para o pensamento esclarecido, cumprindo seu papel histórico de revelação desse estado de entorpecimento da consciência humana contemporânea ou de menoridade. Para Kant (2005, p. 63): "esclarecimento (Aufklärung) significa a saída do homem de sua minoridade, pela qual ele próprio é responsável. A minoridade é a incapacidade de se servir de seu próprio entendimento sem a tutela de um outro." Mas, para quem serviria esse esclarecimento? Segundo Guareschi (1990, p. 78), "eis a grande chance duma escola: ela pode ser o local onde se forjarão novas vivências verdadeiramente comunitárias, de onde poderão surgir transformações profundas e radicais em todo o corpo social". A superação da razão instrumental ocorre em um processo educacional que estimula a imaginação, a criação, a crítica e a autocrítica.

0 mundo do trabalho substitui o mercado de trabalho da lógica do capital, se nos pautarmos em uma educação intelectual, corporal e tecnológica. A educação profissional aqui é entendida como a formação ampla, politécnica, conforme Marx e Engels (1978, p. 223): “abrangendo os princípios gerais e científicos de todos os processos de produção, e ao mesmo tempo iniciando as crianças e os adolescentes na manipulação dos instrumentos elementares de todos os ramos de indústria." Para uma melhor compreensão dessa concepção educacional, não se pode confundir os conceitos de politecnia e de tecnologia na educação, pois são apreensões teóricas e concretas com características e aplicações diferenciadas, servindo, inclusive, para atender interesses e necessidades antagônicas. Assim, diz Manacorda (1991, p. 32):

o primeiro termo, ao propor uma preparação pluriprofissional, contrapõe-se à divisão do trabalho específica da fábrica moderna; o segundo, ao prever uma formação unificadamente teórica e prática, opõe-se à divisão originária entre trabalho intelectual e trabalho manual, que a fábrica moderna exacerba.

Em síntese, a tecnologia possibilita ao ser humano uma realização em objetos e coisas externas a si mesmo, independente da sua ocupação específica. A politecnia carrega em si a ideia da multiplicidade das atividades pensadas a partir da apreensão do real, potencializando o ser humano que, justamente por ser humano, pode ser artista, comerciante, industrial, operário, político, servidor público, entre outras tantas determinações profissionais. 


\section{CONSIDERAÇÕES FINAIS}

Como uma primeira consideração, vale o registro das dificuldades na produção do texto, dada a complexidade teórica e concreta do objeto estudado. Mesmo assim, a pesquisa apresentou aprofundamento teórico-metodológico e resultados significativos para a análise, reflexão e propostas de ideias e ações, pelas escolhas de recursos, referencial teórico e técnicas de seleção das informações.

Uma segunda consideração diz respeito a compreensão do contexto político de implantação da educação profissional brasileira que trouxe conhecimentos sobre a transformações da sociedade brasileira, no limiar do século 20: as influências internacionais para a formação do estado republicano brasileiro, os reflexos da crise da modernidade nas reformas educacionais e a relação entre a globalização e o Brasil. A análise sobre a educação, ideologia e realidade apresentou esses fatores complexos e concretos, por meio de um amplo referencial teórico e documental, como capitais para identificar o surgimento e o desenvolvimento real da política educacional profissional no país, destacando a solução do governo militar em aceitar apoio dos Estados Unidos para as reformas educacionais, por meio de acordos entre o MEC e a Agência dos Estados Unidos para o Desenvolvimento Internacional. Com isso, ficou patente um sistema educacional paradoxal, com ensino profissional influenciado pela visão pedagógica dualista, formação tecnicista para estudantes pobres e clássica para estudantes de classe média e alta. As considerações provocativas e propositivas, lançaram ideias, informações e propostas para a modificação da estrutura de pensamento que permeia a educação profissional voltada para a reprodução de conhecimentos e técnicas em detrimento da criação e produção de saberes e práticas. A lógica totalizante da educação técnico-profissionalizante pode ser transformada, se convencermos professores, estudantes e gestores das instituições educacionais a valorizarem o ensino e a aprendizagem emancipada e crítica, aliando formação humana e técnica, ou seja, humanizando o processo de educação profissional.

Como última consideração, destacamos que com elementos fundantes de uma proposta educacional integral, do homem como um zoon politikon, é que a proposta desse artigo se coaduna. Não se trata de estabelecer uma resposta monolítica nem tampouco evasiva. Cabe então apontarmos uma direção, como proposta de investigação do objeto que não está longe da vivência pessoal, mas que foi estudado com cautela e certo distanciamento epistemológico, em vista de resultados advindos de experiência socialmente referendada. Diante do cenário complexo considerado até aqui, apreendendo as situações e condições históricas concretas nas quais foi implantada a política da educação profissional brasileira, vislumbramos espaços de intervenção nessa política, debates e estudos futuros sobre seu impacto o Brasil.

\section{REFERÊNCIAS}

[1] Arendt, Hannah. A condição humana. Rio de Janeiro: Forense Universitária, 1995.

[2] Arroyo, Miguel. Operários e educadores se identificam: que rumos tomará a educação brasileira? Educação e Sociedade. São Paulo: Cortez, 1980.

[3] Azevedo, Fernando et al. Esboço escrito a partir do Manifesto dos pioneiros da educação nova. (1932). Disponível em: <http://www.dominiopublico.gov.br/download /texto /me4707.pdf>. Acesso em: 22 maio 2017.

[4] Banco Mundial. Prioridades y estrategias para la educación. Examen del Banco Mundial. Washington, D.C., $1995 . \quad$ Disponível em: <http://www-wds.worldbank.org/ external/default/WDSContentServer/WDSP/IB/2005/06/13/000160016_20050613172136/Rendered/PDF/14948 010spanish.pdf>. Acesso em: 22 maio 2017.

[5] Bourdieu, P.; Passeron. A reprodução. Rio de Janeiro: Francisco Alves, 1975.

[6] Brasil. Decreto no 7.566 de 23.09.1909. Rio de Janeiro, 1909. Crêa nas capitaes dos Estados da Republica Escolas de Aprendizes Artifices, para o ensino profissional primario e gratuito. Disponível em: <http://www2.camara.leg.br/legin/fed/decret/1900-1909/decreto-7566-23-setembro-1909-525411publicacaooriginal-1-pe.html>. Acesso em: 24 maio 2017.

[7] _. Decreto no 2.208 de 17.04.1997. Brasília, 1997. Regulamenta o § 2 o do art. 36 e os arts. 39 a 42 da Lei no 9.394/96. Disponível em: <http://www.planalto. gov.br/ccivil_03/ decreto/D2208.htm>. Acesso em: 24 maio 2017.

[8] __. Lei no 4.024 de 20 de dezembro de 1961. Brasília, 1961. Fixa as diretrizes e bases da educação nacional. Disponível em: <http://www.planalto.gov.br/ ccivil_03/leis/14024.htm>. Acesso em: 25 maio 2017.

[9] _. Lei oㅡ 5.692 de 11.08.71. Brasília, 1971. Fixa diretrizes e bases para o ensino de $1^{\circ}$ e $2^{2}$ graus. Disponível em: <http://www.planalto.gov.br/ccivil_03/leis/l5692.htm>. Acesso em: 25 maio 2017.

[10] __. Lei no 9.394 de 20.12.1996. Brasília, 1996. Estabelece as diretrizes e bases da educação nacional. Brasília, 1996. Disponível em: <http://www.planalto.gov.br/ ccivil_03/leis/ 19394.htm>. Acesso em: 25 maio 2017. 
[11] Briceño-Leon, Roberto. Quatro modelos de integração de Técnicas Qualitativas e Quantitativas de investigação nas Ciências Sociais. In: Goldenberger, P.; Marsiglia, R.M.G; Gomes, M.H. de A. O clássico e o novo: tendências, objetos e abordagens em ciências sociais e saúde. Rio de Janeiro: Editora Fiocruz, 2003.

[12] Cândido, Antônio. A Educação Pela Noite \& Outros Ensaios. São Paulo: Ática, 1989.

[13] Cury, Carlos Roberto Jamil. Educação e contradição: elementos metodológicos para uma teoria crítica do fenômeno educativo. 7. ed. São Paulo: Cortez 2000.

[14] Fernandes, Florestan. Educação e sociedade no Brasil. São Paulo: Edusp, 1966.

[15] Gramsci, Antonio. Os intelectuais e a organização da cultura. Rio de Janeiro: Civilização Brasileira, 1978.

[16] Guareschi, Pedrinho Alcides. Sociologia crítica: alternativas de mudança. Porto Alegre: Mundo Jovem, 1990.

[17] Ianni, Octavio. Globalização: novo paradigma das ciências sociais. Revista Estudos Avançados, São Paulo: USP/IEA, vol. 8, no. 21, p. 147-63, 1994.

[18] Kant, Immanuel. Resposta à pergunta: Que é “Esclarecimento”? Petrópolis: Vozes, 2005.

[19] Kosik, Karel. Dialética do Concreto. 7. ed. São Paulo: Paz e Terra, 2002.

[20] Kuenzer, Acácia Zeneida. A reforma do ensino técnico e suas consequências. In: Educação Profissional: tendências e desafios. Curitiba: SINDOCEFET-PR, 1999.

[21] Manacorda, Mario Alighiero. Marx e a pedagogia moderna. São Paulo: Autores Associados, 1991.

[22] Martuscelli, Danilo Enrico. Crises políticas e capitalismo neoliberal no Brasil. 1. ed. Curitiba: CVR, 2015.

[23] Marx, K.; Engels, F. Crítica da educação e do ensino. Lisboa: Moraes, 1978.

[24] Mészáros, István. A educação para além do capital. São Paulo: Boitempo, 2005.

[25] Pegoraro, O. Filosofia: a ressurreição depois do banimento. Rio de Janeiro: SEAF, 1986.

[26] Queluz, Gilson Leandro. Concepções de Ensino Técnico na República Velha (1909-1930). Curitiba: Cefet-PR, 2000 .

[27] Saviani, Dermeval. Da nova LDB ao novo Plano Nacional de Educação: por uma outra política educacional. Campinas: Autores Associados, 1998

[28] _. História das ideias pedagógicas no Brasil. Campinas: Autores Associados, 2011.

[29] Senai-DN. A LDB e a Educação Profissional. Rio de Janeiro, 1997.

[30] Teixeira, Anísio. Pequena introdução à filosofia da educação: a escola progressiva ou a transformação da escola. 5. ed. São Paulo: Editora Nacional, 1968.

[31] Valls, Á. A Filosofia no II Grau. Porto Alegre: Correio do Povo, 1983. 


\section{Capítulo 3}

\section{A educação e as inflexões neoliberais: Uma análise a partir do recorte prisional feminino}

\section{Camila Luana Teixeira Freire \\ Palloma Maria Gomes Jácome \\ Bernadete de Lourdes Figueiredo de Almeida}

Resumo: 0 presente estudo tem o objetivo de tecer uma breve análise das inflexões neoliberais nas políticas sociais no sistema capitalista, especificamente, a política da educação. Discutindo a criminalização da "questão social" com recorte analítico do encarceramento feminino e o cerceamento do direito à educação a esta parcela da população. A perspectiva adotada neste artigo apreende-a na análise crítica marxista, compreendendo sua relação dinâmica com a totalidade. Nesse sentido a estrutura do trabalho está pautada nos seguintes aspectos: discussão acerca das inflexões neoliberal nas políticas sociais, com direcionamento à política de educação; e faz-se necessário também uma análise acerca do encarceramento feminino como parte das estratégias punitiva do Estado para responder às necessidades provenientes da relação antagônica entre capital e trabalho. Trata-se de uma pesquisa bibliográfica e de campo realizada em 2017 no Centro de Reeducação Feminino "Maria Júlia Maranhão", em João Pessoa/ Paraíba. A análise dos dados envolve uma leitura estatística através de gráficos, embasada na crítica de estudiosos que estudam esta questão em tela. Os resultados apontam que é necessário qualificar o tempo e as condições humanas da população carcerária, de modo que as pessoas envolvidas em um projeto educativo possam passar por aprendizagens positivas e tenham possibilidades reais de construção de uma identidade pessoal e social. Um projeto de educação pode reduzir a dimensão da vulnerabilidade, dentre a qual se assinala o distanciamento dos processos de construção do conhecimento e consequente desqualificação para o trabalho.

Palavras-Chave: Políticas sociais, Educação, Neoliberalismo, Prisão, Encarceramento feminino. 


\section{INTRODUÇÃO}

O capitalismo contemporâneo é repleto de transformações oriundas de sua incessante busca pela recuperação das taxas de lucro, que sofreram uma queda tendencial com a crise estrutural que lhe assola desde meados de 1970.

Nesse contexto, o papel do Estado será redirecionado, na medida em que, se antes ele atuara ostensivamente na reprodução da força física de trabalho através de políticas sociais públicas - como era no Welfare State -, agora ele será chamado apenas a dar os suportes "mínimos", sem gastos para com a classe trabalhadora, através da retirada de coberturas sociais públicas e a destruição dos direitos sociais. Processo esse que trará implicações substantivas para as políticas sociais. Estas sofreram um processo de "pauperização" assumindo uma conotação minimalista, na medida em que são pregadas como algo que deve ser acessado via mercado e não como um direito social.

Ante a produção e reprodução das desigualdades no sistema capitalista, é possível afirmar que as prisões representam a manifestação do poder punitivo e repressor do Estado. Desde os primórdios, as prisões confinam pobres, excluídos e desempregados em sua maioria. Na contemporaneidade, as relações sociais antagônicas agudizam as expressões da "questão social", criminalizando as classes subalternas. Produto das relações de dominação e exploração entre as classes no capitalismo, a "questão social", é criminalizada e naturalizada como condição das classes mais baixas.

0 presente trabalho tem o objetivo de tecer uma breve análise das inflexões neoliberais nas políticas sociais no sistema capitalista, especificamente, a política da educação. Discutindo a criminalização da "questão social" com recorte analítico do encarceramento feminino e o cerceamento do direito à educação a esta parcela da população. A perspectiva adotada neste artigo apreende-a na análise crítica marxista, compreendendo sua relação dinâmica com a totalidade.

Nesse sentido a estrutura do trabalho está pautada nos seguintes aspectos: discussão acerca das inflexões neoliberal nas políticas sociais, com direcionamento à política de educação; e faz-se necessário também uma análise acerca do encarceramento feminino como parte das estratégias punitiva do Estado para responder às necessidades provenientes da relação antagônica entre capital e trabalho.

\section{BREVE ANÁlISE DAS INFEXÕES DO NEOLIBERAIS NAS POLÍTICAS SOCIAIS E NA EDUCAÇÃO NO CONTEXTO BRASILEIRO}

É sabido que as políticas sociais fazem parte, intrinsecamente, do processo de produção e reprodução do capital. Assim, as reações capitalistas diante dessa crise estrutural para tentar amortecê-la, como mostramos anteriormente, vão implicar substancialmente nas mesmas. Segundo Behring (1998, p. 172), "[...] a capacidade de cobertura de um padrão de proteção social é diretamente proporcional à condição do país de capitalismo central ou periférico", o que vai ser determinante quanto a configuração da política social de um país para outro. Entretanto, uma coisa é homogênea quando se fala em política social no capitalismo contemporâneo: a pressão por parte das personificações do capital pela redução dos gastos sociais, "contraditoriamente articulada ao aumento das demandas postas ao Estado não apenas pelo trabalho", ou seja, a política social está no centro do embate econômico e político desse processo.

Assim, diante desse "novo" papel que o Estado assume, as políticas sociais ganham um lugar residual, entrando "no cenário como paternalismo, como geradora de desequilíbrio, como algo que deve ser acessado via mercado, e não como direito social" (BEHRING, 1998,

p. 186), sob o argumento da escassez de recursos, colocando como necessário o corte de recursos. Dá-se início a um processo de pauperização das políticas sociais sob o trinômio: privatização (geradora de uma dualidade discriminatória entre os que podem e os que não podem pagar), focalização (assegura acesso pobre aos comprovadamente pobres) e descentralização (aqui entendida apenas como mero repasse de responsabilidades para entes da federação ou instituições privadas).

No Brasil essa situação é ainda mais cruel tendo em vista a condição periférica do país, que convive com as imposições dos países centrais, corporificados nos organismos financeiros internacionais como o Fundo Monetário Internacional (FMI) e o Banco Mundial (BM), prestigiando uma ideologia de proteção apenas para os desprotegidos, focalizando apenas uma parte da população, aquela que se encontra abaixo da linha da pobreza, enquanto os demais procuram cobertores para se protegem do frio e da fome nas vitrines do mercado. Essas orientações chegaram ao país através do Consenso de Washington, nos anos 1990, ainda no governo de Fernando Collor de Mello, ganhando sua real efetivação nos governos de Fernando Henrique Cardoso, Luís Inácio Lula da Silva, Dilma Rousseff, e agora com Michel Temer tendo como centro 
de seus governos parâmetros macroeconômicos a exemplo dosuperávit primário, a Desvinculação de Receitas da União (DRU), e o pagamento de juros e amortizações da dívida pública, além das privatizações, a centralização da carga tributária na União, e as "taxas de juros parametradas pela selic".

Assim, as políticas sociais vêm sendo esvaziadas em nome do ajuste fiscal, cujo objetivo é alimentar o superávit primário - através da DRU que suga recursos do orçamento fiscal e da Seguridade Social - que tem como principal objetivo manter crédito com o capital internacional, abrindo as portas do Brasil para a especulação financeira. Com isso, as políticas sociais vêm sofrendo privatizações - como é o caso da saúde, da previdência e da educação - além de transferir a responsabilidade das ações estatais para a sociedade civil, dando margem às políticas meramente emergenciais, descontinuadas, fragmentadas, restritivas, focalizadas na pobreza extrema, a exemplo da Assistência Social que, apesar de sua expansão no governo Lula, ainda não assumiu o estatuto de política pública - uma vez que vem sendo marcadas por políticas focalizadas, amenizadoras dos "males sociais" causados pelo capitalismo contemporâneo. Segundo Iamamoto, vive-se "[...] o legado de direitos conquistados nos últimos séculos que está sendo desmontado nos governos de orientação neoliberal, em uma nítida regressão da cidadania que tende a ser civil e política, erodindo a cidadania social" (IAMAMOTO, 2008, p.197).

Desta feita, compreende-se que a política social tem sofrido um redirecionamento, haja vista que o programa de ação para a revitalização do sistema tem como ponto de partida a diminuição do tamanho do Estado. Esse novo direcionamento, segundo Behring (2008), está voltado para a gestão da pobreza e não do seu combate ou erradicação, a exemplo das políticas de transferência de renda em curso no Brasil que apesar de terem um impacto objetivo na vida de quem às utilizam, andam distante de retirarem esses usuários da situação em que se encontram.

Esse novo cenário também influenciou o campo educacional. A nova reforma exigiu, portanto, uma maior participação dos atores sociais para a formulação de políticas sociais para a educação, assim como também na execução dessas políticas. A educação passa, então, a ser responsabilidade de outras esferas, como a do terceiro setor, a partir dessa articulação do Estado e da sociedade civil, como também pelo setor privado.

Como já sinalizado, a Política de Educação, que não se difere das demais políticas sociais, se estabelece, por um lado, como instrumento do Estado para controlar o desenvolvimento intelectual dos sujeitos e apaziguá-los nas condições a que estão submetidos. Por outro lado, consiste em respostas aos movimentos sociais que conseguiram, por meio de mobilizações e lutas, alcançar pequenos avanços que se objetivam, principalmente, em garantir uma educação de qualidade para todos, sobretudo, que não estivesse atrelada aos interesses da classe dominante. Desta forma, nesse cenário de avanços, regressos e antagônicos interesses que a educação apresenta as mais variadas expressões da "questão social".

Dado a breve análise das investidas neoliberais nas políticas sociais, é possível identificar alguns fatores que ocorrem no Brasil influenciaram a forma de gerir a educação brasileira, a partir da década de 1990. A implementação de políticas de privatização do setor público que teve início no governo Fernando Collor, com sucessão no governo de Itamar Franco, chama alguns segmentos representativos da educação para uma espécie de "pacto" entre governo e sociedade, com o intuito de discutir o Plano Nacional de Educação (PNE). A reforma orientou-se de forma a despublicizar a educação, ou seja, transferi-la para a esfera da competição privada. Assim, reduz-se a educação a lógica mercadológica, substituindo o direito em detrimento ao acesso seletivo e elitista.

\section{A EDUCAÇÃO ENCARCERADA}

De acordo com a Lei de Execução Penal (LEP), o acesso à educação é um direto assegurado a pessoa em privação de liberdade e deve ser oferecido pelo Estado. A promoção à assistência educacional no âmbito prisional brasileiro antecede a LEP. Na segunda metade do século XIX no Brasil Império, a instrução escolar destinada à população carcerária já era mencionada nas instituições prisionais. A educação era voltada para apaziguar o comportamento dos presos e tinha como principais concepções os ensinamentos religiosos e morais sob responsabilidade do capelão:

[...] a princípio a função do capelão dividia-se entre contribuir com a "educação moral" dos presos com objetivo de exortá-los ao exercício da pena de prisão com trabalho, além de proporcionar aos condenados os sacramentos da igreja apostólica católica romana [...] (VASQUEZ, 2010, p. 49). 
A Casa de Correção do Rio de Janeiro, em seu regulamento já mostrava indícios da formalização da educação na prisão, a instrução deveria ser dar em ensinar a pessoa presa a ler, escrever e contar. Mais adiante, em 1865, o Presídio de Fernando de Noronha, colocou em seu quadro de empregados uma professora de primeiras letras, com o objetivo de contribuir na

instrução primária das meninas que habitavam na ilha e/ou filhas dos presos. Aos meninos, cabia ao capelão os ensinamentos primários.

Diante destas iniciativas, em meados dos anos 1850 a 1885, com a formação de novos regulamentos penitenciários, surgiram outras questões pertinentes voltadas a instrução das pessoas presas. Exemplo disso é o indicativo para a introdução de uma biblioteca com livros que atendesse as necessidades dos presos.

A partir da crise do Governo Imperial, em 1870, além das divergências do governo com o exército e a igreja e a emersão do movimento abolicionista que foi editado o Regulamento para a Casa de Correção da Corte. Nele foi introduzido o regime moral, religioso e escolar como forma de tratamento aos presos condenados. Dessa forma, cria-se uma obrigação aos empregados responsáveis pela educação na Casa de Correção da Corte.

No Brasil República surgiram novos regulamentos penitenciários. Houve a promulgação de mudanças do Código Penal que implicou na reformulação dos conteúdos dos regulamentos. Estes novos regulamentos trouxeram inovações educacionais. Foram adicionados ao programa curricular noções de geografia, história do Brasil e os direitos e deveres morais e políticos.

As Normas Gerais do Regime Penitenciário sofreram algumas alterações no governo de Juscelino Kubitschek. No que concerne à educação, é apresentado de forma implícita o termo educação integral, com acréscimo da educação artística e instrução profissional. A educação integral agora passa ser de responsabilidade do professor.

Durante a ditadura militar novos debates ganharam destaque no cenário da área penal e prisional no país, resultando na edição de outro código penal e a sanção do Código Penal (Decreto no 1004/69) e a LEP. Cabe ressaltar que a LEP vigente defende a educação a pessoa presa como uma assistência e que sua responsabilidade passa ser do Estado.

Em linhas gerais, a ordem econômica e social estabelecida pelo sistema capitalista do final do século XVIII e início do século XIX instituiu novas categorias de crimes e demarcou uma nova clientela para as prisões: a população socioeconômica mais baixa. Nesse contexto, as prisões passam a enfrentar sérios problemas de superlotação, precariedade das instalações, altos índices de periculosidade e insalubridade. A busca por alternativas surge quando a pena, baseada unicamente na privação da liberdade, não vinha contribuindo com o seu papel de "reinserir" a pessoa presa à sociedade devido aos altos índices de violência, reincidência criminal e a não adaptação do egresso à vida em sociedade. Diversos mecanismos de defesa dos direitos humanos engendraram uma luta em favor da humanização no cumprimento das penas e do fim da violação de direitos.

Na prisão, o trabalho e a educação tornam-se mecanismos de disciplinamento dos encarcerados a fim de "reintegrá-los" à sociedade. A educação escolar é uma realidade em quase todos os estabelecimentos penitenciários espalhados pelo país, porém, enfrenta sérios problemas relacionados à falta de estrutura física e financeira, além da ausência de apoio do Poder Público na formulação de políticas públicas específicas e dos administradores desses estabelecimentos que priorizam a segurança e a vigilância, bem como a construção de novas prisões.

Quando se trata da delinquência feminina, muitos se surpreendem com o alto índice de encarceramento, bem como com as múltiplas violações de direitos. As estatísticas revelam uma realidade cruel e degradante, tanto em nível nacional como local. De acordo com Departamento Penitenciário Nacional, por meio do Levantamento de Informações Penitenciárias (Infopen) Mulheres 2018, o número de mulheres privadas de liberdade no Brasil em junho de 2016 era de 42.355 mulheres presas e uma taxa de aprisionamento de $40,6 \%$.

As problemáticas do sistema penitenciário nacional vêm se intensificando nas últimas décadas, expresso no encarceramento em massa, na violação de direitos e da sua adequada conformação aos objetivos do sistema capitalista para a população mais vulnerabilizada. No que se refere ao encarceramento feminino, há uma omissão dos poderes públicos que se manifesta na ausência de políticas públicas que considerem a mulher encarcerada como sujeito de direitos, bem como as suas especificidades biológicas advindas das questões de gênero. 
Em dados gerais, conforme o Infopen Mulheres 2018, 66\% das mulheres presas ainda não acessou o ensino médio, tendo concluído no máximo o ensino fundamental e apenas $15 \%$ da população prisional concluiu o ensino médio. 0 Levantamento destaca ainda que quatro estados do nordeste tem os índices mais altos de analfabetismo, são eles: Alagoas, Paraíba, Piauí e Rio Grande do Norte. Evidencia-se a problemática social que se tornou o sistema prisional brasileiro, no qual o aumento da população carcerária deve-se a uma política repressiva, discriminatória e de criminalização da pobreza.

\subsection{A ESCOLARIDADE DAS MULHERES PRESAS EM REGIME FECHADO DO CENTRO DE REEDUCAÇÃO FEMININO “MARIA JÚLIA MARANHÃO”, EM JOÃO PESSOA/ PARAÍBA}

Concomitante à pesquisa bibliográfica e documental, realizou-se em 2017 uma pesquisa de campo no Centro de Reeducação Feminino "Maria Júlia Maranhão", em João Pessoa/ Paraíba, buscando traçar o perfil das mulheres presas nessa instituição. A análise dos dados a seguir envolve uma leitura estatística através de gráficos, embasada na crítica de estudiosos que estudam esta questão em tela. Trata-se de dados de 125 (cento e vinte e cinco) mulheres presas a fim de compreender as especificações das mulheres que estão cumprindo pena em regime fechado no CRFMJM. ${ }^{3}$

A partir dos dados coletados, evidencia-se que $88 \%$ das mulheres presas são negras, $39 \%$ são jovens, $88 \%$ solteira, e $31 \%$ têm filhos.

Levando em consideração os dados referentes à escolaridade, objeto de discussão deste trabalho, detectase que a maioria das mulheres encarceradas é de baixa escolaridade. São $54 \%$ (n=68) que não concluíram o ensino fundamental e $6 \%(\mathrm{n}=7)$ têm o ensino médio completo, como mostra o gráfico abaixo em números reais.

GRÁFICO 1- Nível de escolaridade das mulheres presas em regime fechado no CRFMJM. João Pessoa/PB, agosto de $2017(\mathrm{~N}=125)$

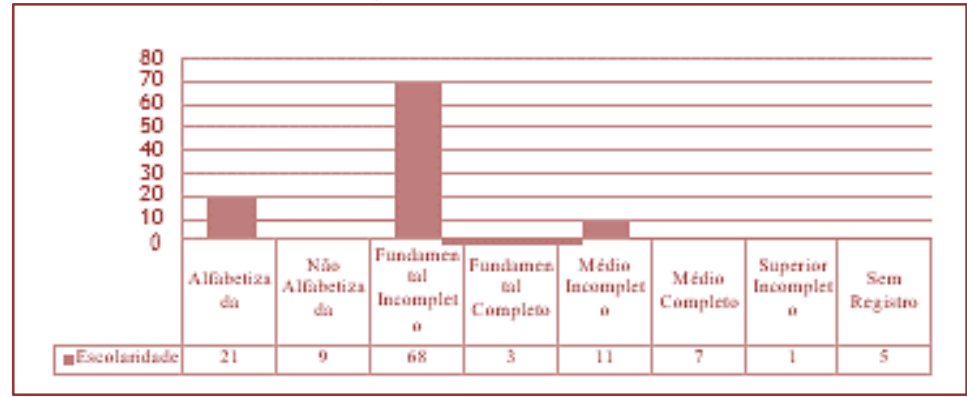

Fonte: Secundária. Elaboração própria.

Com relação aos dados aferidos no presente estudo, ressaltam-se os dados nacionais no que se refere ao baixo nível educacional da população feminina encarcerada - como já apontado nas discussões deste estudo. Concretizando que essas mulheres estão em situação de vulnerabilidade social antes mesmo de ingressar no sistema prisional.

Esses dados apontam para o déficit da Política de Educação no Brasil, principalmente no que se refere à educação pública. Mesmo sendo um direito assegurado a todos os cidadãos, verifica-se que a educação é um privilégio de uma pequena parcela da população. A vulnerabilidade social a qual está exposta à população pobre, resulta de um sistema escolar ineficaz, da ausência de capacitação profissional e da insuficiência dos postos de trabalhos.

Tais fatores aproximam a população com baixa escolaridade de soluções ofertadas pela criminalidade. 0 baixo nível de escolaridade significa dificuldade de acesso à renda, ocasionada por um mercado de trabalho que exige qualificação. Wacquant (2001) quando analisa a passagem do modelo taylorista/fordista para o flexibilizado/toyotista indica que houve sérias implicações no perfil do trabalhador porque era exigido um trabalhador mais qualificado com um perfil mais técnico. Bertoldo (2015, p. 45) afirma "Para a perspectiva burguesa, a relação entre trabalho e educação significa a 
submissão do homem ao trabalho explorado, alienado, reservando-se à educação o papel de "moldar" o indivíduo para o mercado de trabalho".

Os jovens sofrem os efeitos do déficit entre o sistema educacional e as novas imposições do mercado de trabalho. Fato este que promove a baixa autoestima e ausência de perspectivas de futuro os compelindo a lidar com as consequências de uma inserção precária nesse mercado ou a se deparar com o desemprego. É importante ressalvar que a evasão escolar não está associada predominantemente à entrada no sistema prisional.

As dificuldades econômicas advindas como resultantes desse processo geram um clima de instabilidade que pressionam jovens e, algumas vezes, crianças a buscarem formas de contribuir na subsistência da família, acarretando uma inserção prematura no mercado de trabalho informal, na maioria das vezes, ou na busca de outras formas de ganho financeiro, como por exemplo, o tráfico de drogas. Dessa forma, se encarceram cada vez mais jovens e a reclusão assume um lugar central no sistema de controle do mercado desqualificado.

As práticas educativas nas unidades prisionais devem ser pensadas a partir das suas particularidades, levando-se em consideração as condições de uma instituição penal. Neste sentido, Freire (1980) afirma que diz que a educação para ser válida deve levar em conta as condições em que o homem vive num exato lugar, momento e contexto. Assim, a modalidade adotada nas prisões é a Educação de Jovens e Adultos (EJA). Ao se abordar a EJA em situação de privação de liberdade, é relevante salientar que, embora as pessoas privadas de liberdade mantenham a titularidade dos demais direitos fundamentais, o acesso ao direito à educação lhe deve ser assegurado universalmente da mesma forma. Julião (2011, p. 149) traz

uma importante discussão sobre a educação no cenário prisional, principalmente no que se refere à aplicabilidade da EJA.

Nos artigos 17 a 21 da EJA em espaços de privação de liberdade estabelecendo como a assistência educacional ao preso e ao internado se dará

-, compreende-se como instrução escolar e formação profissional: a) obrigatoriedade do ensino fundamental; b) ensino profissional ministrado em nível de iniciação ou de aperfeiçoamento técnico; c) adequação do ensino profissional da mulher à sua condição; d) possibilidade de convênio com entidades públicas ou particulares, que instalem escolas ou ofereçam cursos especializados; e) previsão de dotar cada estabelecimento com uma biblioteca para uso de todas as categorias de reclusos, provida de livros instrutivos, recreativos e didáticos.

Nesse trecho, observa-se a restrição do sistema educacional voltado para os presídios. Apenas o Ensino Fundamental foi preceituado como sendo obrigatório no sistema prisional, não havendo garantia para o acesso ao Ensino Médio ou Superior a pessoas que cumprem pena em regime fechado. Soma-se a essa realidade a falta de estrutura das salas de aulas, de materiais didáticos e paradidáticos, e a escassez de profissionais da educação para atender a esse público específico.

\section{CONSIDERAÇÕES FINAIS}

0 combate à desigualdade e à pobreza geradoras dos processos excludentes exige princípios sociais e democráticos, cujo alcance possa representar modificações no modelo de sociedade que hoje se vive. Um projeto educativo que alcance a população carcerária pode representar a construção de nova forma de apoio a grupos minoritários e estigmatizados como o feminino que, em função dos papeis que ocupa, acaba se deparando com o mundo do crime do qual até então vinha se mantendo distante.

Para que cumpra essa finalidade, deve-se pensar em uma educação emancipadora, há de ser uma educação não reprodutora das estruturas sociais e conservadora dos ideais e crenças promotoras de exclusão e das desigualdades, hoje vivenciadas pelas classes baixas.

É necessário qualificar o tempo e as condições humanas da população carcerária, de modo que as pessoas envolvidas em um projeto educativo possam passar por aprendizagens positivas e tenham possibilidades reais de construção de uma identidade pessoal e social. Um projeto de educação pode reduzir a dimensão da vulnerabilidade, dentre a qual se assinala o distanciamento dos processos de construção do conhecimento e consequente desqualificação para o trabalho.

Destarte, a educação e demais modalidades são instrumentos que visam garantir as mulheres presas o 
acesso ao ensino, à qualificação, à reflexão, à produção de conhecimento. Precisa ser garantido inclusive o direito ao Ensino Superior em espaços de instituições prisionais. Tal proposta representa uma ação relevante para o enfrentamento das expressões da "questão social".

\section{REFERENCIAS}

[1] Behring, E. R.; Boschetti, I. Política Social: fundamentos e história. São Paulo: Cortez, 2008.

[2] Behring, E. R. Política social no capitalismo tardio. São Paulo: Cortez, 1998.

[3] Bertoldo, Maria Edna de Lima. Trabalho e educação no Brasil: da centralidade do trabalho à centralidade da política. 2ed. São Paulo: Instituto Lukács, 2015.

[4] Brasil. Ministério da Justiça. Lei de Execução Penal. № 7.210, de 11 de julho de 1984. Disponível em: http://www.planalto.gov.br/ccivil_03/leis/L7210compilado.htm. Acessado em 10 de junho de 2018.

[5] . Ministério da Justiça. Levantamento nacional de informações penitenciarias, Infopen - 2014. Disponível em: https://www.justica.gov.br/noticias/mj-divulgara- novo- relatorio-do-infopen-nesta-terca-feira/relatorio-depenversao-web.pdf\&gt. Acessado em 10 de julho de 2018

[6] Freire, Paulo. Conscientização: teoria e prática da libertação. Uma introdução ao pensamento de Paulo Freire. Tradução de Kátia de Mello e Silva. 3. ed. São Paulo: Moraes, 1980.

[7] Iamamoto, M. V. Serviço Social em tempo de capital fetiche: capital financeiro, trabalho e questão social. 2a Ed. São Paulo: Cortez, 2008.

[8] Julião, Elionaldo Fernandes. A ressocialização por meio do estudo e do trabalho no sistema penitenciário. Disponível em http://emaberto.inep.gov.br/ index.php/emaberto/article/view/2320/2283. (Acesso em 01 de novembro de 2017)

[9] Vasquez, Eliane Leal. Sociedade Cativa. Entre cultura escolar e cultura prisional: uma incursão pela ciência penitenciária. Disponível em: https://tede2.pucsp.br/handle/handle/13381. Acesso em 05 de julho de 2017.

[10] Wacquant, Loic. As Prisões da Miséria. Rio de Janeiro: Jorge Zahar. 2001. 


\section{Capítulo 4}

Intersetorialidade: políticas educacionais e a interlocução com a Psicologia expressa em dissertações 4

\section{Soraya Cunha Couto Vital}

Joelci Mora Silva

Sônia da Cunha Urt

Resumo: Este artigo provém dos estudos para realização da pesquisa "Políticas Educacionais e Formação: Produção, Projetos e Ações de Educação e Psicologia", financiada pelo Conselho Nacional de Desenvolvimento Científico e Tecnológico - CNPq (Chamada CNPq/ MCTI № 25/2015 Ciências Humanas, Sociais e Sociais Aplicadas), coordenada pela Profa. Dra. Sônia da Cunha Urt, e tem como principal objetivo propor reflexões acerca da interlocução entre as políticas e ações educacionais e a área de Psicologia, a partir das análises das dissertações que consideraram as políticas intersetoriais. Para tanto, parte da investigação das dissertações defendidas entre os anos de 2003 e 2015 nos cursos de mestrado em Psicologia no estado de Mato Grosso do Sul. 0 referencial teórico da Teoria Histórico-cultural direciona a proposição da pesquisa e embasa as análises e discussões, justaposto às contribuições dos estudiosos das políticas educacionais. Como resultado, destaca-se a importância da aproximação de diversos setores para garantir os direitos de acesso à educação pública de qualidade no Brasil, possibilitando a permanência e a conclusão dos níveis de ensino que a compõem. Consideramos que a interface entre Psicologia e Educação deve buscar defender os direitos do indivíduo no atendimento de suas necessidades educacionais e promover seu desenvolvimento.

Palavras-chave: Políticas educacionais; Intersetorialidade; Psicologia educacional.

4 Texto publicado nos Anais do III CONEDU - Congresso Nacional de Educação. Cenários Contemporâneos: a educação e suas multiplicidades. Natal-RN, 2016. 


\section{INTRODUÇÃO}

As transformações políticas pelas quais sempre passou, e passa, a sociedade brasileira, constituem-se em momento propício para as discussões que orientaram a construção de propostas de atuação nas áreas da Psicologia e da Educação e contribuem para o avanço de análises nestes campos.

Segundo Souza (2011), ao analisarmos tais políticas,

[...] partimos do pressuposto teórico de que o discurso oficial expressa uma concepção [...] de sociedade. Ou seja, nos bastidores de uma política pública gesta-se uma direção a ser dada àqueles que a ela se submetem. Embora muitas vezes tais concepções não sejam explicitadas [...], o projeto de sociedade, de homem e de mundo presente nas políticas [...] imprime uma série de valores e de diretrizes que passam a constituir as relações interpessoais e institucionais. (SOUZA, 2011, p. 234).

É preciso, então, ao tecer tal análise, considerar que, por vezes, mantém-se uma lacuna entre a política e a realidade cotidiana, por isso também deve-se ponderar sobre a capacidade de discernimento, reflexão e criticidade sobre as mesmas, a fim de que a análise possa redundar em meios efetivos de contribuir para o exercício de tal capacidade.

0 presente artigo, então, tem como principal objetivo propor reflexões acerca da interlocução entre as políticas e ações educacionais e a área de psicologia, a partir das análises das dissertações que consideraram as políticas intersetoriais. Analisar estas políticas contribuirá para a compreensão das razões das dificuldades enfrentadas pelas instituições escolares para garantir as aprendizagens fundamentais aos alunos, assim como apresentar subsídios para a proposição de políticas educacionais, com base nos conhecimentos produzidos pela Psicologia, e mais especificamente pela Psicologia Escolar e/ou Educacional.

Como referencial teórico, considera que a teoria histórico-cultural, segundo Vygotsky, concebe o ser humano em sua totalidade, configurado em sua relação social, e, por isso, propõe analisar as produções a partir de uma visão dialética do real.

A pesquisa sobre temáticas que se articulam, mas que nem sempre se mantém vinculadas, inova na tentativa de superação da fragmentação de ações e procedimentos em pesquisas e práticas educacionais e sociais. Organizar dados e analisar programas e ações de alta relevância para a Educação podem oferecer contribuições para conhecimento e estruturação de políticas e práticas sociais, educacionais e culturais para essas duas áreas - Educação e Psicologia - e para o desenvolvimento de ações mais inovadoras.

De acordo com Souza (2011), a temática das políticas públicas em educação passou a fazer parte das preocupações do campo da Psicologia Escolar/Educacional há pouco mais de 20 anos, tendo início apenas no momento em que a Psicologia Escolar passou a ser questionada em relação aos seus princípios epistemológicos e suas finalidades.

Tal movimento teve início com a tese de doutorado de Maria Helena Souza Patto, defendida em 1981 e publicada em 1984 no livro "Psicologia e Ideologia: uma introdução crítica à Psicologia Escolar". Além de desnudar as filiações teóricas e as práticas psicológicas em relação às explicações e ao tratamento dado às dificuldades escolares, a autora discutia a serviço de quem tais práticas estariam sendo desenvolvidas e concluía que a atuação dos serviços de Psicologia pouco contribuía para melhorar a qualidade da escola, principalmente das crianças de classes populares.

A parceria entre a Psicologia e a Educação brasileiras provém dos tempos em que as Escolas Normais buscavam pelo conhecimento da Psicologia para a compreensão dos processos de ensino e aprendizagem. Historicamente, esta parceria serviu, por muitas décadas, para referendar as incapacidades dos estudantes, pouco questionando a respeito dos princípios norteadores das políticas educacionais implementadas nas escolas de forma hierárquica, que contribuem para a produção do fracasso escolar (PATTO, 2005; SOUZA, 2006).

O trabalho de crítica construído no interior da própria Psicologia, bem como o movimento de democratização da sociedade brasileira, imprimiu transformações importantes na forma como tem estudado e enfrentado os problemas educacionais na sociedade brasileira. Deste modo, no campo da Psicologia Escolar e Educacional desloca-se o foco das pesquisas que antes analisavam o fracasso escolar, culpabilizando o aluno em termos de dislexia, transtorno de déficit de atenção e hiperatividade (TDAH), deficiência intelectual, imaturidade emocional, prontidão, ou responsabilizando sua família pela baixa condição socioeconômica, pais separados, família desestruturada, para a compreensão da instituição escolar como espaço constituído por contradições, conflitos, organizações, onde as políticas educacionais se materializam (BRASIL, 2013; SOUZA; ROCHA, 2011). 
Portanto, esse foco de investigação se propõe a realizar uma análise crítica dos estudos sobre as políticas públicas no campo educacional, a partir dos referenciais da Psicologia visando propor alternativas no âmbito da Educação Básica. Ao mesmo tempo, ao analisar contribuições que a Psicologia na interface com a Educação vem apresentando às políticas educacionais, sistematizar estas contribuições tornando-as visíveis aos profissionais da área e a todos os que militam em educação.

\section{METODOLOGIA}

Para identificação e análise das referidas produções de pesquisadores dos/nos programas de pósgraduação de Educação e de Psicologia em Mato Grosso do Sul, que tomaram como objeto de estudo as políticas educacionais na interface com a Psicologia, foi realizada pesquisa de abordagem qualitativa, por realizar uma aproximação fundamental entre sujeito e objeto, uma vez que ambos são da mesma natureza, as ações, as estruturas e as relações tornam-se significativas. Também por reconhecer em seus participantes sujeitos elaboradores de conhecimentos e produtores de práticas. É caracterizada, ainda, como bibliográfica, do tipo estado do conhecimento, de cunho documental.

Segundo Soares e Maciel (2000) a caracterização e a análise das condições de produção sobre determinado tema são demandas que se impõem no desenvolvimento histórico da ciência.

Assim, da mesma forma que a ciência se vai construindo ao longo do tempo, privilegiando ora um aspecto ora outro, ora uma metodologia ora outra, ora um referencial teórico ora outro, também a análise, em pesquisas de estado do conhecimento produzidas ao longo do tempo, deve ir sendo paralelamente construída, identificando e explicitando os caminhos da ciência, para que se revele o

processo de construção do conhecimento sobre determinado tema, para que se possa tentar a integração de resultados e, também, identificar duplicações, contradições e, sobretudo, lacunas, isto é, aspectos não estudados ou ainda precariamente estudados, metodologias de pesquisa pouco exploradas. (SOARES; MACIEL, 2000, p. 6).

As pesquisas em que se buscam realizar levantamentos sobre determinado campo do conhecimento humano, ganharam relevância nos últimos anos em função da abrangência dos estudos realizados tornando-se necessárias não só para reorientar os investimentos na área em estudo, mas principalmente para identificar as contribuições da pesquisa para o enfrentamento de desafios postos pelas condições educacionais do país (ROMANOWSKI; ENS, 2006).

Nesse sentido, os estudos que se propõem a mapear o estado do conhecimento em determinado campo, podem contribuir de maneira significativa para a "constituição do campo teórico de uma área de conhecimento" (ROMANOWSKI; ENS, 2006), uma vez que buscam identificar as contribuições para a elaboração teórica, as restrições sobre o campo em que se desenvolve a pesquisa, as lacunas em sua divulgação, as inovações que estão emergindo e, principalmente, as contribuições da pesquisa na proposição de alternativas para os problemas da prática.

\section{PERCURSO METODOLÓGICO}

Até o momento, foram pesquisadas as dissertações dos cursos de mestrado em Psicologia da Universidade Católica Dom Bosco (UCDB) e da Universidade Federal de Mato Grosso do Sul (UFMS), ambos funcionando na cidade de Campo Grande-MS, defendidas entre os anos de 2003 e 2016. Esses são os únicos cursos de Pós-graduação em Psicologia em funcionamento no Estado.

As buscas foram realizadas nos sites desses cursos, entre os meses de maio e julho de 2016, e foram inventariadas duzentas e vinte e nove dissertações. Dessas, foram selecionadas para análise vinte e cinco, que tomaram como objeto de estudo as políticas educacionais, perfazendo 10,92\% do total levantado.

Para facilitar as análises, as dissertações selecionadas foram agrupadas em seis eixos de análise, a saber:

a) Políticas intersetoriais. Integraram esse eixo trabalhos que investigaram e/ou discutiram as políticas que estabelecem interfaces entre a saúde, a educação e a assistência social, tais como trabalhos que tratem da saúde dos profissionais da educação, escolarização da infância em abrigos, adolescentes em conflito com a lei (socioeducação), educação em contextos domiciliar, hospitalar e prisional.

b) Políticas de melhoria da educação. Foram incluídos nesse eixo trabalhos que investigaram e/ou discutiram políticas (programas e projetos) que objetivam a melhoria da qualidade da educação, tanto em relação ao acesso e permanência quanto ao enfrentamento de problemas no processo de escolarização. 
Também trabalhos que discutem a organização e estruturação do sistema de ensino, incluindo o tempo previsto para educação obrigatória, infraestrutura.

c) Políticas de atendimento à diversidade. Eixo composto por trabalhos que investigaram e/ou discutiram as políticas de direitos humanos, educação do campo, na floresta, dos povos quilombolas, etnias indígenas, populações afrodescendentes e LGBT, e Educação de Jovens e Adultos e cotas nas universidades.

d) Políticas para educação inclusiva. Constituíram esse eixo trabalhos que investigaram e/ou discutiram a política de inclusão escolar, geral ou de um segmento específico (por exemplo surdos, altas habilidades e superdotação, deficiência intelectual, dentre outros) bem como atendimentos educacionais em geral.

e) Políticas de formação e atuação do psicólogo escolar. Participaram desse eixo trabalhos que investigaram e/ou discutiram políticas de formação, inserção e atuação de psicólogos escolares nos diversos níveis de educação.

f) Políticas de formação de professores. Eixo formado por trabalhos que investigaram e/ou discutiram a formação inicial e continuada de professores.

\section{RESULTADOS E DISCUSSÃO}

Apresenta-se abaixo (Quadro1) os percentuais de incidência das dissertações analisadas separados por eixos. Essa informação, embora não tenha a finalidade de definir a importância dos temas abordados por cada um dos eixos, já que todos possuem notória relevância, revela um desenho que ajudará a estabelecer diretrizes para as análises e discussões que seguirão.

Quadro 1 -Percentuais de incidência das dissertações por eixo de análise

\begin{tabular}{|l|c|c|}
\multicolumn{1}{|c|}{ Eixos de Análise } & Quantidade & Percentual \\
\hline Políticas intersetoriais & 7 & $44 \%$ \\
\hline Políticas de melhoria da educação & 3 & $28 \%$ \\
\hline Políticas de atendimento à diversidade & 2 & $12 \%$ \\
\hline Políticas para educação inclusiva & 1 & $8 \%$ \\
\hline Políticas de Formação e atuação do psicólogo escolar & 1 & $4 \%$ \\
\hline Políticas de formação de professores & 1 & $4 \%$ \\
\hline
\end{tabular}

Organizado pelas autoras, 2016.

Apresentamos a seguir os primeiros resultados do subprojeto "Análise das produções e projetos dos pesquisadores e das pesquisadoras dos programas e nos programas de pós-graduação de Educação e de Psicologia em Mato Grosso do Sul, que tomaram como objeto de estudo as políticas educacionais na interface das áreas da Educação e da Psicologia", discutindo o eixo de análise com maior incidência.

\section{POLÍTICAS INTERSETORIAIS: BREVE DISCUSSÃO}

Diante da incidência de pesquisas que discutem a questão da intersetorialidade nas políticas públicas, adveio a necessidade de refletir sobre a indispensabilidade de apoio dos diversos setores para garantir os direitos de acesso à educação pública de qualidade no Brasil, possibilitando a permanência e a conclusão dos níveis de ensino que a compõem.

A luta para garantir esse direito gerou a premência para a mobilização e articulação de diversas áreas e setores, redundando na necessidade de aproximações, interlocuções de seus saberes e a expansão de suas atuações, que passaram a compor as decisões do Poder Público, já que

No processo histórico-político em que se desenvolveu a democratização do ensino no Brasil, essa dimensão de luta permaneceu fortemente presente, culminando na conquista constitucional do direito subjetivo à educação pública gratuita de qualidade, com igualdade de condições para acesso e permanência na escola pública gerida por princípios democráticos. Esse fato assevera a exigência de aprimoramento dos arranjos institucionais para a garantia do direito promulgado. (OLIVEIRA, 2012, p.6). 
Pudemos perceber na análise da dissertação "Investigação da prevalência de ansiedade-traço-estado em professores do ensino fundamental e médio da rede estadual de Campo Grande/MS", de Ângela Benitez Martinez, as possibilidades de um trabalho em parceria, que pode ser desenvolvido com a presença de ações de psicólogos educacionais:

Enfim, sugestões podem ser feitas, no sentido de ajuda e orientação aos profissionais da área educacional, após se ter em mãos a análise dos dados como resultado desta pesquisa. Poderia ser uma orientação e promoção de saúde mental aos professores de Ensino Fundamental e Médio da rede estadual de Campo Grande, Mato Grosso do Sul. E não apenas a eles, que foram objetos maiores de nosso estudo, como também a todos os que participam da área educativa. (MARTINEZ, 1999, p.165).

Tais conclusões coadunam com o que escreveram Souza e Rocha (2008) acerca da importância do conhecimento das políticas, considerando os aspectos de sua confecção até sua consolidação, pelos psicólogos que atuam nas escolas:

Portanto, conhecer como as políticas são implantadas, as questões postas pelos educadores com relação às concepções e perspectivas e as condições de trabalho para sua implementação são fundamentais para que o psicólogo atue no campo da educação. (SOUZA; ROCHA, 2008, p.29).

0 trabalho do psicólogo junto à educação escolar exige dele uma imersão nesse universo, sendo considerado fundamental o seu conhecimento e o entendimento das especificidades oriundas de remédios legais corporificados nas políticas públicas voltadas à educação.

Nesse sentido, o Conselho Federal de Psicologia, assim como seus Conselhos Regionais já sinalizaram para a necessidade da realização desse trabalho conjunto, superando equívocos e preconceitos, em prol do sistema educacional brasileiro e do aperfeiçoamento profissional dessa categoria, entendendo que [...] é hora de construirmos e divulgarmos referências técnicas e políticas para a nossa atuação no campo escolar/educacional. Nosso aperfeiçoamento profissional depende de compreendermos a complexidade do sistema educacional brasileiro para atuarmos em prol da inclusão social de todos. (DELOU, 2008, p. 26).

Tal pensamento corrobora os estudos contidos na dissertação "Não iguala e ainda diferencia: as implicações do Programa de Apoio ao estudante da Universidade Federal de Mato Grosso do Sul na consciência dos acadêmicos", de autoria de Ana Lúcia Martins de Souza, que investigou estudantes que participaram do Programa de Apoio ao Estudante da Universidade Federal de Mato Grosso do Sul, pesquisando a influência de tal programa no desenvolvimento humano dos acadêmicos:

A pesquisa evidencia que o grupo compartilha dos significados sociais presentes em nossa sociedade, ainda que reproduzam valores ideológicos não compatíveis com sua origem de classe. Entretanto, ao reproduzirem conteúdos da ideologia dominante, principalmente relacionados à condição socioeconômica do grupo, não se dão conta de que essa condição não está determinada individualmente, sendo resultado das relações que se dão nesta sociedade capitalista. (SOUZA, 2014, p.7).

Colaborou, dessa forma, para que fosse percebida a maneira como esses alunos significam suas situações e de que forma entendem suas relações. Para as questões de aprendizagem, essas concepções acerca de si e a acerca do meio social em que os indivíduos estão inseridos, exercem influência determinante em sua evolução cognitiva, incidindo no desenvolvimento das funções psicológicas superiores ${ }^{5}$, eixo central dos postulados da Teoria Histórico-Cultural, que acontece a partir da articulação do que é interior e do que é exterior ao indivíduo. Dessa maneira, Vigotski (2000) explica que "falar sobre processo externo, significa falar social. Qualquer função psicológica superior foi externa - significa que ela foi social; antes de se tornar função, ela foi uma relação social entre duas pessoas" (VIGOTSKI, 2000, p. 24).

Nesse sentido, faz-se importante relembrar que a pedra fundamental da abordagem vigotskiana para estudo e interpretação das funções psicológicas superiores do ser humano, é a visão dialética de mundo, que embora admita a influência da natureza sobre o homem, declara que este, por sua vez, afeta a natureza e cria, por meio de suas mudanças nesta mesma natureza, novas condições para sua existência.

No âmbito educacional apresentado na dissertação de Souza (2014), cabe considerar, então, uma dialética histórica, compreendida a partir de determinantes históricos que incidem sobre a educação, não se limitando a estratégias revolucionárias imprecisas ou isoladas, mas que pressuponham que o ponto inicial para a compreensão da educação é a prática social, ao mesmo tempo que se torna ponto de chegada, tendo 
em vista a perspectiva de transformação social, de superação do senso comum. Ao mesmo tempo em que deve propor aos sujeitos nela envolvidos um conhecimento da realidade concreta, deve torná-los capazes de objetivar a transformação dessa realidade, atuando revolucionariamente.

A respeito de tal práxis educativa, Saviani (2008) afirma que "essa é a única maneira de convertê-la em instrumento que possibilite aos membros das camadas populares a passagem da condição de "classe em si" para a condição de "classe para si" (SAVIANI, 2008, p. 7).

0 mesmo autor indica o locus onde os movimentos de superação da ordem capitalista devem acontecer, afirmando que

A escola é, pois, compreendida com base no desenvolvimento histórico da sociedade; assim compreendida, torna-se possível a sua articulação com a superação da sociedade vigente em direção a uma sociedade sem classes [...]. É dessa forma que se articula a concepção política [...] com a pedagogia [...], que envolve a compreensão da realidade humana como sendo construída pelos próprios homens a partir do processo de trabalho, ou seja, da produção das condições materiais ao longo do tempo. (SAVIANI, 2008, p. 103).

Destaca-se, a partir desta afirmação, que a Psicologia e a Educação devem considerar a escola como instituição indissociável da sociedade, sendo uma extensão desta, com tendência a reproduzir, em maior ou menor grau, o corpo social como um todo. Gomes e Sanzovo (2013) confirmam que

A escola é um reflexo do meio social que a compõe. Embora ela conte com sua autonomia existencial, não há como deixar de reconhecer que ela não é uma ilha isolada do mundo; ela reproduz as características, modos, hábitos e regras culturais de suas respectivas comunidades. Sendo parte do todo, do contexto social, ela absorve o funcionamento da sociedade e o incorpora em seu universo escolar. (GOMES e SANZOVO, 2013, p. 56).

Patto $(1997,2004)$, ao expor ideia a respeito dessa relação, apontou que esta não pode se ocupar mais com teorias e práticas reprodutivas do status quo, sem considerar o papel social da escola na formação do cidadão. A autora descreveu no livro "A Produção do Fracasso Escolar" como a Psicologia e a Educação estão a serviço de uma ideologia que serve para excluir e estigmatizar os indivíduos e suas famílias, dividindo e classificando alunos entre os que aprendem e os que não aprendem, por exemplo. Essa divisão encontrava-se predominantemente baseada na divisão de classes.

Finalmente, faz-se necessário considerar que na visão da Teoria Histórico-Cultural a escola constitui-se um espaço privilegiado para que o ser humano se aproprie das conquistas das gerações precedentes, na medida em que nela se conta com o amparo e o auxílio de membros mais experientes da cultura, na difícil empreitada de construir uma visão própria e crítica do real.

\section{CONCLUSÕES POSSÍVEIS}

Existe um conjunto de políticas públicas que assumem o compromisso de garantir o desenvolvimento educacional de crianças e adolescentes. Contudo, apesar desse conjunto, as avaliações nacionais têm apontado para o não alcance dos patamares desejáveis das escolas públicas brasileiras. 0 que indica a complexidade de efetivação dos direitos, dos acessos e da consolidação de uma educação de qualidade no País.

O presente artigo, com objetivo de identificar e analisar produções e projetos de pesquisadores dos/nos programas de pós-graduação de Educação e de Psicologia em Mato Grosso do Sul, que tomaram como objeto de estudo as políticas educacionais na interface com a Psicologia, o fez de forma frugal, mas sem perder de vista a importância desta inter-relação e dos caminhos científicos que podem subsidiar as análises crítico-reflexivas das temáticas a ela pertinentes.

Com destaque à articulação de diferentes setores e/ou políticas que dão condição à integração entre eixos e trabalhos que investigaram e/ou discutiram as políticas que estabelecem interfaces entre diversas temáticas e necessidades, optou-se por voltar-se às políticas intersetoriais, e estas entendidas como ações articuladas de diversos setores, programas, ministérios, entre outros, que objetivam efetivar a educação de crianças, adolescentes e jovens brasileiros.

A pesquisa a respeito de temáticas que se articulam, mas que nem sempre se mantêm vinculadas, inova na tentativa de superação da fragmentação de ações e procedimentos em pesquisas e práticas educacionais e 
sociais. Organizar dados e analisar programas e ações de alta relevância para a Educação podem oferecer contribuições para conhecimento e estruturação de políticas e práticas sociais, educacionais e culturais para essas duas áreas - Educação e Psicologia - e para o desenvolvimento de ações mais inovadoras.

Vê-se que a interface entre Psicologia e Educação exige conhecimento das necessidades dos sujeitos, no que se refere aos processos educacionais, não importando o contexto, as condições sociais ou políticas em que estejam inseridas (ricas, pobres, capacitadas, deficientes, abandonadas ou acolhidas por suas famílias).

Esta interface deve buscar defender os direitos do indivíduo no atendimento de suas necessidades educacionais e promover seu desenvolvimento, sem discriminação ou intolerância de qualquer tipo ou grau, tendo o cuidado de não reproduzir formas de dominação. Neste sentido, é preciso que se encontre tanto inserida no contexto no qual esses processos ocorrem quanto conheça aspectos históricos, econômicos, políticos e culturais da população e da comunidade que atende (DIAS et al, 2014).

É certo que as questões abordadas neste estudo requerem aprofundamento, contudo espera-se que as considerações aqui apresentadas instiguem novos questionamentos e novas pesquisas.

\section{REFERÊNCIAS}

[1] Brasil. Conselho Federal de Psicologia. Referências técnicas para atuação de psicólogas (os) na Educação Básica. Brasília: CFP, 2013.

[2] Delou, C. M. C. Psicologia, Políticas Públicas Intersetoriais e Educação Inclusiva. In: Ano da Psicologia na Educação: textos geradores. Conselho Federal de Psicologia. 2008. Disponível em: <http://site.cfp.org.br/wpcontent/uploads/2008/08/ano-educacao.pdf> Acesso em 10 ago. 2016.

[3] Dias, A.C.G. et al. Psicologia Escolar e possibilidades na atuação do psicólogo: algumas reflexões. Revista Quadrimestral da Associação Brasileira de Psicologia Escolar e Educacional. São Paulo-SP, v. 18, n. 1, janeiro/abril de 2014: 105-111.

[4] Gomes, L. F.; Sanzovo, N. M. Bullying e prevenção da violência nas escolas. Quebrando mitos, construindo verdades. São Paulo: Saraiva, 2013.

[5] Martinez, A. B. Investigação da prevalência de ansiedade-traço-estado em professores do ensino fundamental e médio da rede estadual de Campo Grande / MS. Campo Grande, 1999. 177p. Dissertação (mestrado) Programa de Mestrado em Psicologia.Universidade Católica Dom Bosco (UCDB).

[6] Oliveira, R. C. Intersetorialidade entre as políticas públicas e seus efeitos na escola pública brasileira. In: Congresso Internacional de Pedagogia Social, 4., 2012, São Paulo. Proceedings online... Associação Brasileira de Educadores Sociais, Disponível em: $<$ http://www.proceedings.scielo.br/scielo.php?script=sci_arttext\&pid=MSC0000000092012000200024\&lng=en\&nr $\mathrm{m}=\mathrm{abn}>$. Acesso em: 9 Ago. 2016.

[7] Patto, M. H. S. (Org). Introdução à Psicologia Escolar. São Paulo: Casa do Psicólogo,1997.

[8] _ _ A Produção do Fracasso Escolar. São Paulo: Casa do Psicólogo, 2004.

[9] _. Exercícios de Indignação: escritos de Educação e Psicologia. 2ª Ed. São Paulo: Casa do Psicólogo, 2005.

[10] Romanowski, J. P.; Ens, R. T. As pesquisas denominadas do tipo “Estado da Arte” e, educação. Revista Diálogo Educacional, v. 6, n. 19, p. 37-50, set., 2006.

[11] Santos. L. M. O processo de readaptação: o sentido conferido pelos professores. Campo Grande. 2015. 136p. Dissertação (mestrado). Curso de Pós-graduação em Psicologia, da Universidade Federal de Mato Grosso do Sul (UFMS).

[12] Saviani, D. Escola e Democracia. 40 ed. Campinas: Autores Associados, 2008.

[13] Soares, M. B.; Maciel, F. Alfabetização. Brasília: MEC/INEP/Comped, 2000.

[14] Souza, A. L. M. Não iguala e ainda diferencia: as implicações do Programa de Apoio ao estudante da Universidade Federal de Mato Grosso do Sul na consciência dos acadêmicos. 2014. 175p. Dissertação (mestrado). Curso de Pós-graduação em Psicologia, da Universidade Federal de Mato Grosso do Sul (UFMS).

[15] Souza, M. P. R. de. Políticas Públicas e Educação: desafios, dilemas e possibilidades. In. VIÉGAS, L. de S.; Angelucci, C. B. (Orgs.) Políticas Públicas em Educação: uma análise crítica a partir da Psicologia Escolar. São Paulo: Casa do Psicólogo, p. 229-243, 2011. 
[16] _ _ Políticas Públicas e Educação: desafios, dilemas e possibilidades. In: Viégas, L. S.; Angelucci, C. B. (Orgs.). Políticas Públicas em Educação: uma análise crítica a partir da Psicologia Escolar. São Paulo: Casa do Psicólogo, p. 229-243, 2006.

[17] Souza, M. P. R. S.; Rocha, M. L. Políticas educacionais: legislação, formação profissional e participação democrática. In: Facci, M. G. D.; Meira, M. E. M.; Tuleski, S. C. A exclusão dos incluídos: uma crítica da Psicologia da Educação à patologização e medicalização dos processos educativos. Maringá: Eduem, p. 345-370, 2011.

[18] __. Políticas Educacionais: legislação, formação profissional e participação democrática. In: Ano da Psicologia na Educação: textos geradores. Conselho Federal de Psicologia. 2008. Disponível em: <http://site.cfp.org.br/wp-content/uploads/2008/08/ano-educacao.pdf>Acesso em 8 ago. 2016.

[19] Vigotski, L. S. Manuscritos de 1929. Educação Socialista. Campinas, v. 21, n. 71, p. 21-44, jul. 2000 . Disponível em: $\quad$ http://www.scielo.br/scielo.php?script=sci_arttext\&pid=S010173302000000200002\&lng= en\&nrm=iso $>$. Acesso em: 01 mar. 2016. 


\section{Capítulo 5}

Mecanismos de construção da gestão democrática: Um estudo em três escolas municipais na cidade de São Luís - MA

\section{Katana de Fátima Diniz Boaes}

Resumo: 0 objetivo deste artigo foi investigar as práticas de gestão em três escolas do município de São Luís do Maranhão e suas possíveis relações com o desempenho escolar. A pesquisa aqui desenvolvida visou ressaltar que para os gestores, professores e pais de alunos não é suficiente apenas desenvolver saberes e competências dentro da sala de aula, é preciso que compreendam como e porque são tomadas certas decisões no sistema de ensino; quais relações de poder há nessas decisões, e quais as implicações positivas e negativas das decisões tomadas. 0 trabalho foi desenvolvido por meio de pesquisa bibliográfica utilizando os estudos de Bobbio (2000), Cury (1987), Dourado (2007), Lucky (2009, 2011), Padilha (1998), Paro (1997, 2010), Silva (2012) e Souza (2006), documental exploratória e levantamento de dados empíricos com realização de questionários e entrevistas semi- estruturadas com gestores, professores e pais de alunos das referidas escolas. Os dados empíricos evidenciaram que as gestoras das três escolas pesquisadas, ao se depararem com o baixo desempenho, mau comportamento, repetência, bem como o desinteresse nas aulas, usavam de sua autonomia para convocar reuniões com os professores, bem como, acionarem o Conselho Escolar vigente buscando estratégias para reverter este cenário. Verificou-se que as gestoras de duas escolas apresentaram posturas consideradas democráticas, permitindo a ação de toda sua equipe, aceitando e buscando estratégias variadas, ouvindo pais, professores e alunos; enquanto que em outra escola a diretora fazia uso de uma postura mais centralizadora. Constatou-se ainda a importância da união de pais, professores e gestores em prol da educação de seus filhos e alunos. Na medida em que todos se empenham buscando melhorias, os problemas são atenuados e, por vezes, sanados.

Palavras-chave: Gestão democrática. Desempenho escolar. Educação básica. 


\section{INTRODUÇÃO}

A prefeitura de São Luís, em 2013, se viu diante de uma nova força política representada por um jovem de 35 anos, a "Ilha de Upaon Açu" 6 elegeu o prefeito o Sr. Edivaldo Holanda Junior, que filiado ao Partido Democrático Trabalhista (PDT), prometeu uma gestão marcada pela democratização do acesso e da gestão de serviços públicos para contrapor ao histórico de corrupção e centralização das decisões político-administrativas que marca a história do Maranhão pela oligarquia Sarney.

No bojo dessas promessas de reforma da educação, elaborou-se uma série de projetos que se colocaram com o escopo de transformar as unidades de ensino de São Luís sob a perspectiva de possíveis caminhos na construção da gestão escolar democrática. Entretanto, verifica-se que até agora quase nada foi feito.

São Luís possui uma quantidade considerada de escolas públicas e particulares. Dados de 2012, do Instituto Brasileiro de Geografia e Estatística (IBGE), mostram que a cidade possui 474 escolas de ensino fundamental e 133 instituições de ensino médio, um total de 607 instituições de ensino. Deste total, 248 escolas fazem parte da rede municipal de educação. 0 último censo realizado pela Secretaria Municipal de Educação (SEMED) em abril de 2014, totalizou 83.790 alunos matriculados, destes 69.329 no ensino fundamental e 14.461 na educação infantil (SEMED, 2011).

No presente artigo, que é um recorte epistemológico da dissertação de mestrado da autora, tivemos por objetivo, portanto, investigar as práticas de gestão em três escolas do município de São Luís e suas possíveis relações com o desempenho escolar, com o fulcro em perceber se de fato as características básicas de uma gestão democrática contribuem ou não para um melhor desempenho dos alunos.

Para cumprir o nosso propósito neste estudo, definimos como questão de pesquisa: Como a gestão contribui ou não para o desempenho escolar?

Este estudo apresentou duas etapas em sua estrutura: a bibliográfica e a empírica. A pesquisa bibliográfica teve a finalidade de estabelecer o referencial teórico que subsidia e dá suporte à pesquisa de campo. Compreende-se a investigação das seguintes categorias teóricas: políticas públicas e gestão democrática. A segunda etapa, a pesquisa empírica, analisou a experiência que envolve a Secretaria de Municipal de Educação de São Luís, práticas de gestão em três escolas públicas do ensino fundamental de São Luís/MA, com resultados acima e abaixo da meta do Índice de Desenvolvimento da Educação Básica (IDEB) de 2011.

\section{GESTÃO DEMOCRÁTICA: LIMITES E POSSIBILIDADES}

A partir da última década do século $\mathrm{XX}$, fortaleceu-se uma tendência mundial à formulação de propostas que favorecessem o desenvolvimento da gestão educacional. São recorrentes os apelos para a eficiência e a eficácia do sistema educacional e, particularmente, da escola. As instituições públicas foram incentivadas a trilhar novos caminhos organizacionais na linha da autogestão, e os seus professores a participar de atividades que não se limitassem à sala de aula, mas que se destinem à própria organização da escola como um todo (FONSECA; OLIVEIRA; TOSCHI, 2004).

A discussão acerca da possibilidade de uma maior participação da comunidade escolar nos trâmites de gestão da unidade escolar pública brasileira, no âmbito da educação básica, é um processo relativamente novo, tendo acontecido basicamente a partir dos anos de 1980. Ainda que isso não nos permita dizer que anteriormente não tenham ocorrido movimentos no sentido de uma gestão escolar mais democrática, entretanto, é a partir desse período que tal processo se instala de maneira mais significativa.

A democratização da educação representou no processo de abertura política do país pós-ditadura militar, como componente central do novo reordenamento normativo e institucional no campo educacional. A gestão democrática foi incluída como princípio na Constituição brasileira de 1988 e passa a fazer parte da legislação, tanto no âmbito dos estados quanto dos municípios (CURY, 1987).

Um dos grandes problemas da educação no Brasil é a qualidade do ensino. Hoje, esse assunto está em pauta em todas as esferas governamentais e muito tem sido debatido com base nas publicações dos

\footnotetext{
${ }^{1} 60$ nome Upaon-Açu foi dado pelos tupinambás e significa "ilha grande.
} 
resultados das avaliações externas em larga escala, em especial a do IDEB, pautadas no rendimento do aluno, no desempenho dos sistemas escolares e na sua gestão (SILVA, 2012).

Dourado (2007) destaca que a busca da melhoria da qualidade da educação não está atrelada apenas ao ingresso e permanência do educando na escola, mas também a ações que possam mudar a situação de baixa qualidade na educação básica. Considera ser necessário reconhecer e identificar os condicionantes da política de gestão e pensar sobre a composição de estratégias de mudança que devem estar mediadas pelo regime de colaboração entre União, Estados, Distrito Federal e Municípios.

Para Lück (2009, p.69), a "escola democrática é aquela em que seus participantes estão coletivamente organizados e compromissados com a promoção de educação de qualidade para todos". Neste contexto, a escola democrática se preocupa com a participação de todos no processo de desenvolvimento da escola. Ato contínuo, no Brasil, atualmente, muito se fala em gestão democrática. A democracia, porém, não se constrói apenas com discurso e sim mediante articulação entre direitos e deveres, necessitando de ações e de práticas que possam fortificá-la.

Essa autora ainda argumenta que pensar a gestão democrática da educação é refletir sobre um conjunto de elementos implicados entre si (democratização do acesso, permanência na escola, democratização do saber, participação nos processos de decisão, relações de autonomia) e sua inserção em um projeto mais amplo de democratização da sociedade (LÜCK, 2011). Inicia-se, assim, um processo que envolve construção, elaboração, discussão, concepção e fundamentação; um processo que requer uma administração disposta realmente a utilizar, de forma racional, os recursos para fins determinados, e que proporcione à comunidade escolar a participação como verdadeiro exercício democrático.

Paro (2010) alerta, em consonância com Lück, para a necessidade da participação efetiva da comunidade nos processos deliberativos, pois quando há restrição de participação às pessoas que atuam no âmbito do Estado, a gestão escolar resume-se em mero arranjo entre funcionários públicos para o atendimento de interesses corporativos, que, via de regra, não coincidem com os interesses da população. Esse autor ainda aponta a importância dessa gestão participativa na escola para a superação da democracia liberal que por reduzir a participação às eleições, acaba servindo aos interesses de grupos minoritários e elites políticas, em detrimento das necessidades da maioria da população.

Padilha (1998) destaca que a tão sonhada escola democrática está diretamente ligada a escolha do diretor. Atualmente, no Brasil, a seleção do diretor ocorre, de forma geral, por meio de nomeação pelo poder público. Tal prática dificilmente é aceita como democrática, ainda que associada ou precedida de lista de candidatos indicada pela comunidade escolar. 0 autor também sinaliza que esse processo pode ser realizado por concurso público, por meio de provas e/ou títulos, a fim de evitar a influência do poder executivo.

Segundo Paro (1997), dentro do contexto de políticas educacionais que objetivam a constituição da escola como unidade dotada de autonomia, a forma como é escolhido o diretor, por indicação política, por concurso, por eleição ou por esquemas mistos, influencia de modo relevante o estilo mais ou menos democrático que assumirá a gestão do diretor, a sua maior ou menor aceitação pelo grupo e os interesses com os quais estará comprometido.

Dourado (2007) argumenta que a administração escolar, por não se resumir à dimensão técnica, mas por configurar-se em ato político, deve contemplar a participação da comunidade. Mesmo assim, alerta que a eleição, enquanto canal legítimo na luta pela democratização da escola, tem suas limitações ligadas ao sistema representativo.

Nesse sentido, a participação democrática pressupõe uma ação reguladora, fiscalizadora e avaliadora, além, é claro, de decisória sobre os rumos da vida política e social das instituições escolares e da sociedade. Mas esta participação só será de fato efetiva quando as pessoas que são chamadas a participar forem colocadas em condições adequadas para tal (BOBBIO, 2000).

Há certamente muitos obstáculos que devem ser enfrentados com o intuito de se construir uma gestão democrática nas escolas públicas municipais e estaduais. Entretanto, há iniciativas que devem ser estimuladas, como também a prática reflexiva para se encontrar caminhos mais promissores, capazes de romper com as barreiras administrativas e os vícios centralizadores dos órgãos públicos.

Na discussão da gestão como instrumento de construção de uma escola de qualidade, Coleman (1966) destacou-se como pioneiro num estudo em que buscou analisar os fatores intra e extraescolares voltados para a eficácia escolar. Tal autor tratou da desigualdade de oportunidades educacionais 
surgidas por meio de uma recomendação da Lei de Direitos Civis de 1964. No Brasil, a abordagem do desempenho escolar se deu no início da década de 1970 pautada em fatores externos, aqueles advindos fora do ambiente escolar.

Na compreensão de Souza (2006), uma boa escola requer a presença de professores, coordenadores e diretores com uma boa formação e comprometidos com a aprendizagem dos alunos, um projeto político e pedagógico construído com a participação de toda comunidade escolar, infraestrutura adequada e outros elementos. Dentre esses fatores que têm uma influência marcante no desempenho da escola está a gestão, que deve contar para o bom exercício de suas funções com o apoio de toda comunidade escolar. Esse autor ainda enfatiza a eficácia como meta para a escola e a importância da liderança do gestor como fatores fundamentais para o bom desempenho escolar.

Como se pode observar pelas considerações aqui tecidas, a questão da gestão escolar afeta não só a escola, mas a dinâmica dos sistemas de ensino. Por isso, faz-se necessário apresentar a problemática principal desta pesquisa, que consiste em saber se a gestão possibilita ou não um melhor desempenho escolar.

\section{METODOLOGIA}

A pesquisa aqui apresentada foi realizada a partir de procedimentos de métodos qualitativos, uma vez que se propôs a "[...] investigar o que ocorreu nos grupos e instituições relacionando as ações humanas com a cultura e as estruturas sociais e políticas, tentando compreender como as redes de poder foram produzidas, mediadas e transformadas" (ALVES- MAZZOTTI; GEWANDZJDER, 2004, p. 139).

Sendo este estudo um recorte epistemológico da dissertação de mestrado da autora, que foi realizada em três fases: a primeira de caráter exploratório, levantamento documental em torno de referências acadêmicas e legislativas (federal, estadual e municipal) sobre as temáticas políticas educacionais e gestão. A segunda fase foi a pesquisa de campo, apoiada na coleta de dados via questionários e entrevistas semi-estruturadas. Por último, foi realizada a análise dos dados, discussões dos resultados e culminando com a conclusão da pesquisa. Em breves relatos estes momentos são destacados.

\section{PESQUISA DE CAMPO E PROJETO POLÍTICO PEDAGÓGICO}

Como campo de pesquisa de dados coletados, foram selecionadas três escolas da rede de ensino público municipal de São Luís/MA que atendem ao Ensino Fundamental e que obtiveram os dois melhores e o pior resultado no IDEB entre todas as escolas da rede municipal em 2011. Destacamos que duas escolas estão localizadas em bairros com alto índice de violência e criminalidade dentro da grande São Luís na Zona Urbana, e apenas uma está localizada na Zona Rural, esta por sua vez fica localizada nas proximidades da Unidade Prisional de Pedrinhas.

Ao adentrar os muros da escola buscou-se compreender o seu funcionamento como um todo, tanto por meio de documentos que a orientam, quanto pelas falas dos sujeitos que a constituem, através do estudo do Regimento Interno da Rede Municipal, Projeto Político- Pedagógico (PPP), dos Estatutos, Atas dos Conselhos Escolares, bem como dos questionários e entrevistas realizadas com os gestores, professores e pais de alunos.

Foram observadas todas as instalações das escolas bem como sua estrutura física (salas de aula, quadra de esportes, laboratório de informática, biblioteca, banheiros, depósitos, cozinha, pátio, cantina, equipamentos, conservação, limpeza), seguindo um roteiro de observação.

O PPP das escolas bem como seus Conselhos Escolares constituem-se em dois instrumentos, materializados no contexto escolar, cujos objetivos, entre outros, são explicitarem os caminhos da escola no desenvolvimento de suas ações, no sentido de promover a participação da comunidade na gestão escolar. Entretanto a realidade que se apresenta em algumas Instituições de Ensino (a exemplo da escola C pesquisada) se contrapõe aos movimentos de democratização iniciados na década de 1980.

Nesse sentido consideramos os PPP das escolas como sendo um instrumento teórico- metodológico, ou seja, um referencial orientador das práticas educativas e administrativas, com o objetivo de enfrentar os desafios no dia-a-dia da escola, por meio de ações intencionais com o compromisso definido coletivamente de forma sistemática e participativa.

Nas escolas não é apenas o PPP na sua forma de registro documental que trata da sua relevância para o 
desenvolvimento das atividades inerentes à gestão escolar. Gestores, professores, muito mais que os pais, possuem uma concepção formada sobre o PPP, foi o que observamos nas entrevistas de campo. Observamos também um maior interesse e envolvimento quando abordamos as questões relacionadas ao Conselho Escolar, tanto por parte dos gestores, professores e pais de alunos.

Por esse motivo, dentre os mecanismos que norteiam a construção da gestão democrática (autonomia de gestão financeira, PPP, conselhos de classe, eleição para diretores, grêmios estudantis, associação de pais e CME) escolhemos nos aprofundar nos Conselhos de Classe por considerarmos a participação dos professores, pais e alunos mais representativa para o estudo em questão.

\section{OS CONSELHOS DE CLASSE}

Os Conselhos de Classe, em suma, constituem um exercício participativo que oferece as condições para os sujeitos se sentirem cada vez mais preparados para fazerem parte do processo de discussão da realidade em que a escola está inserida. Para tanto, no ato de tomar uma decisão, os membros do conselho escolar (CE) ou Conselho de Classe devem sempre saber fazer a diferença entre aquilo que serve para atender interesses particulares e individuais daquilo que deveria ser de interesse coletivo de todos os segmentos representados democraticamente no conselho.

Observamos nas três escolas pesquisadas a existência do conselho escolar ou de classe, estes por sua vez, possuem seus estatutos. Pudemos perceber também que a redação dos estatutos é a mesma nas três escolas, o que demonstra um consenso de opiniões.

No caso das escolas estudadas, os respectivos Conselhos Escolares foram eleitos da seguinte forma: Escola A - A diretora convocou uma grande reunião entre toda equipe escolar, pais e alunos para sensibilizar da importância do CE. Fez a leitura do estatuto do CE. e deixou aberto para quem quisesse participar. Os professores, bem como os pais e alunos, logo demonstraram interesse e se candidataram. Foi feito primeiro a votação entre os professores, seguidos de pais e alunos de forma democrática.

Nesse sentido de sensibilização, devemos fortalecer os instrumentos de participação no sentido de que a população deixe de ser somente beneficiária das políticas públicas, mas que tenha presença ativa na definição, elaboração, execução e acompanhamento dos serviços públicos. Segundo Gadotti (2010), para que a população participe é preciso oferecer as condições. O autor ainda pontua que "costuma-se convocar a população para participar em horários inadequados, locais desconfortáveis, dificuldades de acesso, etc., sem nenhum cuidado prévio. A população precisa sentir prazer em exercer os seus direitos" (GADOTTI, 2010, p. 48).

Em direção contrária a esse autor (GADOTTI, 2010), a diretora da escola B buscou estratégias para atrair um maior número de pais as reuniões. Escola B: A diretora convocou uma assembléia na quadra coberta entre toda equipe da escola (dos dois turnos), numa manhã de sábado. Como atrativo para chamar um maior número de pessoas, ofereceu um café da manhã ao final da reunião. Fez a leitura do estatuto e logo perguntou quem tinha interesse de compor o CE. Um dos pais perguntou se eles receberiam salário para ocupar aquela função.

Escola C: A diretora tentou por duas vezes marcar uma reunião para conversar com professores, pais e alunos sobre o CE. Na primeira reunião marcada, só compareceram os professores do turno que estavam na escola, alguns alunos e poucos pais. Marcou-se uma segunda reunião para sábado, sendo assim possível sua realização, comparecendo todos os professores e um grande número de pais e alunos.

Consideramos que o processo de gestão democrática da escola pública se insere no contexto mais amplo de luta pela democratização da sociedade, portanto, essa temática embora importante para a comunidade escolar, ainda é uma realidade distante para alguns estabelecimentos, pois a escola ainda se encontra distante da cultura participativa, ressente-se da frágil organização do conselho escolar e da pouca participação dos professores, alunos e pais nos espaços de decisões coletivas.

Foram ainda encontradas práticas participativas tuteladas, sobretudo no que se refere aos conselhos escolares, que às vezes se dizem democráticos, mas que na prática se configuram como instrumentos de centralização de poder e são utilizados como mecanismos para operacionalizar objetivos prédefinidos pelos dirigentes das unidades escolares e pelas secretarias de educação.

Gadotti (2010, p.48-49) ainda argumenta que é necessário que os resultados sejam concretos e se traduzam em resultados, pois "Na nossa tradição política a participação se tornou instrumento de manipulação em fastidiosas e intermináveis reuniões ou assembléias em que, muitas das vezes, a única 
decisão consiste em marcar uma próxima reunião".

Os membros dos conselhos foram eleitos nas escolas A e B de forma democrática entre os presentes nas reuniões, somente a escola $C$ fez uso de indicação dos membros representados por pais e filhos, tendo em vista o pouco entusiasmo por parte dos mesmos.

Na visão da gestora da escola A, o conselho escolar é composto por todos os segmentos da escola e da comunidade. Não há dúvidas de que o CE é uma instância de democracia da gestão. A gestora da escola B reitera tudo o que está escrito no estatuto e acrescenta que o CE existe para juntos decidirem sobre o futuro da escola e dos alunos. Por último, a gestora da escola $\mathrm{C}$ reclama, faz críticas e discorda da obrigação de ter que realizar eleição para compor o CE. Na sua visão, professores, pais e alunos deveriam ser escolhidos de acordo com disponibilidade de tempo e interesse em participar das decisões da escola.

Compreendemos que para a construção de uma gestão democrática na escola e, para que a descentralização e a autonomia não sejam apenas prescrições legais é necessário rom- permos com as estruturas burocráticas, centralizadas e verticalizadas dos órgãos que planejam e executam as políticas de educação, ou seja, é preciso "uma profunda alteração dos organis- mos ligados à educação: federais, estaduais e municipais" (SPOSITO, 2002, p. 50).

Geralmente, os pais são chamados a participarem dos conselhos escolares, somente para o cumprimento das determinações legais, sobretudo, para referendarem os gastos financeiros dos recursos que são descentralizados para as unidades escolares.

Observamos nas falas dos pais acerca dos CE comentários importantes, onde destacamos; "quase todas as reuniões eram para prestação de contas, e para colher nossas assinaturas. Na maioria das vezes, era isso. Mas decidimos muitas coisas também, sobre compra de materiais", relatou o pai da escola A. Já o pai da escola B, salientou a importância de ser ouvido, bem como, dar a sua opinião. E ainda, que muitas coisas boas já decidiram juntos. A resposta considerada mais impactante, veio do pai da escola C, classificando as reuniões dos conselhos de "chatas". Reclamou que, por vezes, perdia a manhã toda na escola e nada era resolvido. Por esse motivo, foi se ausentando das reuniões.

O depoimento do pai da escola C coaduna-se com a análise de Gohn $(2008$, p.106), que evidencia "a existência de colegiados manipulados por diretoras (es) despóticas (os), conselhos formados para legitimar os interesses da administração da escola. Ou seja, conselhos democráticos, cidadãos participativos, com força política, são raros e exceções".

Segundo Santos (2005), o aspecto principal da existência do CE é voltado para questões de ordem financeira, ou seja, para que os membros assinem as atas referentes às prestações de conta dos recursos do Programa Dinheiro Direto na Escola (PDDE), e, desta forma, confirmem a execução das compras de materiais e/ou serviços. Portanto, nesse caso o CE serve apenas para homologar as decisões e não discuti-las. Nesse aspecto, o CE perde a sua função de instância consultiva, deliberativa e normativa, e sua importância fica diluída.

Entre os representantes dos pais, percebe-se, segundo seus próprios relatos, que existe interesse em participar das reuniões do CE e também da gestão da escola. Mas, por falta de tempo, muitas vezes se ausentam das reuniões. 0 representante dos pais da escola C, citado acima, não compreende a importância de sua participação nas reuniões do CE. Os demais pais membros relataram que participam das reuniões sempre que chamados, principalmente quando elas são marcadas com antecedência e de preferência aos sábados. Mas reconhecem que, por vezes, faltam por motivos de saúde ou por motivos alheios a sua vontade.

Já os professores entrevistados foram unânimes em responder que participam das reuniões por entenderem que é importante para a escola e para juntos decidirmos de forma democrática, o que de fato pode ser melhor para nossa escola. Por meio das falas dos docentes podemos observar que todas têm consciência do papel que ocupam como membros dos CE.

Todos os acontecimentos relatados pelas gestoras, professoras, pais de alunos acerca do CE revelam que as práticas instituídas nas escolas pesquisadas se configuram como gestão democrática, com exceção da escola $\mathrm{C}$, onde percebemos a figura da gestora como sendo o centro das decisões, tendo controle sobre todas as ações realizadas dentro da escola.

Segundo Paro (2002, p 81-82), esta situação é comum porque o que acontece atualmente é que o "diretor, como responsável último pela escola, que tem de prestar contas de tudo diante do Estado, fica temeroso de que as coisas saiam de seu controle, e ele acaba respondendo por medidas, tomadas por 
outros, que ele considera impróprias". Por essa razão, observamos essa tendência de centralização, na gestão de alguns diretores, a exemplo da escola C.

Não podemos reduzir a participação efetiva somente à existência de processos formativos que, embora seja um ponto importante, e por si só, não garantirá práticas demo- cráticas, autônomas e participativas, pois devemos ter claro que os conselhos não reduzem as tensões entre escola e a comunidade. No espaço escolar, o conselho deve oferecer condições de aprendizagem para os membros da comunidade escolar e para a comunidade de um modo geral. Entretanto, ele não se constitui no único instrumento da gestão, mas é um passo importante e necessário para autonomia da escola.

As argumentações apresentadas por todos os envolvidos servem de reflexão acerca das condições em que ocorre a participação deste segmento. Por tudo o que foi relatado, muita coisa ainda precisa ser feita para se construir uma escola democrática. A grande maioria dos entrevistados tem consciência que a melhoria da qualidade do ensino e do bom desempenho dos alunos, não é uma tarefa isolada, de uma pessoa só, mas de toda a comunidade que participa de forma direta ou indireta deste processo.

\section{CONSIDERAÇõES FINAIS}

Este estudo procurou mostrar quais os fatores influenciaram o bom desempenho dos alunos a partir de ações implementadas pelos gestores de três escolas municipais na cidade de São Luís. Tais ações geraram resultados distintos no desempenho desses alunos, a partir de reflexões sobre os dados levantados na análise documental e nas entrevistas com os atores envolvidos.

Os dados empíricos levantados na pesquisa de campo evidenciaram que as gestoras das três escolas pesquisadas, ao se depararem com o baixo desempenho, mau comportamento, repetência, bem como o desinteresse nas aulas, usavam de sua autonomia para convocar reuniões com os professores, bem como, acionarem o Conselho Escolar vigente buscando estratégias para reverter este cenário.

Assim sendo, para responderem à questão suscitada, se existia algum mecanismo voltado para a melhoria do desempenho escolar dos alunos, pode-se constatar que cada escola pesquisada buscou caminhos próprios em busca dessa melhoria. As gestoras das Escolas A e B apresentaram posturas consideradas democráticas, permitindo a ação de toda sua equipe, aceitaram e buscaram estratégias variadas, ouvindo pais, professores e alunos. Ao passo que a gestora da Escola C, utilizando uma postura mais centralizadora e por vezes engessada, pouco contribuiu com suas ações para esta melhoria.

Constatamos, a importância de estarem todos juntos, pais, professores e gestores unidos em prol da educação de seus filhos e alunos. Na medida em que todos se empenham buscando melhorias, os problemas são atenuados e, por vezes, sanados.

Podemos afirmar, com os fatos verificados, que a gestão democrática e participativa é um dos caminhos para se obter sucesso na escola e consequentemente contribuir para um bom rendimento e desempenho dos alunos, levando-se em consideração que toda mudança gera rupturas de concepções e valores até então concebidos, mas sempre se abrem novos caminhos para uma gestão mais eficaz.

\section{REFERÊNCIAS}

[1] Alves-Mazzotti, A J.; Gewandsznajder, F. Método nas Ciências Naturais e Sociais: Pesquisa Quantitativa e Qualitativa. São Paulo: Pioneira, 2004.

[2] Bobbio, N. Estado, Governo, Sociedade: Para uma teoria geral da política. 4. ed. Rio de Janeiro: Paz e Terra, 2000.

[3] Coleman, J. S. et al. Equality of Educational Opportunity. Washington: Office of Education/US Department of Health, Education, and Welfare, 1966.

[4] Cury, C. Educação e contradição: elementos metodológicos para uma teoria crítica do fenômeno educativo. 3. ed. São Paulo: Cortez; Autores Associados, 1987.

[5] Dourado, Luiz Fernandes. Políticas e gestão da educação básica no Brasil: limites e perspectivas. Educação e Sociedade. v. 28, n.100. Campinas, SP: Cedes, 2007.

[6] Fonseca, M; Oliveira, J. F. ; Toschi, M. S. As tendências na atual política educacional brasileira: autonomia ou controle? In: Bittar, M.; Oliveira, J.F. Gestão e Política da educação. Rio de Janeiro: DP\&A, 2004.

[7] Gadotti. M. Autonomia da Escola princípios e propostas. São Paulo: Cortez, 2010. Gohn, M. G. Educação nãoformal e o educador social. Atuação no Desenvolvimento de 
[8] Projetos Sociais. São Paulo: Editora Cortez, 2008.

[9] Ibge. Censo Demográfico 2010, Instituto Brasileiro de Geografia e Estatística. Estimativas, Populacionais do Brasil. Grandes Regiões, Unidades da Federação e Municípios. Rio de Janeiro, 2010.

[10] Lück, H. Perspectivas da gestão escolar e implicações quanto à formação de seus gestores.

[11] Em Aberto, Brasília, DF, v. 17, n. 72, p. 11-33, fev./jun. 2009 . Disponível em:<http://www.crmariocovas.sp.gov.br/dir_a.php?t=027> Acesso em: 16 out. 2012.

[12] Lück, H; et. al. A escola participativa: o trabalho do gestor escolar. 9. ed. Petrópolis, RJ: Vozes, 2011.

[13] Padilha, P.R. Município que educa: nova arquitetura da gestão pública municipal. São Paulo: Instituto Paulo Freire, 1998.

[14] Paro, V. A educação, a política e a administração: reflexões sobre a prática do diretor de escola. Educação e Pesquisa, São Paulo, v. 36, n.3, p. $1637-778, \quad 1997$ Disponível em:<http://www.scielo.br/pdf/ep/v36n3/v36n3a08.pdf>. Acesso em: 16 out. 2012.

[15] . Educação como crítica de poder: crítica ao senso comum em educação. 2.ed. São Paulo: Cortez, 2010.

[16] . Implicações do caráter político da educação para a administração da escola pública.

[17] Educação e Pesquisa, São Paulo, v.28, n.2, p. 11-23, jul./dez. $2002 . \quad$ Disponível em:<http://www.scielo.br/pdf/ep/v28n2/a02v28n2.pdf>. Acesso em: 16 out. 2012.

[18] Santos, K. C. B. Conselho Escolar: cenários e desafios de uma escola pública de Natal. Dissertação. 107p., 2005 (Mestrado em Educação) - Universidade Federal do Rio Grande do Norte. Centro de Ciências Sociais Aplicadas. Programa de Pós-Graduação em Educação, 2005.

[19] Semed, Secretaria Municipal de Educação de São Luís, out/2011.

[20] Silva, F.R. IDEB da Rede Municipal de Ensino de Barra Mansa: análise das ações dos gestores. 2012.147 p. Dissertação (Mestrado em Educação) - Universidade Estácio de Sá, Rio de Janeiro, 2012.

[21] Souza, C. Políticas Públicas: uma revisão da literatura. Sociologias, n. 16. Porto Alegre. 2006. Disponível em: <www.sielo.br/scielo.php?pid=s1517-45222006000200003\&script=sci>. Acesso em: 12 abr. 2009.

[22] Sposito, M. P. Espaços públicos e tempos juvenis. São Paulo: Global, 2002. 


\section{Capítulo 6}

\section{A percepção dos gestores da rede municipal de ensino de dois vizinhos - PR sobre a expansão do Ensino Fundamental para nove anos 7}

\section{Rosangela Maria Boeno}

Resumo: Este artigo é um recorte da Dissertação de Mestrado da pesquisadora, intitulada "Mudanças na forma de organização do Ensino Fundamental: Um estudo no município de Dois Vizinhos - PR", defendida em 2011 na Pontifícia Universidade Católica do Paraná - PUCPR. Esse texto apresenta os resultados da pesquisa realizada com os gestores da Rede Municipal de Ensino do Município de Dois Vizinhos (PR), a fim de saber quais as impressões desses profissionais da educação a respeito da expansão do Ensino Fundamental para nove anos. Os objetivos desse texto consistem em fazer uma análise das percepções desses profissionais sobre a expansão do Ensino Fundamental para nove anos e, por meio da análise dos depoimentos dos gestores, identificar se os resultados dessa ampliação do Ensino Fundamental resultaram na melhoria da qualidade do ensino ofertado na Rede Municipal do referido município. A metodologia da pesquisa contemplou estudo bibliográfico, tendo como principais referências os estudos de Ferrari (2008), Gusso et. al. (2010) e Montessori (1965). Também realizou-se estudo documental, envolvendo legislação e documentos oficiais, bem como, pesquisa de campo, a qual consolidou-se por meio de entrevistas semiestruturadas com 05 (cinco) gestores da Rede Municipal, sendo a Secretária de Educação em 2011 e cinco diretores das escolas municipais. Quanto aos resultados da presente pesquisa, estes apontam que na opinião dos profissionais que participaram desta pesquisa, comparando-se com o Ensino Fundamental de oito anos, a expansão do Ensino Fundamental para nove anos trouxe resultados positivos no que se refere à qualidade do ensino ofertado na referida Rede de Ensino.

Palavras-chave: Ampliação do Ensino Fundamental. Aprendizagem. Qualidade.

7 Este trabalho foi publicado como artigo no XIII Congresso Nacional de Educação (Educere), da Pontifícia Universidade Católica do Paraná - PUCPR, em 2017. 


\section{INTRODUÇÃO}

A ampliação do número de anos de escolaridade obrigatória é uma conquista almejada há muito tempo no Brasil. Destaca-se que, se por um lado a ampliação do número de anos de escolaridade por si só não garante a melhoria do processo ensino-aprendizagem, por outro lado, a falta de acesso ao ensino formal é extremamente prejudicial aos educandos.

Diante disso, este artigo se volta para a ampliação da obrigatoriedade do ensino na Rede Municipal de Ensino do município de Dois Vizinhos - PR trazendo os resultados das percepções dos gestores da referida Rede de Ensino sobre a expansão do Ensino Fundamental para nove anos, sendo que, por meio da análise dos depoimentos destes profissionais, buscou-se identificar se o resultado dessa ampliação do Ensino Fundamental resultou na melhoria da qualidade do ensino público nos anos iniciais do Ensino Fundamental no supracitado município. Portanto, é parte de um estudo mais amplo, a Dissertação de Mestrado da pesquisadora, intitulada "Mudanças na forma de organização do Ensino Fundamental: Um estudo no município de Dois Vizinhos - PR", defendida em 2011 na Pontifícia Universidade Católica do Paraná - PUCPR.

\section{METODOLOGIA}

A metodologia da pesquisa envolveu estudo bibliográfico, documental e pesquisa de campo, obtidas por meio de entrevistas semiestruturadas. A pesquisa bibliográfica apoiou-se em livros e artigos científicos sobre o tema. Quanto à investigação documental, buscou-se nas publicações do Ministério da Educação (MEC) e da Secretaria de Estado da Educação do Paraná, bem como, na legislação educacional brasileira, a fundamentação necessária para a compreensão do processo que expandiu o Ensino Fundamental para nove anos. Para identificar como os gestores da Rede Municipal de Ensino de Dois Vizinhos - PR compreendem a expansão do Ensino Fundamental, realizou-se entrevista com 05 (cinco) gestores da citada Rede de Ensino, sendo estes: a Secretária Municipal de Educação de Dois Vizinhos em 2011 e 04 (quatro) diretores das escolas municipais. Estes foram identificados como Gestor 1, Gestor 2, Gestor 3, Gestor 4 e Gestor 5. A pesquisa de campo se apoiou num roteiro composto por cinco questões, as quais serão analisadas e discutidas no tópico seguinte.

\section{A OPINIÃO DOS GESTORES DA REDE MUNICIPAL DE ENSINO DE DOIS VIZINHOS - PR, A RESPEITO DO ENSINO FUNDAMENTAL DE NOVE ANOS}

A ampliação do Ensino Fundamental é uma nova forma de organização do ensino, com vistas ao acesso das crianças das camadas populares ao ensino obrigatório, uma vez que em 2006 quando se aprovou a Lei no 11.274/2006, a Pré-Escola ainda não era obrigatória e muitas crianças das camadas populares que deveriam frequentar a última etapa da Educação Infantil não conseguiam acesso a ela, por falta de vaga. Realidade esta que não se verificava nas camadas mais favorecidas economicamente, uma vez que as crianças dessas classes sociais, já estavam inseridas nas escolas particulares. A obrigatoriedade da PréEscola se consolidou somente três anos depois, com a aprovação da Emenda Constitucional no 59/2009.

Diante disso, esta pesquisa, como já mencionado anteriormente, buscou investigar junto aos gestores da Rede Municipal de Ensino de Dois Vizinhos - PR, se a inserção dessas crianças que antes pertenciam à Educação Infantil e que, a partir de 2006 passaram a integrar o Ensino Fundamental vem contribuindo na melhoria da qualidade do ensino na supracitada Rede de Ensino, uma vez que, os alunos que iniciaram o Ensino Fundamental de nove anos em 2007, já estavam concluindo a primeira etapa do Ensino Fundamental em 2011.

Quanto à pesquisa de campo, a questão 01 versou sobre a data de implantação do Ensino Fundamental de nove anos no município de Dois Vizinhos e todos os entrevistados demonstraram conhecimento da data de implantação que ocorreu em 2007.

Sobre a questão 02 que questionou os gestores a respeito da maneira que a Rede Municipal de Ensino se organizou fisicamente para atender a nova forma de organização do Ensino, percebe-se convergência nas falas dos gestores, sendo que por meio dos depoimentos constatou-se que o Município fez adaptações do espaço e dos equipamentos pedagógicos, ou seja, foram realizadas adequações emergenciais, procurando num primeiro momento atender aos alunos do primeiro ano do novo Ensino Fundamental, sem deixar de lado a preocupação com os alunos do Ensino Fundamental de oito anos que iniciavam um processo gradativo de cessação, bem como com os alunos da Educação Infantil que a partir de então seriam atendidos somente nos centros de Educação Infantil e nas escolas rurais. 
Assim sendo, num primeiro ano, não faltaram salas de aula nas escolas municipais, pois foram reaproveitadas as da Pré-Escola e construídas algumas. Percebe-se ainda uma preocupação quanto ao mobiliário da Pré-Escola e do primeiro ano. Todavia, devido à emergência do atendimento aos sujeitos do primeiro ano, constatou-se pela fala de uma gestora que, na ânsia de se atender da melhor maneira possível os alunos da Pré-Escola, foram transferidas mesas e cadeiras propícias à faixa etária da PréEscola e primeiro ano para os centros de educação infantil, acarretando inadequação na turma de primeiro ano, onde os alunos dessa escola receberam as mesas e carteiras maiores. Assim, fica evidente que nem sempre as determinações implementadas nas leis se efetivam com qualidade, às vezes por falta de recursos, outras por falta de tempo para as adaptações necessárias, ou ainda, por outros fatores que interferem no desenvolvimento das políticas públicas.

O MEC adverte para que se tenha muito cuidado em relação a esse processo de transição de uma forma de organização para a outra, pois ambas necessitam de um olhar especial: o Ensino Fundamental de oito anos que passará por processo gradativo de cessação, bem como, o novo Ensino Fundamental que inicia seu processo de implantação. Esse órgão sinaliza para o cuidado em relação ao processo ensinoaprendizagem, mas considerando-se que a parte de estrutura física interfere no processo ensinoaprendizagem, avalia-se como imprescindível que o ambiente físico esteja adaptado à faixa etária dos alunos.

Durante o período de transição entre as duas estruturas, os sistemas devem administrar uma proposta curricular, que assegure as aprendizagens necessárias ao prosseguimento, com sucesso, nos estudos tanto às crianças de seis anos, quanto às de sete anos de idades que estão ingressando em 2006, bem como às crianças ingressantes no, até então,, ensino fundamental de oito anos (BRASIL: MEC/SEB, 2007, p. 09).

Sobre a importância da adequação dos mobiliários à faixa etária infantil, Montessori (1965, p. 42-43), descreve qual seria a sala de aula perfeita para as crianças.

Mandei construir mesinhas de formas variadas, que não balançassem, e tão leves que duas crianças de quatro anos pudessem fàcilmente (SIC!) transportálas; cadeirinhas, de palha ou de madeira, igualmente bem leves e bonitas, e que fôssem (SIC!) uma reprodução, em miniatura, das cadeiras de adultos, mas proporcionadas às crianças. Encomendei poltroninhas de madeira com braços largos e poltroninhas de vime, mesinhas quadradas para uma só pessoa, e mesas com outros formatos e dimensões, recobertas com toalhas brancas, sôbre (SIC!) as quais seriam colocados vasos de folhagens ou de flôres (SIC!).

A autora complementa:

O posicionamento de Montessori expressa a importância de um ambiente que atenda às necessidades da criança pequena, onde ela possa circular livremente, onde ela mesma possa pegar os objetos que deseja, um ambiente acessível e ao mesmo tempo agradável. Uma sala de aula nos moldes propostos pela autora reflete um ambiente lúdico, prazeroso que possibilita o desenvolvimento da imaginação, da criatividade, da autonomia e da aprendizagem de maneira lúdica, o que vem ao encontro da proposta do MEC para o Ensino Fundamental de nove anos, principalmente para o primeiro ano e se evidencia na fala dos autores/organizadores do documento "Ensino Fundamental de nove anos: orientações para a inclusão da criança de seis anos de idade":

[...] os espaços educativos, os materiais didáticos, o mobiliário e os equipamentos precisam ser repensados para atender às crianças com essa nova faixa etária no ensino fundamental, bem como à infância que já estava nessa etapa de ensino com oito anos de duração (BRASIL: MEC/SEB, 2007, p. 08).

Quanto à questão 03 que buscou saber como a Rede Municipal de Ensino se organizou pedagogicamente para atender essa nova forma de organização do ensino, ficou evidente que a base da organização pedagógica se deu por meio da formação, seja esta continuada, cursos de extensão ou mesmo por meio de leituras. Houve ainda reelaboração dos planejamentos procurando atender a nova proposta de ensino. Além disso, foi mencionado por alguns gestores o investimento em materiais pedagógicos, tais como jogos e parquinhos infantis.

Destacou-se na fala do Gestor 1, a preocupação em oferecer por meio da escola o acesso à brincadeira, ao lúdico, tendo em vista que para as crianças oriundas do espaço rural, o acesso aos parques infantis é mais 
limitado. Isso denota a preocupação da gestora em relação à oferta de oportunidades semelhantes aos alunos que residem no espaço rural em relação aos que vivem na sede do município.

Em se tratando da formação de professores e da reorganização curricular por meio do planejamento, Brasil: MEC/SEB (2007, p. 08) defende

A ampliação do ensino fundamental demanda, ainda, providências para o atendimento das necessidades de recursos humanos - professores, gestores e demais profissionais de educação - para lhes assegurar, entre outras condições, uma política de formação continuada em serviço, o direito ao tempo para o planejamento da prática pedagógica, assim como melhorias em suas carreiras (grifo nosso).

No que diz respeito ao papel da brincadeira no contexto escolar, Gusso et al. (2010, p. 16) assegura que "[...] a didática pode se apropriar dos elementos do brincar para tornar o aprendizado mais instigante e desafiador". Borba (2007, p. 39) complementa:

[...] o brincar é um espaço de apropriação e constituição pelas crianças de conhecimentos e habilidades no âmbito da linguagem, da cognição, dos valores e da sociabilidade. E que esses conhecimentos se tecem nas narrativas do dia-adia, constituindo os sujeitos e a base para muitas aprendizagens e situações em que são necessários o distanciamento da realidade cotidiana, o pensar sobre o mundo e o interpretá-lo de novas formas, bem como o desenvolvimento conjunto de ações coordenadas em torno de um fio condutor comum.

Percebeu-se que a brincadeira é um importante recurso do processo ensino-aprendizagem, pois por meio do brincar são estimulados diversos aspectos do desenvolvimento humano: a criatividade, a imaginação, a socialização, os vínculos afetivos, o estabelecimento de regras e o cognitivo, principal objetivo do trabalho escolar.

Outra etapa do ensino que merece destaque é a Educação Infantil, pois com as mudanças no Ensino Fundamental, antecipando a matrícula dos alunos nesta etapa, ocorreram alterações na organização da Educação Infantil, principalmente na Pré-Escola, sendo que a questão 04 buscou saber dos gestores se essa mudança na forma de organização do Ensino Fundamental ocasionou alterações também na organização da Educação Infantil.

Nos depoimentos dos gestores, evidenciou-se que houve a transferência do atendimento da Pré-Escola das Escolas Municipais para os Centros de Educação Infantil, pois até a implantação do Ensino Fundamental de nove anos, a última etapa da Educação Infantil, o jardim III, era ofertado nas escolas. Observou-se ainda que nas Escolas Rurais, pela distância da sede, permaneceu a oferta da última etapa da Pré-Escola nas escolas, porém o atendimento passou a ser para o Jardim II, tendo em vista que, a faixa etária correspondente ao Jardim III passou então a integrar o Ensino Fundamental de nove anos.

É visível nas falas dos gestores que num primeiro momento, os esforços do Município se centraram na busca de alternativas de acesso dos alunos a esta primeira etapa da Educação Básica - a Educação Infantil. Para isso foram construídas salas de aula, adquiridos e construídos novos Centros de Educação Infantil (o que se expressa no depoimento do gestor 1 , na questão 02 ). Pela sua relevância, a seguir transcreve-se o depoimento desse gestor.

Gestor 1: Foram feitas algumas mudanças na estrutura física, sendo adquirido um Centro de Educação Infantil, construídos dois novos Centros, sendo que um deles com atendimento específico para a Pré-Escola. As turmas de Pré-Escola que funcionavam nas escolas municipais, foram remanejadas para os centros, abrindo espaço para os $1^{\circ}$ anos do Ensino Fundamental de nove anos. Também foram construídas algumas salas de aula, ampliando as escolas e investindo em equipamentos, tais como mesinhas e cadeirinhas.

Outro ponto que se destacou nas falas do gestor 1 e do gestor 2 refere-se ao atendimento em meio período para as turmas de Pré-Escola, procurando ampliar o acesso à Educação Infantil. Apesar das respostas de modo geral, direcionarem-se mais à estrutura física e organizacional, nas falas de dois gestores, emergiu a preocupação com o pedagógico.

A gestora 2 em sua fala demonstrou que as mudanças que ocorreram nos aspectos físicos são importantes, mas que o pedagógico merece destaque e por meio de seu depoimento ela assegura que foi feito um investimento em recursos humanos, ou seja, as coordenações pedagógicas que passaram a compor as 
equipes pedagógico-administrativas dos Centros de Educação Infantil são importantes contribuições ao processo de ensino-aprendizagem nesta primeira etapa da Educação Básica.

Sobre a relevância de um trabalho articulado que ultrapasse a mera formalização legal, Gusso et al. (2010, p. 12) se pronuncia:

A compreensão da infância como historicamente situada implica que a escola, em seu conjunto, efetive um trabalho articulado e com unidades de propósitos educativos. Esses propósitos orientarão o trabalho desenvolvido pelos professores, portanto devem ser discutidos e compreendidos pelo conjunto dos profissionais da unidade escolar, além de devidamente sistematizados na proposta pedagógica.

Fazendo uma interligação entre a fala da gestora 2 e da autora acima citada, verifica-se que todo o trabalho escolar deve estar em sintonia, o pedagógico, com o administrativo, a coordenação pedagógica com a direção e o grupo de professores, buscando sempre o objetivo principal que é o desenvolvimento integral do educando. Outro aspecto que a referida autora remete e considerando os depoimentos já analisados, é a questão do planejamento, pois os gestores, na questão 03, comentaram que foram reelaborados os planejamentos do Ensino Fundamental.

Já na questão 05, buscou-se saber dos gestores, quais as modificações implementadas na escola para atender à nova organização do Ensino Fundamental. Os depoimentos acima dos gestores enfatizaram a organização do ambiente físico, seja o reaproveitamento das salas da Pré-Escola ou mesmo algumas construções.

Na fala da gestora 1, ela afirma que foram investidos em mesas e cadeiras para a faixa etária em questão, no caso as salas dos primeiros anos. No entanto, a fala da gestora 4 divergiu da afirmação da gestora 1. Assim sendo, acredita-se que para algumas escolas foram adquiridos os mobiliários e para outras não, pois a gestora 1, deixou claro que as adaptações foram feitas onde foi possível. Outro ponto que mereceu destaque na fala da gestora 4, é que na escola que ela estava na direção houve solicitação das próprias professoras para que as carteiras fossem maiores e individuais.

Diante do exposto, é importante destacar que todas as mudanças que ocorreram foram emergenciais e, além disso, um fator que interferiu significativamente na estrutura física das escolas foi a falta de escolas municipais e estaduais no Município, de modo que algumas escolas funcionavam compartilhadamente, ou seja, Estado e Município utilizavam o mesmo prédio. Dessa maneira, algumas escolas que não possuíam um espaço que atendesse à demanda precisavam utilizar o mesmo mobiliário para a Educação Infantil e para os alunos das séries/anos finais do Ensino Fundamental ou mesmo para os do Ensino Médio. Esse pode ter sido o fator decisivo para que algumas escolas permanecessem com carteiras maiores nas salas de primeiro ano.

Também aparece no relato de alguns gestores a preocupação com o pedagógico, o investimento neste setor, bem como a reorganização curricular e a orientação aos pais sobre esta nova forma de organização do ensino e a formação dos professores. Considera-se primordial a informação às famílias, para que tanto professores quanto às famílias consigam compreender esse processo e trabalhar em sintonia, pois embora o conhecimento sistematizado seja responsabilidade da escola, o processo educativo vai além da esfera escolar, envolvendo principalmente a família.

Gusso et al. (2010, p. 16-17) ressalta a importância do vínculo estabelecido nos primeiros dias de aula entre escola e família.

Uma boa socialização das crianças depende da relação escola-família e da recepção realizada por parte dos profissionais da instituição. Portanto, para que se compreenda e efetive os cuidados necessários ao receber crianças pequenas é fundamental que aconteçam momentos de formação para todos os profissionais que compõem o espaço escolar, durante os quais serão delineadas estratégias para lidar com o período de ingresso destas crianças na escola, na particularidade de cada grupo, em virtude de situações, tais como a separação de seu grupo familiar e do acesso a um espaço diferente daqueles que frequentavam habitualmente. 
A respeito da formação do educador, o próprio MEC afirma que é uma tarefa necessária, porém representa um grande desafio para os sistemas de ensino, pois a formação precisa ser sólida e significativa, que venha ao encontro das necessidades dos sujeitos envolvidos nesse processo.

Assegurar essa formação tem sido o desafio de todos os sistemas. Uma formação sensível aos aspectos da vida diária do profissional, especialmente no tocante às capacidades, atitudes, valores, princípios e concepções que norteiam a prática pedagógica. Promover a formação continuada e coletiva é uma atitude gerencial indispensável para o desenvolvimento de um trabalho pedagógico qualitativo que efetivamente promova a aprendizagem dos alunos (BRASIL: MEC, 2004, p. 26).

E, sobre a organização do trabalho pedagógico versou a questão 6 que investigou a concepção dos gestores a respeito de como deveria se estruturar o trabalho realizado com as crianças do primeiro ano e, de acordo com o ponto de vista dos gestores entrevistados, a essência do trabalho no primeiro ano deveria ser a integração entre alfabetização e psicomotricidade. A questão da ludicidade permeando o trabalho docente também foi levantada como importante neste ano inicial do Ensino Fundamental.

Outro fator apontado por dois gestores foi o respeito à faixa etária em que a criança se encontrava, o que remete à formação do professor, pois o respeito às particularidades da criança, à sua faixa etária ou ao seu ritmo está intimamente ligado às concepções de infância que o professor possui e consequentemente ao seu nível de conhecimento teórico obtido através de leituras e de cursos, ou seja, por meio de sua formação.

Sem repensar a formação do educador para essa criança de seis anos e que materiais e metodologias utilizar para tal, poderemos errar na dose e acabar dando demais, o que sufocará a criança porque a quantidade não é e não pode ser a prioridade; ou dando de menos, porque podemos ainda estar acreditando que, por se tratar de uma criança ainda tão tenra, conteúdos devem ser poucos, e as outras atividades tomarem o lugar mais amplo. É o desafio e, como todos nós sabemos que assim o é, cabe-nos, diante da constatação, garantir o brincar, a socialização, o desenvolvimento motor e os processos mais formais de letramentos em que constem, claramente, alfabetização, raciocínio lógicomatemático e gêneros textuais (ALMEIDA, 2008, p. 23).

0 gestor 2 fez referência ainda à importância da afetividade nesta primeira etapa do Ensino Fundamental. Este salientou também a necessidade de se considerar os conhecimentos prévios que a criança possui. Por meio do seu depoimento fica claro que ele considera a criança um ser integral.

Falar que a escola deve proporcionar formação integral (intelectual, afetiva e social) às crianças é comum hoje em dia. No início do século passado, porém, essa ideia foi uma verdadeira revolução no ensino. Uma revolução comandada por um médico, psicólogo e filósofo francês chamado Henri Wallon (18791962). Sua teoria pedagógica, que diz que o desenvolvimento intelectual envolve muito mais do que um simples cérebro, abalou as convicções numa época em que memória e erudição eram o máximo em termos de construção do conhecimento (FERRARI, 2008, s/p).

Ferrari (2008, s/p) complementa:

Wallon foi o primeiro a levar não só o corpo da criança, mas também suas emoções para dentro da sala de aula. Fundamentou suas ideias em quatro elementos básicos que se comunicam o tempo todo: a afetividade, o movimento, a inteligência e a formação do eu como pessoa.

A afetividade é uma necessidade básica do ser humano, pois é por meio dela que as pessoas estabelecem vínculos, se relacionam pessoalmente e interpessoalmente. Evidencia-se então que o desenvolvimento dos vínculos afetivos durante a infância auxilia significativamente no desenvolvimento da pessoa e a aprendizagem está intimamente relacionada à questão afetiva. Daí a importância do professor nesse contexto, cabendo a ele a tarefa principal de estabelecer vínculo com a turma e também de mediar esse processo entre os próprios educandos.

Em relação aos conhecimentos prévios que a criança possui, estes, segundo Gasparin (2003), devem representar o ponto de partida para o desenvolvimento de todo o trabalho escolar. Além disso, esses 
conhecimentos fornecem importantes contribuições ao educador, pois por meio deles, o professor percebe o grau de instrução da criança e suas famílias, questões emocionais que as crianças expressam em suas falas, enfim, é uma forma de começar um contato com a criança, no sentido de conhecer quem é essa criança, quais são suas necessidades, seus anseios, seus medos, suas frustrações. A partir desse contato inicial e diário, é que vão se estabelecendo os vínculos afetivos fundamentais ao processo de aprendizagem dessas crianças.

O interesse do professor por aquilo que os alunos já conhecem, é uma ocupação prévia sobre o tema que será desenvolvido. É um cuidado preliminar que visa saber quais as 'pré-ocupações' que estão nas mentes e nos sentimentos dos escolares. Isso possibilita ao professor desenvolver um trabalho pedagógico mais adequado, a fim de que os educandos, nas fases posteriores do processo, apropriem-se de um conhecimento significativo para suas vidas (GASPARIN, 2003, p. 16).

Esse conhecimento da realidade da turma, do que os alunos já sabem sobre o assunto, permite que o planejamento do professor se volte aos anseios dos educandos, ou seja, a instrumentalização que o professor fará durante suas aulas, precisa acrescentar conhecimento ao que os alunos já sabem, para que surja um novo conhecimento, objetivo principal da educação escolar.

Tanto o gestor 4, quanto o 5, ressaltaram que o objetivo principal do trabalho nesse primeiro ano, não é a alfabetização, isto ficou explícito no depoimento do gestor 4 e implícito na fala do gestor 5, quando este apontou para o cuidado em relação ao novo primeiro ano, o qual não deve ser confundido com a antiga primeira série. Isso denota que os gestores têm clareza de que o primeiro ano do Ensino Fundamental de nove anos e, provavelmente os seguintes, devem atender a uma nova estrutura curricular que se volte às necessidades dos alunos pertencentes ao Ensino Fundamental de nove anos. E, suas declarações vêm ao encontro das determinações do Ministério da Educação.

[...] não se trata de transferir para as crianças de seis anos os conteúdos e atividades da tradicional primeira série, mas de conceber uma nova estrutura de organização dos conteúdos em um Ensino Fundamental de nove anos, considerando o perfil de seus alunos (BRASIL: MEC, 2004, p. 17).

O Ensino Fundamental de nove anos é uma nova forma de organização do ensino com especificidades próprias e, portanto o trabalho com este primeiro ano, não deve se restringir aos conteúdos da primeira série do Ensino Fundamental de oito anos nem à repetição dos conteúdos da última etapa da Educação Infantil. É um período de transição, mas o mais importante a considerar é que as crianças dessa primeira etapa do ensino obrigatório sejam atendidas de acordo com as suas necessidades reais, que tenham acesso ao processo de alfabetização e letramento, às diversas disciplinas do ensino formal, ao desenvolvimento das diversas expressões: a música, a brincadeira, às artes, etc., que elas possam ser crianças, que possam ser elas mesmas.

A questão 07 interrogou os profissionais a respeito do corte etário para o ingresso no primeiro ano do Ensino Fundamental de nove anos, buscando saber a opinião dos gestores em relação ao ingresso das crianças no Ensino Fundamental com seis anos completos ou a completar até 31 de março do ano em curso, bem como, em relação às que completam seis anos de idade no decorrer do ano letivo.

A posição dos gestores, de modo geral, foi de respeito ao corte etário de seis anos no início do ano letivo, conforme determinação do MEC. Mesmo o gestor 1, quando disse "Se for trabalhado de maneira lúdica [...] poderá contribuir para um amadurecimento que acontecerá aos seis anos" deixou implícito que acredita que aos seis anos a criança tem mais maturidade para o ingresso no ensino obrigatório.

O gestor 4 no início de seu depoimento sinalizou para a questão da maturidade, mas na sequência explicou que essa questão tem mais a ver com as oportunidades de acesso à cultura escolar do que a idade propriamente dita, afirmando ao final de sua fala que a questão da idade é relativa. Desse modo, parece que, apesar das justificativas acima apresentadas, os gestores consideraram que devido à heterogeneidade de níveis com que as crianças ingressam no ensino formal, ainda a melhor alternativa seria o respeito ao corte etário. 
O MEC explicita seu posicionamento a respeito do ingresso da criança aos seis anos de idade:

A idade cronológica não é, essencialmente, o aspecto definidor da maneira de ser da criança e de sua entrada no Ensino Fundamental. Com base em pesquisas e experiências práticas, construiu-se uma representação envolvendo algumas das características das crianças de seis anos que as distinguem das de outras faixas etárias, sobretudo pela imaginação, a curiosidade, o movimento e o desejo de aprender aliados à sua forma privilegiada de conhecer o mundo por meio do brincar. Nessa faixa etária a criança já possui grande capacidade de simbolizar e compreender o mundo, estruturando seu pensamento e fazendo uso de múltiplas linguagens. Esse desenvolvimento possibilita a elas participar de jogos que envolvem regras e se apropriar de conhecimentos, valores e práticas sociais construídos na cultura. Nessa fase, vivem um momento crucial de suas vidas no que se refere à construção de sua autonomia e de sua identidade (BRASIL: MEC, 2004, p. 19).

E em relação à linguagem escrita, o MEC assegura:

Especificamente em relação à linguagem escrita, a criança, nessa idade ou fase de desenvolvimento, que vive numa sociedade letrada, possui um forte desejo de aprender, somado ao forte desejo que tem para ela frequentar uma escola. 0 desenvolvimento maior ou menor desses aspectos e as possibilidades de aprendizagem dessas crianças são determinados pelas experiências e pelas qualidades das interações às quais se encontram expostas no meio sociocultural em que vivem ou frequentam. Daí o papel decisivo da família, da escola e dos professores, como mediadores culturais no processo de formação humana das crianças (BRASIL: MEC, 2004, p. 19-20).

A posição do MEC é de que não é a idade cronológica a definidora da entrada da criança no Ensino Obrigatório, mas que algumas características das crianças de seis anos levam a reflexão de que as crianças dessa faixa etária já têm uma capacidade maior para estarem ingressando no ensino formal. Mas, o posicionamento do MEC, principalmente no que se refere às questões da linguagem escrita é de que o desenvolvimento desses aspectos tem relação direta com as oportunidades de contato, ou seja, as experiências que a criança já possui, seja na família ou na escola, neste caso, na Educação Infantil.

Dessa maneira, compreende-se que a idade cronológica pode auxiliar na questão da maturação da criança, mas que o meio social e as experiências às quais a criança foi submetida são determinantes para o seu desenvolvimento, o que vem ao encontro da fala do gestor 4, quando este afirmou que a questão da maturidade está mais relacionada às experiências que a criança é submetida do que à idade propriamente dita.

Conforme Ferrari (2008, s/p):

Todo aprendizado é necessariamente mediado [...]. Segundo Vygotsky [...] o primeiro contato da criança com novas atividades, habilidades ou informações deve ter a participação de um adulto. Ao internalizar um procedimento, a criança 'se apropria' dele, tornando-o voluntário e independente. Desse modo, o aprendizado não se subordina totalmente ao desenvolvimento das estruturas intelectuais da criança, mas um se alimenta do outro, provocando saltos de nível de conhecimento. 0 ensino, para Vygotsky, deve se antecipar ao que o aluno ainda não sabe nem é capaz de aprender sozinho, porque, na relação entre aprendizado e desenvolvimento, o primeiro vem antes. É a isso que se refere um de seus principais conceitos, o de zona de desenvolvimento proximal, que seria a distância entre o desenvolvimento real de uma criança e aquilo que ela tem o potencial de aprender - potencial que é demonstrado pela capacidade de desenvolver uma competência com a ajuda de um adulto. Em outras palavras, a zona de desenvolvimento proximal é o caminho entre o que a criança consegue fazer sozinha e o que ela está perto de conseguir fazer sozinha. Saber identificar essas duas capacidades e trabalhar o percurso de cada aluno entre ambas são as duas principais habilidades que um professor precisa ter, segundo Vygotsky. 
Em vista disso, o processo de aprendizagem da linguagem escrita tem relação direta com necessidades históricas e sociais e, portanto dependem do contexto histórico no qual a criança está vivendo. Dependendo da época, do local e da cultura, as necessidades serão diferentes.

Todo o processo de implantação dessa nova forma de organização do ensino traz engendrado em sua proposta o processo de avaliação e consequentemente, as concepções sobre a estruturação do ensino: em séries, ciclos, de forma mista, etc., assunto abordado no próximo questionamento.

A questão 08 interrogou os gestores sobre a maneira como o Município vem se estruturando historicamente em relação à organização do Ensino Fundamental em ciclos, séries ou de forma mista, a fim de saber qual a percepção desses profissionais em relação a essas formas de organização do ensino.

Observou-se que os gestores, de modo geral, conhecem como se processou historicamente na Rede Municipal de Ensino, a organização do ensino fundamental: inicialmente se organizou em série, depois ciclo básico (4 anos), posteriormente, dois ciclos de dois anos cada e naquele momento um ciclo de alfabetização de dois anos e os três últimos anos ( $3^{\circ}$, $4^{\circ}$ e e $5^{\circ}$ ) em seriação, ou seja, de forma mista.

É importante destacar que o gestor 2, não mencionou como se estruturou historicamente esse processo, detendo-se apenas à maneira que o município procedeu no momento de implantação do Ensino Fundamental de nove anos. Então, percebeu-se no depoimento do gestor 2, a defesa da forma de organização por ciclo, principalmente nos três anos iniciais. Já os demais gestores manifestaram que a melhor forma de organização vivenciada no município é a mista, com o ciclo de alfabetização de dois anos e os três últimos anos dos anos iniciais do Ensino Fundamental, com seriação.

Diante do exposto, verificou-se que quem já vivenciou as demais formas de organização do ensino, prefere a forma mista, a atual (um ciclo de alfabetização de dois anos e os três anos finais de forma seriada).

Constatou-se nas falas dos gestores que o objetivo não é a reprovação, mas o domínio dos conteúdos. Isso se expressou claramente nos depoimentos, uma vez que o termo "reprovação" foi pouco utilizado, e quando dele se fez uso, a justificativa seguinte demonstrou que a preocupação central era o aprendizado, ou seja, os gestores utilizaram os termos "retomar o processo", "segurar o aluno que não tem as mínimas condições de acompanhar a série seguinte", "os alunos que não se apropriaram dos conteúdos básicos do ano, podem ficar retidos".

Quanto ao MEC, este órgão apresenta sua posição referente à forma de estruturação do ensino, o que se expressa no Art. 23 da LDB no 9.394/96:

A educação básica poderá organizar-se em séries anuais, períodos semestrais, ciclos, alternância regular de períodos de estudos, grupos não-seriados, com base na idade, na competência e em outros critérios, ou por forma diversa de organização, sempre que o interesse do processo de aprendizagem assim o recomendar (BRASIL, 1996).

Ainda a Lei 11.274/2006 enaltece a flexibilidade da organização da Educação Básica, retomando o que se estabelece no artigo 23 da LDB em vigor. Apesar do MEC ressaltar a flexibilização estabelecida na LDB, percebe-se um olhar especial para as crianças do primeiro ano do Ensino Fundamental de nove anos, o que se evidencia no documento "Ensino Fundamental de nove anos - Orientações Gerais":

Recomenda-se que as escolas organizadas pela estrutura seriada não transformem esse novo ano em mais uma série, com as características e a natureza da primeira série. Assim, o Ministério da Educação orienta que, nos seus projetos político-pedagógicos sejam previstas estratégias possibilitadoras de maior flexibilização de seus tempos, com menos cortes e descontinuidades. Estratégias que, de fato, contribuam para o desenvolvimento da criança, possibilitando-lhe, efetivamente, uma ampliação qualitativa do seu tempo na escola (BRASIL: MEC, 2004, p. 22-23).

Nos últimos tempos, há uma acirrada discussão a respeito da organização do Ensino em ciclo. Em vista disso, a Resolução CNE/CEB no 07/2010 de 14 de dezembro de 2010 recomenda que os três primeiros anos do Ensino Fundamental sejam organizados em um único ciclo pedagógico, inclusive para as escolas que praticam o sistema seriado.

Assim sendo, como o objetivo não é a reprovação e sim a aprendizagem dos educandos, considera-se primordial que a passagem do primeiro ao segundo ano de escolaridade se dê de forma contínua, sem interrupções. 0 ideal seria que a criança não precisasse repetir o ano em nenhuma série/ano, mas 
considerando-se que nem sempre os recursos disponíveis atendem às necessidades de recursos humanos que as escolas necessitam, pessoal de apoio suficiente: aulas de contraturno, reforço paralelo, professores auxiliares principalmente no ciclo de alfabetização, a seriação, a partir do terceiro ano de escolaridade ainda representa uma alternativa aos municípios, possibilitando às crianças que não conseguiram se apropriar dos conteúdos básicos do ano, reverem o processo e conseguirem consolidar determinados saberes que não foram consolidados em dois anos de alfabetização.

E a questão da aprendizagem, principal objetivo do processo de ensino, leva ao questionamento de como os gestores vinham percebendo essa trajetória da nova organização do Ensino Fundamental, buscando identificar se na opinião dos gestores a antecipação do ingresso no Ensino Fundamental vinha contribuindo para a melhoria do processo ensino-aprendizagem. Percebeu-se que apenas um dos gestores afirmou que parcialmente a nova organização do ensino resultou em melhoria da aprendizagem, mas ele justificou que é possível a melhoria desde que os profissionais façam um trabalho condizente com a faixa etária de desenvolvimento das crianças, respeitando seu nível de maturidade. Os demais defendem que essa antecipação contribuiu na melhoria da aprendizagem dos alunos.

O PNE estabelece [...] que a implantação progressiva do Ensino Fundamental de nove anos, com a inclusão das crianças de seis anos, deve se dar em consonância com a universalização do atendimento na faixa etária de 7 a 14 anos. Ressalta também que esta ação requer planejamento e diretrizes norteadoras para o atendimento integral da criança em seu aspecto físico, psicológico, intelectual e social, além de metas para a expansão do atendimento, com garantia de qualidade. Essa qualidade implica assegurar um processo educativo respeitoso e construído com base nas múltiplas dimensões e na especificidade do tempo da infância, do qual também fazem parte as crianças de sete e oito anos (BRASIL: MEC, 2004, p. 14-15).

Ainda se percebeu na fala de outro gestor que este acreditava que, pelas diferenças de conhecimento que as crianças possuíam ao adentrarem no primeiro ano, dificultava um trabalho mais eficaz nesse ano. Então na visão desse gestor a melhoria do processo só ocorrerá de fato, quando a Educação Infantil for obrigatória.

Sobre a importância da Pré-Escola e do ingresso antecipado das crianças no ensino obrigatório, o MEC assegura:

Outro fator importante para a inclusão das crianças de seis anos na instituição escolar deve-se aos resultados de estudos demonstrarem que, quando as crianças ingressam na instituição escolar antes dos sete anos de idade, apresentam, em sua maioria, resultados superiores em relação àquelas que ingressam somente aos sete anos. A exemplo desses estudos, podemos citar o Sistema Nacional de Avaliação da Educação Básica (Saeb) 2003. Tal sistema demonstra que crianças com histórico de experiência na pré-escola obtiveram maiores médias de proficiência em leitura: vinte pontos a mais nos resultados dos testes de leitura (BRASIL: MEC/SEB, 2007, p. 05-06).

Então, constatou-se nas falas dos gestores, que o ponto de vista da maioria dos entrevistados era de que o Ensino Fundamental de nove anos resultou em melhoria no processo ensino-aprendizagem.

\section{CONSIDERAÇÕES FINAIS}

A partir dos depoimentos dos gestores da Rede Municipal de Ensino de Dois Vizinhos - PR constatou-se que, o município conseguiu se organizar bem no que se refere à estrutura física, mobiliário e recursos pedagógicos para atender os alunos do Ensino Fundamental de nove anos, os do Ensino Fundamental de oito anos (em processo de cessação) e os alunos da Educação Infantil.

Verificou-se que com a nova organização do Ensino Fundamental, na referida Rede de Ensino, houve a transferência dos alunos da Pré-Escola para os Centros de Educação Infantil, o que mobilizou o município a investir na estrutura física dos Centros, ou seja, as mudanças ocorridas no Ensino Fundamental interferiram diretamente na organização da Educação Infantil.

A Rede Municipal se organizava em 2011 de maneira mista, com um ciclo de alfabetização (alunos do 1ํe e do $2^{\circ}$ ano) e seriação (alunos do $3^{\circ}$, $4^{\circ}$ e $5^{\circ}$ ano), evidenciando-se nas falas dos gestores que esta forma de organização do Ensino Fundamental tinha uma boa aceitação dos entrevistados. 
A pesquisa demonstrou que, na percepção dos gestores participantes desse estudo, a expansão do Ensino Fundamental resultou na melhoria da qualidade do ensino ofertado aos alunos da supracitada Rede de Ensino, uma vez que, os alunos do Ensino Fundamental de nove anos vinham apresentando melhor aprendizado em relação aos do Ensino Fundamental de oito anos.

\section{REFERÊNCIAS}

[1] Almeida, G. P. de. Desenvolvimento da escrita: 100 propostas práticas para o trabalho com crianças de seis anos. Rio de Janeiro, RJ: $\quad$ Wak, 2008. Borba, Ângela Meyer. 0 brincar como um modo de ser e estar no mundo. In: BRASIL. Mec/Seb. Ensino Fundamental de 9 anos: orientações para a inclusão da criança de 6 anos de idade. 2. ed. Brasília, 2007.

[2] Brasil. Lei n. 9.394, de 20 de dezembro de 1996. Estabelece as Diretrizes e Bases da Educação Nacional. Brasília. 1996. Disponível em: <http://www.planalto.gov.br/ccivil_03/leis/L9394.htm \. Acesso em: 10 mai. 2016.

[3] _ _ Ministério da Educação. Secretaria de Educação Básica/Departamento de Políticas de Educação Infantil e Ensino Fundamental/ Coordenação Geral do Ensino Fundamental. Ensino Fundamental de nove anos: Orientações Gerais. Brasília: MEC, 2004.

[4] ___. Lei n. 11. 274, de 06 de fevereiro de 2006. Altera a redação dos arts. 29, 30, 32 e 87 da Lei no 0.394 , de 20 de dezembro de 1996, que estabelece as diretrizes e bases da educação nacional, dispondo sobre a duração de 9 (nove) anos para o ensino fundamental, com matrícula obrigatória a partir dos 6 (seis) anos de idade. Brasília. Disponível em: <http://www.planalto.gov.br/ccivil_03/_ato2004-2006/2006/lei/l11274.htm. Acesso em: 09 mai. 2016.

[5] _. Mec/seb. Ensino Fundamental de 9 anos: orientações para a inclusão da criança de 6 anos de idade. 2. ed. Brasília, 2007.

[6] Emenda Constitucional n. 59, de 11 de novembro de 2009. Acrescenta $\S 3$ ao art. 76 do Ato das Disposições Constitucionais Transitórias para reduzir, anualmente, a partir do exercício de 2009, o percentual da Desvinculação das Receitas da União incidente sobre os recursos destinados à manutenção e desenvolvimento do ensino que trata o art. 212 da Constituição Federal, dá nova redação aos incisos I e VII do art. 208, de forma a prever a obrigatoriedade do ensino de quatro a dezessete anos e ampliar a abrangência dos programas suplementares para todas as etapas da educação básica, e dá nova redação ao § 4º do art. 211 e ao § 3o do art. 212 e ao caput do art. 214, com a inserção neste dispositivo de inciso VI. Brasília. 2009. Disponível em: <http://www.planalto.gov.br/ccivil_03/Constituicao/Emendas/Emc/emc59.htm>. Acesso em: 09 mai. 2016.

[7] _ Resolução CNE/CEB n. 7, de 14 de dezembro de 2010. . Fixa Diretrizes Curriculares Nacionais para o Ensino Fundamental de 9 (nove) anos. Brasília. 2010c. Disponível em: <http://portal.mec.gov.br/dmdocuments/rceb007_10.pdf \. Acesso em: 22 mar. 2016.

[8] Ferrari, Márcio. Henri Wallon, o educador integral: Militante apaixonado, o médico, psicólogo e filósofo francês mostrou que as crianças têm também corpo e emoções (e não apenas cabeça) na sala de aula. Nova Escola: Edição Especial - Grandes Pensadores. Julho, 2008. Disponível em: <http://revistaescola.abril.com.br/edicoesespeciais/022.shtml. Acesso em: 21 jan. 2011.

[9] L_ Lev Vygotsky, o teórico do ensino como processo social: A obra do psicólogoressalta o papel da escola no desenvolvimento mental das crianças e é uma dasmais estudadas pela pedagogia contemporânea. Nova Escola: Edição Especial -Grandes Pensadores. Julho, 2008. Disponível em: <http://revistaescola.abril.com.br/edicoesespeciais/022.shtml $\geq$. Acesso em: 21 jan. 2011.

[10] Gasparin, João Luiz. Uma didática para a pedagogia histórico-crítica. 2. ed. Campinas, SP: Autores Associados, 2003.

[11] Gusso, Mari et al; Amaral, Arleandra Cristina Talin do.; Casagrande, Roseli Correia de Barros; Chulek, Viviane (Orgs). Ensino Fundamental de nove anos: orientações pedagógicas para os anos iniciais. Curitiba, PR: Secretaria de Estado da Educação, 2010.

[12] Montessori, Maria. Pedagogia Científica: A Descoberta da Criança. Editora Flamboyant, 1965. 


\section{Capítulo 7}

\section{Gestão democrática da escola: Desenhando possibilidades, repensando sua atuação}

\section{José Otávio da Silva}

Mônica de Fátima Guedes de Oliveira

Nayane Helen Mamede Guedes

Resumo: Este trabalho, surgiu a partir de uma pesquisa de campo, tendo como foco de análise a gestão escolar. A pesquisa, objetivou analisar a gestão das escolas públicas no contexto político do município de Guarabira, Estado da Paraíba, a partir das observações feitas por estudantes do curso de pedagogia durante a realização do estágio supervisionado em gestão educacional. No decorrer do trabalho, apresenta-se significados da democracia participativa, evidenciando os processos da gestão escolar, além de identificar os desafios e encontrar meios para oportunizar a participação da comunidade escolar no contexto da escola pública. Para realizar este estudo, buscou-se como embasamento teórico as ideias de LÜCK (2006), CURY (2005), FREIRE (2001), LIBÂNEO (2001), GADOTTI (2005) e as análises de PARO (2001) e DOURADO (2009) sobre a prática da gestão democrática na escola pública. Trata-se de um estudo de natureza qualitativa, e o recurso metodológico utilizado foi a técnica da observação, realizado por alunos do estágio supervisionado do curso de pedagogia da Universidade Estadual da Paraíba, no município de Guarabira-PB, durante o ano de 2015. 0 referido estudo, está baseado teoricamente em pesquisas que retratam a história da educação no Brasil, que analisam os marcos referenciais da educação no contexto atual e abordam a discussão da política educacional brasileira na atualidade, de forma a entender as relações entre a educação e a sociedade, enfocando a democratização da escola. Os resultados obtidos demonstraram que a democratização da gestão escolar implica a superação dos processos centralizados da gestão educacional, na qual as decisões nascem das discussões coletivas, envolvendo todos os segmentos da escola, orientados pelo sentido político e pedagógico.

Palavras-Chave: Escola, Gestão Democrática, Participação. 


\section{INTRODUÇÃO}

Atualmente é unanimidade a reivindicação por participação e autonomia dentro da nossa sociedade, e mais precisamente nos diversos campos sociais, onde sem nenhuma dúvida, existe uma multiplicidade cultural eminente e forte.

É a partir disto que surge a preocupação com a construção de uma escola democrática, extremamente importante para a conquista de atitudes reflexivas e de possibilidades de mudanças. Portanto, este estudo, parte da problematização de uma realidade vivenciada na escola, sendo que as considerações, as afirmações e as análises presentes no corpo do texto são oriundas das observações realizadas no convívio dos alunos durante o estágio supervisionado em gestão educacional nas escolas públicas municipais do município de Guarabira-PB, durante o ano letivo de 2015, tempo destinado a referida pesquisa.

Além das atividades do estágio, as discussões em sala de aula promovidas pelos diversos componentes curriculares durante o curso de pedagogia e em especial pela área de aprofundamento em gestão educacional, como também as leituras propostas e orientadas no desenrolar da pesquisa, serviram de subsídios para que chegássemos a elaboração deste estudo, objetivando analisar o processo da gestão da escola pública, considerando a realidade observada e vivenciada no espaço pesquisado.

Acreditamos que este trabalho servirá de subsídio para pesquisas futuras sobre a gestão no interior da escola, como também, será um norteador para aqueles que vivenciam no cotidiano a gestão da escola, além de apontar para estudos que refletem as políticas educacionais, com ênfase na gestão da educação pública.

\section{DISCUTINDO A GESTÃO EDUCACIONAL NA ATUALIDADE}

Discutir gestão educacional nos remete a pensar sobre o percurso da educação brasileira nas últimas décadas que, entre outras nuances, demonstram que um longo caminho foi percorrido, marcado por lutas, conquistas e também retrocessos. Foram momentos diversos, ocorridos em vários contextos e cenários políticos formados em cada momento da vida pública brasileira.

\section{CONTEXTUALIZAÇÃO HISTÓRICA DA EDUCAÇÃO BRASILEIRA}

A história da educação brasileira foi marcada e dominada pela presença dos jesuítas, que durante séculos desenvolveram e influenciaram ações que incidiam sobre o processo educativo. Financiados e apoiados pela igreja católica e pelo Estado Português, ofereciam a população um tipo de ensino, que era desenvolvido de acordo com os interesses da ideologia pregada pelo catolicismo no chamado período pósreforma religiosa e por Portugal. A escola brasileira era então, adepta e influenciada pelo catolicismo, cujo objetivo era instruir os filhos dos colonos e catequizar os índios.

Segundo Aranha: 0 fato é que o índio se encontrava à mercê de três interesses, que ora se complementavam, ora se chocavam: a metrópole desejava integrá-lo ao processo colonizador; o jesuíta queria convertê-lo ao cristianismo e aos valores europeus; e o colono queria usá-lo como escravo para o trabalho. (2006, p.141)

0 ensino público financiado pelo Estado e para o Estado, surge no Brasil, após a expulsão dos jesuítas com o propósito de formar cidadãos que atendessem o interesse do governo. Algumas mudanças significativas vão ocorrer com a chegada da família real, especificamente no que tange a uma nova organização educacional, destacando-se a criação de escolas e cursos, dando origem a um modelo imperial, baseado no atendimento as várias áreas e demandas que o campo de trabalho exigia. Com o passar do tempo e em meio a oscilações ocorridas face às mudanças nas esferas políticas e administrativas do Brasil, cujo pensamento iluminista marcava o pensamento social, os portugueses, através do marquês de Pombal institui o "subsídio literário", imposto destinado a financiar reformas projetadas, o que valia também para o Brasil, fazendo com que os professores fossem pagos pelo estado, tornando-os funcionários públicos. Surgindo então, uma nova escola, agora totalmente financiada pelo Estado, uma vez que, os jesuítas em 1759 foram expulsos do Brasil e de todas as possessões portuguesas pelo mundo por determinação do rei de Portugal da época D. José I, influenciado pelo Marquês de Pombal. Nesta época, as escolas eram insuficientes e os professores sem qualificação tinham baixos salários, o que gerava má formação dos alunos.

A partir do século XIX a educação pública brasileira foi influenciada pela cultura copiada dos Estados Unidos, organizada e influenciada pelo pensamento positivista que procurava difundir suas ideias por 
meio da educação. A organização escolar brasileira se deu com avanços e recuos, mas a partir das décadas de 30 e 40, no governo de Getúlio Vargas, passando por grandes transformações. Na década de 30, tivemos a criação do Ministério da Educação, nesse período o governo brasileiro intensificou mudanças na relação entre o Estado e a sociedade, acelerando-se o processo de urbanização e industrialização, sob a égide da lógica do capitalismo liberal. Quanto a educação, passou a predominar nesse período uma pedagogia liberal.

Segundo LIBÂNEO (1985) o termo liberal não seria aquele relacionado ao sentido de "avançado", "aberto", como costuma ser usado. A doutrina liberal apareceu como justificação do sistema capitalista que ao defender a predominância da liberdade e dos interesses individuais na sociedade, estabeleceu uma forma de organização baseada na propriedade privada dos meios de produção, também denominada sociedade de classes. A pedagogia Liberal, portanto, é uma manifestação própria desse tipo de sociedade. Segundo DOURADO (2009), o pensamento pedagógico liberal definia que a função da escola era de preparar os indivíduos para o desempenho de papéis sociais previamente definidos, numa sociedade dada e não questionada, a partir das características individuais. Surgiu nesse período, o movimento pela escola nova, como oposição a essa lógica liberal que era imposta a educação brasileira como verdade absoluta e ideologia de ensino e aprendizagem. É sob a égide de críticas à tendência tradicional/liberal, que surge a proposta da escola nova, esta estabelece um método que prioriza o aluno como o centro de aprendizagem, o professor é o auxiliar da aprendizagem (que de acordo com esta concepção ocorre a partir dos interesses dos docentes). Era a partir dos interesses e motivações intrínsecas que procurava-se organizar as atividades escolares. Logo os conteúdos passariam a obedecer a estruturação psicológica do pensamento da criança, destacando-se o manifesto dos pioneiros da educação (1932), onde continha propostas defendidas por educadores que propagavam uma educação baseada na investigação livre, uma autoeducação, uma aprendizagem desencadeada a partir de um processo ativo. Sobre essa questão, Lourenço Filho, um dos fundadores do movimento da escola nova, destaca: [...] aprende-se observando, pesquisando, perguntando, trabalhando, construindo, pensando e resolvendo situações problemáticas apresentadas, quer em relação a um ambiente de coisas, de objetos e ações práticas, quer em situações de sentido social e moral, reais ou simbólicos. (LOURENÇO FILHO, 1978, p.151). Prosseguindo seu percurso histórico, a educação brasileira segue no governo de Juscelino Kubitschek de forma estagnada, aumentando o índice de analfabetismo no país. A resposta que se engendrou nos meios educacionais veio efetivamente na década de 70, com a concepção tecnicista, esta trataria uma "saída" tanto para a baixa qualidade do ensino, quanto para a falta de acesso e permanência das classes populares na escola. Esta tendência estava assentada na neutralidade científica, tentando corrigir e reordenar os meios de ensinar. Buscou-se uma educação dotada de organização racional, capaz de minimizar as interferências subjetivas. Um fator importantíssimo a ser destacado é que o Brasil no período de implantação da tendência tecnicista estava transitando para um modelo urbano industrial. Logo a educação era impelida a formar sujeitos aptos para suprir a mão-de-obra requisitada para as indústrias, conforme nos assinala SAVIANI (1980). Acrescenta-se que formação técnica deixou uma lacuna na formação das camadas populares, visto que estas eram instruídas somente enquanto força de trabalho para assegurar o lucro do empresariado. 0 contexto socioeconômico, político e social dos anos 80, principalmente nos anos finais dessa década, marcados pela defesa de um estado democrático e pelo estabelecimento de um cenário que enfatizava transformações na área da educação, com a democratização do ensino e da escola, tendo como foco o discurso sobre a gestão escolar, ganha força com o processo de anistia e com o movimento das "diretas já" que entre outras coisas, acende a chama da democracia e a educação aparece com uma das principais bandeiras de luta daqueles que exigiam mudanças no perfil político-administrativo brasileiro. No início dos anos 90, o discurso da gestão democrática avançava como modelo de gestão político-pedagógico e administrativo, que é orientada por processos de participação das comunidades local e da escola. 0 processo de democratização tornou-se fundamental visando melhores resultados em decorrência da descentralização do poder exercido pelo governo, que impunha condições ao gestor da escola se eximindo das responsabilidades que resultava em negligência e incompetência do gestor que era um mero preposto do governo. 2.2 Organização e gestão da educação no Brasil A gestão educacional de acordo com a Constituição Federal (1988) e a Lei de Diretrizes e Bases da Educação-LDB (1996), está voltada para a organização dos sistemas de ensino federal, estadual e municipal, assim como, das incumbências da União, Estados e dos Municípios, articulando entre as diferentes instâncias normativas, deliberativas e executivas as formas e os meios de oferta da educação escolar pelo setor público e privado. Na Constituição FederalCF (Art. 206, inciso VI) a "gestão democrática do ensino público, na forma da lei" aparece como um de seus princípios fundamentais à democratização da educação e na Lei de Diretrizes e Bases da Educação (LDB) de 1996, vem reforçar esse princípio, acrescentando apenas "e a legislação do sistema de ensino" (Art. 3o, Inc. VIII). A partir de então, o tema se tornou um dos mais discutidos entre os estudiosos da área educacional. Quanto a educação na esfera pública é tarefa compartilhada entre a União, os Estados, o 
Distrito Federal e os Municípios em regime de colaboração. Aparecendo no Título IV que fala da organização da educação nacional e seus artigos diversos, como tarefa da União, Estados e Municípios a organização da educação no Brasil, inclusive no que tange a organização, recursos e papel de cada ente federado. 2.2.1 A gestão da educação: considerações sobre a realidade observada A gestão educacional é composta de diferentes instâncias de governo, seja nas responsabilidades ou em suas especificidades de atuação. Portanto, situa-se na esfera macro, enquanto que a gestão escolar na esfera micro, ela só existe por causa da escola e do trabalho nela desenvolvida. Na presente análise, centrou-se a tenção sobre a gestão escolar, tendo em vista as limitações de tempo, o percurso percorrido durante a pesquisa e a vivência baseada na prática. Quanto a visualização da prática da gestão escolar, utilizou-se o espaço surgido no estágio supervisionado, onde foram feitas observações, procurando estabelecer um comparativo entre a teoria vivenciada na universidade e a gestão escolar, tendo como locus de concretização da pesquisa escolas públicas municipais que são utilizadas como campo de estágio supervisionado em gestão educacional. (83) 3322.3222 contato@conedu.com.br www.conedu.com.br Este estudo, não se configurou como um estudo de caso, pois a validade das informações obtidas nas observações seguiram as determinações da pesquisa qualitativa, expressa nas suas diversas técnicas de análise, cujo objetivo maior foi conhecer a natureza do fenômeno atentando do particular para o geral. A priori, a análise de natureza qualitativa, foi extremamente representativa para responder as indagações no que diz respeito a gestão escolar, mesmo que tenha-se utilizado outros elementos que sejam voltados para quantificação. Nesse sentido, verificou-se que: A abordagem qualitativa de um problema, além de ser uma opção do investigador, justifica-se, sobretudo, por ser uma forma adequada para entender a natureza de um fenômeno social. Tanto assim é que existem problemas que podem ser investigados por meio de metodologia quantitativa, e há outros que exigem diferentes enfoques e, consequentemente, uma metodologia de conotação qualitativa. (RICHARDSON: 1999, 79). Segundo alguns autores, como: PARO (2000), LIBÂNEO (2008) e LÜCK (2009), a gestão escolar refere-se a organização dos estabelecimentos de ensino e tem por finalidade, promover o ensino e a aprendizagem, fazendo com que a educação seja um direito de todos, em conformidade o que diz a Constituição e a Lei de Diretrizes e Bases da Educação. 0 sistema educacional tem um conjunto de atividades que trata das politicas educativas, tais como: o planejamento, o acompanhamento e a avaliação. Já no campo da gestão escolar estão aqueles com a tarefa de ensinar e aprender. Especificamente falando, situam-se professores, alunos e outros membros que compõem a comunidade escolar, como por exemplo: funcionários da escola, professores que ocupam cargos de gestores e famílias que integram a área onde se localiza a escola. É através da proposta pedagógica que a escola se norteia, definindo seus caminhos e rumos a serem seguidos para que a comunidade possa se integrar de maneira mais efetiva e ativa no processo educativo. Apesar de estudiosos e dos marcos legais da educação preconizarem a gestão escolar como um processo que deva ocorrer na escola de forma democrática, existem na gestão escolar problemas oriundos de práticas políticaseleitorais que impedem a sua democratização e impulsionam a concepção de uma gestão escolar baseada nos casuísmos eleitorais e em práticas autoritárias. 0 estabelecimento de uma gestão democrática na escola está vinculado aos mecanismos legais e institucionais e à coordenação de atitudes que propõem a participação social: no planejamento e elaboração de políticas educacionais; na tomada de decisões; na escolha do uso de recursos e prioridades de aquisição; na execução das resoluções colegiadas; nos períodos de avaliação da escola e da política educacional. Com a aplicação da política da universalização do ensino deve-se estabelecer como prioridade educacional a democratização do ingresso e a permanência do aluno na escola, assim como a garantia da qualidade social da educação. A gestão escolar democrática só passa a ser efetivada na medida em que se estabelece uma gestão democrática da educação, definida "como uma das formas de superação do caráter centralizador, hierárquico e autoritário que a escola vem assumindo ao longo dos anos [...]" (Antunes: 2002:13). Portanto, a gestão democrática na escola é um dos caminhos mais importantes para se obter uma ótima qualidade na educação. Quanto mais participação por parte dos professores, alunos, da família e de toda a comunidade em geral, mais chances os alunos terão para aprender. Para que ela seja efetivada, os governantes devem permitir aos gestores escolares que sejam ministrados os recursos da área, assim como, prever a atual LDB. Foi pensando em uma educação pública de qualidade, que os trabalhadores da educação realizaram vários movimentos contribuindo para a democratização. Desta forma, garantir a participação de toda a comunidade, principalmente dos estudantes, na gestão democrática é condição indispensável a concretização/implantação de práticas democráticas na escola. Neste sentido, é preciso, [...] uma permanente participação popular nas decisões da coisa pública, da criação de um novo senso comum que substitua os velhos princípios tayloristas e fordistas por novos princípios e novas práticas participativas de administração. (BASTOS: 2005, pg. 8) Com uma participação efetiva da comunidade, a educação deixa aquele status de autoritária e hierárquica, passando a uma educação democrática. É de fundamental importância à participação da comunidade na elaboração do projeto politico pedagógico da escola, é por 
este que a escola se norteará em suas ações e trabalhos por ela realizados. Como pode-se observar no artigo 14 da Lei de Diretrizes e Bases da Educação Nacional - 9394/96: Os sistemas de ensino definirão as normas da gestão democrática do ensino público na educação básica, de acordo com as suas peculiaridades e conforme os seguintes princípios: I - participação dos profissionais da educação na elaboração do projeto pedagógico da escola; II - participação das comunidades escolar e local em conselhos escolares ou equivalentes (BRASIL:1996,26 ). Portanto, a participação de toda comunidade escolar nas decisões e no processo de desenvolvimento da escola é indispensável ao estabelecimento da gestão democrática no espaço escolar. No caso das escolas observadas, verificou-se que o estabelecimento de uma gestão escolar democrática inspira mudanças no âmbito político, pedagógico e administrativo da escola, exigindo inclusive novas posturas do gestor escolar. Para que obtenha sucesso em suas ações, o gestor deve observar que é preciso que todos os envolvidos estejam motivados, para que se obtenha um bom rendimento no processo educacional. É muito interessante e de grande valia no processo de execução das atividades que o diretor desenvolve que ele invista na capacitação dos profissionais. Para Lück (2004), na gestão participativa, os diretores devem dedicar uma grande parte do tempo na capacitação de profissionais, no desenvolvimento de um sistema de acompanhamento escolar e em experiências pedagógicas baseadas na reflexão-ação. É muito importante que se tenha gestores reflexivos que exerça um trabalho em equipe com os professores e demais participantes da escola em prol de um único objetivo, que é uma boa formação voltada ao aprendizado dos alunos. Nas escolas em pesquisadas, observou-se que o trabalho do gestor escolar está diretamente ligado a organização e gestão da escola, assumindo papéis diversos na organização escolar, tanto de natureza administrativa, como pedagógica. No âmbito administrativo, seu papel e atuação centra-se na articulação e controle dos recursos humanos, além de orientação e supervisão das atividades que delega à todos os seus subordinados, tornando-se uma tarefa extremamente árdua, pois gera muitas vezes conflitos na execução das atividades por ele delegadas. Na esfera pedagógica, seu trabalho centra-se, sobretudo, na preocupação com a aprendizagem dos discentes, procurando estimular e melhorar o desempenho de alunos e professores nas atividades didáticopedagógicas

\section{CONSIDERAÇÕES FINAIS}

O presente trabalho, oportunizou na prática, o observação de como estabelecer no contexto da escola pública um processo de gestão democrática, enfocando a relação entre a gestão escolar e o estabelecimento de práticas democráticas que conduzam a autonomia da escola. Nessa atmosfera de estabelecimento de um processo democrático na escola, chegou se a conclusão de que o gestor escolar deve assumir uma posição de liderança na escola, sem perder o poder de dialogar, deve assumir uma comunicação aberta, desenvolvendo credibilidade, cuidando sempre do relacionamento interpessoal de alunos, professores e pais, impulsionando com sua prática a participação de todos na gestão da escola. 0 envolvimento e liderança, necessariamente devem ser oferecidos dentro de uma linha de ação segundo a qual o diretor é um facilitador, alguém que pensa e assume responsabilidade de articular a equipe gestora, para assim desenvolver uma gestão integrada com todos os segmentos da escola, envolvendo também a participação da família. É de suma importância o acompanhamento do trabalho do gestor em relação a observação junto às demais repartições funcionais da Instituição de Ensino, um trabalho compartilhado, com estratégia onde o ensino e a aprendizagem sejam as molas mestras da gestão da escola. Assim, concluímos que a gestão da escola deve ter um caráter democrático, baseado na participação de todos os atores e atrizes sociais que compõem a comunidade escolar, buscando resolver juntos os problemas comuns à escola, buscando na luta e na participação social as soluções e respostas para os desafios do diaa-dia no contexto escolar.

\section{REFERÊNCIAS}

[1] Antunes, A. Aceita um conselho?- Como organizar o Colegiado Escolar. Guia da Escola Cidadão. São Paulo: Cortez/Instituto Paulo Freire, 2002.

[2] Aranha, Maria Lúcia Arruda. História da Educação e da pedagogia: Geral e do Brasil. 3. ed. São Paulo: Moderna, 2006.

[3] Bastos, João Baptista (Organizador). Gestão democrática. 4. ed. Rio de Janeiro: DP\&A: Sepe, 2005.

[4] Brasil. Constituição (1988). Constituição da República Federativa do Brasil: promulgada em 5 de outubro de 1988. 
[5] Brasil. LDB (1996). Lei de Diretrizes e Bases da Educação Nacional: promulgada em 20 de dezembro de 1996. BRASIL.

[6] Pne. (2000). Plano Nacional de Educação. Promulgado em15 de outubro de outubro de 2010.

[7] Cury, Carlos Roberto Jamil. A questão federativa e a educação escolar. In: Oliveira \& Santana, Romualdo Portela e Wagner (Organizadores). Educação e federalismo no Brasil: combater as desigualdades, garantir a diversidade. Brasília: Unesco, 2010.

[8] Dalberto, Maria Célia Borges. Neoliberalismo, Políticas Educacionais e a Gestão Democrática na Escola Pública de Qualidade. São Paulo: Paullus, 2009.

[9] Dourado, Luiz Fernandes (Organizador). Políticas e Gestão da Educação no Brasil: novos marcos regulatórios?. São Paulo: Xamã, 2009.

[10] Heidman \& Salm, Francisco G. e José Francisco (Organizadores). Políticas públicas e desenvolvimento: bases epistemológicas e modelos de análise. Brasília: Universidade de Brasília, 2009.

[11] Libâneo, José Carlos. Democratização da escola pública: a pedagogia crítico-social dos conteúdos. 22. ed. São Paulo: Loyola, 2008.

[12] Lourenço Filho, M. B. Introdução ao estudo da Escola Nova. São Paulo: Melhoramentos, 1978

[13] Lück, Heloísa. Dimensões da gestão escolar e suas competências. Curitiba: Editora Positivo, 2009.

[14] ___. Heloísa: Ação Integrada: Administração Supervisão e Orientação Educacional: 22. ed. Petrópolis 2004.

[15] Paro, Vitor Henrique. Qualidade do Ensino: a constituição dos pais. São Paulo: Xamã, 2000.

[16] Pimenta, Selma Garrido. Estágio e docência. São Paulo: Cortez, 2012.

[17] Richardson, Roberto Jarry. Pesquisa Social: métodos e técnicas. 3. ed. São Paulo: Atlas, 1999. Sposito, M. 0 povo vai à escola. São Paulo: Loyola, 1984. 


\title{
Capítulo 8
}

\section{Gestão democrática no colégio Tiradentes de Passo Fundo: Iniciativas e interpretações}

\author{
João Lair Alves \\ Eliara Zavieruka Levinski
}

Resumo: Este texto decorrente de pesquisa bibliográfica, consulta a documentos e observações, é um recorte do trabalho de conclusão do curso de Pós-Graduação Lato Sensu Gestão Escolar, concluído em 2014, na Faculdade Senac de Porto Alegre, tem como finalidade socializar e interpretar as iniciativas que estão constituindo, desde 2009, o processo de gestão democrática e consequentemente a identidade político - pedagógica do Colégio Tiradentes de Passo Fundo/RS (CTBMPF). A gestão democrática continua sendo um desafio nos espaços escolares e de sistemas, apesar do seu reconhecimento, aportes legais e permanentes estudos. 0 desafio é intensificado quando referimos esta vertente da gestão em uma instituição de ensino de natureza militar. Ao mesmo tempo, pode-se afirmar que é possível vivenciar no cotidiano da escola, a gestão democrática quando a decisão é feita de modo participativo. 0 princípio deste processo residiu na tomada de decisão coletiva que envolveu os segmentos (professores, pais, funcionários, alunos e militares) do CTBMPF com discussões, estudos e encaminhamentos sobre como o Colégio seria gestado nas dimensões administrativas, técnicas e pedagógicas. Diante de convicções e princípios foi decidido realizar um processo de gestão ancorado na participação, diálogo e autonomia. Para compreender esta trajetória durante a reflexão abordaremos questões relacionadas a gestão, ao contexto do Colégio e relataremos práticas pedagógicas que representam a gestão democrática. Várias iniciativas foram consolidando a gestão democrática, entre elas, o conselho de classe participativo que transformou-se em sistema de avaliação institucional e o programa de formação continuada de professores que entrelaçadamente com outras práticas pedagógicas, agregam qualidade e reafirmam as premissas que é possível no cotidiano da escola pública vivenciar processos de gestão democrática. Processos de natureza democrática contribuem para o rompimento da separação entre o pensar e o fazer e entre a teoria e a prática, como observa Veiga(1998).

Palavras-chave: Gestão democrática. Escola. Participação.

8 Texto apresentado e publicado nos Anais do XII EDUCERE III Seminário Internacional de Representações Sociais, Subjetividade e Educação - SIRSSE, V Seminário Internacional sobre Profissionalização Docente (SIPD/CÁTEDRA UNESCO) e o IX Encontro Nacional sobre Atendimento Escolar Hospitalar - ENAEH, Curitiba/PR, 2015 


\section{INTRODUÇÃO}

Este trabalho tem por objetivo socializar práticas pedagógicas que representam o processo de gestão democrática em desenvolvimento no Colégio Tiradentes de Passo Fundo desde o primeiro ano de existência (2009), associando-o às dificuldades, conquistas e desafios. Para tanto, busca-se subsídios na literatura, consulta-se documentos do Colégio e ilustra-se com a nossa vivência enquanto sujeitos participantes deste educandário desde 2010.

Um dos desafios históricos da Educação Básica em nosso país é a gestão democrática nas escolas públicas. A cada período da história da educação brasileira, novos avanços se efetivam no campo da gestão democrática, principalmente, através das políticas educacionais, pois é um dos indicadores da qualidade do ensino. Decidir por um processo de gestão democrática implica estar aberto para o diálogo, para a participação, para a transparência, para a descentralização do poder, para a escuta, pois conforme as palavras de Lück (2006, p. 33), "Escola democrática é aquela em que os seus participantes estão coletivamente organizados e compromissados com a promoção de educação de qualidade para todos".

Salienta-se a previsão do Plano Nacional de Educação, o qual tratadas escolas públicas no nosso país, (em seu Art. 9o9), referindo-se que os Estados, o Distrito Federal e os Municípios deverão aprovar leis específicas para os seus sistemas de ensino, disciplinando a gestão democrática da educação pública nos respectivos âmbitos de atuação, no prazo de 2(dois) anos, contados da publicação desta Lei, adequando, quando for o caso, a legislação local já adotada com essa finalidade.

Com esta perspectiva, o Colégio Tiradentes de Passo Fundo, desde seu princípio (2009), está desenvolvendo projetos e ações que procuram materializar o processo de gestão democrática no currículo escolar. As atividades de ensino são desenvolvidas de acordo com a Lei de Diretrizes e Bases da Educação Nacional e com a Lei de Ensino da Brigada Militar, em conjunto com as demais leis vigentes, bem como baseadas nos documentos de ensino que norteiam o colégio, Regimento Escolar, projeto políticopedagógicos e planos de estudo.

Com o intuito de buscar a excelência no ensino, desde o seu princípio, buscou-se por decisão políticopedagógica a construção participativa do processo educativo desta instituição. Um dos pilares desta opção foi envolver todos os segmentos do Colégio Tiradentes no processo de pensar, debater, fazer e avaliar o trabalho educativo, pois como afirma Freire (1989), a participação de todos na escola, para aprender a exercitar a democracia reafirma a sua definição para a educação popular.

Entre as muitas representações da gestão democrática em ação, destaca-se o conselho de classe participativo, em vigor desde 2009, que se apresenta e se consolida como sistema de avaliação institucional e o programa de formação continuada dos segmentos da escola. Deste modo, o presente trabalho estará estruturado por reflexões acerca da gestão escolar, gestão democrática, contexto do colégio Tiradentes, acervo da LBD 9496/96 e do Plano Nacional de Educação e das representações democráticas da gestão com suas características, limites e desafios.

\section{SITUANDO E INTERPRETANDO A TEMÁTICA DE GESTÃO E GESTÃO DEMOCRÁTICA}

\subsection{CONCEPÇÃO DE GESTÃO}

O conceito de gestão foi conhecido ainda com o surgimento da revolução industrial, quando os profissionais passaram a buscar soluções para os diversos problemas que na época existiam, usando métodos que conheciam para administrar os negócios, de forma que, com esse tipo de administração que era aplicada, dever-se-ia obter bons resultados.

Para exercer a administração é necessário o conhecimento e aplicação de modelos e técnicas administrativas, fazendo valer as funções do gestor. Evidencia-se a necessidade de fixar metas, fazer planejamento, analisar e conhecer os problemas a enfrentar, solucionar esses problemas, organizar recursos financeiros, humanos e tecnológicos, ser um comunicador, um líder ao dirigir as pessoas, tomar decisões precisas, avaliar e controlar o conjunto num todo, sem se preocupar muito com o estado geral das pessoas que estavam sob seus cuidados.

Quando se fala em gestão de pessoas, não se pode pensar que esta é uma realidade que sempre existiu, nem sempre se pensava nas pessoas como sujeitos de uma organização. Na perspectiva da Administração Científica, pelas palavras de Amboni e Andrade (2009), percebe-se a preocupação em realizar planejamento e se aplicar métodos científicos no desenvolvimento dos trabalhos, fazendo com que os 
operários se tornassem cada vez mais experientes naquilo que faziam, realizando, assim, de modo mais rápido e eficiente a produção.

Nesta linha os desejos e objetivos do trabalhador não eram observados, eram considerados como máquinas e consequentemente não se sentiam motivados para realizar o trabalho. Por isso, a administração científica se fundamentava na racionalização do trabalho, objetivando reduzir tempos e gastos.

Já em outra perspectiva, o termo gestão tem sua raiz etimológica em ger, que significa fazer brotar, germinar, fazer nascer. Da mesma raiz provêm os termos: genitora, genitor, germen. Neste viés, Levinski (2000), destaca que a gestão é um fenômeno político, de construção de projetos/idéias, de fazer opções, de decidir quanto a regras de convivência. Ainda, Lück (2006, p. 109), afirma que "ao se adotar o conceito de gestão, assume-se uma mudança de concepção a respeito da realidade e do modo de compreendê-la e de nela atuar".

A gestão democrática tem como fundamento inicial a descentralização da educação, que decorre do entendimento de que a democracia deve ser praticada na perspectiva da democratização da sociedade.

A democracia constitui-se em característica fundamental de sociedades e grupos centrados na prática dos direitos humanos, por reconhecerem não apenas o direito das pessoas usufruírem dos bens e dos serviços produzidos, mas, sobretudo, o direito e dever de assumir responsabilidade pela produção e pela melhoria desses bens e serviços. Estabelece-se a verdadeira democracia construída mediante participação qualificada pela cidadania e construção do bem comum.

No contexto das sociedades e organizações democráticas, dado o seu caráter dinâmico e participativo, direito e dever são conceitos que se desdobram e se transformam de forma contínua e recíproca pela própria prática democrática, que é participativa, aberta, flexível e criativa. Portanto, não são conceitos que representam condições isoladas e dissociadas. Não se trata, portanto, de um sentido normativo e imperativo de direitos e deveres e sim de um sentido interativo pelo qual se transformam continuamente e são superados por estágios sucessivos de complexidade que vão tornando mais amplas, complexas e significativas as funções sociais do grupo, ao mesmo tempo em que seus membros vão desenvolvendo a consciência do processo como um todo e de seus múltiplos desdobramentos. Vai-se criando no interior da escola uma cultura própria orientada pela realização dos ideais da educação, que passam a fazer parte natural do modo de ser e de fazer da escola e, por isso mesmo, não precisa ser imposta de fora para dentro.

A participação constitui uma forma significativa de, ao promover maior aproximação entre os membros da escola, reduzir desigualdades entre eles. Portanto, a participação está centrada na busca de formas mais democráticas de promover a gestão de uma unidade social. As oportunidades de participação se justificam e se explicam, em decorrência, como uma íntima interação entre direitos e deveres, marcados pela responsabilidade social e valores compartilhados e o esforço conjunto para a realização de objetivos educacionais.

Nesse sentido, a gestão democrática escolar é exercida tanto como condição criadora das qualificações necessárias para o desenvolvimento de competências e habilidades específicas do aluno, como também para a criação de um ambiente participativo de vivência democrática, pela qual os alunos desenvolvem o espírito e experiência de cidadania, caracterizados pela consciência de direitos em associação a deveres.

Vale dizer que todos os processos e ações participativos promovidos pela escola somente se justificam na medida em que sejam orientados para qualificar o processo de ensinar e de aprender.

\subsection{APORTES DA LEGISLAÇÃO}

A Constituição Federal de 1988 foi um importante marco para a democratização da educação. A Constituição cidadã reforçou o movimento de gestão democrática da educação que teve um grande avanço nas décadas de 80 até meados da década de 90, quando foi, então, promulgada a atual Lei de Diretrizes e Bases da Educação Nacional (Lei 9394/96) - LDB, que contemplou em seus artigos, 12, 14 e 15 os princípios norteadores da gestão democrática. Observa-se também que esta perspectiva também está presente no Plano Nacional de Educação - PNE.

O desafio da gestão democrática nas escolas públicas ainda, em muitas realidades, encontra-se distante e abstrato do que a lei estabelece. Sabe-se que nos discursos existe o reconhecimento da necessidade e valor deste processo democrático nas escolas. Ao mesmo tempo, isto implica em tomar decisões querem e tem a 
concepções de sociedade, de mundo, de pessoa, de ensino, entre outras categorias e, consequentemente, na organização de um projeto e ações que revelam coerência no cotidiano das escolas. Projetos desta natureza redefinem projetos de sociedade. A legitimidade de processos que inscrevem a gestão democrática reside primeiramente na decisão de constituir um projeto com base em princípios e conceitos da democracia, a exemplo da participação, autonomia, diálogo, descentralização do poder, reflexão sobre a ação, entre outros.

É preciso ter a coragem para começar como muitos dizem. Foi com coragem, vontade e convicção que em 2009, no berço do colégio Tiradentes de Passo Fundo, o coletivo da época, assumiu o compromisso de processualmente construir um currículo transversalizado pela gestão democrática. Para muitos, esta decisão foi compreendida como contraditória por ser um educandário com característica e base militar.

0 percurso foi indicando que a gestão democrática quando vivida intensamente no movimento da cotidianidade causa apreensão, exige pertencimento, domínio teórico, paciência, muito trabalho e permanente reflexão sobre o que está sendo realizado diante dos princípios que ancoram a gestão democrática inovadora de conhecimentos buscados e atualizados durante a gestão de comandante. Aberto ao diálogo, à reflexão crítica entre a teoria e a prática, esforçado na busca de conhecimentos e ao aperfeiçoamento daqueles adquiridos ao longo de sua trajetória na carreira militar, colabora para o desenvolvimento das atividades cotidianas, possibilitando um trabalho bem qualificado.

A gestão democrática demanda para a sua operacionalização, segundo Luce e Medeiros (2006, p. 22). "um conjunto de instrumentos e medidas que, no encontro com o já-vivido nas escolas, nas redes e nos sistemas de ensino, vai configurando as possibilidades de cada local".

\section{INICIATIVAS PEDAGÓGICAS DA GESTÃO DEMOCRÁTICA}

\subsection{REFERÊNCIAS SOBRE O COLÉGIO TIRADENTES}

o Colégio Tiradentes de Passo Fundo tem como unidade mãe o Colégio Tiradentes de Porto Alegre, o qual está em funcionamento por mais de 33 anos, sendo que, inicialmente, frequentavam as aulas somente pessoas do gênero masculino, de modo que um dos objetivos à época era preparar o aluno para o oficialato, seguindo carreira na Brigada Militar.

Sua instalação se concretizou com a assinatura do decreto de criação e instalação no dia 13 de dezembro de 2006, decretos estaduais de no 44.486 e 44.787, porém iniciou suas atividades cumprindo as exigências do Conselho Estadual em fevereiro de 2009.

o Colégio Tiradentes de Passo Fundo é um Órgão de Ensino da Brigada Militar, subordinado ao Departamento de Ensino. O Comando é exercido por um Oficial, no posto de Major, designado pelo Comando-Geral. O Corpo Docente é composto por professores oriundos da Secretaria Estadual de Educação, podendo ter instrutores da Brigada Militar, devidamente nomeados. As atividades de ensino são desenvolvidas de acordo com a Lei de Diretrizes e Bases da Educação Nacional e com a Lei de Ensino da Brigada Militar, em conjunto com as demais leis vigentes, bem como baseadas nos documentos de ensino que norteiam o colégio, regimento escolar, projeto político-pedagógicos e planos de estudo que revelam a identidade curricular. Além das disciplinas previstas pela legislação Federal, o Colégio Tiradentes de Passo Fundo oferece ao seu aluno uma série de atividades extras, que visam à formação de um cidadão consciente de seus direitos e deveres, bem como proporcionam a construção de competências e de habilidades para a educação integral do sujeito.

Aprender a viver juntos, a viver com outras pessoas, especialmente para os adolescentes, é sem dúvida alguma uma grande aprendizagem, um grande desafio da atualidade, uma vez que o mundo atual está repleto de contradições e desafios gerados pelo próprio movimento da sociedade.

o Colégio Tiradentes de Passo Fundo, orientado pela concepção de que a instituição escola possui a função social de formação integral do sujeito e de socializar o conhecimento que historicamente a humanidade acumulou, impregna-se de saberes e fazeres para consolidar este compromisso através de diferentes movimentos e projetos. A escola como formadora de sujeitos históricos, precisa ser um espaço de sociabilidade que possibilite a construção e a socialização do conhecimento produzido. A função social da educação e da escola implica problematizar a escola que se tem, na tentativa de construir-se a escola que se quer. 


\subsection{GESTÃO DEMOCRÁTICA NO COLÉGIO TIRADENTES DE PASSO FUNDO}

Fazer a gestão de uma instituição de ensino militar de nível médio tem sido um desafio permanente para o Comandante do Colégio Tiradentes de Passo Fundo, considerando a comunidade escolar constituída de jovens na faixa etária de 13 a 17 anos, funcionários, professores, pais e militares, observando ao princípios, as crenças e os ideais da perspectiva democrática da educação.

Analisando os fatores supra, busca-se responder às questões elencadas por meio de fundamentos e linhas teóricas, aperfeiçoando a busca do sucesso dos egressos do Colégio Tiradentes, a qual já é notória nos diversos cursos superiores. Salienta-se que mais de $85 \%$ dos ex-alunos estão frequentando as diversas universidades do estado do Rio Grande do Sul e de outros estados da federação.

A gestão democrática colabora para os bons resultados. A adequação da postura do gestor, profissional que se vê no centro da administração como um líder na perspectiva de uma gestão democrática e participativa, é o objetivo geral desse trabalho, o qual pretende ampliar a visão de liderança na instituição escolar militar de ensino médio, que apresenta um cenário de 30\% dos alunos serem dependentes de Militares e $70 \%$ pertencerem a comunidade em geral, das diversas cidades da região norte do estado do Rio Grande do Sul.

A liderança do gestor na gestão escolar democrática é formada pelo Comandante, que exerce a liderança e coordena todos os integrantes de diversos setores, desde a coordenação pedagógica, passando pela orientação educacional e os setores que tem como chefia os militares, sendo necessário praticar gestão de uma forma democrática e compartilhada, ou seja, uma liderança exercida em conjunto e com responsabilidade sobre os resultados da escola.

Para isso, é importante haver um entendimento entre todos os profissionais que trabalham na unidade de ensino. Num sentido mais amplo, a gestão democrática envolve militares, professores, alunos, funcionários e pais de alunos. É uma maneira mais aberta de dirigir a instituição. Para isso funcionar, é preciso que todos os envolvidos assumam e compartilhem responsabilidades nas múltiplas áreas de atuação da escola. Num contexto como esse, as pessoas têm liberdade de atuar e intervir e, por isso, se sentem à vontade para criar e propor soluções para os diversos problemas que surgem.

Nesta mesma linha, pode-se afirmar que a liderança também é desenvolvida nos alunos, colocada em prática desde o primeiro ano, como chefe de turma e aluno semana, até quando frequentam o $3^{\circ}$ ano, quando as funções de comando são diversas eles passam a serem mais respeitados, de certa forma, pelos demais alunos do $2^{\underline{a}}$ e $1^{0}$ anos. A liderança é inerente à dinâmica que envolve ensino e aprendizagem, além de oferecer ensino de qualidade, é obrigação da escola fazer com que eles se sintam parte integrante do processo educacional e participantes de uma comunidade de aprendizagem, o que só se consegue com uma metodologia participativa, sempre sob a orientação do professor ou dos servidores militares, quando os alunos estiverem exercendo função de comando.

A liderança pressupõe a aceitação das pessoas, aprendizes com relação a uma influência exercida por aqueles que os ensinam, ela corresponde, portanto, a uma prática que depende muito da democracia para ser bem sucedida.

\subsection{CONSELHO DE CLASSE PARTICIPATIVO E FORMAÇÃO CONTINUADA DE PROFESSORES}

Nesta parte do artigo, pretende-se apresentar e refletir sobre algumas iniciativas que demarcam a identidade do Colégio Tiradentes de Passo Fundo, construídas por muitos em diferentes momentos da trajetória.

Centrar-se-á a reflexão em duas iniciativas: conselho de classe participativo e programa de formação continuada de professores.

a) Conselho de classe participativo:

O conselho de classe carrega historicamente uma visão de "júri", isto é, aluno por aluno é foco dos professores em reunião para remeterem pareceres sobre o desempenho, centrandoexcessivamente a análise no comportamento e atitudes. 
Rompendo com esta concepçâo tradicional e linear o colégio Tiradentes de Passo Fundo ancorou sua decisão na definição apresentada por Levinski:

É um instrumento de avaliação e está ancorado na perspectiva dialógica, reflexiva e investigativa, rompendo a concepção de que é um momento para "observar e julgar o outro", de mapear notas, comportamentos e problemas de determinados alunos. É o momento para os professores, alunos, militares, funcionários e gestores refletirem, debaterem o processo em ação na relação com as finalidades da educação e com projeto pedagógico, encaminhar propostas e estabelecer acordos que orientarão as ações posteriores. Caracteriza-se como um espaço democrático de construção de alternativas para o desenvolvimento da escola e das estratégias para o atendimento aos que nela estuda. Também com o conselho de classe pretende-se compartilhar informações sobre as aulas para embasar a tomada de decisões na melhoria do processo ensino-aprendizagem (2000, p. 6).

Nesta perspectiva a participação é uma das categorias determinantes que orienta o conselho de classe, considerando que todos os segmentos são envolvidos no pensar, no falar, no fazer e no avaliar. Participar significa fazer parte, ser parte. A experiência está em ação desde 2009, sendo inicialmente tímida, mas com o passar dos anos congregou aspectos que hoje estão consolidados no processo pedagógico.

É um trabalho exigente e envolve muitos atores na sua efetivação. Muitas vezes o cotidiano do Colégio provoca o abandono do processo, especialmente pelas exigências externas e burocráticas. Mas simultaneamente às inúmeras atividades que fazem parte do ofício da escola, há a efetiva materialização do conselho.

O conselho de classe participativo neste tempo somou indicadores para tornar-se Sistema de Avaliação Institucional, visto que as dimensões pedagógica, adminsitrativa e técnica são objeto de apreciaçãoe posterior definição de objetivos, metas e estratégias.

O processo do conselho de classe envolve os seguintes momentos: encontro com cada segmento (pais, alunos, professores, gestão) para socializar os objetivos, sentido, organização e propostas para o conselho de classe; eleição de pais e alunos representantes no processo do conselho de classe; reflexão e registro sobre as práticas em ação que cada segmento concretiza no processo educativo, por meio de um instrumentoorientativo; sistematização das reflexões de cada segmento envolvido para apresentar e discutir em uma das sessões do conselho de classe e sessão com os segmentos para discutir e encaminhar propostas.

Nesta, cada segmento socializa os registros e os participantes discutem as questões fundantes e estabelecem acordos para o trimestre seguinte. Após, os acordos retornam para todos com o objetivo de qualificar o projeto e as práticas que são desenvolvidas pelos segmentos do Colégio. Em outra sessão, os professores e gestores (direção, coordenação pedagógica e orientação educacional) analisam, especificamente, as trajetórias de aprendizagem e de ensino no conjunto do processo educativo escolar. No conselho de classe seguinte, a reflexão estará ancorada nos acordos e encaminhamentos apresentados pelo conselho anterior.

Assim pode-se afirmar através das palavras de Levinski que:

O conselho de classe participativo no Colégio Tiradentes de Passo Fundo, é uma prática principiante sujeita a aperfeiçoamentos e revela a possibilidade de vivenciar a gestão democrática. Ao mesmo tempo, está constituindo um processo de formação dos sujeitos ratificando o protagonismo de cada um no coletivo da escola, colaborando para a interlocução entre os segmentos da comunidade escolar e para a qualificação dos processos de ensinar e de aprender. $(2000, \mathrm{p}, 24)$

b) Programa de formação continuada para professores

Constata-se que, permanentemente, a ação profissional necessita de ressignificação para atender o ofício de ensinar. Observa-se que, por um período significativo da educação brasileira, a formação continuada tentou suprir limitações da formação inicial. Os professores manifestavamdespreparo para heterogeneidade social e cultural, não dispunham de uma visão teórica amplae aprofundada sobre a prática pedagógica e tampouco da realidade escolar. 
As abordagens da formação continuada nas instituições de ensino, de modo geral,estão associadas aos projetos pedagógicos em ação. Independentemente dos princípios e pressupostos, têm o objetivo de aproximar os professores das discussões teóricas atuais docampo educacional e de aperfeiçoar as práticas em ação para qualificar os processoseducativos.

De acordo com Levinski (2013), a formação continuada dos professores, enquanto processo, é compreendida como um sustentáculo da qualificação e ressignificação das práticas acadêmicas e, quando congregada em um programa, necessita de um viés articulador que atravesse intenções, metas e ações.

Muitos estudos e debates indicam a prática pedagógica refletida e investigada como objeto fundamental na formação continuada. Levinski (2008) observa que, ao investigar reflexivamente as práticas em ação, os docentes têm a possibilidade de compreendê-las e ressignificá-las no conjunto das situações, bem como de buscar alternativas para as inquietações de qualificar o processo de ensinar e de aprender, e de dar-se conta mais intensamente do compromisso político-pedagógico da profissão docente.

Para Levinski (2013) o programa de formação continuada com base nas convicções, nas condições reais, nas avaliações, nas necessidades e nos indicadores metodológicos, ancora e articula um conjunto de ações, que destacamos a seguir:

a) Encontros pedagógicos

Os encontros que são realizados quinzenalmente, reúnem os professores, grupo dinamizador, coordenadores dos setores do Colégio. Têm como finalidade debater, analisar, aprofundar, decidir e encaminhar questões fundantes e alinhavadoras do processo pedagógico, além de ampliar os saberes acerca das políticas educacionais, da profissão docente e de pesquisas que despontam para aperfeiçoar a educação. 0 tempo é organizado para socializar e interpretar o cotidiano da sala de aula.

b) Seminários de atualização com outras escolas

Com outras instituições o Colégio planeja seminários e cursos. Os representantes das escolas, a partir da sua realidade, planejam conjuntamente as abordagens, a metodologia, as datas e a avaliação. Há profissionais que são convidados para palestras e oficinas, como também os professores socializam práticas pedagógicas que desenvolvem nos espaços de trabalho.

c) Eventos científicos

A participação em eventos educacionais é fundamental para aprofundar estudos e discussões, socializar e discutir as experiências do processo e conhecer práticas que são desenvolvidas em outros lugares e por outros protagonistas; possibilita ao participante observar e refletir o processo sob diferentes olhares, ultrapassando a leitura dos que estão envolvidos diretamente, e diminui o risco de cristalizá-los e isolá-los no local. Há professores que elaboram e submetem trabalhos sobre as práticas pedagógicas para serem apresentados e publicados em eventos de diferentes âmbitos. A gestão apoia e cria condições para o professor participar.

d) Seminários sobre obras eleitas

No final de cada ano letivo no seminário "Avaliando o ano e planejando o ano seguinte", a partir de indicadores, o coletivo de professores elege uma obra e diversos textos para serem estudados e debatidos no próximo ano, deixando em aberto para outras possibilidades. Geralmente as obras e textos selecionados possuem relação com a temática orientadora da prática investigativa. Os estudos são socializados e debatidos em seminário agendado no calendário letivo. Os núcleos fundantes colaboram para explicitação de dúvidas, para reafirmação de ações e para embasamento de decisões políticopedagógicas do processo escolar.

e) Registro e publicação de práticas pedagógicas

Os professores são desafiados para registrarem e publicarem sobre suas reflexões e práticas. Os textos quando representam o processo pedagógico do Colégio e derivam de debates e acordos do coletivo, passam fazer parte do projeto político-pedagógico. Há publicações de professores no blog do Colégio, em periódicos locais e anais de eventos.

Cabe ressaltar que o programa de formação continuada realizado aos profissionais que atuam em sala de aula do Colégio Tiradentes de Passo Fundo, os quais são conduzidos e orientados a cerca do aperfeiçoamento de seus conhecimentos e da melhoria na qualidade do ensino, o que vem contribuindo para os bons resultados obtidos pelos atuais alunos e pelos egressos seja notório. 


\section{CONSIDERAÇÕES FINAIS}

Procurou-se mostrar com este trabalho que a prática da gestão democrática implantada no Colégio Tiradentes de Passo Fundo está em pleno desenvolvimento. De um modo geral, leva-nos a crer que se está no caminho certo, pois as idéias são socializadas e refletidas entre os integrantes da comunidade escolar e são aplicadas através de instrumentos educacionais, como conselho de classe participativo, oportunidade em que os resultados serão verificados e os indicadores obtidos servirão como parâmetro para ressignificar as práticas pedagógicas do colégio. Sabendo-se que os processos educacionais são complexos, mas que o investimento no programa de formação continuada dos professores tem trazido ótimos resultados, assim, conclui-se que além da busca da satisfação, a gestão democrática é uma perspectiva que desponta na qualidade do ensino, considerando os indicadores internos e externos do processo ensinoaprendizagem.

As práticas escolares orientadas pela participação apontam diferenças positivas no processo de gestão administrativa, técnica e pedagógica do Colégio. O sucesso é alcançado, tornando-se notório o envolvimento coletivo dos segmentos em prol dos objetivos e princíos da educação e da escola.

É importante salientar que a prática de conselho de classe participativo e a formação continuada dos professores contribuem de forma siginificativa para o aprimoramento de um trabalho coletivo, envolvendo todos os segmentos do colégio nas tomadas de decisões, assim como na elaboração e execução de ações que visam solucionar ou diminuir as dificuldades as em prol da qualidade do ensino, cujo alicerce se firma na gestão democrática e participativa.

Observa-se também que o processo de gestão democrática no Colégio promoveu muitos debates, estudos e reflexões sobre a própria formação e práticas pedagógicas dos servidores militares, constituindo avanços na forma de dinamizar o processo escolar.

Cabe ressaltar que o comandar democraticamente fez com que todos os profissionais que atuam em sala de aula e segmentos do Colégio Tiradentes de Passo Fundo se envolvessem com os programas de formação continuada e no conselho de classe participativo. Desta forma, foram bem conduzidos e orientados acerca do aperfeiçoamento de seus conhecimentos e da melhoria na qualidade do ensino, o que vem contribuindo para os bons resultados obtidos, na escola, em vestibulares, em concursos e outras participações, pelos atuais alunos e pelos egressos do Colégio, trazendo a satisfação plena para quem participa do processo de ensinoaprendizagem.

\section{REFERÊNCIAS}

[1] Amboni, Nério; Andrade, Rui Otávio Bernardes. Teoria Geral da Administração. Rio de Janeiro, Elsevier, 2009.

[2] Brasil. Presidência da República. Lei no. 9.394 de 20 de dezembro de 1996 - Estabelece as Diretrizes e Bases da Educação Nacional. Publicada no Diário Oficial de 23 de dezembro de 1996. Disponível em http://www.mec.gov.br/legis/default/shtm. Acesso em 22.05.2008.

[3] Freire, Paulo. Educação como prática da liberdade, 19ạ Ed, Rio de Janeiro: Paz e Terra, 1989.

[4] Levinski, Eliara Z. Projeto político-pedagógico: obstáculos e possibilidades na prática de um processo participativo. 2000. Dissertação (Mestrado em Educação) Universidade de Passo Fundo, Passo Fundo, 2000.

[5] Levinski, Eliara Z. A dimensão político-pedagógica do processo participativo no ensino público municipal de Getúlio Vargas-RS. 2008. Tese (Doutorado em Educação). Universidade Federal do Rio Grande do Sul, Porto Alegre, 2008.

[6] _. Programa de formação continuada no Colégio Tiradentes: decisão, concepção e práticas. XI Congresso Brasileiro de Educação - Educere. PUC/PR, 2013.

[7] Colégio Tiradentes: conselho de classe participativo. Revista Somando. Passo Fundo, p. 24-24, 2000.

[8] Luck, Heloísa. Série: Cadernos de Gestão. A gestão participativa na escola. Petrópolis, RJ: Vozes, 2006.

[9] Medeiros, Isabel Letícia Pedroso; Luce, Maria Beatriz. Gestão democrática na e da educação: concepções e vivências. Porto Alegre: Editora da Ufrgs, 2006.

[10] Veiga, Ilma Passos Alencastro. Projeto político-pedagógico da escola: uma construção coletiva. In: Veiga, Ilma Passos Alencastro (Org.). Projeto político-pedagógico da escola: uma construção possível. 5. ed. Campinas, SP: Papirus, 1998. 


\section{Capítulo 9}

\section{Gestão democrática e formação política no campo da educação profissional}

\section{Andrezza Maria Batista do Nascimento Tavares}

Ricardo Rodrigues Magalhães

Caroline Stéphanie Campos Arimatéia Magalhães

Resumo: Consciência democrática e crítica representa um aspecto central para a formação cidadã e emancipadora de sujeitos escolares. 0 objetivo do estudo é desenvolver revisão bibliográfica sobre a concepção de democracia e de participação como necessidades formativas no campo da educação profissional. Inspirados na perspectiva da filosofia da práxis, o estudo busca apontar que a escola de educação profissional amplia o grau de desenvolvimento de seus estudantes na medida em que prioriza intenções política e pedagógica que permitem a construção de consciências alicerçadas nos princípios da participação e da formação política a partir de diálogos que celebrem o trabalho como princípio educativo. 0 estudo propõe como questão norteadora a provocação: como entender e em que espaços institucionais os estudantes de educação profissional podem desenvolver suas consciências sobre participação e formação política? Metodologicamente, compreende pesquisa de natureza qualitativa e revisão da literatura. Conclui-se que a instituição que promove educação profissional, na medida em que realiza experiência próxima com a categoria trabalho, precisa ampliar as oportunidades de construção de conhecimento sobre a formação política e a participação dos estudantes. É necessário privilegiar oportunidades didáticas e curriculares (formais e não-formais) que estimulem o desenvolvimento humano crítico e participativo, numa perspectiva de educação profissional que seja capaz de preparar os jovens para alcançar o pensamento dialético, inclusive, com possibilidade de reflexividades sobre pluralidade, participação e diversidade (étnica, de gênero e de minorias). Esses conceitos são vetores que configuram a formação política emancipadora por meio da participação ativa dos estudantes.

Palavras-chave: Participação. Formação Política. Educação Profissional. 


\section{NOTAS INTRODUTÓRIAS SOBRE DEMOCRACIA}

A deia de democracia voltada para os cidadãos surgiu na Grécia Antiga, conforme indica a literatura hegemônica, porém, existem aspectos reducionistas em seu sentido inicial, pois mulheres, crianças, estrangeiros e escravos (maior parte da população) não eram reconhecidos como cidadãos do povo ${ }^{9}$, portanto não podiam expressar as suas intenções nos processos de decisões.

Com advento da formação do capitalismo, foi estabelecida uma democracia apenas formal, divergente dos princípios propagados para as classes subalternas. O capitalismo tornou possível "conceber uma 'democracia formal', um modo de igualdade civil coexistente com a desigualdade social e capaz de deixar intocadas as relações econômicas entre a 'elite' e a multidão trabalhadora" (WOOD, 2011, p. 184).

Abrem-se parênteses, para enxergar mais claramente a ação sublime e sorrateira do capitalismo, que Wood (2011) complementa afirmando que, na democracia capitalista, a separação entre a condição cívica e a posição de classe atuam em duas vertentes interrelacionadas: a posição socioeconômica, que não determina o direto à cidadania, sendo isso o democrático da democracia capitalista; e, como o poder do capitalismo de apropriar-se do trabalho excedente dos trabalhadores não depende da condição jurídica ou civil privilegiada, a igualdade civil não modifica diretamente nem altera significativamente a desigualdade de classes, e seria isso que limita a democracia no capitalismo.

Nessa perspectiva, Santos (2002a) diz que a lógica do capitalismo global é resultante de um longo processo histórico, que desde o século XV até a contemporaneidade, possuiu algumas facetas que assumiu vários nomes, a saber: "descobrimento, colonialismo, evangelização, escravatura, imperialismo, desenvolvimento e subdesenvolvimento, modernização e, por último, globalização." (SANTOS, 2002a, p. 16).

Com Bobbio (2000), retoma-se a discussão sobre democracia e apresentam-se as três principais características. A primeira, atribuir o poder de decisão, dos sujeitos chamados a tomar ou colaborar na tomada de decisões coletivas, a um número restrito de sujeitos. Salienta-se que não é possível incluir "todos" no processo democrático, porque, mesmo no mais perfeito regime, não votaria nem seria votado os sujeitos que não atingiram certos critérios, como por exemplo a idade. A segunda, quanto às modalidades de decisão, a democracia ampara-se na regra da maioria, sendo consideradas as decisões aprovadas pela maioria daqueles a quem compete tomar a decisão. E, por último, a terceira característica de que é necessário colocar os que são chamados a decidir diante de alternativas concretas e em condições de poder, escolhendo entre uma e outra.

Nesse contexto, pode-se inferir que a democracia da modernidade ocidental assenta-se na ideia de contrato social. Santos (2002b) diz que este contrato tem características inovadoras e traduz-se em formas de Estado e sociedade específicas. Segundo o mesmo autor, vive-se no Século XXI um período de crise profunda deste contrato social, no qual destaca-se a predominância dos processos de exclusão social sobre os de inclusão social, inerentes ao capitalismo.

\section{REFLEXÕES SOBRE PARTICIPAÇ̃̃O COMO MECANISMO DE FORMAÇÃO POLÍTICA}

Esta seção tem o objetivo de enfatizar o debate sobre o papel mediador que a formação política pode desempenhar na articulação entre participação política e educação profissional, discutindo a respeito das possibilidades de desempenho da atividade política nas diversas dimensões da vida do sujeito, compreendendo a realidade em seus múltiplos níveis no contexto das políticas e da luta pelo direito social.

O reconhecimento e a busca por uma educação pública, gratuita e de qualidade, aufere consenso entre os estudiosos da educação e ao ideário de "[...] uma escola 'ativista', uma escola voltada para a vida, renovaram as esperanças de que a paz social e o desenvolvimento integral poderiam ser conduzidos pela escola." (GADOTTI, 2012, p.89, grifos do autor).

Enfatiza-se que a educação é fundamental para a promoção das transformações na sociedade, mas não é o único meio que conduzirá esse importante processo. Essa ressalva visa não incorrer no erro do discurso salvacionista e ingênuo que considera a educação como redentora da humanidade. (MOURA, 2013).

9 Apenas os homens adultos livres e residentes podiam se reunir nas assembleias gerais, e por sua vez, ouvir os oradores e opinar a respeito das decisões coletivas (BOVERO, 2002). Por isso, fica evidente o caráter restritivo e elitista da participação do povo Grego na democracia, não obstante, destaca-se que havia resistência e inúmeros embates populares, assim, a lógica contraria o envolvimento indiscriminado de todos - do povo. 
Tendo em vista que o capitalismo gera, entre outras coisas, novas formas de dominação e de coerção fora do alcance dos instrumentos criados para controlar as formas tradicionais de poder político, que ele também reduz a ênfase na cidadania e o alcance da responsabilização democrática (WOOD, 2011), tornase imprescindível, diante dessa circunstância, formatar a escola para assumir uma educação que vise "[...] à formação do humano-histórico que se afirma como sujeito [...]" (PARO, 2011, p. 28).

Nessa perspectiva, Mészáros (2008) esclarece que se percebe uma íntima ligação entre os processos educacionais e os processos sociais mais abrangentes de reprodução. 0 autor acrescenta dizendo que uma reformulação expressiva da "educação é inconcebível sem a correspondente transformação do quadro social no qual as práticas educacionais da sociedade devem cumprir as suas vitais e historicamente importantes funções de mudança." (MÉSZÁROS, 2008, p. 25).

Gadotti (2012) reforça que "as guerras e as convulsões sociais no mundo todo mostraram o quanto era frágil a contribuição da escola e que a educação não oferecia nenhuma garantia de 'dias melhores"” (GADOTTI, 2012, p. 89, grifos do autor).

Por isso, defende-se, neste trabalho, que a transformação ${ }^{10}$ seja conduzida de forma ampla e sistemática, a partir das contradições e/ou vulnerabilidades ${ }^{11}$ do modo de produção vigente, envolvendo todos os segmentos da sociedade de modo a contribuir para compreensão da totalidade humana, enfatizando a autonomia e emancipação como meio para a ampliação da formação política dos estudantes na escola para resistir a lógica hegemônica, e, assim, consolidar uma educação "para além do capital", como propõe Mészáros (2008).

Para tanto, França e Silva (2012) advogam que o desenvolvimento de ações para reforçar a autonomia das escolas deve propiciar condições apropriadas para materialização da autonomia da comunidade escolar, objetivando que essa autonomia seja construída em cada instituição de ensino de acordo com as especificidades locais e em consonância com os princípios e finalidades a que se propõe a educação pública. É indispensável oferecer aos educadores ${ }^{12}$, aos estudantes e aos demais interessados da comunidade o acesso às informações necessárias à participação no processo de gestão e o espaço em comissões e/ou conselhos colegiados, para que os processos decisórios estejam pautados em ações coletivas e transparentes, fortalecendo a prática autônoma dos envolvidos, conforme preceitua a autonomia ${ }^{13}$.

Nesse ínterim, não há autonomia da escola sem o reconhecimento da autonomia dos indivíduos que a compõem. Ela é o resultado da ação concreta dos indivíduos que a constituem, no uso da autonomia relativa ${ }^{14}$.

Na contemporaneidade, a autonomia atribuída às escolas, reflete apenas a aparente ampliação dos espaços de decisão, caracterizada como uma ampliação controlada, imposta pelas normas e legislação, e descentralização financeira, que não garantem proporcionar condições reais de autonomia a todos os segmentos da escola e da comunidade (OLIVEIRA, 2006), pois são insuficientes para instituírem formas de autogoverno das escolas, uma vez que a autonomia não se dá por outorga, mas por processo de construção na relação entre os atores.

Apreende-se que precisam ser oferecidas as condições materiais concretas para o exercício da autonomia, caso contrário, notar-se-á somente a falácia da emancipação dos sujeitos, não permitindo que os estudantes se governem por si mesmo, contrário ao propósito único da autonomia (BARROSO, 2013).

\footnotetext{
10 Termo compreendido como sendo ruptura com a lógica capitalista.

${ }^{11}$ Reconhece -se como contradição e/ou vulnerabilidades do modo de produção capitalistas: o trabalho assalariado; a apropriação do trabalho; a tentativa de separar corpo e mente no labor; o parcelamento ou pormenorização do trabalho; a desqualificação; a lógica de lucrar da vez mais e remunerar o trabalhador cada vez menos, entre outros aspectos que direta ou indiretamente evoca espontaneamente o sentimento de injustiça e a consciência crítica da realidade dos indivíduos.

12 Compreendido neste trabalho como sendo todos os funcionários que desempenham suas tarefas no ambiente escolar.

13 Conceito descrito na seção secundária 4.1 deste trabalho.

14 De forma análoga, apropria-se da discussão das concepções de Poulantzas (2000) acerca da autonomia relativa do Estado para compreender o termo no contexto da escola, uma vez que seria reduzido não conceber a instituição escolar em meio aos conflitos conjunturais do Estado. Dessa forma, recomenda-se leitura da Obra “O Estado, o poder, o socialismo" do referido autor para aprofundamento da temática.
} 
Nesse contexto, Paro (2011) realça a discussão quando afirma que:

\begin{abstract}
Certamente, uma das questões mais espinhosas com que se defronta quando se trata de conceber uma educação escolar verdadeiramente democrática diz respeito à autonomia que deve caber aos educandos na escola. No ensino tradicional, em que o aluno é tido como mero receptor de conhecimento e informações, o assunto é facilmente resolvido com a aceitação de que às crianças cabe apenas obedecer àquilo que é estabelecido pelos adultos, estruturando-se a escola de modo a atender a esse mandamento (PARO, 2011, p. 178, grifo nosso).
\end{abstract}

Sendo assim, a formação que por fim conduziria a autonomia dos sujeitos precisa levar em conta as condições a que se encontram subordinadas a produção e a reprodução da vida humana em sociedade e na relação com a natureza. 0 poder das relações sociais é decisivo, face sofrer os efeitos dos estímulos espontâneas dos indivíduos, pois "[...] Marx e Freud desvendaram os determinantes da limitação do esclarecimento, da experiência do insucesso da humanização do mundo, da generalização da alienação e da dissolução da experiência formativa." (ADORNO, 1995, p. 19, grifo nosso).

Adorno (1995) relata que percebe que as relações sociais não interferem apenas nas condições da produção econômica e material, mas também interagem no plano da subjetividade, na qual surgem relações de dominação, as quais favorecem a naturalização de uma sociedade hierarquizada, que se reflete na formação política dos educandos e na gestão e organização escolar.

Para tanto, faz-se necessário consubstanciar uma democracia com a qual há o dever de não apenas operar o modo de produção capitalista, mas funcionar conforme preceitua os princípios da democracia participativa, nos moldes defendidos por Santos (2002a), demandando, portanto, preparar estudantes autônomos, com vistas ao cumprimento da democracia de alta intensidade, mas que só pode ser vislumbrada quando houver uma sociedade emancipada.

Por sua vez, em uma democracia em que funde-se na participação da coletividade, quem defende ideais contrários à autonomia, e, portanto, contrários à decisão consciente e independente de cada pessoa em particular, é avesso à democracia real. As perspectivas de concepções exteriores que não se originam a partir da consciência emancipada, por sua vez legitimada frente a essa consciência, deverão ser interpretadas como individualista e acrítica em relação ao capitalismo.

Para caminhar no sentido de formar indivíduos críticos e conscientes politicamente, faz-se necessário refletir acerca das diretrizes norteadoras desta formação (MANACORDA, 2007). Esse processo formativo, proposto pela pedagogia tradicional, conduz o indivíduo frente a si mesmo e não diretamente frente ao mundo concreto das coisas e das relações sociais, substituindo um processo educativo heterônimo por um processo autônomo, que é igualmente limitado (MANACORDA, 2007).

No dizer de Montaigne (2002), não se trata apenas de ter uma cabeça "bem cheia" de conhecimento, mas de ter uma "cabeça bem feita", ou seja, trata-se da formação da consciência humana sobre as bases que sustentam à fortaleza capitalista.

O processo de formação de classe cria uma instância identificável de transformação e as condições para conscientização da classe popular, conforme Petras (2010) diz que Marx e Engels "compreendiam que a transformação das condições econômicas e a organização das classes para a revolução socialista dependiam da educação e da prática política." (PETRAS, 2010, p. 240, grifo nosso). Nesse fragmento em destaque, em relação ao papel da educação e a prática política, percebe-se que ambas são premissas da transformação do projeto de sociedade à época, podendo ainda ser aplicável na contemporaneidade.

Concebendo sistematizar meios para construção de uma nova lógica social, torna-se relevante discutir as interferências na formação política dos estudantes em meio a um sistema democrático forjado, enxergando a escola como um aparelho ideológico do Estado, mas que, todavia, pode ser creditado como um meio propício que favorece a transformação da sociedade, podendo oportunizar que o estudante possa contrapor-se as imposições capitalistas.

Não obstante, salienta-se que este trabalho concebe que a formação e o exercício da prática política na escola, associada à educação de qualidade socialmente reconhecida, são premissas necessárias, que constituem um próspero caminho em direção à solidificação de uma sociedade mais justa e igualitária, compreendendo seu papel político inerente à atividade social, de modo a tornar possível a convivência entre os grupos e pessoas na produção da sua própria existência.

Entretanto, antes de alcançar a plenitude das mencionadas premissas, deve-se enfrentar uma realidade diversa. Nesse sentido, Paro (2011, p. 27) diz que existem duas formas de conduzir a convivência: I - pela 
dominação, que seria "uma prática política autoritária que reduz o outro à condição de objeto, à medida que anula ou diminui sua subjetividade e estabelece o poder de uns sobre outros."; ou pelo II - diálogo, sendo "a alternativa democrática de convivência política".

Evidentemente elege-se o diálogo como a maneira mais adequada, porém, ele se baseia na persuasão pelo diálogo que, preliminarmente, avalia-se como um importante avanço, mas que na realidade concreta, nas condições existentes, onde o dissenso é privilégio de poucos, o diálogo, teria o efeito inverso, o de negação.

Para afastar-se dessa visão de negação do diálogo, recorre-se à Freire (2011), pois se faz necessário “[...] reconhecer que somos seres condicionados, mas não determinados. Reconhecer que a história é tempo de possibilidade e não de determinismo, que o futuro, permita-se reiterar, é problemático e não inexorável." (FREIRE, 2011, p. 20, grifo do autor).

No entanto, essa visão fatalista de não abertura ao diálogo para promover a transformação social dos estudantes ainda existe, principalmente no âmbito escolar, porque nos espaços formais de educação, prevalece à transmissão de conhecimentos e conteúdos de alguém que sabe, o professor, para alguém que não sabe, desrespeitando o saber do estudante que chega à escola, lógica definida por Freire (2015) como sendo característica da educação bancária.

Dessa forma, infere-se que a consequência desse formato de educação limitado, que não considera a formação política dos estudantes, é resultado da existência da concepção de que "a escola não é partido. E ela não tem nada a ver com isso. Ela tem que ensinar os conteúdos, transferi-los aos alunos", perspectiva criticada por Freire (2011, p. 32).

Dentro dessa concepção, a educação demonstra seu caráter conflitante, não só por ser espaço político, inserido em uma sociedade contraditória e dividida em classes, mas também "enquanto se constitui num movimento contraditório (entre o saber e a ignorância)." (GADOTTI, 2012, p. 190).

Freire (2011, p. 58) teoriza que o "respeito à autonomia e à dignidade de cada um é um imperativo ético e não um favor que podemos ou não conceber uns aos outros.". Trata-se assim, de construir uma autonomia de fato e não de direito, garantindo a busca da formação de sujeitos coletivos, sendo necessário condições materiais para construção de uma nova cultura escolar.

Nessa direção, Mochcovitch (1990), afirma que é necessário proporcionar um conjunto de conceitos que possibilite pensar e orientar na prática a formação da consciência de classe trabalhadora, constituindo um projeto alternativo de sociedade mediado pela ação política e pela elevação cultural das massas, não admitindo a naturalização de um conformismo imposto.

Ressalta que um sujeito humano separado de sua classe social e estranho às lutas entre as classes não é concebível, pois "é no interior das lutas, na forma em que modernamente se desenvolve, que acontece o processo educativo do novo cidadão" (NOSELLA, 2010, p. 108), desvanecendo a ilusão da certeza do senso comum ${ }^{15}$, fundada na consciência ingênua ${ }^{16}$.

Corroborando a discussão, o cenário real não é um contexto fixo, tampouco, um universo físico, exigindo uma consciência política elevada, em virtude das coordenadas sociais e históricas que determinam sua configuração, interferindo nos espaços culturais, sociais e políticos (GOMÉZ, 1998, p. 59).

Anseia-se que, por meio da educação e formação política, os sujeitos sejam capazes de modificar a realidade através da compreensão do real ${ }^{17}$, tornando-se livres ${ }^{18}$ da lógica de ampliação da mais-valia ${ }^{19}$.

\footnotetext{
15 Produção e reprodução por meio da "[...] introjeção dos valores da ideologia dominante nas massas subalternas e integrado igualmente por reminiscências das concepções de mundo que prevaleceram em momentos de dominação já ultrapassados historicamente." (MOCHCOVITCH, 1990, p. 38).

16 Entende-se como sendo a visão superficial e acrítica da realidade concreta.

17 Por compreender ser mais amplo, adota-se o conceito de realidade defendido por Kosik (1976, p. 240, grifo do autor): "a realidade não é um sistema dos meus significados, nem se transforma em função dos significados que atribuo aos meus planos. Mas com o seu agir o homem inscreve significados no mundo e cria a estrutura significativa do próprio mundo."

18 Neste trabalho adota-se a concepção materialista de liberdade considerada como sendo o "espaço histórico que se desdobra e se realiza graças à atividade do corpo histórico, isto é, a classe. A liberdade não é um estado; é uma atividade histórica que cria formas correspondentes de convivência humana, isto é, de espaço social." (KOSIK, 1976, p. 241).

19 Frigotto (2008) descreve que "com efeito, no modo de produção capitalista, o trabalho daqueles desprovidos de propriedade de meios e instrumentos de produção é reduzido à sua dimensão de força-de-trabalho. Uma mercadoria especial que os proprietários dos meios e instrumentos de produção (capitalistas) compram e gerenciam de tal sorte
} 
Nesse diapasão, os conflitos, inerentes às relações entre as classes e frações de classes, tornam-se indispensáveis para selar um ritmo contínuo de reconstrução social pautado na fraternidade, solidariedade e cooperação, premissas libertárias da educação, que edifica à consciência política dos sujeitos, possibilitando que a sociedade civil organizada exerça a regulação e o controle social.

Para tanto, Goméz (1998, p. 62) diz que "é necessário provocar no aluno/a a consciência das insuficiências de seus esquemas habituais e o valor potencial de novos formas e instrumentos de análise da realidade plural."

Todavia, acredita-se que há uma expectativa de transformação diferente, que Fernandes $(1989$, p. 166) atribui existir em qualquer sociedade, a um processo político, onde a transformação "requer luta e luta social entre classes".

Por isso, entende-se que a tentativa de transformação desse contexto não deveria ser conduzida pelos conservadores $^{20}$ nem pelos reformistas ${ }^{21}$, e, sim, por meio dos revolucionários ${ }^{22}$.

Assim sendo, a escola não seria neutra, desde que seja projetada em uma "[...] esfera de ação propriamente política, em que no Brasil os educadores, mais até que os políticos são pessoas que convivem com os problemas essenciais da sociedade ao nível político" (FERNANDES, 1989, p. 167-168).

Nesse sentido, torna-se indispensável discutir o caráter educativo dos grupos organizados da sociedade civil (movimentos sociais) para com a formação política dos sujeitos, que se articulam dentro e/ou fora das escolas, já que por meio do compartilhamento das concepções e demandas populares, os indivíduos podem procurar contrapor-se à lógica de mercado ou reforçá-la, se assim desejarem.

Entende-se que isso ocorre porque se acredita que os seres humanos se constituem historicamente mediante seu agir prático coletivo, e assim, semeiam as pressões por transformações sociais, que podem originar um novo pensar e agir, uma revolução.

Convém destacar que os movimentos populares são reconhecidos como extensão da prática educativa (GOHN, 2012), podendo ser fomentado de dentro para fora ou de fora para dentro da escola, permitindo manter uma relação direta e constante entre a sociedade e as instituições escolares.

Compreender essa relação e a importância dos movimentos sociais (MS) é imperioso para reorganização da contra-hegemonia popular, tendo em vista a conjuntura em que se intensifica e mantém a estagnação político das classes subalternas.

Cumpre ressaltar que desde o Século XV quando os membros da classe operária não podiam ser membros do corpo político, já que a concepção hegemônica era que "a multidão, a plebe, não era considerada apta nem merecedora da participação política [...]” (ARROYO, 2010, p. 48), até a fase contemporânea, na primeira década do Século XXI, quando “o projeto burguês enfatizará a questão dos direitos dos indivíduos, menos como direitos e mais como deveres." (GOHN, 2012, p. 19), comprova-se que mesmo depois de vários séculos, ainda persiste um comportamento/cultura similar "para com os 'irracionais e desordeiros' assalariados" (ARROYO, 2010, p. 51, grifos do autor).

Para se contrapor a essa circunstância material, isto porque o processo de resistência é permeado por lutas constantes, apresenta-se na Figura 3 de forma sintética as fontes de autoconstrução do processo educativo e as consequências das práticas nos MS.

que o dispêndio da mesma pelo trabalhador, no processo produtivo, pague o seu valor de mercado (em forma de salário ou meios de subsistência) e, além disso, produza um valor excedente ou mais-valia que é apropriado pelo comprador." (FRIGOTTO, 2008, p. 403, grifo nosso).

20 Para Fernandes (1989, p. 167) é aquele que "[...] quer mudar alguma coisa, quer fazê-lo para preservar suas posições de poder ou, então, para amplificá-las, para não correr riscos.

${ }^{21}$ Denominado por Fernandes (1989, p. 167) como sendo aquele que “[...] quer mudar para conquistar posições de poder".

${ }^{22}$ Fernandes (1989, p. 167) compreende que seria aquele que "[...] quer mudar porque se identifica com classes que são portadoras de idéias novas a respeito da natureza, do conteúdo da civilização e da natureza do homem." 
Figura 1 - Quadro interações nos Movimentos Sociais

\begin{tabular}{|c|c|}
\hline 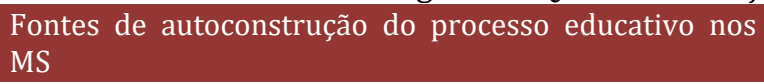 & \\
\hline $\begin{array}{l}\text { 1. Aprendizagem com a experiência de contato co } \\
\text { fontes de exercício do poder. }\end{array}$ & \multirow{5}{*}{$\begin{array}{l}\text { 1. Processo de politização dos participantes. } \\
\text { 2. Desenvolvimento da consciência individual e } \\
\text { coletiva. } \\
\text { 3. Desenvolvimento de práticas reivindicatórias que } \\
\text { servem como indicadores das demandas sociais e } \\
\text { reorientação das políticas públicas e dos governos. } \\
\text { 4. Manutenção da pressão e da resistência tendo como } \\
\text { efeito as alterações nas relações entre os agentes } \\
\text { envolvidos. } \\
\text { 5. Retroalimentação dos MS e da resistência das classes } \\
\text { subalternas. }\end{array}$} \\
\hline $\begin{array}{l}2 . \text { Ap } \\
\text { rotin }\end{array}$ & \\
\hline $\begin{array}{l}\text { 3. Aprendiza } \\
\text { social a pa } \\
\text { tratamentos }\end{array}$ & \\
\hline $\begin{array}{l}\mathrm{n} \text { as assessorias } \\
\text { nto. }\end{array}$ & \\
\hline $\begin{array}{l}\text { 5. Aprendizagem da d } \\
\text { como sinônimo de comp }\end{array}$ & \\
\hline
\end{tabular}

Fonte: Elaborado pelo autor (2016) adaptado de Gohn (2012).

Assim, depreende-se que essas fontes e formas de saber, no caso dos movimentos sociais, constituem-se como um instrumento imprescindível das classes populares, no sentido de contribuírem para atingir seus objetivos (GOHN, 2012), de contrapor-se ao modo de produção capitalista e na elaboração de condições materiais para tanto. Considerando o objeto desta pesquisa, formação política do estudante do Ensino Médio Integrado, discutir o papel dos movimentos sociais é fundamental, pois acredita-se que por meio dessa necessária ferramenta de resistência popular é que se faz oposição à alienação ${ }^{23}$ política imposta pelo capitalismo.

Marx (2010) critica de forma contundente, em sua Obra "Crítica a Filosofia do Direito de Hegel", a alienação política, dizendo que desconsiderar a família e a sociedade civil como esferas políticas, constituem uma espécie de alienação política, pois essa separação lógica, entre Estado e indivíduos, caso prospere, "impediria" concretamente a constituição dos sujeitos políticos, e, portanto, a partilha do Estado, conforme percebe-se na citação seguir:

A passagem da família e da sociedade civil ao Estado político consiste, portanto, em que o espírito dessas esferas, que é em si o espírito do Estado, se comporte agora, também, como tal em relação a si mesmo e que ele seja, quanto a sua interioridade, real em si. A passagem não é, portanto, derivada da essência particular da família etc. e da essência particular do Estado, mas relação universal entre necessidade e liberdade. [...] 0 desenvolvimento lógico da família e sociedade civil ao Estado é, portanto, pura aparência, pois não se desenvolve como a disposição familiar, a disposição social; a instituição da família e as instituições sociais como tais relacionam-se com a disposição política e com a constituição política e com elas coincidem (MARX, 2010, p. 32, grifo do autor).

Outro aspecto enfatizado por Marx (2010), na citação acima, é que a transformação dos indivíduos em entes políticos, descrita por ele como sendo "a passagem", não seria oriunda nem da família nem da sociedade civil, tampouco do Estado, mas compulsório e pretérito à liberdade, sendo necessário e motivador das ações revolucionárias.

Na citação, ainda percebe-se a convicção de Marx (2010) que a sociedade civil constituía a base real do Estado político, repercutindo ainda sobre a importância do reconhecimento dos fatos de risco social e políticoque cooperam para a formação da totalidade.

\section{CONSIDERAC̄̃̃ES FINAIS}

A revisão bibliográfica aponta que a educação política defendida pelo referencial crítico da filosofia da educação, seria o movimento estudantil ${ }^{24}$ como ator principal, assumindo o papel de um dos tentáculos

23 Gadotti (1997, p. 19) diz que a alienação se dá quando "um discurso que está em mim, me domina, fala por estranhos".

24 Percebem-se os grêmios como a materialização dos movimentos estudantis no âmbito da escola, que Ferretti, Tartuce e Zibas (2006) afirmam terem sido originados nos anos de 1960, tendo uma participação política bastante significativa, pois se confrontavam com os governos militares. Os mesmos autores ainda defendem que "naquelas circunstâncias, reunidos em uma grande organização nacional - a União dos Estudantes Secundaristas do Brasil -, e 
dos movimentos sociais, possibilitando, no âmbito escolar, o protagonismo dos estudantes, apontando na direção da liberdade consciente e sólida para ideação de uma sociedade emancipada, crítica e ciente do seu papel de controle social, de regulador do Estado.

De acordo com os expoentes estudados, percebemos que o saber popular politizado, condensado em práticas políticas participativas, torna-se uma ameaça às classes dominantes, à medida que são reivindicados espaços nos aparelhos do Estado que possuam caráter deliberativo. Esse saber coletivo é favorável à classe trabalhadora porque "[...] estaria invadindo o campo de construção da teia de dominação das redes de relações sociais e de vida social." (GOHN, 2012, p. 57).

Os estudantes revolucionados ${ }^{25}$ que podem emergir dessa formação política, devem:

[...] adequar sua ação às condições históricas, realizando o possível de hoje para que possam viabilizar amanhã o impossível de hoje. Uma de suas tarefas é descobrir os procedimentos mais eficientes, em cada circunstância, a fim de ajudar as classes dominadas a superar os níveis de consciência semiintransitiva e transitiva-ingênua pelo da consciência crítica, o que significa que se assumam como 'classe para si.' Esta preocupação não pode ser estranha a nenhum projeto revolucionário que é, também, ação cultural preparando-se para ser revolução cultura (FREIRE, 2015, p. 130-131).

A perspectiva advogada por Freire (2015) defende ideias congruentes da prática política consciente dos sujeitos, se relacionando à temporalidade, reflexão, intencionalidade e transcendência, aspectos nucleares da ação cultural ${ }^{26}$ para liberdade e da revolução cultural ${ }^{27}$ que o citado autor defende.

Diante do exposto, compreende-se neste estudo que através da formação de indivíduos autoconsciente do seu papel político, bem como, da consciência coletiva no sentido de acreditarem em si mesmo é possível vislumbrar uma educação que subsidie a transformação coletiva.

Assim, espera-se que através da oferta da educação profissional seja favorecido uma formação política ampliada aos indivíduos trabalhadores, capaz de cultivar homens e mulheres conscientes, livres e responsáveis, patrocinando o aperfeiçoamento humano para promover a ação direta sobre o curso dos processos sociais, interrompendo, assim, o círculo vicioso de alienação e subordinação posto pelo projeto hegemonico de sociedade.

\section{REFERÊNCIAS}

[1] Adorno, Theodor W. Educação e Emancipação. Rio de Janeiro: Paz e Terra, 1995.

[2] Arroyo, Miguel G. Educação e exclusão da cidadania. In: ARROYO, Miguel; BUFFA, Ester; Nosella, Paolo. Educação e Cidadania: quem educa o cidadão?. 14. ed. São Paulo: Cortez, 2010 (Coleção questões da nossa época; v. 16).

[3] Barroso, João. 0 reforço da autonomia das escolas e a flexibilização da gestão escolar em Portugal. In: Ferreira, Naura Syria Carapeto (Org.). Gestão democrática da educação: atuais tendências, novos desafios. 8. ed. São Paulo: Cortez, 2013.

[4] Bobbio, Norberto. O futuro da democracia. 9. ed. Tradução: Marco Aurélio Nogueira. São Paulo: Paz e Terra, 2000 .

[5] Bovero, M. Contra o governo dos piores: uma gramática da Democracia. Rio de Janeiro, Campus, 2002.

impossibilitados de levantarem as grandes bandeiras contra a ditadura, usavam qualquer pretexto para manifestações fora dos muros da instituição, desde reivindicação das mais particulares (por exemplo, destituição de um diretor autoritário), até as mais gerais (como protesto pelos baixos salários dos professores e o custo dos transportes). Com a democratização e a desmobilização dos movimentos sociais, inclusive com o enfraquecimento da organização nacional dos estudantes, o papel dessas entidades estudantis perdeu importância e hoje reconhece-se, em geral, que têm uma atuação frágil e descoordenada, apesar da atual ênfase na participação efetiva dos jovens na vida da escola e da comunidade. No entanto, mesmo nessa situação de fragilidade, é legítimo supor que os grêmios continuem a desempenhar papel considerável no jogo de poder que se desenvolve no campo institucional." (FERRETTI; TARTUCE; ZIBAS, 2006, p. 76-77).

25 Fazendo menção ao debate de Freire (2015) quanto ao papel dos sujeitos que assumem a condição de revolucionários na sociedade.

${ }^{26}$ A ação cultural para libertação "se realize em oposição às classes dominantes." (FREIRE, 2015, p. 138).

${ }^{27}$ A revolução cultural "se faz com a revolução já no poder." (FREIRE, 2015, p. 138). 
[6] Ferretti, Celso J.; Tartuce, Gisela Lobo B. P.; Zibas, Dagmar M. L. Micropolítica escolar e estratégias para o desenvolvimento do protagonismo juvenil. Cadernos de Pesquisa. v. 36, n. 127, p. 51-85, jan./abr. 2006.

[7] Fernades, Florestan. Desafio educacional. São Paulo: Cortez: Autores Associados, 1989 (Educação Contemporânea).

[8] França, Magna; Silva, Maria Aldeiza. Recursos financeiros: descentralização, gerenciamento e autonomia na perspectiva dos diretores escolares. In: Castro, Alda Maria Duarte Araújo; Barbalho, Maria Goretti Cabral (Orgs.). Formação de gestores a distância: uma contribuição para gestão democrática da escola. Natal - RN: Edufrn, 2012.

[9] Freire, Paulo. Pedagogia da autonomia: saberes necessários à prática educativa. São Paulo: Paz e Terra, 2011.

[10] _ _ Paulo. Ação cultural para a liberdade e outros escritos. 15.ed. Rio de Janeiro: Paz e Terra, 2015.

[11] Frigotto, Gaudêncio; Trabalho. In: Pereira, Isabel Brasil; Lima, Júlio César França. Dicionário da educação profissional em saúde. 2. ed. rev. ampl. - Rio de Janeiro: Epsjv, 2008. p. 399-404.

[12] Gadotti, Moacir. Escola Cidadã. 4. ed. São Paulo: Cortez, 1997 (Coleção questões da nossa época; v. 24).

[13] _ _ Moacir. Concepção Dialética da Educação: um estudo introdutório. 16. ed. São Paulo: Cortez, 2012.

[14] Gohn, Maria da Glória. Movimentos sociais e educação. 8. Ed. São Paulo: Cortez, 2012 (Coleção questões da nossa época; v. 37).

[15] Goméz, A. I. Peréz. A aprendizagem escolar: da didática operatória à reconstrução da cultura na sala de aula. In: Sacristán, J. Gimeno; Goméz, A. I. Peréz. Compreender e transformar o ensino. Tradução Ernani F. da Fonseca Rosa. 4. ed. Artmed, 1998.

[16] Kosik, Karel. Dialética do Concreto. Traducao de Célia Neves e Alderico Toríbio. 2. ed. Rio de Janeiro: Paz e Terra, 1976.

[17] Manacorda, Mario Alighiero. Marx e a pedagogia moderna. Campinas, São Paulo: Editora Alínea, 2007.

[18] Marx, Karl. Crítica da filosofia do direito de Hegel: 1843. 2. ed. rev. São Paulo: Boitempo, 2010. 175 p.

[19] Mészáros, István. A educação para além do capital. Tradução Isa Tavares. 2. ed. São Paulo: Boitempo, 2008 (Mundo do Trabalho).

[20] Mochcovitch, Luana Galano. Gramsci e a escola. 2. ed. São Paulo: Átilas, 1990.

[21] Montaigne, Mochael de. Os ensaios: livro I. 2. ed. São Paulo: Martins Fontes, 2002.

[22] Moura, Dante Henrique. Mudanças na sociedade brasileira dos anos 2000 limites pela hegemonia do neoliberalismo: implicações para o trabalho e para a educação. In: Moura, Dante Henrique (Org). Produção do conhecimento, políticas públicas e formação docente em educação profissional. Campinas, SP: Mercado de Letras, 2013. - (Série Educação Geral, Educação Superior e Formação Continuada do Educador).

[23] Nosella, Paolo. Educação e cidadania em Antonio Gramsci. In: Arroyo, Miguel; Buffa, Ester; Nosella, Paolo. Educação e Cidadania: quem educa o cidadão?. 14. ed. São Paulo: Cortez, 2010 (Coleção questões da nossa época; v. 16).

[24] Oliveira, Dalila Andrade. A gestão democrática da educação no contexto das reformas do Estado. In: Ferreira, Naura Syria Carapeto; Aguiar, Márcia Angela da S (Orgs.). Gestão da educação: impasses, perspectivas e compromissos. 5. ed. São Paulo: Cortez, 2006.

[25] Paro, Vitor Henrique. Crítica da estrutura da escola. São Paulo: Cortez, 2011.

[26] Petras, James. O manifesto comunista: qual sua relevância hoje?. In: Marx, Karl. Engels, Friedrich. Manifesto Comunista. Organização e Introdução Osvaldo Coggiola. 1. ed. Revista. São Paulo: Boitempo, 2010.

[27] Poulantzas, Nico. O Estado, o poder, o socialismo. Rio de Janeiro: Graal, 2000.

[28] Santos, Boaventura de Sousa (Org.). Democratizar a democracia: os caminhos da democracia participativa. Rio de Janeiro: Editora Civilização Brasileira, 2002a (Reinventar a emancipação social: para novos manifestos).

[29] _ _ Reinventar a Democracia. 2. ed. Lisboa: Fundação Mário Soares Gradiva Publicações, 2002b.

[30] Wood, Ellen Meiksins. Democracia contra capitalismo: a renovação do materialismo histórico. Tradução Paulo Cezar Castanheira. São Paulo: Boimtempo, 2011. 


\section{Capítulo 10}

Modelos de gestão e coordenação de cursos de graduação: Um estudo comparativo em universidade pública e privada28

José Euzébio de Oliveira Souza Aragão

Paulo Antonio da Graça Lima Zuccolotto

Maria Aparecida Bovério

Vanessa Terra Pereira

Resumo: A figura do coordenador de curso existe desde a década de 1960 no ensino superior brasileiro, mas foi somente a partir da lei n. 9.394/96 que o coordenador de curso assumiu um papel fundamental na gestão dos cursos de graduação. Outro fator que ressignificou o papel do coordenador foi a implantação das políticas públicas de avaliação do ensino superior, em meados da década de 1990, e as transformações que levaram a uma diversificação e diferenciação da educação superior no Brasil, configurando a reestruturação com viés neoliberal. A partir de pesquisa bibliográfica, análise documental e observação participante, discute-se o papel, o perfil e os desafios do coordenador de curso como gestor acadêmico, identificando modelos de gestão em uma universidade pública e em uma universidade privada.

Palavras-chave: coordenador de curso; gestão de curso de graduação; modelos de gestão.

28 Publicado inicialmente na REGAE - Revista de Gestão e Avaliação Educacional, com o título "Desafios do coordenador na gestão de cursos de graduação: um estudo comparativo em universidade pública e privada", volume 8 , no $17,2019$. 


\section{INTRODUÇÃO}

A figura do coordenador de cursos de graduação já existe desde a década de 1960 no ensino superior brasileiro, mas foi somente a partir da Lei de Diretrizes e Bases da Educação Nacional no 9.394/96 que o coordenador de curso assumiu um papel fundamental na gestão dos cursos de graduação das instituições de ensino superior brasileiras. Além da referida lei, outro fator que ressignificou o papel do coordenador de cursos foi a implantação das políticas públicas de avaliação do ensino superior, a partir de meados da década de 1990.

Mais do que implantação de políticas públicas de avaliação do ensino superior, desde a década de 1990, esse nível de ensino passou por transformações que incluem o Programa Universidade para Todos, o Programa de Apoio a Planos de Reestruturação e Expansão das Universidades Federais, a oferta de cursos superiores a distância, as políticas de ações afirmativas e, em geral, uma diversificação e diferenciação da educação superior no Brasil: uma reestruturação da educação superior no Brasil que inclui, especialmente, um novo padrão de modernização e gerenciamento para o campo universitário.

Esse modelo de gestor e de gestão vai buscar na Teoria Geral de Administração os seus fundamentos. 0 pressuposto dessa concepção de administração educacional é o de que administrar uma escola é equivalente à administração de uma empresa. De fato, quando nos referimos a gestão, estamos falando de uma atividade, ou de uma série de atividades integradas, destinadas a permitir que certa combinação de meios possa gerar uma produção de bens ou serviços, mas cabe à administração escolar criar condições que favoreçam o processo educativo escolar e os resultados são consequências da conjugação de inúmeros fatores. A eficácia e eficiência do processo escolar acontece a partir da mediação entre os recursos e os resultados alcançados, mas no caso da escola, a administração é orientada pelo projeto políticopedagógico.

Neste texto discute-se o papel, o perfil e os desafios do coordenador de curso como gestor acadêmico, identificando modelos de gestão em uma universidade pública e em uma universidade privada. Utilizamos pesquisa bibliográfica, análise documental e observação participante para atingir nossos objetivos. Dentre os documentos analisamos estatutos, regimentos, portarias, resoluções normativas e normas das instituições pesquisadas. Três dos quatros autores deste trabalho têm experiência de mais de uma década em gestão de cursos e instituições, sendo que dois deles atuam, atualmente, nas instituições pesquisadas.

\section{OS MODELOS DE GESTÃO: REVISITANDO AS TEORIAS DE ADMINISTRAÇÃO EM BUSCA DE UMA TEORIA DA ADMINISTRAÇÃO ESCOLAR}

Tanto a palavra administração, quanto gestão são de origem latina, gerere e administrare. Gerere significa conduzir, dirigir, governar. Administrare tem aplicação específica no sentido de gerir um bem, defendendo os interesses dos que o possuem (Ferreira; Reis; Pereira, 1997).

Para Aktouf (1996), termos como gestão, administração, ou gerir, administrar, ou ainda gestor, administrador, gerente, dirigente criam mais confusões do que ajudam. 0 autor prefere considerar esses termos como sinônimos. Motta (1999) concorda com Aktouf (1996) quando afirma não ver grandes dissociações entre os termos executivo, gerente ou administrador. Todos trabalham essencialmente nas decisões e, mais que seus superiores, estabelecem sentidos de direção para suas empresas e instituições.

No Brasil as palavras administrador e gerente designam qualquer posição de direção e chefia. 0 termo administração, desgastado por sua prática equivocada, perdeu sua imponência pela palavra gerência. Até a década de 1970, no Brasil, a palavra administrador, apesar de pouco usada, tinha a sua importância mais acentuada do que a de gerente. Dirigentes de alto nível eram preferencialmente administradores. Gerentes eram considerados os de hierarquia mais baixa ou os que exerciam funções em pequenos comércios. 0 desgaste da palavra administração revigorou a expressão gerência, que passou a designar funções executivas de grandes empresas (Motta, 1999).

Na década de 1990 o termo gestão ganhou espaço, acrescentando algumas novidades, sem, entretanto, significar uma mudança conceitual. Para Motta (1999), o termo gestão ganhou espaço por sua generalidade e pureza modernas, ainda não desgastado por uso e desusos e exemplo dos termos administração e gerência. 
Na verdade, quando estamos falando de gestão, ou administração, ou gerência,

estamos falando de uma atividade, ou mais precisamente, de uma série de atividades integradas e interdependentes, destinadas a permitir que certa combinação de meios (financeiros, humanos, materiais etc.) possam gerar uma produção de bens ou serviços economicamente e socialmente úteis e, se possível para a empresa, com a finalidade lucrativa, rentáveis. (Aktouf, 1996, p. 25)

Essa atividade, ou série de atividades integradas e interdependentes, foi sistematizada e definida a partir de princípios e funções por Taylor e Fayol desde o início do século 20 e daí até os dias atuais surgiram contribuições das mais variadas tentando transformar a administração em uma ciência, ou seja, embasada em princípios científicos, muito distantes do senso comum na condução das organizações, configurando modelos de gestão.

Quando se fala em gestão é imperativo entender que os ambientes organizacionais são únicos, tanto internamente, como recursos, estrutura, etc. quanto externamente, como grau de competitividade ou público a ser atendido. Portanto desta compreensão nasce a estratégia gerencial para se atingir os objetivos. Conhecer, portanto, os ambientes organizacionais interno como externo, é condição fundamental para indicar modelos adequados para a organização administrada.

Em gestão, quando se refere a modelo segundo Robbins (1978) citado por Pereira e Santos (2001) se induz a uma representação simplificada do ambiente que ajuda na compreensão das relações complexas do mundo organizacional. Objetivamente os modelos podem substituir complexidade por simplicidade: "Assim, tratando-se de uma descrição abrangente, que procure refletir toda a realidade organizacional, espera-se que todos os elementos básicos constituintes de uma organização qualquer - tarefas, estruturas, pessoas e tecnologias sejam contemplados" (PEREIRA; SANTOS, 2001, p. 39).

Para Maximiano (2012) os modelos de gestão, normalmente, estão associados ao ambiente de competitividade a que a organização está exposta. Segundo o autor ambientes competitivos mais intensos requerem modelos orgânicos de gestão cujas características estão em estruturas mais flexíveis, menos burocratizadas, participativas, entretanto menos especializadas. Organizações mecanísticas ou mecanicistas estão associadas a ambientes mais estáveis cuja necessidade de especialização é maior, uma vez que o grau de competitividade é determinado por estabilidade e profundidade na relação com o mercado.

Antes de definirmos os tipos de gestão na concepção de Aktouf (1996), recorreremos as reflexões de Abreu (1982) sobre a evolução da teoria administrativa. Abreu (1982) distingue quatro momentos cruciais no desenvolvimento da teoria organizacional. 0 primeiro momento corresponde ao grupo de engenheiros americanos Taylor, Gilbreth e

Gilbreth, denominado de grupo mecanicista, "cuja concepção se resumia, basicamente, no estudo da organização vista de baixo para cima ou, melhor dizendo, ao nível operacional dos trabalhadores manuais" (Abreu, 1982, p. 41). Ainda a esse primeiro momento soma-se as ideias de Fayol - e Urwick, Gulick, etc. -, também engenheiro, mas francês, "que toma como referência um patamar mais alto da organização, ou seja, a análise do papel do dirigente e, também da própria estrutura organizacional da empresa" (Abreu, 1982, p. 41), sendo por isso chamado de grupo anatômico.

À fusão das ideias desses dois grupos atribui-se o nome de Escola Clássica, que tem como preocupações fundamentais a definição de um modelo de organização do trabalho - no chão de fábrica e na cúpula- que busca a eficiência e produtividade por meio de princípios que visam substituir o empirismo.

O segundo momento origina-se nas experiências de Elton Mayo e Fritz

Roethlisberger, realizadas entre 1927 e 1932 na Western Eletric Company, em Hawthorne, Chicago. Partindo de premissas da Escola Clássica, Mayo e Roethlisberger descobriram a importância do elemento humano e sua complexidade para o desempenho organizacional. Um desdobramento da chamada Escola das Relações Humanas, os comportamentalistas ampliaram os estudos do primeiro, chamando a atenção às questões de motivação, participação, democratização do ambiente de trabalho, trabalho em grupo e outros aspectos correlatos.

0 terceiro momento da evolução da teoria organizacional lança mão do conceito advindo da biologia - o de sistemas - para analisar as organizações. Essa vertente vê as organizações como sistemas abertos, que interagem com o ambiente em que atuam, recebendo insumos e exportando produtos ou serviços. Por outro lado, as organizações são compostas por subsistemas internos, com interação dinâmica uns com os 
outros e, portanto, mutuamente dependentes. Essa compreensão da organização traz à tona o fato de que as organizações só poderão sobreviver em um ambiente de alta mutabilidade na medida em que desenvolvam mecanismos de adaptação contínua ao meio ambiente.

O último momento segundo Abreu (1982), é chamado de enfoque contingencial e dá sequência às ideias do enfoque sistêmico explicitado anteriormente. 0 enfoque contingencial preconiza que não há princípios ou critérios universais para se administrar as organizações. 0 desenho organizacional deve corresponder ao ajustamento entre a empresa e o seu ambiente.

Essa perspectiva, Teoria das Contingências, entende que situações diferentes exigem práticas diferentes podendo utilizar as teorias tradicionais clássicas, comportamentais e de sistemas separadamente ou de maneira combinada na busca de soluções para as organizações (SILVA, 2001).

Do modelo mecanicista/anatômico ao modelo contingencial, passando pelos modelos das relações humanas/comportamental e sistêmico vemos o incremento de novas perspectivas acerca das organizações. Contudo, parece prevalecer uma ideia de ecletismo entre os diversos enfoques, na medida em que uma concepção não inviabiliza as outras, permitindo-se e admitindo-se a aplicação de vários enfoques em uma mesma organização, salvo alguns aspectos conflitantes. 0 que queremos enfatizar é que as ideias de Taylor e Fayol, ao ressaltarem os aspectos da organização do trabalho e da eficiência em primeiro plano, não menosprezam o papel do elemento humano, apenas o considera secundário diante do contexto social, econômico e político. Ao mesmo tempo, os pressupostos da Escola das Relações Humanas e dos Comportamentalistas não se afiguram como opositores aos anseios de produtividade da Escola Clássica. E nem mesmo o fazem os sistêmicos, de maneira que podemos inferir que não há embates ideológicos no campo da administração. De certa forma, as teorias se complementam e o conhecimento a respeito das organizações se acumula, elaborando o ecletismo citado anteriormente.

De maneira geral diríamos que a Escola Clássica, acrescida do modelo burocrático - não tratado nos quatro momentos do desenvolvimento da teoria organizacional - delineiam um modelo de gestão chamado de tradicional, resultado de aspirações e experiências que foram se consolidando e atingiram seu apogeu nas ideias de Taylor Fayol. 0 modelo burocrático remete a algumas características, a partir dos tipos ideais de organizações, de Max Weber. Podemos destacar algumas dessas características como centralização das decisões, regulamentação pormenorizada, previsibilidade, formalismo, impessoalidade e obsessão por documentos escritos. Essas características apresentam a organização burocrática como um modelo organizacional assentada no princípio da racionalidade, que se traduz na previsibilidade, na consensualidade sobre os objetivos, na adequação dos meios aos fins, nos processos de decisão e planejamento estáveis.

A gestão tradicional pode ser comparada ao exército e a máquina, e a colmeia e o formigueiro. Simboliza a previsibilidade, a disciplina, a ordem, a lógica mecânica, a especialização de funções, a conduta racional, mas também uma concepção do ser humano e de relações de trabalho carregadas de aspectos negativos para o desempenho e produtividade (AKTOUF, 1996). Embora fortemente alicerçada nas ideias da escola Clássica, a gestão tradicional inclui também as correntes da Psicologia e da Sociologia Industrial que "acrescenta a crença na possibilidade de manipular e de modificar as percepções, as convicções e as atitudes dos indivíduos para canalizá-las no sentido desejado pelos dirigentes" (AKTOUF, 1996, p. 32). Para esse autor, a gestão tradicional engloba o conjunto de teorias administrativas anteriores às correntes da cultura organizacional e da qualidade total.

A gestão renovada ou inovadora, por outro lado, típica de organizações modernas, resolve os problemas organizacionais utilizando criatividade e inovação. Aktouf (1996) enfatiza que o estilo de gestão inovador/renovado tem como fundamento um novo modo de relação entre dirigentes e dirigidos, empregadores e empregados e, sobretudo, entre empregados e empresas. Para o autor apenas poucas organizações no mundo têm efetivamente caminhado para uma real renovação de sua gestão. Na verdade, o que impera, é o modelo tradicional, taylorista, burocrático e conservador, acrescido de alguns aspectos modernizantes.

A gestão inovadora mexe com a questão do poder nas organizações, com as relações de trabalho e com o processo milenar de conceber e executar, mas de forma coletiva e democrática. Essa gestão inovadora requer mudança da cultura organizacional, trabalho em equipe, autonomia das equipes quanto a objetivos e desempenhos, diminuição dos níveos hierárquicos e pela reaproximação das relações entre as funções da empresa, de forma integrada.

Segundo Russo (2004), "no Brasil, a administração educacional tem se pautado, teórica e praticamente, no paradigma da administração empresarial que encontra na Teoria Geral da Administração a expressão do 
seu pensamento e a formulação de suas práticas" (p. 27). 0 pressuposto dessa concepção de administração educacional é o de que administrar uma escola é equivalente à administrar uma empresa. Outros argumentos são: a administração é uma técnica, ou seja, conjunto de princípios e métodos que asseguram melhores resultados; é universal, já que se aplica a qualquer tipo de organização, a qualquer situação e contexto e, por último, é neutra, pois foi construída de modo desinteressado e à parte dos conflitos que se manifestam nas organizações (RUSSO, 2004).

O autor contesta tais argumentos, considerando a Teoria Geral da Administração um instrumento de dominação do capital sobre o trabalho para conseguir um crescente aumento da eficácia e eficiência do trabalho, ou de sua produtividade. Não se registram, portanto, nas teorias da Administração, estudos que reflitam os interesses dos trabalhadores e adotem uma perspectiva da democratização do poder nas organizações como apregoa a gestão inovadora/renovada.

As propostas de superação do paradigma da administração empresarial como fundamento da administração escolar, segundo Russo (2004), têm por hipótese a natureza específica do processo pedagógico de produção escolar, que

significa produzir um conhecimento sobre o trabalho pedagógico escolar e sua organização, voltado a melhorar qualitativa e quantitativamente a formação de sujeitos da educação, isto é, que seja um conhecimento iluminador da prática e indicador dos caminhos que a transformam em verdadeira práxis criadora e reflexiva; que venha oferecer contribuições para o aumento da produtividade da aprendizagem dos alunos e produza efeitos contrários aos da burocracia que, enquanto forma de estruturação das organizações, é uma maneira específica de exercício do poder que favorece o autoritarismo e dificulta a participação e a democratização das organizações. (Russo, 2004, p. 30)

À administração escolar cabe criar condições que favoreçam o processo educativo escolar e os resultados são consequências da conjugação de inúmeros fatores (RUSSO, 2004). 0 foco são os resultados tendo por base o projeto político-pedagógico e não a ideia de lucro.

Goldbarg (1998), apontando dificuldades de aplicação dos sistemas de qualidade total na área de educação, contribui para a necessidade de construção de uma teoria da administração escolar desvinculada da Teoria Geral da Administração. Para esse autor, o sistema escolar possui uma estrutura e um relacionamento entre os subsistemas significativamente diferentes do sistema industrial:

Em nenhuma atividade produtiva, o aspecto afetivo é tão significativo quanto o é na educação. A dimensão afetiva tem um papel enorme no despertar do potencial dos alunos e professores e, em consequência, na qualidade do ensino. Os laços que podem unir mestres e alunos vão além daqueles que ligam um produtor ao seu cliente mais simpático. Um mestre não dá aula, mas influencia na formação de uma pessoa. A peculiaridade das relações professor x aluno exigirá, sem qualquer sombra de dúvida, uma adaptação no conceito de cliente. (GOLDBARG, 1998, p. 57)

Um segundo aspecto é a interdisciplinaridade: "Uma escola é uma organização que possui processos extraordinariamente interdependentes, mas, mesmo assim, deve preservar a iniciativa, a criatividade e a independência intelectual de todos os seus componentes. A interdisciplinaridade é um desafio para a padronização" (GOLDBARG, 1998, p. 57).

Por último, o aspecto da importância do compromisso social. Toda empresa tem um compromisso com a sociedade, variando o grau de acordo com a atividade praticada, mas, segundo o autor:

0 caso da educação é diametralmente oposto. É ela exatamente a parte do tecido social que recebe uma das amplas e contínuas delegações de influenciar o futuro da própria sociedade. Não importando se pública ou particular, em virtude de seu papel delegado, toda escola tem um forte dever com o social, compromisso esse que engloba a obrigação com um serviço de excelência e extensivo ao maior número de pessoas. Absolutamente nenhuma escola, em nenhum nível, em nenhum lugar da Terra pode ser encarada com um simples negócio. Essa mentalidade simplesmente desqualifica a organização para exercer a delegação de educar. Moldar o cidadão não pode ser encarado apenas como um negócio como outro qualquer. Pensando assim, estaríamos reduzindo os seres humanos no nível das coisas barganháveis e quantificáveis 
fiduciariamente. [...] Negociar a educação é um dos mais lamentáveis e grosseiros erros que um administrador pode cometer. A escola só poderá alcançar a qualidade com uma dose de dedicação e compromisso que transcende o foco no resultado financeiro. (GOLDBARG, 1998, p. 58)

Além desses aspectos, frisa Goldbarg (1998, p. 54):

a) o contexto educacional é mais sofisticado e complexo;

b) os impactos sociais da atividade produtiva educacional são um dos mais importantes aspectos do fenômeno;

c) os clientes possuem necessidades e expectativas extremamente sofisticadas e conflitantes;

d) os ciclos de vida são contados dentro de outras escalas;

e) existe outro nível de envolvimento emocional em jogo: o do crescimento da alma humana e não somente de sua satisfação dimensional. (Goldbarg, 1998, p. 54)

Portanto, se gerir recursos nas organizações é uma tarefa complexa em função das características e das finalidades da administrada, a gestão da instituição escolar adota dimensões de maior complexidade uma vez que a tangibilidade dos resultados não deve ou não pode medidas no curto prazo como um fato meramente econômico ou a eficiência na utilização dos recursos. Os resultados de uma instituição escolar serão medidos ao longo de um percurso que tangibilizará o nível de eficácia alcançada tendo como referência seu objetivo e posicionamento.

\section{COORDENAÇÃO DE CURSOS DE GRADUAÇÃO: EXIGÊNCIA LEGAL OU NECESSIDADE DE GESTÃO?}

A figura do coordenador de cursos de graduação já exista desde a década de 1960 no ensino superior brasileiro, mas foi somente a partir da Lei de Diretrizes e Bases da Educação Nacional no 9.394/96 que o coordenador de curso assumiu um papel fundamental na gestão dos cursos de graduação das instituições de ensino superior brasileiras. 0 curso tomou a forma de uma unidade acadêmico-administrativa dentro das instituições e seu coordenador passa a ser visto como gestor dessa unidade.

A importância do coordenador de curso no cenário da educação superior no Brasil se deve, em grande parte, a não exigência de departamentos no âmbito das instituições de ensino superior. A maioria das instituições extinguiu-os de suas estruturas organizacionais, preferindo acolher a ideia de coordenação de curso e atribuindo ao novo setor a responsabilidade pela direção e pelo sucesso dos cursos superiores (FRANCO, 2002).

Além da referida lei, outro fator que ressignificou o papel do coordenador de cursos foi a implantação das políticas públicas de avaliação do ensino superior a partir de meados da década de 1990. A experiência brasileira de avaliação educacional não é recente, já havia experiências na pós-graduação desde a década de 1970 e outras iniciativas durante a década de 1980, mas foi somente a partir de 1995, com a lei n. 9.131, que o governo federal definiu uma sistemática de avaliação coordenada pelo MEC.

A partir de então implantou-se avaliações periódicas das instituições e cursos de graduação, utilizando-se procedimentos e critérios abrangentes e complexos:

Essa política de avaliação do ensino superior, desenvolvida ao longo dos dois mandatos do Presidente Fernando Henrique Cardoso (de 1995 a 1998 e de 1999 a 2002) causou polêmica em toda a comunidade acadêmica e teve os holofotes voltados, principalmente, para o ENC, que possibilitava a divulgação, pela primeira vez, de um ranking dos cursos de graduação no Brasil. (ARAGÃo; FRANÇA; ZUCCOLOTTO, 2016, p.148)

Mais do que implantação de políticas públicas de avaliação do ensino superior, desde a década de 1990 esse nível de ensino passou por transformações que incluem o Programa Universidade para Todos, o Programa de Apoio a Planos de Reestruturação e Expansão das Universidades Federais, a oferta de cursos superiores a distância, as políticas de ações afirmativas e, em geral, uma diversificação e diferenciação da educação superior no Brasil. De fato, essas políticas "configuram a existência de uma reestruturação da educação superior no Brasil, que inclui, especialmente, um „novo "padrão de modernização e gerenciamento para o campo universitário, inclusos no novo paradigma de produção capitalista e na reforma da administração pública do Estado" (CATANI; OLIVEIRA, 2000, p. 63). 
Nesse cenário de reestruturação produtiva e de reforma da administração pública do Estado, ganharam força as teses neoliberais ou neoconservadoras que identificam a crise como sendo de responsabilidade do Estado, particularmente do Estado de bem-estar social, que as políticas de cunho social o levaram a uma crise fiscal.

Essa reestruturação afetou a educação: em dez anos as matrículas em cursos superiores, presenciais e a distância, mais que dobraram: de 3.036.113, em 2001, passaram para 6.379.299 em 2010. Apesar do total de matrículas - federais, estaduais, municipais e privadas - ter alcançado um crescimento de $110 \%$ nesse período, o fato é que a rede privada continua sendo a grande responsável pelo ensino superior no país.

É nesse contexto que se insere uma discussão sobre a gestão de cursos de graduação. A figura do coordenador de curso deixou de ser simbólica e se tornou um imperativo para o sucesso dos cursos de graduação. A denominação de gestor é atualmente a mais adequada por abranger as diversas nomenclaturas encontradas para os dirigentes de cursos. 0 gestor do curso, principalmente os de IES privadas, envolve-se nas questões pedagógicas, nas questões administrativas, de infraestrutura, tendo como eixo o projeto pedagógico do curso:

Tanto no passado como no presente, ainda não se chegou a um denominador comum quanto às funções, às responsabilidades, às atribuições e aos encargos do Coordenador de Curso. Diz-se ser ele o gerente do Curso. Chega-se mesmo a afirmar que é o dono do Curso. Na realidade, predominam na figura do Coordenador de Curso e, de certa forma na concepção geral, apenas os encargos acadêmicos. São relegadas por ele as responsabilidades não acadêmicas, ou seja, as responsabilidades e funções gerenciais, políticas e institucionais, no estrito sentido dessas expressões. (FRANCO, 2002, p. 3)

De fato, qualquer pesquisa bibliográfica sobre gestão de cursos de graduação vai resultar em poucas referências e, em geral, a artigos científicos empíricos que visam ou definir as atribuições e responsabilidades do gestor de cursos, ou descrever as atribuições em instituições de ensino superior, na maioria das vezes revelando suas próprias experiências e em busca de um gestor ideal.

Nesse sentido, Franco (2002) descreve as funções necessárias para atuação de um coordenador de curso ideal. São elas: funções políticas, gerenciais, acadêmicas e institucionais. envolvem liderança; ser um animador proativo; ser o representante de seu curso; ser o fazedor do marketing do curso; ser responsável pela vinculação do curso com os anseios e desejos do mercado; ser o responsável pela supervisão das instalações físicas; laboratórios e equipamentos do curso; ser o responsável pela indicação da aquisição de livros; materiais especiais e assinatura de periódicos necessários ao desenvolvimento do curso; ser responsável pelo estímulo e controle da frequência docente; pela indicação da contratação de docentes e, logicamente, pela indicação da demissão deles; ser o responsável pela elaboração e execução do projeto pedagógico do curso; ser responsável pela qualidade e pela regularidade das avaliações desenvolvidas em seu curso; estimular a iniciação científica e de pesquisa entre professores e alunos; ser responsável pelo sucesso dos alunos de seu curso nas avaliações em larga escala do MEC; ser responsável pelo acompanhamento dos antigos alunos do curso, dentre outras atribuições.

Essas quatro funções, segundo Jacobucci e Jacobucci (2008), mitificam o profissional que assume o cargo de coordenador e influenciam os administradores universitários a exigir uma sobre carga de trabalho dos coordenadores pela jornada de 40 horas semanais. Embora pareça uma missão impossível, essas funções são exigidas por muitas instituições particulares de ensino superior, sem que a contrapartida, a remuneração chegue próxima aos valores pagos aos executivos de grandes empresas.

Percebe-se, então, a necessidade de envolvimento em variadas funções que vão além dos saberes construídos em sua formação e exercício da docência, respondendo tanto pedagógica, política, quanto administrativamente pelo curso que coordena. Dessa forma, coordenar um curso exige um envolvimento em questões políticas, gerenciais, acadêmicas e institucionais que remetem a uma contrapartida para com a sociedade, docentes, salas de aula, instituição e atores, apontando para uma amplitude de saberes necessários para o exercício da função (NOGUEZ; TILLMANN; DUARTE, 2016).

Outro aspecto importante de ressaltar é que na maioria das vezes o gestor do curso tem como parâmetros de gestão o que se preconiza nas avaliações institucionais. Normalmente esses parâmetros são lidos como um caderno de normas o que invariavelmente tem como objetivo do cumprimento de dispositivos legais sem que, no entanto, estejam orientados por um modelo de gestão concebido pela instituição. 0 modelo de gestão deverá ter como consequência o entendimento sobre a perpetuação da instituição de ensino além, é claro, o de atender os dispositivos legais e seus critérios de avaliação. 
Os atuais mecanismos e instrumentos de avaliação externa a que os cursos de graduação estão expostos não se resumem ao ENADE. Além do governo que exerce uma função reguladora oficial da Educação Superior, o mercado produziu ao longo dos últimos anos ferramentas destinadas a aferir a qualidade de cursos em Instituições de Ensino Superior, traduzidos em rankings. O que importa é que o coordenador de curso deve se apropriar das políticas de avaliação e que dentre suas tantas atribuições, desenvolva ações que impactem nos resultados das avaliações (ARAGÃO; FRANÇA; ZUCCOLOTTO, 2016, p. 158)

\section{AS INSTITUIÇÕES PESQUISADAS: CARACTERIZAÇÃO, ESTRUTURA E GESTÃO DE CURSO}

As duas universidades, objeto deste trabalho, estão localizadas no interior do Estado de São Paulo. A primeira IES pesquisada é uma instituição privada, comunitária, confessional e filantrópica, criada em 1941. Iniciou com a Faculdade de Filosofia, Ciências e Letras e a Faculdade de Ciências Econômicas oferecendo, à época, oito cursos. Em 1955 tornou-se universidade, com aprovação do então Conselho Federal de Educação. Possui cerca de 16.000 alunos na graduação, alocados em dois campi na mesma cidade, com cursos nas diversas áreas, além dos alunos em pós-graduação - lato e stricto sensu - e de extensão. Atualmente oferece 61 cursos de graduação, nove cursos de mestrado e três de doutorado, além de 21 opções de pós-graduação lato sensu.

O coordenador de curso, que nesta IES recebe a denominação de Diretor de Faculdade. Cada Faculdade pode oferecer mais de um curso e, portanto, neste caso, diretores adjuntos são nomeados para a coordenação de curso. A direção de Faculdade se situa no quarto nível hierárquico da instituição, subordinado a uma Direção de Centro. Os centros são unidades organizacionais básicas que se constituem por faculdade e estas por cursos. Além das faculdades, cada centro possui um Núcleo de Pesquisa e Extensão, que coordena essas atividades no nível do Centro. Atualmente a IES possui cinco centros: Centro de Ciências Exatas, Centro de Ciências da Saúde, Centro de Ciências Humanas e Sociais, Centro de Ciências Econômicas e Administrativas e Centro de Comunicação e Linguagem.

O ensino da graduação é feito por cursos com supervisão próxima de Conselho de Faculdade formado por professores do próprio curso, eleitos entre seus pares, além de representante do corpo discente e dos diretores ou diretores adjuntos de Faculdade. Os diretores ou diretores adjuntos de Faculdades são as instâncias executivas de coordenação de ensino de cada curso.

Até 1998 a escolha para coordenador do curso era por eleição direta; a última foi em 1996 . 0 corpo docente, discente e corpo técnico escolhiam e mandavam uma lista para a reitoria, que decidia. Em 1998 a mantenedora assumiu a direção da instituição e passou a indicar o reitor e as duas vice-reitorias, que escolhem os gestores das faculdades. As atribuições dos gestores são regimentais. Há um conselho de curso de cada faculdade com representação de professores, alunos e funcionários. 0 conselho é que define as diretrizes do curso, discute o projeto, contrata e demite docentes, gerencia conflitos. 0 presidente do Conselho é o diretor da Faculdade. 0 conselho tem autonomia estabelecida em regimento, ele dá pareceres e é a instância de suporte à decisão.

O Diretor de Faculdade tem diversas atribuições regimentais que envolvem questões como convocar e presidir o Conselho de Faculdade, coordenar a elaboração, a implantação, o desenvolvimento, a avaliação e o aperfeiçoamento do projeto pedagógico do curso, constituir comissões internas, planejar e apresentar à diretoria de Centro a proposta de infraestrutura necessária ao adequado funcionamento do curso, informar, aconselhar e orientar os alunos quanto ao funcionamento da universidade, processo de matrícula, regime escolar, currículos, estágios, iniciação científica, monitoria e outras informações relevantes, assessorar, supervisionar e orientar os professores sobre os procedimentos didático pedagógicos do curso, promovendo ou solicitando os necessários aperfeiçoamentos e correções, articularse com órgãos da administração para fins de assistência vocacional, psicológica e social do aluno, bem como de preparação para sua inserção no mercado de trabalho até questões como acompanhar e orientar as relações interpessoais entre professores, funcionários e alunos, cooperar na divulgação, junto ao corpo docente, discente e técnico-administrativo do curso, das atividades de pesquisa e extensão e promover a articulação do curso com entidades científicas, tecnológicas e de ensino para intercâmbio, troca de experiências e inovações tecnológicas, dentre outras atribuições.

A segunda instituição é uma universidade pública estadual criada em 1976, a partir de institutos isolados de ensino superior que existiam em várias regiões do Estado de São Paulo. Tem 34 unidades em 24 cidades do estado de São Paulo. É uma das três universidades públicas de ensino gratuito e é mantida pelo 
Governo do Estado de São Paulo. A IES pesquisada possui 38.247 alunos em cursos de graduação e 14.431 alunos em cursos de pós-graduação. Oferece 183 opções de entrada na graduação e 149 na pós-graduação. A análise da gestão de curso de graduação terá como referência um dos diversos cursos oferecidos pela IES em uma unidade universitária que teve origem na Faculdade de Filosofia Ciências e Letras, criada pelo governo do Estado em 1958 e que compreende hoje duas unidades universitárias.

A sua estrutura é baseada em departamentos reunidos em Institutos ou Faculdades - unidades universitárias - integrados em campus. Cada unidade universitária possui uma Congregação, órgão deliberativo e normativo em matéria de ensino, pesquisa, extensão universitária e administração, com representação de toda a comunidade universitária.

A diretoria da Unidade Universitária é exercida pelo diretor, auxiliado pelo vice-diretor. 0 Departamento é a unidade básica da estrutura universitária e integra, para efeito de organização didático-científica e administrativa disciplinas afins de um campo do conhecimento. A coordenação de curso de graduação nem a figura do coordenador de curso de graduação aparecem no estatuto e regimento da IES.

Existe uma resolução da Reitoria da IES que dispõe sobre a coordenação de cursos de graduação. Nesta resolução estabelece-se que a coordenação das atividades de cada curso de graduação será exercida, em cada unidade universitária, por um Conselho de Curso, presidido pelo coordenador de curso. Cada Conselho de Curso é composto por representantes docentes e discentes. 0 mandato dos membros do conselho é de dois anos para docentes e de um ano para representantes discentes, permitidas reconduções. O coordenador e vice-coordenador de curso são eleitos pelos membros do Conselho de Curso, dentre os representantes docentes titulares. A resolução que dispõe sobre a coordenação de cursos de graduação define competências e atribuições tanto para o Conselho de Curso de Graduação, quanto para o coordenador e vice-coordenador de curso de graduação.

Dentre as competências do coordenador de curso, destacamos: presidir o Conselho de Curso de Graduação, cumprir e zelar pelo cumprimento das deliberações do Conselho de Curso de Graduação e convocar, periodicamente, reuniões plenárias para discussão das atividades de rotina, bem como para avaliação anual das atividades do curso, e para a elaboração de propostas de alteração ou de reestruturação curricular. As competências do Conselho de Curso são mais amplas e numerosas, envolvendo definir, acompanhar e avaliar a proposta pedagógica do curso, coordenar as ações de ensino de graduação, propor normas para estágios curriculares, trabalhos de conclusão de curso, atividades complementares e atividades acadêmico, científicas e culturais, orientar alunos na matrícula, analisar e aprovar programas para alunos participarem de intercâmbio, coordenar e analisar o processo de avaliação do conteúdo ministrado e do desempenho didático dos decentes, avaliar anualmente o curso, manifestarse nos processos de contratação docente para disciplinas do curso no que diz respeito à definição dos programas e provas, a composição de bancas examinadoras, ao perfil e preparo dos candidatos.

\section{OS MODELOS DE GESTÃO DE CURSOS DE GRADUAÇÃO NAS DUAS UNIVERSIDADES}

Distintas organizações, distintos ambientes, distintas são as formas de dirigi-las na busca de seus objetivos. Os gestores dos cursos, diretor ou coordenador, em maior ou menor grau de intensidade ou atividades sob sua responsabilidade respondem a um objetivo final que é o mesmo, ou seja: fazer com que o ensino e a aprendizagem aconteçam conforme preconizados nos projetos pedagógicos dos cursos.

Entretanto as particularidades e características de cada uma das instituições irá tornar distinta a atuação do gestor.

A primeira delas são as de restrições orçamentárias. Mesmo na instituição privada estudada que não tem como objetivo o lucro financeiro, sua restrição orçamentária está exatamente na potencialização de economia que gera para poder financiar o seu próprio desenvolvimento e atualizações dos seus cursos de graduação, nas suas atividades de extensão e de pesquisa. Embora a gestão do orçamento, neste caso, não caiba ao diretor do curso, muitas vezes impõe-se economias orçamentárias equivocadas uma vez que a decisão de investimento ou de qualquer despesa não rotineira tenha que passar sobre o crivo da Administração Superior da Universidade.

$\mathrm{Na}$ instituição pública, embora as restrições orçamentárias sejam uma realidade, a realização de um orçamento serve como base para o planejamento do ano seguinte. Sofre, é claro, com as dificuldades de repasses do governo, mas consegue decidir sobre o destino dos recursos e priorizá-los. Além disso, a aplicação do recurso deve ser realizada sob pena de que caso não o use, seja retirado no próximo 
exercício. Entretanto o que de fato decidirá o modelo de gestão do curso e a atuação do gestor é a forma de escolha para executar esta tarefa.

Na instituição privada, o processo de escolha do Diretor de Faculdade acontece, geralmente, pela indicação superior que pode ou não ouvir ou consultar a comunidade acadêmica ou aos seus pares. Se de um lado essa conduta facilita a escolha de um gestor alinhado e identificado com a Administração Superior, algumas vezes competências e habilidades podem ser desconsideradas na escolha favorecendo, neste caso, as preferências pessoais dos principais gestores.

Na universidade em questão há a limitação de dois mandatos consecutivos de quatro anos cada um, para todos os seus gestores. De reitor aos diretores de faculdades, os dois mandatos, pelo espírito do regimento quando criado, procurava evitar a perpetuação das pessoas nos cargos de gestão que antes de 1998 e eleições diretas, se julgava à época um inconveniente na renovação e alternativa na condução da universidade e seus cursos.

Na prática o que tem acontecido é que, no que diz respeito à condução dos cursos e os projetos pedagógicos, há uma tendência de centralização das decisões com pouca flexibilidade na elaboração dos mesmos. Todos os focos dos diretores estão no cumprimento de resoluções normativas e normas regulamentadas pela interpretação dada pela Administração Superior da instituição. A obediência aos requisitos do sistema acadêmico procura evitar qualquer decisão que não esteja prevista ou regulamentada. Isso traz uma padronização encaixotada na construção e formatação dos projetos pedagógicos dos cursos e impactam diretamente na gestão. 0 diretor, na maior parte do tempo, atende as demandas superiores sempre com prazos exíguos para o cumprimento e dando atenção a rotina interminável dos cursos para imputá-las no sistema de gestão acadêmico.

O que em princípio deveria ser um facilitador da gestão ocupa um tempo precioso para o desenvolvimento do curso e atuação junto aos alunos, corpo docente e a melhor compreensão do projeto pedagógico e na sua efetividade.

A esse respeito na instituição pública, em função da forma da escolha mais democrática, o coordenador deve possuir características mais mediadoras no processo de gestão. Mesmo eleito com o voto da maioria e sua gestão compartilhada com um Vice- Coordenador e o Conselho, o coloca numa posição mais negociadora. Com decisões tomadas em colegiados e executadas a partir deste aval, a tendência é de que pode haver um entendimento melhor por parte do corpo docente dos objetivos a serem alcançados as limitações de recursos e os caminhos a serem seguidos.

Entretanto, a mediação não é algo simples de ser conseguido e a habilidade do coordenador em relação às pessoas e sua capacidade criativa em indicar caminhos, encontrar atalhos, se relacionar em todos os níveis da instituição, sobretudo no apoio de seus pares consomem boa parte de seu tempo. Em áreas mais ideológicas tais como nas ciências sociais, as ciências humanas, como na economia e no direito, um coordenador identificado com determinado pensamento sempre trará certa desconfiança sobre sua gestão e isso certamente fará com que boa parte de seu tempo seja dedicada a convencer as pessoas a compreenderem suas intenções.

Novamente se retoma a questão: qual o modelo de gestão adequado?

1) Quem assume a gestão precisa certamente conhecer, aplicar e entender as ferramentas de gestão adequadas para a instituição e os objetivos a serem alcançados.

2) Uma instituição de ensino não pode ser medida exclusivamente pelos seus resultados econômicos e financeiros.

3) Os resultados acadêmicos precisam ser ponderados considerando o potencial do seu alunado e a capacidade de transformação, competência e habilidade de seu corpo docente.

4) A estrutura organizacional deve estar aderente ao objetivo estratégico da instituição.

5) As estratégias de ensino podem ser mudadas entendendo que as condições ambientais se alteram e o caminho, em função disso, pode ser mudado.

6) Os objetivos da instituição precisam estar claros para o gestor e seu compromisso com os objetivos.

7) A administração superior precisa estar de mesma forma esclarecida quanto aos objetivos e se portar como a verdadeira patrocinadora da ação dos seus gestores.

Estabelecidos tais pontos é que se desenha o modelo que possa representar a complexidade da instituição ou curso administrado podendo escolher a partir da teoria geral da administração um modelo mais 
mecanicista ou orgânico de gestão de curso, no entendimento de Russo (2004) a administração é orientada pelo projeto político-pedagógico que se manifesta na prática por ações que possam "contribuir para que com os recursos existentes e disponíveis, se produza o máximo de educação possível, ou seja, que a escola atenda o maior número de alunos com a melhor qualidade" (p. 33).

\section{CONSIDERAÇÕES FINAIS}

0 trabalho se propôs a discutir o papel, o perfil e os desafios do coordenador de curso como gestor acadêmico, identificando modelos de gestão em uma universidade pública e em uma universidade privada. Evidencia-se a importância do coordenador de curso de graduação após as recentes políticas públicas para o ensino superior brasileiro, ocorridas desde meados da década de 1990. Não há bibliografia específica que aborde a complexidade do trabalho do coordenador, enquanto gestor educacional. A escassa produção acadêmica sobre esse assunto tem caráter prescritivo-normativo, dificultando uma discussão teórica que trate das especificidades da gestão educacional.

Na maioria dos casos a gestão educacional se vale do paradigma da administração empresarial, tendo por pressuposto a ideia de que administrar uma escola é equivalente à administração de uma empresa qualquer. A partir de Russo (2004) e Goldbarg (1998) trazemos a especificidade da gestão educacional e a premência de se construir uma Teoria da Administração Escolar, alicerçada na educação como direito e na gestão democrática. Ao nos debruçarmos sobre os modelos de gestão de cursos em uma universidade pública e em uma universidade privada, a partir de pesquisa documental e observação participante, percebemos que o modelo de gestão tradicional ainda predomina, seja por questões de estratégia, estrutura organizacional, ambiente externo, objetivos e posicionamento.

\section{REFERÊNCIAS}

[1] Abreu, Bergamini de. Novas reflexões sobre a evolução da teoria administrativa: os quatro momentos cruciais no desenvolvimento da teoria organizacional. Revista de Administração Pública, Rio de Janeiro, v. 16, n. 4, 1982, p. 39-52.

[2] Aktouf, Omar. A administração entre a tradição e a renovação. São Paulo: Atlas, 1996.

[3] Aragão, José Euzébio de Oliveira Souza; França, Carlos Marshal; Zuccolotto, Paulo Antonio da Graça Lima. Avaliação do ensino superior: os desafios para o Coordenador de Curso. In: Aragão, José Euzébio de Oliveira Souza; Escrivão Filho, Edmundo. Introdução à administração: desenvolvimento histórico, educação e perspectivas profissionais. São Paulo: Atlas, 2016, p. 145-160.

[4] Catani, Afrânio Mendes; Oliveira, João Ferreira de. As políticas de diversificação e diferenciação da educação superior no Brasil: alterações no sistema e nas universidades públicas. In: Sguissardi, Valdemar (org.). Educação superior: velhos e novos desafios. São Paulo: Xamã, 2000, p. 63-81.

[5] Ferreira, Ademir Antônio; Reis, Ana Carla Fonseca; Pereira, Maria Isabel. Gestão empresarial: de Taylor aos nossos dias. São Paulo: Pioneira, 1997.

[6] Franco, Édson Raymundo Pinheiro. Funções do coordenador de curso: como construir o coordenador ideal. Brasília: ANMS, 2002. Disponível em http://www.abmes.org.br /public/arquivos/publicacoes/Abmescaderno8.pdf. Acesso em 17 ago. 2017.

[7] Goldbarg, Marco César. Educação e qualidade: repensando conceitos. Revista Brasileira de Estudos Pedagógicos, Brasília, v. 79, n. 193, 1998, p. 35-62.

[8] Jacobucci, Daniela Franco Carvalho; Jacobucci, Giuliano Buzá. Correndo na esteira rolante: a experiência de coordenar um curso de graduação em uma instituição de ensino superior privada. Olhar do Professor, Ponta Grossa, v. 11, n. 1, 2008, p. 81-101. Disponível em http://www.uepg.br/olhar_de_professor. Acesso em 17 ago. 2017.

[9] Maximiano, Antonio César Amarú. Teoria geral da administração: da revolução urbana à revolução digital. São Paulo: Atlas, 2012.

[10] Motta, Paulo Roberto. Gestão contemporânea: a ciência e a arte de ser dirigente. Rio de Janeiro: Record, 1999.

[11] Noguez, José Hiram S; Tillmann, Alfredo Luiz da Costa; Duarte, Glaucius Décio. Os saberes e práticas do coordenador de curso de graduação da Universidade Federal de Pelotas. Reunião Científica Regional da Anped, 11, 2016. Anais ... Curitiba: Anped, 2016. Disponível em http://www.anpedsul2016.ufpr.br/trabalhos-completos-eixo8ensino-superior. Acesso em 17 ago. 2017.

[12] Nunes, Thalita Pimentel; Leão, Jacqueline Oliveira. O coordenador de curso de instituição de ensino superior privado como ferramenta de gestão estratégica universitária: um estudo de caso em uma instituição de Montes 


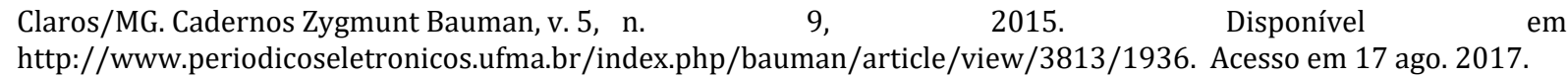

[13] Pereira, Maria Isabel; Santos, Silvio Aparecido dos. Modelo de gestão: uma análise conceitual. São Paulo: Pioneira Thomson Learning, 2001

[14] Robbins, Stephen P. O processo administrativo: integrando teoria e prática. São Paulo: Atlas. 1978.

[15] Russo, Miguel Henrique. Escola e paradigmas de gestão. EccoS - Revista Científica, São Paulo, Uninove, v. 6, n. 1,2004, p. 25-42.

[16] Silva, Reinaldo O. Teorias da administração. São Paulo: Thomson Pioneira, 2001. 


\section{Capítulo 11}

Satisfação no trabalho e rotatividade de professores em escolas públicas estaduais

\section{Marcela Iessa Schmidlin \\ Graziela Sapienza}

Resumo: insatisfação do professor com o trabalho interfere em sua saúde física e mental, provoca absenteísmo, rotatividade entre escolas e influencia no processo de ensino e aprendizagem. 0 objetivo deste estudo foi identificar através da análise de documentos escolares variáveis relacionadas à satisfação no trabalho comparando com a rotatividade dos professores em instituições escolares. Foram incluídos no estudo dados dos professores que lecionavam em duas escolas estaduais de Curitiba (PR). Os resultados mostraram que a insatisfação dos professores pode aparecer como falta ao trabalho, pouco interesse em se desenvolver profissionalmente e afastamento médico-psicológico. As escolas apresentaram alta rotatividade de professores devido ao regime de trabalho, prejudicando a satisfação e o envolvimento do professor com a escola, consequentemente com os alunos e o processo de ensino-aprendizagem.

Palavras-chave: Satisfação no trabalho; rotatividade dos professores na escola; saúde do professor.

*0 trabalho foi apresentado na II Jornada Ibero-Americana de Pesquisas em Políticas Educacionais e Experiências Interdisciplinares na Educação (II Jorneduc) 


\section{INTRODUÇÃO}

0 grau de satisfação no trabalho do docente tem relação direta com seu estado mental, com a qualidade e o entusiasmo do seu trabalho e com o zelo por sua saúde física e mental. (Fuming \& Jiliang, 2007). Altos níveis de insatisfação no trabalho geram estresse ocupacional e podem dar origem às doenças cardíacas, doenças alérgicas e burnout, além de levar a problemas no desempenho profissional e dificuldades em agir pró-ativamente (Martins \& Santos, 2006).

A insatisfação do professor pode ser verificada, por exemplo, através de atrasos ou faltas no trabalho, não entrega de tarefas, pouco interesse em se desenvolver profissionalmente. 0 professor insatisfeito apresenta uma percepção inadequada de fatores estressores que podem levar a transtornos psicológicos e psiquiátricos, como ansiedade e depressão e que, por sua vez, levam aos afastamentos da sala de aula, prejudicando seu desempenho laboral e o processo de ensino e aprendizagem, culminando em um rendimento rebaixado por parte dos alunos (Costa \& Rocha, 2013). Características da instituição escolar, incluindo o local de trabalho, a disponibilidades de recursos e as regras da instituição podem tornar o local de trabalho agradável ou desagradável o que, nesse último caso, reduz a satisfação de quem trabalha nesse local.

A rotatividade pode ser definida como a entrada e saída de um profissional de uma organização, de forma voluntária ou involuntária. Toda organização possui rotatividade e, esta, ode ser compreendida como positiva, na medida em que funcionários desnecessários deixam a organização, ou negativa, quando pessoas estratégicas e competentes para o cargo em questão abandonam a organização (Robins, 2002).

Assim a insatisfação no trabalho e a rotatividade do professor nas escolas estão relacionadas a muitos fatores, tais como sua saúde física e mental, comprometimento no trabalho, taxas de absenteísmo, o plano de carreira e a contratação do docente. (Assunção, Barreto \& Gasparini, 2005; Fuming \& Jiliang, 2007; Skaalvik \& Skaalvik, 2011)

Conhecendo melhor algumas variáveis envolvidas nessa relação, será possível propor ações para desenvolver habilidades desses educadores e aumentar seu grau de satisfação diminuindo a rotatividade do profissional nas escolas. Também se espera identificar meios de proporcionar maior bem-estar para os professores, identificando possíveis fatores estressores escolares que prejudicam a permanência de um professor numa mesma instituição.

\section{MATERIAIS E MÉTODO}

Participantes: Foram incluídos no estudo informações de documentos escolares de todos os professores que lecionavam no ensino médio e/ou fundamental de duas escolas (Escola 1 e Escola 2) no ano de 2013.

Critérios de inclusão: os professores poderiam estar em atividade ou em licença-saúde e deveriam ter pelo menos 01 ano de experiência docente. Foram excluídos da pesquisa dados dos professores com menos de 01 ano de experiência docente.

Instrumento: Com base em variáveis descritas na literatura como importantes para avaliar a satisfação do professor (Assunção et al., 2005; Borges \& Daniel, 2009; Fuming \& Jiliang, 2007; Martins \& Santos, 2006; Petillon, 1983; Pocinho \& Fragoeiro, 2012; Skaalvik \& Skaalvik, 2011), foi criado um Instrumento de Coleta de Dados. 0 instrumento foi dividido em duas etapas: 1) Infraestrutura - com 24 aspectos que deveriam ser observados e registrados em relação à presença ou ausência nas escolas em questão; e 2) Informação sobre os Professores: com itens relacionados à Formação; Experiência e Ausência do professor ao trabalho que foram coletados em documentos escolares.

Procedimentos:

Fase 1 - Construção do Instrumento. As variáveis identificadas pela literatura foram usadas para a construção do Instrumento de Coleta de professor. (Assunção et al., 2005; Borges \& Daniel, 2009; Fuming \& Jiliang, 2007; Martins \& Santos, 2006; Petillon, 1983; Pocinho \& Fragoeiro, 2012; Skaalvik \& Skaalvik, 2011)

Fase 2 - Seleção das escolas. Foram sorteadas duas escolas a partir de lista que consta no site da Secretaria de Educação. A pesquisadora entrou em contato com a direção, apresentou a pesquisa e, após a autorização, iniciou a coleta de dados. 
Fase 3 - Coleta de dados. Foram realizadas visitas as escolas, no período de novembro de 2013 a abril de 2014 para observação das escolas e levantamento de informações sobre os professores. Foram necessários 4 dias na Escola 1 e 7 dias na Escola 2 para todo o levantamento de dados.

Fase 4 - Organização dos dados e discussão dos resultados. Os dados coletados foram organizados numa planilha do Excel e, posteriormente, em tabelas, para facilitar a visualização e a discussão dos resultados.

\section{RESULTADOS}

\subsection{Dados sobre Infraestrutura das Escolas}

Em relação aos dados acerca da Infraestrutura, observa-se que não houve grandes diferenças entre as Escolas 1 e 2 (Tabela 1). Ambas possuem itens de infraestrutura considerados importantes para o trabalho do professor e para o funcionamento adequado das escolas. Mas vale a pena destacar que a Escola 2 não possui ventiladores em sala de aula.

Tabela 1

Comparação Entre Itens de Infraestrutura das Escolas 1 e 2

\begin{tabular}{|l|c|c|}
\hline \multicolumn{2}{|l|}{ Estrutura física das escolas } & Escola 1 2 \\
\hline $\begin{array}{l}\text { Refeitório/ Cozinha para o professor/ 2 Banheiros exclusivo } \\
\text { para os professores (masculino e feminino) }\end{array}$ & Possui & Possui \\
\hline Biblioteca/Laboratório de informática e de ciências. & Possui & Possui \\
\hline Sala para os professores & Possui & Possui \\
\hline $\begin{array}{l}\text { Salas especiais (teatro, jogos, música, dança e Laboratório de } \\
\text { matemática). }\end{array}$ & Possui & Não possui \\
\hline Quadra coberta/ Quadra não coberta & Possui & Possui \\
\hline $\begin{array}{l}\text { Salas de aula com televisão, mesa e cadeira para o professor } \\
\text { e um equipamento de projeção móvel. }\end{array}$ & Possui & Possui \\
\hline Ventiladores nas salas de aula & Possui & Não possui \\
\hline $\begin{array}{l}\text { Materiais educacionais (ex.: jogos, mapas, corpo humano de } \\
\text { plástico), giz de quadro, apagador, impressora e rede sem fio } \\
\text { disponíveis. }\end{array}$ & Possui & Possui \\
\hline
\end{tabular}

\subsection{DADOS SOBRE OS PROFESSORES}

Foram analisados dados de professores que lecionavam em ensino fundamental ou médio, sendo 34 da Escola 1 e 60 da Escola 2. Em relação ao tempo em que permanecem nas escolas, verificou-se na Escola 1 que $19(56 \%)$ professores estavam há menos de 1 ano na instituição, $9(26 \%)$ tinham entre 2 e 5 anos na escola, 6 (18\%) profissionais estavam na mesma instituição entre 6 e 10 anos e nenhum professor estava há mais de 10 anos lecionando na mesma instituição. Na Escola 2, lecionavam na instituição há menos de um ano 28 (47\%) professores, entre 2 e 5 anos 11 (20\%), de 6 a 10 anos 14 (23\%) e $6(10 \%)$ professores estavam há mais 10 anos na mesma instituição;

Foram analisadas as faltas dos professores nas duas escolas. Os professores da Escola 1 totalizaram, juntos, 243 faltas. Deste total, $91 \%(n=221)$ das faltas foram justificadas através de atestados e $9 \%(n=22)$ não apresentaram nenhum tipo de justificativa. As ausências que apresentaram atestados eram, em sua maioria, por doença $(96 \%, n=213)$, mas 08 atestados se referiam a outros motivos como, por exemplo, acompanhamento de menor ou de familiar. Dos 213 atestados entregues, grande parte apresentava somente o pedido de afastamento por algum tempo determinado, porém não indicava diagnóstico ou motivo etiológico. Entre os que apresentavam, verificou-se que entre as doenças mais recorrentemente usadas como razão da licença estavam aquelas relacionadas ao aparelho circulatório e respiratório.

Já os professores da Escola 2 totalizaram 828 faltas, sendo 75\% (n=622) justificadas e 25\% (n=206) sem justificada. Em $85,5 \%(n=532)$ dos atestados apresentados constavam como motivo alguma doença e em $14,5 \%(n=90)$ estavam outros motivos. Assim como na Escola 1, a maioria dos atestados apresentaram apenas o pedido de afastamento sem indicar a razão diagnosticada, mas na Escola 2, entre as doenças mais presentes estavam as do aparelho respiratório e transtornos mentais e comportamentais.

A Tabela 2 exibe informações sobre os professores referentes a algumas variáveis que podem influenciar diretamente na satisfação e gerar rotatividade do professor na escola. Essas informações foram separadas de acordo com o vínculo que os professores têm com as escolas, sendo "Quadro Próprio Magistério" (QPM) e "Regime Especial Professor" (REPR). 
Tabela 2: Comparação Entre Dados dos Professores Divididos por Escola e por Forma de Contratação.

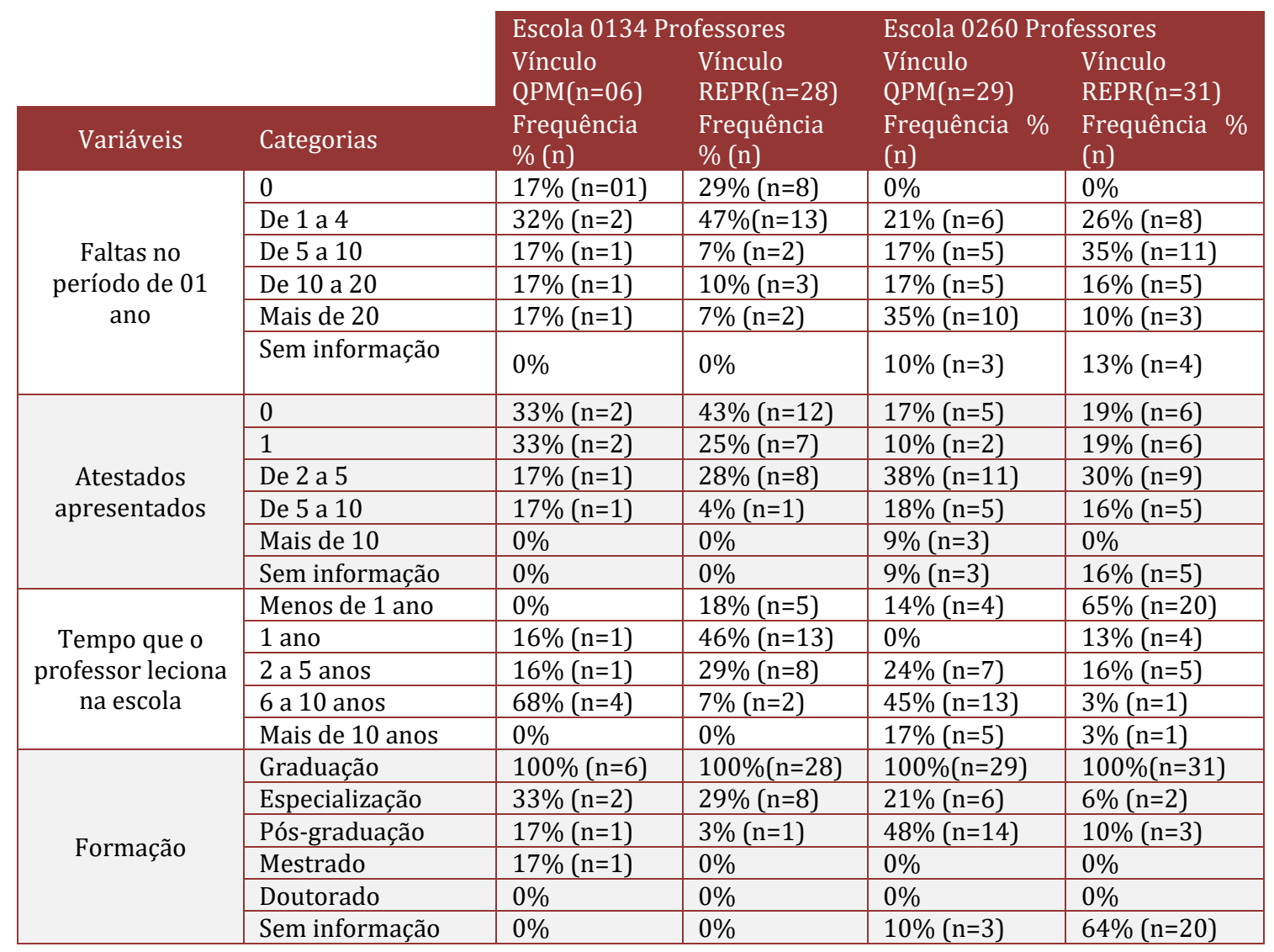

\section{DISCUSSÃO}

Segundo Neto, Karino, Jesus e Andrade (2013) uma infraestrutura escolar favorável para o professor abrange materiais didáticos, equipamentos e estruturas físicas apropriadas. Nas escolas onde foi realizada a pesquisa nota-se uma infraestrutura adequada: ambas possuem salas para os professores, acesso a micro-ondas e geladeira, apagador, giz, materiais didáticos de apoio (mapas, jogos didáticos), banheiros exclusivos para os professores, laboratórios, acesso à internet sem fio, salas de computadores, etc.

Pedro e Peixoto (2006) consideram que o conceito de satisfação do docente envolve componentes afetivos que se relacionam à autoestima, ao envolvimento e ao comprometimento no trabalho; esse último indica o grau de atenção, de esforço e cuidado que a pessoa transfere ao realizar algo. Neste trabalho, o comprometimento no trabalho foi relacionado às faltas, à quantidade de cursos que o docente realizou durante um ano para desenvolvimento do seu trabalho e ao complemento à graduação (especialização, mestrado ou doutorado). Percebeu-se que embora os professores da Escola 1 tenham faltado menos em suas funções também demonstraram menor comprometimento, já que se envolveram menos em cursos de formação ou aperfeiçoamento e poucos possuem pós-graduação (especializações, mestrado ou doutorado). Já os docentes da Escola 2, mostraram-se mais comprometidos no que se refere ao aprimoramento em sua carreira profissional e em suas funções como professor.

Durante o processo de coleta de dados nas escolas, ficou evidente que a Escola 2 apresentava uma organização maior em relação aos documentos dos professores e este fato facilitou a coleta das informações. Parece que essa organização favorece para um melhor relacionamento entre instituição e professores, refletindo em um comprometimento desses profissionais com seus trabalhos na instituição e em um interesse em seu desenvolvimento profissional. Além dos professores, verificou-se que os responsáveis (diretores) da escola 2 também estavam fazendo algum tipo de aperfeiçoamento em relação a sua carreira. Levanta-se a hipótese de que estes, como representantes de hierarquia, oferecem modelo e motivação para os professores que compõem o quadro de funcionários desta escola.

Um fator que chamou atenção durante a coleta de dados nas duas escolas foi a grande rotatividade dos professores nas instituições. Na Escola 1, 56\% (n=19) dos professores e na Escola 2, 47\% (n=28) dos 
docentes permanecem 1 ano ou menos no estabelecimento escolar. A rotatividade dos professores na instituição escolar dificulta a formação do vínculo do professor com a instituição no geral, mas principalmente com a equipe pedagógica e com os alunos, o que interfere no rendimento do aluno e no desempenho do próprio professor em suas funções.

Alguns dados aqui obtidos podem ser discutidos em dois caminhos. Primeiro em relação à satisfação da profissão do professor integrando sua saúde física e psicológica. E em segundo, no que se refere às políticas públicas educacionais quanto ao regime de contratação (QPM e REPR) dos professores em Curitiba.

Em relação à saúde física e psicológica, nas escolas incluídas na pesquisa, verificou-se que os professores apresentavam uma grande quantidade de atestados médicos. Na escola 2, 68\% dos professores forneceram para a escola um ou mais atestados e, destes, 33\% entregaram até 5 atestados durante o ano. Já a escola 1, 82\% dos docentes entregaram 1 ou mais atestados e, entre eles, $26 \%$ entregaram de 2 a 5 atestados durante o ano de 2013. Esses dados indicam uma alta taxa de absentismo, revelada através dos atestados. E podem indicar, por outro lado, que possivelmente o trabalho dos docentes está abalando suas vidas e se refletindo no surgimento de doenças. De qualquer forma, esses dados contribuem para a insatisfação dos professores com seu trabalho conforme destacam Assunção et al. (2005).

$\mathrm{O}$ autor considerou que pessoas satisfeitas adotam atitudes mais positivas, possuem taxas de absentismo reduz \idas, podendo ser este um fator de decisão para a permanência na organização/instituição onde desempenham a sua função. Atualmente, pesquisas mostram que muitos professores solicitam afastamento profissional por problemas de saúde mental ou física (Assunção et al., 2005). A alta rotatividade de professores parece ter relação com o elevado índice de abandono da profissão ou do afastamento temporário desses profissionais, geralmente por problemas de saúde, muitas vezes, relacionados ao próprio trabalho docente (Schneider \& Almeida, 2014).

Por outro lado, os resultados aqui obtidos podem ser discutidos no âmbito das políticas públicas que norteiam a contratação docente no Paraná. A Rede Estadual de Ensino do Paraná regulamenta no Plano de Carreira que o ingresso do docente deve ser por concurso público através do qual o regime de contratação que é denominado Quadro Próprio Magistério (QPM). Entretanto, na prática, os professores também são contratados em Processo Seletivo Simplificado (PSS) ou Regime Especial Professor (REPR). Essa prerrogativa de contratação precária está prevista na Lei Complementar n. 108/05 (Paraná, 2005). Por meio dessa lei, o Estado do Paraná realiza contratação temporária.

Nas duas escolas pesquisadas, os professores de vínculo REPR predominam em relação aos professores cujo vínculo é QPM. Na escola 1, 82,5\% dos professores são contratados pelo processo simplificado (REPR) e na escola 2, 51,6\%. Esses dados indicam que no próximo ano, na escola 1 praticamente todo o quadro de professores será mudado e na escola 2 pelo menos metade dos docentes será trocado. Esse regime, instável modifica constantemente o trabalho do professor e levar à desmotivação, além da dificuldade do professor em conhecer, se identificar e se engajar diante dos objetivos da escola, da comunidade e dos alunos. 0 professor de regime PSS não cria uma identidade com o colégio que leciona (Lino, 2012), pois sabe que será difícil permanecer na mesma escola.

Já os professores contratados sob o regime REPR são condicionados a um trabalho fragmentado, pois recebem uma determinada carga horária de aulas que podem ser ministradas em diferentes escolas (Lino, 2012). A contratação nesse regime tem o prazo de um ano e, dessa forma, os docentes devem refazer o processo todo ano. Caso o professor queira permanecer na mesma escola, deve refazer o processo e solicitar novamente a vaga. Se a vaga estiver livre, o professor efetiva sua entrada na escola. Assim, o professor não possui autonomia para se fixar e permanecer em determinado colégio (conforme seu interesse e vontade) e fortalecer vínculos com a administração e com o corpo discente.

Os planos de carreira da Rede Estadual do Paraná conjugam elementos de progressão e evolução da remuneração ao longo das carreiras. Essas progressões são baseadas na titulação, no tempo de serviço, na avaliação de desempenho e na formação continuada que consta no "Plano de Desenvolvimento da Educacional (PDE)", um programa de formação de dois anos de duração, fornecido pelo estado, no qual o professor realiza estudos e um projeto de intervenção nas escolas. Os professores contratados temporariamente por REPR, não têm direito aos benefícios da carreira (Souza, Gouveia, Abreu, Schneider, Ribeiro, \& Souza, 2012).

Por outro lado, o plano de carreira influencia na motivação do professor para melhorar seu currículo. Isso porque, na escola 1, 29\% dos professores REPR possuem uma especialização e 3\% possui mestrado ou doutorado, enquanto 33\% dos docentes QPM possuem especialização e 17\% possuem uma pós-graduação 
strictu senso. Na escola 2 , também é possível notar que os professores do regime QPM se dedicam mais a complementar sua formação, visto que $6 \%$ dos profissionais cuja vinculação é REPR realizou uma especialização e $10 \%$ desses docentes possuem mestrado ou doutorado, já $21 \%$ dos docentes QPM cursaram uma especialização e $48 \%$ mestrado ou doutorado.

Em relação às faltas, em ambas as escolas, os docentes do regime QPM faltam mais dos que os de regime REPR. 69\% dos docentes de vínculo QPM da escola 2 tiveram mais de 5 faltas em 2013 e 61\% dos professores do regime REPR faltaram 5 ou mais vezes. Na escola 1. $50 \%$ dos professores QPM e $29 \%$ dos profissionais REPR faltaram 5 ou mais vezes. Talvez isso ocorra devido à estabilidade dos profissionais QPM no emprego e na escola. Outra possibilidade é que a satisfação profissional progride com o passar dos anos lecionados (Pedro \& Peixoto, 2006).

Independente de qual explicação esteja mais perto da verdade, a satisfação do professor relacionada à sua saúde ou ao regime de contratação, a grande rotatividade dos professores nas escolas, a alta taxa de absenteísmo decorrente das faltas justificáveis e injustificáveis e a falta de comprometimento no trabalho, traduz um professor insatisfeito, o que influencia na sua permanência na instituição em que trabalha. Um professor com insatisfação pode não estabelecer boas relações com os colegas de trabalho, apresentará baixa motivação em suas tarefas, não procurará novas formas de ensino e de atualização e pode não ter autocontrole emocional diante da turma, levando a problemas de comportamento na sala de aula e ao baixo rendimento acadêmico.

\section{CONCLUSÃO}

Este trabalho visou identificar as relações entre a satisfação do professor e a grande rotatividade dos professores nas instituições. Para isso, foi feito uma coleta de dados documentais em duas escolas. Assim, foi levantada duas hipóteses para a compreensão dessa relação: a primeira em relação à satisfação do professor integrado a sua saúde física e psicológica e a segunda no que se refere às políticas públicas educacionais quanto ao regime de contratação (QPM e REPR) dos professores em Curitiba. As duas hipóteses afetam diretamente a rotatividade dos professores nas escolas.

Diante dessas considerações, este estudo atingiu o seu objetivo. Foi possível pesquisar e encontrar dados relevantes que influenciaram a satisfação do professor. Os regimes de contratação atualmente disponíveis na rede estadual do Paraná, à grande quantidade de atestados e doenças que afetam os docentes e ao alto nível de rotatividade dos professores foram evidenciados nas duas escolas.

Os resultados desse trabalho sugerem que novas pesquisas sejam feitas. A elaboração de uma proposta de intervenção que vise trabalhar diretamente a rotatividade dos professores nas escolas, evidenciado as causas da insatisfação do profissional e objetivando uma diminuição dos atestados (doenças) e do número de faltas é uma possível extensão desse trabalho.

\section{REFERÊNCIAS}

[1] Assunção, A.A., Barreto, S.M. \& Gasparini, S.M. (2005). O professor, as condições de trabalho e os efeitos sobre sua saúde. Educação e Pesquisa, 31 (2), 189-199.

[2] Borges, S.L. \& Daniel, F. (2009). Satisfação profissional dos docentes: uma abordagem sobre instrumentos de medida. Interações, 9 (16), 101-130.

[3] Fuming, X., Jiliang, S. (2007). Research on job satisfaction of elementary and high school teachers and strategies to increase job satisfaction. Chinese Education and Society, 40 (5), 86-96.

[4] Lino, A.V. (2012). Políticas públicas e a precarização da educação pelo contrato PSS no Paraná. LENPES-PIBID de Ciências Sociais-UEL, 1 (2).

[5] Martins, M.C.F., \& Santos, G.E. (2006). Adaptação e validação de construto da Escala de Satisfação no Trabalho. Psico-USF, 11 (2), 195-205.

[6] Neto, J.J.S., Karino, C.A., Jesus, G.R. \& Andrade, D.F. (2013). A infraestrutura das escolas públicas brasileiras de pequeno porte. Revista do Serviço Público Brasília, 64 (3), 377-391.

[7] Paraná (2005). Lei Complementar n. 108 de 18 de maio de 2005 . Retirado de: http://celepar7cta.pr.gov.br/seap/legrhv1.nsf/5199c876c8f027f603256ac5004b67da/c58a49f6c28c0cd583257014 004a4653?OpenDocument. Acesso em: 01 Junho 2014. 
[8] Pedro, N. \& Peixoto, F. (2006). Satisfação profissional e auto-estima em professores do 2.. e 3.ำ ciclo do Ensino Básico. Análise Psicológica, 24 (2).

[9] Petillon, H. (1983). The diagnostic of social relationships in school. Studies in Educational Evaluation, 9 (2), 223-237.

[10] Pocinho, M. \& Fragoeiro, J.G. (2012). Satisfação dos docentes do ensino superior. Acta Colombiana de Psicología, 15 (1), 87-97.

[11] Robbins, S.P. (2002). Comportamento organizacional. 9ª ed. São Paulo: Prentice Hall.

[12] Souza, A.R., Gouveia, A.B., Abreu, D.C., Schneider, G., Ribeiro, J.Q.G. \& Souza, M. N. (2012). Planos de carreiras da rede estadual de ensino do Paraná e da rede municipal de ensino de Curitiba: um exercício comparativo. Revista Educação em Foco,15 (19), 301-330.

[13] Schneider, M.P., \& Almeida, M.L.P. (2014). Entrevista com o professor doutor Júlio Emilio Diniz-Pereira: a formação de professores no brasil. Roteiro, Edição Especial, 231-242. Retirado de: www.editora.unoesc.edu.br Acessado em: 15/09/2015

[14] Skaalvik, E.M. \& Skaalvik, S. (2011). Teacher job satisfaction and motivation to leave the teaching profession: relations with school context, feeling of belonging, and emotional exhaustion. Teaching and Teacher Education, 27 (6), 1029-1038. 


\section{Capítulo 12}

\section{A compreensão dos professores de escolas públicas}

acerca da progressão continuada

\section{Gilvânia Guedes Teixeira \\ Horácio Medeiros Júnior \\ Vânia Aparecida Calado}

Resumo: Este trabalho tem como objetivo investigar como os professores de uma escola municipal de Parnamirim/RN compreendem a política pública de Progressão Continuada, verificar se a formação inicial qualifica esses professores acerca do tema bem como analisar se a formação continuada e a rede municipal de ensino possibilitam a capacitação desses docentes a respeito da referida política. Para isso, foi realizada uma pesquisa com quatro professores dos anos iniciais e finais do ensino fundamental, utilizando-se de observações não-participantes e entrevista semiestruturada com os quatro professores participantes após as observações. As entrevistas foram transcritas e analisadas a partir da análise de conteúdo. Os resultados indicam que tanto a formação inicial, quanto a continuada não abordaram a política pública Progressão Continuada. Conclui-se que a fonte de conhecimento desses profissionais acerca das políticas educacionais se dá a partir da prática já que a universidade e o poder público não fornecem formação aos professores. É importante que a Psicologia estude as políticas educacionais para compreensão das reverberações delas no processo ensinoaprendizagem, como também para não patologização de demandas que surgem decorrentes de dificuldades de comportamento e aprendizagem. Sugere-se a realização de pesquisa-ação que possibilite a formação continuada dos professores acerca da política pública Progressão Continuada.

Palavras-Chave: Progressão Continuada, Psicologia Escola, Fracasso escolar, Política Pública 


\section{INTRODUÇÃO}

Alguns autores explicitam que há um autoritarismo na implementação de políticas públicas na Educação, embora haja complexidades em seu processo, predomina a ausência de discussão por parte daqueles que as concretizarão (professores e gestores da educação) e a desconsideração de seus saberes, suas possibilidades e opiniões (SOUZA, 2007; VIEGAS, 2002).

Este artigo objetivou investigar uma das problemáticas da política pública progressão continuada, tema tão discutido sobre sua eficácia nos meios teóricos, porém pouco debatido entre os agentes executores dessa política.

A pesquisa em psicologia acerca desse tema faz-se importante como maneira de compreender a relação das políticas públicas com o processo de aprendizagem para não patologizar as demandas atendidas por psicólogos tradicionalmente, em função de problemas de aprendizagem e de comportamento, assim como afirma Souza $(2007$, p. 1) as reflexões e informações sobre tal relação "oferecem-nos elementos para investigarmos, compreendermos e atuarmos junto aos envolvidos na produção e manutenção das queixas escolares (crianças/adolescentes, suas famílias e escolas), individualmente e em suas inter-relações". Além disso, buscou-se identificar através dessa pesquisa não só as limitações da rede pública de ensino, mas também as potencialidades encontradas no decorrer da investigação bibliográfica, através do resgate histórico realizado sobre a progressão continuada, bem como no campo pesquisado.

\subsection{BREVE HISTÓRICO NO BRASIL SOBRE POLÍTICA PÚBLICA EM EDUCAÇÃO COM FOCO NA PROGRESSÃO CONTINUADA}

Segundo Azanha (2004) a educação brasileira nem sempre foi considerada um problema nacional. De 1549 a 1759 esteve na mão dos jesuítas todo o cenário educacional do país. Após a expulsão deles passouse a notar a extrema insuficiência de mestres que pudessem suprir essa falta o que ocasionou na abertura de uma grande lacuna na educação nacional. Após isso, no início do século XIX, com a chegada da família real às terras brasileiras, a educação superior passou a receber maior atenção, entretanto a popular continuou sendo deixada de lado. Apenas na década de 20 a educação do país, que até então era motivo de discussões isoladas e inconstantes, passou a ser motivo de maior preocupação e percebida como problema nacional.

Antes de 1998, ano que houve a implantação do Regime de Progressão Continuada em toda a rede pública de ensino no estado de São Paulo, houve outras tentativas de mudança nas políticas educacionais em prol da diminuição das reprovações, principalmente na primeira série, e do abandono escolar pelos alunos. Entre essas tentativas estão inclusas, segundo Viégas (2009, p. 154), "a Reforma do Ensino Primário, em 1968; e o Ciclo Básico, em 1985". No ano de 1995, Mário Covas assumiu o Governo do Estado de São Paulo e junto com e sua equipe da Pasta Educacional implantaram um conjunto de políticas educacionais que tinham como objetivo solucionar esses problemas. Dentre essas políticas insere-se a Progressão Continuada (LEITE, 2007).

Semelhante ao Ciclo Básico, a Progressão Continuada teria um ciclo de 8 anos. Essa política pública de educação, resumidamente, consiste em extinguir do ensino fundamental a reprovação e dividi-lo em dois ciclos os quais teriam 4 anos cada. Apenas no último ano de cada um deles o aluno poderia ser reprovado, não passando para a série seguinte (VIÉGAS, 2009).

A autora também apresenta a justificativa mais acentuada do relatório do Conselho Estadual de Educação (CEE) para a implementação dessa política, afirmando que mudanças desse tipo deve trazer benefícios tanto para o ponto de vista pedagógico como para o econômico, por outro lado, o fim da retenção e a esperada redução no índice de evasão deve representar otimização desses recursos para melhorar o atendimento à população. "A repetência constitui um pernicioso 'ralo' por onde são desperdiçados preciosos recursos financeiros da educação. 0 custo correspondente a um ano de escolaridade de um aluno reprovado é simplesmente um dinheiro perdido" (CEE, 1997, p. 151-152 apud Viégas, 2002, p. 22).

Atualmente, a Lei no 11.274 de 6 de fevereiro 2006, que altera a redação dos Artigos 29, 30, 32 e 87 da Lei no 9.394, de 20 de dezembro de 1996, implementa:

Art. 32. 0 ensino fundamental obrigatório, com duração de 9 (nove) anos, gratuito na escola pública, iniciando-se aos 6 (seis) anos de idade, terá por objetivo a formação básica do cidadão [...] § $2^{\mathrm{o}}$ Os estabelecimentos que utilizam progressão regular por série podem adotar no ensino fundamental o regime de progressão continuada, sem prejuízo da avaliação do processo de ensino-aprendizagem, observadas as normas do respectivo sistema de ensino (BRASIL, 2006, p. 1). 
Sendo assim o ensino fundamental, agora com 9 anos de duração, divide-se em anos iniciais, com 5 anos de duração, e anos finais, com 4 anos de duração. 0 primeiro de 6 a 10 anos de idade e o segundo de 11 a 14 anos de idade (BRASIL, 2009).

Segundo a Portaria de Avaliação no 001/2007 que estabelece as Normas de Avaliação da Aprendizagem Escolar da Educação Básica do município de Parnamirim, a avaliação nos $1^{\circ}, 2^{\circ}$ e $3^{\circ}$ anos do Ensino Fundamental visará ao acompanhamento do desempenho do aluno, sem fins de retenção e ocorrerá por meio de relatórios analíticos. E só a partir do $4^{\circ}$ ano do Ensino Fundamental, para fins de registro dos resultados, adotar-se-á uma escala de 0 (zero) a 10 (dez).

A falta de compreensão dos docentes a respeito dessa política é capaz de invalidar todo o projeto pensado para resolução das problemáticas educacionais. Então, onde a comunidade educacional pode adquirir conhecimentos sobre essa política? As possibilidades existentes são: a formação inicial e a formação continuada. A respeito da formação inicial de professores, sabe-se que ainda existe um grande déficit no que diz respeito às práticas pedagógicas. Em artigo, Bisconsini, Flores e Oliveira $(2016$, p. 1) citam o lugar de responsabilidade na formação desses profissionais que tem os docentes como também todo o processo formativo: "é nesse momento da formação que o futuro professor adquire os conhecimentos científicos e pedagógicos e as competências necessárias para enfrentar a carreira docente". É importante frisar a diferença entre a formação que o próprio professor busca através de especializações, atualizações, mestrados e doutorados, da formação continuada que será tratada nesse artigo, a qual diz respeito às capacitações oferecidas pelo poder público.

\subsection{METODOLOGIA}

Este trabalho é uma pesquisa descritiva-exploratória, com ênfase qualitativa que utilizou como ferramentas de coleta de dados uma entrevista semiestruturada como instrumento para obtenção de dados. Para Silveira e Córdova (2009, p. 32) "a pesquisa qualitativa preocupa-se, portanto, com aspectos da realidade que não podem ser quantificados, centrando-se na compreensão e explicação da dinâmica das relações sociais". Com a finalidade de uma pesquisa mais aprofundada, utilizou-se de um estudo de caso, que "consiste na observação detalhada de um contexto, ou indivíduo, de uma única fonte de documentos ou de um acontecimento específico" (MERRIAM, 1988 apud Bogdan; Biklen, 1994, p. 89). Empregou-se a observação não-participante como postura perante o campo, significando que os pesquisadores procuram não interferir nos fatos que ocorrem. A entrevista foi feita com quatro professores voluntários, sendo dois dos ciclos iniciais e dois dos ciclos finais. A observação não-participante se deu através de três visitas em sala de aula para cada professor. 0 uso do gravador fez-se necessário para auxiliar os pesquisadores a armazenar e preservar o máximo de informação com precisão, como também a análise dos dados colhidos nas entrevistas. Por fim, favoreceu também para captar dados, que um gravador não fornece, o uso de diários de campo.

A análise dos dados foi realizada após escuta dessas gravações, transcrição das entrevistas, releitura dos diários de campo, leitura flutuante, além do desenvolvimento de duas categorias de codificação, são elas "A formação dos professores" e "A compreensão dos professores a partir da prática". De acordo com Bogdan e Biklen (1994), as categorias constituem um meio de classificar dados descritivos. Portanto, após a classificação de todos os dados, entrevistas, escuta das gravações e diários de campo, houve uma análise crítica e interpretação a partir do referencial teórico e de levantamento bibliográfico com elaboração das categorias, onde foram selecionados os trechos utilizados de acordo com os objetivos da pesquisa. Os participantes foram categorizados de acordo com sua profissão atribuindo números alfanúmericos de ordem aleatória com o objetivo de preservar a identidade desses indivíduos. Como método de análise foi utilizada a análise de conteúdo, que segundo Mozzato e Grzybovski (2011, p. 734) "é um conjunto de técnicas de análise de comunicações, que tem como objetivo ultrapassar as incertezas e enriquecer a leitura dos dados coletados".

A instituição foi escolhida devido ao fato de ofertar o ensino fundamental I e II. Essa condição é de extrema importância já que o tema Progressão Continuada atinge apenas esse período escolar. Especificamente essa pesquisa objetivou investigar se a formação inicial qualifica os professores acerca da política pública Progressão Continuada e se a formação continuada oferecida pela rede municipal de ensino possibilita a capacitação para os docentes a respeito desta política. Vale salientar que essa pesquisa foi aprovada pelo Comitê de Ética em Pesquisa, sob o CAAE no 64424516.2.0000.5296. 


\section{ANÁLISE E DISCUSSÃO}

\subsection{A FORMAÇÃO DOS PROFESSORES}

Nas entrevistas, quando perguntado a respeito da existência de conteúdos relacionados a políticas educacionais na grade curricular de suas faculdades, os professores responderam denunciando a existência de um déficit nesse sentido em suas formações.

Professor 1: Sim, mas realmente muito pouco, a gente estudou muito pouco isso na universidade, mas estudamos, temos algumas disciplinas que contemplam políticas públicas.

Professor 4: Assim, eu não tenho nenhum conhecimento... nunca estudei o que é política pública na área educacional, nem há disciplinas na universidade pra isso.

Já em relação a formação continuada, percebeu-se uma enorme deficiência no que diz respeito ao investimento do poder público na capacitação do corpo docente. Quando perguntado aos professores se eles tinham acesso a qualquer tipo de capacitação sobre as políticas de ensino vigentes atualmente oferecidas pela gestão pública as respostas foram sempre negativas.

Professor 2: algumas coisas deveriam ser mais planejadas, mas aí vão empurrando, coloca e a gente tem que dá de conta daquilo [...] Não tem uma formação pra dizer: "olhe, vai ter", como é que vai ser feito, não, "a partir de hoje é assim, pá puf” [...] Aí a gente fica assim: Como, por que, né? E são vários pontos, principalmente na área de educação. Professor 3: 0 sistema [...] é informado pra coordenadora, a coordenadora passa pra a gente [...] como vai ser passado o conteúdo, se é prova, se é trabalho [...] o conteúdo fica a critério do professor.

Professor 4: Eu ensino aqui já há 5 anos, vai fazer agora em julho, e nenhum desses anos que eu estou aqui eu tive [...] nenhuma das escolas me ofereceram [...] nem que fosse uma conversa ou alguém da secretaria vir e mostrar o que é que a gente poderia fazer como alternativas, nada, não há.

Segundo Cabral Neto e Castro (2004, p. 101), a política do Banco Mundial considera a melhoria de qualidade como eixo da reforma educativa. No seu entendimento "essa qualidade estaria centrada nos "insumos" que intervêm na escolaridade", entretanto, apenas alguns desses "insumos" são priorizados. Considerando a ótica economicista do Banco Mundial, a formação dos professores vem sendo tratada de forma marginal, ambígua e inconsistente, não se constituindo, portanto, como prioridade.

De acordo com os mesmos autores, as diretrizes do campo formação deverão privilegiar a formação continuada em detrimento da formação inicial e a utilização da educação a distância, considerando a redução dos custos e o atendimento em massa dos professores. Entretanto, os referidos autores denunciam que a educação a distância não é uma política consistente, e exclui a maioria da população nos processos educativos. É articulada com as orientações dos organismos internacionais com características minimalistas, de estratégias neoliberais que reduz os custos e investimentos do Estado nas áreas sociais (CABRAL NETO; CASTRO, 2004).

Com os governos eximidos de tais responsabilidades não é de se estranhar que passe a ser dos alunos a culpa por suas dificuldades. Aumentando ainda mais a cultura de patologização de quem não consegue acompanhar um sistema educacional tão cheio de falhas (Viegas, 2015).

\subsection{A COMPREENSÃO DOS PROFESSORES A PARTIR DA PRÁTICA}

Levando em consideração que os professores não têm nenhum tipo de apoio no que tange o âmbito das políticas educacionais diretamente no contexto escolar - de acordo com os resultados obtidos através das respostas dadas anteriormente - cabe a eles aprender na prática o funcionamento delas. Dessa forma os professores se veem no lugar de executores, de agentes que servem apenas para colocar em prática os fins da política, sem ao menos conhecer os porquês daquela aplicação, fato que acaba comprometendo o rendimento e o trabalho do professor, influenciando diretamente o processo ensino-aprendizagem.

Através da fala dos professores identifica-se que eles têm pouco ou quase nenhum entendimento em se tratando da política Progressão Continuada, compreendendo-a apenas através das reverberações em seu trabalho como mostram os trechos das entrevistas a seguir acerca da pergunta " 0 que você sabe a respeito da Progressão Continuada?":

Professor 3: Sim! É tipo [...] é a chamada "dependência", né? Bom, a dependência é um sistema de ensino que ele é muito interessante e muito eficaz, mas é mal aplicado. [...]. Porque um aluno que... que ele vai pra progressão ele fica dependendo dessa disciplina só que ele não tem aula presencial. [...] Porque o correto 
seria ele ter a aula regular [...] do ano que ele tá fazendo e ele ter no contraturno aula presencial numa turma normal com... essa... essa série da progressão. Mas isso não acontece. É um... é um método de ensino é EAD.

Professor 4: Não, o que eu sei é relacionado... eu sei de modo geral, né, que é a progressão do aluno, né, tendo ficado retido em alguma disciplina, um ou até três disciplinas [...]. Então esse aluno passa para o ano seguinte ficando retido em alguma das disciplinas, né?

As políticas públicas impostas de forma autoritária deixam uma sequela na forma como o professor desenvolve criticamente sua prática e a forma como executa a produção do saber, tornando o processo extremamente desgastante e causador de sofrimento psíquico para alguns deles. Sem o discernimento de que são os próprios professores responsáveis pela execução dessa política, muito menos a que ela propõe, a política acaba, na perspectiva do professor, trazendo consequências tão graves quanto a evasão escolar e a reprovação; o desinteresse pelo aprender, a desmotivação familiar e a presença de crianças analfabetas em classes avançadas. Souza (2007, p. 3), analisando os dados do SAEB (Sistema Nacional de Avaliação da Educação Básica) revela que "menos de $5 \%$ dos estudantes da 4 a série estão adequadamente alfabetizados para a série, sendo que quase $19 \%$ são, provavelmente, analfabetos".

Professor 1: [...] isso acomoda muito o aluno, acomoda a família, porque sabe que vai passar de todo jeito [...] quando chega agora no quarto ano, você tem que lidar com várias situações [...] são situações extremas, que são todas muito complicadas, porque você tem vários níveis de aprendizagem no quarto ano. [...] porque o aluno, ele sabe que vai passar de todo jeito, ele sabe que não precisa ter nenhum tipo de esforço, sabe?

Professor 2: Alguns não conhecem nem todas a letras do alfabeto, então assim, isso é certo? Como é que eu vou dá de conta disso bem direitinho pra entregar pronto pro quarto ano? [...] porque faz quatro ou cinco anos que estou no terceiro ano, a cada ano vem aumentando o nível de crianças sem ler, eu não vou nem dizer analfabeto, eu tou dizendo sem ler mesmo[...] Eram 8, pulou pra 12, 16, ano passado eu tinha 18 que não lia. Então qual é a dificuldade que eu tou sentindo? Eu tou recebendo alunos nessa situação. E aí eu tenho que fazer o papel dos três anos [...] E aí eu vou conseguir? Cadê a vontade do aluno se sabe que ele vai pro quarto de todo jeito? É isso que eu quero enfatizar, focar nisso, como é que o aluno vai ter vontade, nem a família vai se preocupar se de todo jeito ele vai pro quarto?

A visão de que a Progressão Continuada retira do aluno a motivação do aprender, entra em conflito mais uma vez com a função da escola. Se retirar a reprovação torna o aluno e os familiares desmotivados, a motivação para estudar teria apenas como foco a não reprovação, isso tanto reduz o papel da escola na sociedade como influencia diretamente na prática do professor, pois a sua prática será baseada nessa perspectiva, tornando-o tão desmotivado quanto o aluno. Impor políticas públicas e/ou sociais, que influenciam a práxis do docente, mas que não tem sua participação nas formulações dessas políticas, também faz o professor questionar sobre a ausência de metas a serem atingidas, trazendo uma antiga visão de exclusão, que seria um dos mecanismos que a progressão propõe acabar ao ressignificar as concepções de ensino, aprendizagem e avaliação. Aqui depara-se, provavelmente, com uma discussão ideológica, causada pelo capitalismo.

Além do mais, consonante aos autores citados anteriormente, é relevante lembrar a situação vivenciada pelo Brasil, em que, mesmo tendo havido mudança de governo e de partido político com orientação ideológica diferente, a política educacional não se altera em sua essência. Continua, como no governo anterior, alinhada às orientações políticas desses organismos internacionais, já delineadas em um conjunto de planos e instrumentos normativos, ou seja, um conjunto de ideologias e diretrizes que deixam o professor e a sociedade desnorteados. De acordo com o mesmo autor, a orientação das ideias neoliberais se faz sentir claramente nessa perspectiva de modernização da gestão, uma vez que todas as relações são vistas como relações de mercado.

Seguindo essa lógica, a política educacional do Estado Brasileiro, visando a produtividade, propõe o redimensionamento do sistema do ensino, o qual está alinhado as diretrizes políticas das agências internacionais que financiam projetos educacionais para os países em desenvolvimento como o Brasil. "A descentralização, configurada no âmbito das diretrizes, se situa numa perspectiva de desconcentração, associada à uma perspectiva neoliberal traduzida na transferência das responsabilidades do Estado para a sociedade, como estratégia de redução dos gastos públicos e de suas responsabilidades" (CABRAL NETO, 2004, p. 62).

Dessa forma a família responsabiliza a escola, essa, por sua vez, responsabiliza a família, tornando-se um ciclo que se retroalimenta, agravando o processo de patologização, exclusão e culpabilização das crianças 
e alunos, conforme Viégas (2015). Essa demanda é a que chega para a psicologia em serviços de assistência, saúde e educação.

\section{CONSIDERAÇÕES FINAIS}

Nota-se então que mesmo passado tanto tempo sabendo da existência desse abandono do poder público às escolas, contando com professores, gestão e alunos, e mesmo recebendo críticas por todos esses anos o governo continua sem dar importância a tais fatos (VIÉGAS, 2015). A política de Progressão Continuada é apenas mais uma das tantas políticas educacionais que são implantadas de maneira autoritária e os agentes executores que serão os responsáveis por fazer todo o sistema funcionar nem ao menos sabem conceitos básicos relacionados a ela.

Cabe evidenciar que as reformas empreendidas no país, apesar de serem justificadas por razões de competitividade e de equidade, na prática, são essencialmente motivadas por questões de ordem financeira. Essas reformas em conjunto formam estratégias que reduzem os gastos, mas também os investimentos em educação, principalmente com o pessoal docente. "Assim, essas reformas provocam efeitos econômicos e educativos que, na maioria das vezes, não se traduzem na melhoria da qualidade e nem da equidade, pelo contrário, em muitos casos, essa situação é agravada pelos cortes dos investimentos" (CABRAL NETO; CASTRO, 2004, p. 102). Ou seja, uma "hibridização" de ideias, diretrizes e normas, que mascaram um desejo de eficiência e produtividade do sistema de ensino, pautando grande reformas educacionais, que efetivamente se tornam contrarreformas.

Por isso, faz-se relevante a criação de espaços para que o professor reformule conceitos através do pensamento crítico sobre sua prática. Percebe-se "que é possível e viável desenvolver estratégias de capacitação que levem os docentes a assumir um papel ativo, descrevendo a sua prática, analisando-a e sugerindo alternativas para reconstruí-la" (ANDRÉ, 2015, p. 95). Visto isso não cabe aqui defender ou criticar a política Progressão Continuada, mas fazer uma crítica ao olhar sobre ela, buscando a abertura da visão das autoridades e de toda a população, para que a escola não perca seu sentido, podendo cumprir com seu objetivo, mudando seu sentindo inicial de interesses econômicos e mecanismo de controle ideológico, para ter, efetivamente, condições de colaborar na formação de sujeitos críticos e transformadores, possibilitando para seus alunos a vivência de experiências significativas que contribuam com a formação de uma sociedade mais justa e humana.

\section{REFERÊNCIAS}

[1] André, M. E. D. A. de. Pesquisação e a formação de professores em serviço. In: André, M. E. D. A. de. Etnografia da Prática Escolar. Campinas: Papirus, 2015. p. 89-100.

[2] Azanha, J. M. P. Planos e políticas da educação no Brasil: Alguns pontos para reflexão. 5. ed. São Paulo: Cad. Hist. Filos. Educ., 2004.

[3] Bisconsini, C. R.; Flores, P. P.; Oliveira, A. A. B. de. Formação inicial para a docência: o estágio curricular supervisionado na visão de seus coordenadores. J. Phys. Educ., Maringá, v. 27, n. 2702, p.1-13, 2016.

[4] Bogdan, R. C.; Biklen, S. K. Análise de dados. In: Bogdan, R. C.; Biklen, S. K. Investigação qualitativa em Educação. Porto Editora, 1994.

[5] Brasil. Lei no 11.274, de 6 de fevereiro de 2006. Altera A Redação dos Arts. 29, 30, 32 e 87 da Lei no 9.394, de 20 de Dezembro de 1996, Que Estabelece As Diretrizes e Bases da Educação Nacional, Dispondo Sobre A Duração de 9 (nove) Anos Para 0 Ensino Fundamental, Com Matrícula Obrigatória A Partir dos 6 (seis) Anos de Idade. Brasília, Disponível em: <http://www.planalto.gov.br/ccivil_03/_Ato20042006/2006/Lei/L11274.htm\#art3>. Acesso em: 7 jun. 2017.

[6] Brasil. Ministério da Educação e Cultura. Ensino Fundamental de nove anos: passo a passo do processo de implantação. 2 ed. Brasília, DF: Mec/SEB, 2009.

[7] Cabral Neto, A.; Castro, A. M. D. A. A formação de professor no contexto das reformas educacionais. In: Yamamoto, O. H.; Cabral Neto, A. O Psicólogo e a escola: uma introdução ao estudo da psicologia escolar. Natal: Edufrn, 2004. p. 95-135.

[8] Cabral Neto, A. Política educacional brasileira: novas formas de gestão. In: Yamamoto, O. H.; Cabral Neto, A. 0 Psicólogo e a escola: uma introdução ao estudo da psicologia escolar. Natal: Edufrn, 2004. p. 35-68. 
[9] Leite, S. A. da S. A construção da escola pública democrática: algumas reflexões sobre a política educacional. In: ORG., Conselho Regional de Psicologia de São Paulo. Psicologia e Educação: contribuições para a atuação profissional. São Paulo: Conselho Regional de Psicologia de São Paulo Org., 2007. p. 17-26.

[10] Mozzato, A. R.; Grzybovski, D. Análise de conteúdo como técnica de análise de dados qualitativos no campo da administração: potencial e desafios (Documentos e Debates). Passo Fundo: Revista de Administração Contemporânea, 2011. 731-747 p. Recuperado de http://www.scielo.br/pdf/rac/v15n4/a10v15n4.pdf. doi: 10.1590/S141565552011000400010.

[11] Silveira, D. T.; Córdova, F. P. A pesquisa científica. In: GERHARDT, T. E.; SILVEIRA, D. T. Métodos de pesquisa. Rio Grande do Sul: Ufrgs Editora, 2009. Cap. 2. p. 31-42. Disponível em: <http://www.ufrgs.br/cursopgdr/downloadsSerie/derad005.pdf>. Acesso em: 15 out. 2016.

[12] Souza, B. de P. Funcionamentos escolares e a produção do fracasso escolar e sofrimento. In: SOUZA, B. de P. (org.). Orientação à queixa escolar. São Paulo: Casa do Psicólogo, 2007.

[13] Viégas, L. de S. Progressão continuada e suas repercussões na escola pública paulista: concepções de educadores. São Paulo, 2002. 250 p. Dissertação (Mestrado). Instituto de Psicologia, Universidade de São Paulo.

[14] Viégas, L. de S. Progressão Continuada em uma perspectiva histórica. Rev. Br. Est. Ped., Brasília, v. 90, n. 225, p.489-510, maio 2009.

[15] Viégas, L. de S. Progressão Continuada e Patologização da Educação: um debate necessário. Psicol. Esc. e Educ., [s.l.], v. 19, n. 1, p.153-161, abr. 2015. FapUNIFESP (SciELO). http://dx.doi.org/10.1590/2175$3539 / 2015 / 0191815$. 


\section{Capítulo 13}

Modelo de reforma educacional Made In USA: os riscos da importação para a política educacional Brasileira

\section{Luciana Dantas Sarmento da Silva \\ Matilde Gonçalves Mendes}

Resumo: Este artigo discute as reformas educacionais baseadas no modelo de mercado iniciadas nos Estados Unidos e importadas pelo Brasil. A reforma iniciada na década de 80 tomou fôlego e trouxe mudanças que, em certos aspectos, tiveram um efeito contrário ao que se buscava. A criação de escolas por concessão, o accoutability, o estímulo a competição, a premiação ou punição baseada em índices quantitativos, produziram o enfraquecimento da escola pública e a desvalorização docente. Este modelo tem inspirado reformas educacionais no Brasil, as ações claramente gerencialistas são apresentadas como solução para os problemas da educação pública. Percebe-se assim, que as reformas vêm sendo implantadas baseadas em uma definição equivocada de qualidade. Dessa forma, objetiva-se aqui mostrar que a importação do modelo americano sem reflexão e adaptações pode desviar o foco da qualidade para a busca desenfreada por resultados.

Palavras-chave: reformas educacionais, modelo de mercado, accoutability. 


\section{INTRODUÇÃO}

0 presente artigo pretende discutir as reformas educacionais baseadas no modelo gerencial de mercado iniciadas nos Estados Unidos e importadas pelo Brasil. 0 objetivo é mostrar como essas medidas de combate ao fracasso escolar e fortalecimento da educação pública, em alguns aspectos surtiram um efeito contrário na educação americana, e que por esta razão não podem ser meramente copiadas sem que se haja reflexão e críticas necessárias.

Pressupostos semelhantes aos dos reformadores americanos vêm conduzindo mudanças em vários sistemas educacionais no Brasil, atraindo gestores públicos e a opinião popular com a promessa de solução rápida e eficaz para os problemas educacionais. 0 terreno tornou-se fértil para a introdução dessas mudanças que atribuem à lógica privada a capacidade de elevar os índices de desenvolvimento e qualidade da educação, embora estes resultados não tenham sido comprovados pela experiência norteamericana (OLIVEIRA \& MENEGÃO, 2012).

\section{A REFORMA AMERICANA: O MODELO DE MERCADO COMO SOLUÇÃO PARA A EDUCAÇÃO}

Nos anos de 1983, o relatório A Nation at Risk mostrou a desvantagem dos Estados Unidos diante do resto do mundo em termos de sucesso escolar, com grande parcela de seus jovens sendo enquadrados como analfabetos funcionais. Deste relatório tiveram início as discussões e principalmente a busca por mudanças.

As discussões que inicialmente tratavam do currículo escolar, foram desviadas. Os questionamentos deixaram de ser sobre o que está sendo ensinado, como se está aprendendo, para "quem são os responsáveis pelos resultados ruins". Dessa forma, a reforma educacional americana que, primeiramente, inclinou-se para uma mudança curricular, logo redirecionou-se para mudanças baseadas no modelo gerencial de mercado.

Para Oliveira e Menegão (2012), as atuais reformas estão restringidas a responsabilização e desviadas do foco de o que fazer para melhorar a escola pública. Ao invés de se dedicar a questão, entrega-se a escola pública aos cuidados e administração da iniciativa privada, uma vez que se julga a administração pública ineficaz. As escolas por concessão criadas nos anos 90 são a maior expressão disso.

As escolas por concessão ou escolas de charter, são estabelecimentos públicos administrados pela iniciativa privada, elas se proliferaram, e passaram a servir como referência de qualidade. Tais escolas são abertas em áreas consideradas de risco e que geralmente apresentam os piores resultados educacionais, numa tentativa de mostrar que os números ruins alcançados pela escola pública não estavam relacionados ao contexto social, mas sim, a má administração do Estado, assim como à incapacidade do corpo docente. No entanto, desconsidera-se que as escolas de charter excluem estudantes de baixo desempenho e são beneficiadas não somente por recursos públicos, mas principalmente pelo financiamento do que chamamos de Terceira Via.

A Terceira Via "é uma tentativa de transcender tanto a social democracia do velho estilo, quanto o Neoliberalismo" (GIDDENS, 2001, p. 36 apud PERONI, 2008, p. 04). Para a Terceira Via faz-se necessário, não o encolhimento ou a expansão do Estado, mas sim, a sua reconstrução. Apregoando que a sociedade civil modernizada, empreendedora e bem-sucedida deve ser incentivada pelo Estado a assumir a responsabilidade pelas políticas sociais, políticas estas que foram historicamente conquistadas pela sociedade civil organizada (PERONI, 2008).

Ainda de acordo com Peroni (2008) o terceiro setor, caracterizado como o público não-estatal acaba assumindo atividades que seriam do Estado, assim como também adquire poder econômico e político quanto ao repasse e prestação de contas dos recursos financeiros sem a intermediação do Estado, mas diretamente às agências internacionais

A questão social é assim modificada com o repasse da responsabilidade do Estado para o indivíduo, como também, pelo fato de que as políticas sociais passam a ser focalizadas, perdendo seu princípio universalista, e ainda com a descentralização administrativa, as políticas tendem a ser precarizadas, uma vez que são transferidas competências sem os recursos correspondentes a sua execução.

Livres das regulamentações do Estado, os reformadores educacionais acreditam que as escolas poderão atingir melhores resultados. Abrir as escolas para a administração privada produziria uma saudável variedade no sistema educativo. Dessa forma, as famílias e estudantes poderiam escolher livremente 
escolas de melhor desempenho. Desregulamentação, competição e escolha, estes três elementos definem bem a proposta das escolas de charter (OLIVEIRA \& MENEGÃO, 2012).

As iniciativas baseadas no modelo de mercado tornaram-se ainda mais efetivas a partir de 2002, quando no governo Bush foi aprovada uma nova legislação federal para a educação, a lei No Child Left Behind (NCLB). A responsabilização e os testes padronizados tornaram-se ainda mais importantes, caracterizando-se como as principais finalidades da reforma educativa.

Os resultados dos testes passaram a definir os destinos de escolas e de profissionais. Por esta razão, muitas instituições passaram a elaborar seus currículos de acordo com as exigências dos testes. Obter êxitos e maiores escores tornava-se uma questão de sobrevivência. Resultados ruins significariam fechamento de escolas e demissões de profissionais.

O documentário do diretor Davis Guggenheim "Esperando o Super-homem", lançado no ano de 2010 expõe problemas enfrentados pelo sistema educacional norte americano, através da história de cinco crianças que buscam fugir das estatísticas do fracasso escolar. Com um apelo dramático, o documentário é uma defesa à reforma educacional baseada no modelo de mercado.

No documentário, a fala do diretor Davis Guggenheim chama a atenção, ao referir-se a um documentário anterior também feito por ele em 1999, no qual acompanhou o dia a dia de professores americanos de escolas públicas, ele diz: "professores personificavam a esperança e carregavam a promessa de que um dia a escola pública poderia dar certo". Nos dias atuais, o diretor afirma matricular seus filhos em escolas privada por ter "medo da escola pública".

Percebe-se aqui, que Guggenheim atribui aos professores a responsabilidade pelo bom desenvolvimento da educação, como se estes fossem sozinhos capazes de fazer o sistema educativo como um todo evoluir. Se mais à frente o mesmo afirma ter medo da escola pública, podemos concluir que os professores não alcançaram tais metas.

Ainda no documentário, pode-se destacar a fala do educador Geoffrey Canada, presidente da Harlem Children Zone, que diz: "não conseguíamos encontrar os arquitetos do por que isso estava tão ruim". Mais uma vez busca-se a responsabilização ou neste caso, a culpabilização pelos resultados negativos. Unindo as falas do diretor e do educador pode-se questionar: tais arquitetos seriam os professores?

o documentário mostra o sindicato docente como um dos grandes empecilhos do sistema educacional americano, uma vez que defende vorazmente o direito de estabilidade da categoria, assim como se opõe ao sistema meritocrático imposto, que por meio de testes definem quais escolas e profissionais devem ser punidos ou recompensados. Em uma reforma baseada nos moldes do mercado, profissionais que não alcançam as metas estabelecidas devem ser demitidos, do contrário, significam um entrave para o desenvolvimento.

Em Nova York, por exemplo, professores que estão sofrendo algum tipo de processo administrativo, são indisciplinados quanto a pontualidade e assiduidade, ou não apresentaram resultados satisfatórios, conseguem manter seu vínculo empregatício garantido por seu direito a estabilidade, contudo são afastados das salas de aula, cumprindo sua carga horária junto aos demais profissionais que se encontram nas mesmas condições nos chamados rubber rooms ou quartos emborrachados, numa referência aos quartos de hospitais psiquiátricos. Neles professores não têm computadores ou livros, não recebem nenhum tipo de capacitação ou incentivo para que retomem suas funções. Não fazem nada. São pagos para serem uma pedra fora do caminho. Não são demitidos, mas as condições que lhe são impostas acabam por resultar em demissão voluntária.

Seguindo a lógica defendida pelos reformadores educacionais e propagandeada pelo documentário "Esperando o Super-homem", profissionais competentes seriam capazes de resolver o problema da disparidade de desempenho entre estudantes de diferentes grupos sociais.

Neste sentido, Ball (2005) afirma que o profissionalismo está sendo desalojado. Como uma categoria préformada, ele baseia-se em uma relação entre o profissional e o seu trabalho, em uma reflexão moral sobre a tomada "correta" de decisões. Para o autor, o termo profissionalismo baseia-se em ambiguidade e pluralismo, pois estes desenvolvem a responsabilidade moral pela ação. Eliminada a reflexão moral e o diálogo, o profissionalismo deixa de existir. Nos dias atuais, esse termo assume um significante semelhante, mas um novo significado. O "novo profissionalismo", "reprofissionalismo", "pósprofissionalismo" ou profissionalismo pós-moderno" diferencia-se completamente daquilo que podia ser compreendido como profissionalismo. 
Ainda de acordo com o autor, os principais pontos de diferença entre o profissionalismo e o pósprofissionalismo são a redução do segundo à obediência de regras e a confinação do profissionalismo a uma forma de desempenho, que considera somente a satisfação de julgamentos fixos e impostos externamente. "A eficácia só existe quando é medida e demonstrada, e as circunstâncias locais só existem como "desculpa" inaceitável para falhas na execução ou adaptação" (BALL, 2005, p. 543).

As reformas educacionais realizada nos Estados Unidos vêm sofrendo críticas ferrenhas, como as de Diane Ravitch, pesquisadora-doutora da Universidade de Nova Iorque. Em 1991, Ravitch aceitou o convite do então secretário Lamar Alexander para ser sua conselheira e secretária-adjunta no Departamento de Educação dos Estados Unidos. Também esteve envolvida como conselheira nos governos Bill Clinton e George W. Bush e participou ativamente de movimentos pelas referências curriculares, responsabilização e escolha escolar. Ao perceber os efeitos negativos das reformas, passou a militar pela causa da escola pública, promovendo uma verdadeira campanha contra as reformas educacionais baseadas na lógica empresarial. Em 2010, publicou o livro Vida e Morte do Grande Sistema Escolar Americano, apresentando a evolução das reformas nas últimas décadas, criticando seus pressupostos ideológicos e denunciando seus resultados, que contribuíram para agravar a crise da educação pública americana (OLIVEIRA \& MENEGÃO, 2012).

Ainda assim, o homem de ferro, vestindo azul e vermelho, atravessa o continente de um hemisfério a outro com uma velocidade extraordinária. 0 modelo americano chega ao Brasil também com a promessa de nos "salvar" do fracasso escolar, esse grande vilão.

\section{A INFLUÊNCIA DAS REFORMAS AMERICANAS NA EDUCAÇÃO BRASILEIRA}

No Brasil, o Plano Diretor da Reforma do Estado de 1995 redefine o papel do Estado que deixa de ser o responsável direto pelo desenvolvimento econômico e social para agir enquanto promotor e regulador desse desenvolvimento. Entre as estratégias do plano estão a privatização, a publicização e a terceirização. 0 Estado continuaria financiando os serviços sociais, mas seu controle ideológico e político passaria para organizações públicas não-estatais (PERONI, 2008).

Para Peroni (2003, p. 15-16) "os projetos de política educacional apontavam para um processo de centralização por parte do governo federal, controle ideológico da educação, através dos parâmetros curriculares e da avaliação institucional e para o processo de descentralização de recursos, inclusive desobrigando a União do financiamento da educação básica".

De acordo com Hypolito (2010), as políticas educacionais brasileiras vêm sendo delineadas e implementadas desde o final dos anos de 1980 como políticas de caráter neoliberal, que passaram a ser cotidianas não somente na educação, como também na cultura, na política e principalmente na economia. Para o autor, embora adote um discurso descentralizador, o Estado intervém como agente regulador das políticas educativas de modo enfático e centralizado. As ações claramente gerencialistas são apresentadas como solução para os problemas da educação pública, articuladas por meio de pressupostos da eficiência, dos resultados, da avaliação e da competência.

A partir dos anos 90, as reformas educacionais brasileiras tiveram como foco a gestão, promovendo "por meio da descentralização administrativa, financeira e pedagógica a ampliação do acesso à educação básica no país a partir de uma lógica racional, que tinha como paradigma os princípios da economia privada" (OLIVEIRA, 2011, p.326)

No governo do presidente Fernando Henrique Cardoso, a educação brasileira vivenciava um processo de fragmentação da gestão, com um excesso de programas sociais e educativos que almejavam "atender a públicos focalizados, transparecendo grande dispersão de políticas temporárias que se afirmavam mais como políticas de governo que de Estado" (OLIVEIRA, 2011, p. 327). Sobre política de governo, e políticas de Estado Oliveira esclarece:

[...] políticas de governo são aquelas que o Executivo decide num processo elementar de formulação e implementação de determinadas medidas e programas, visando responder às demandas da agenda política interna, ainda que envolvam escolhas complexas. Já as políticas de Estado são aquelas que envolvem mais de uma agência do Estado, passando em geral pelo Parlamento ou por instâncias diversas de discussão, resultando em mudanças de outras normas ou disposições preexistentes, com incidência em setores mais amplos da sociedade (2011, p. 329). 
Oliveira (2001) assinala que o conjunto de reformas educacionais implantadas pelo governo FHC foram: à redefinição dos currículos por meio dos Parâmetros Curriculares Nacionais (PCN); à avaliação pelo incremento ao Sistema Nacional de Avaliação da Educação Básica (SAEB) e depois o Exame Nacional de Cursos (ENC); à gestão e ao seu financiamento, melhor exemplificado pela criação do Fundo de Manutenção e Desenvolvimento do Ensino Fundamental e de Valorização do Magistério (FUNDEF). Principalmente na educação básica, as mudanças realizadas redefiniram sua estrutura. As mudanças na legislação educacional brasileira consumaram essa nova configuração, tendo como manifestação maior a Lei de Diretrizes e Bases da Educação Nacional (LDBN) n. 9.394/96.

Ao final do governo, a educação nacional encontrava-se (des)sistematizada, em outras palavras, fragmentada, segmentada, flexível e dispersa, dificultando o estabelecimento de bases de cooperação, integração e coesão entre os entes federados e ainda mais entre os indivíduos da sociedade (OLIVEIRA, 2011).

Nos primeiros anos que se sucederam, mesmo com a mudança do governo FHC para o governo Lula, observou-se a mesma fragmentação e descontinuidade da década anterior. Pode-se considerar que a primeira grande iniciativa do novo governo foi o Plano de Desenvolvimento da Educação (PDE), que apelou para a responsabilização e mobilização de todos os agentes públicos envolvidos na educação, repartindo as competências e responsabilidades para elevar os indicadores nacionais, mas principalmente no que diz respeito a educação básica (OLIVEIRA, 2011).

Também foi criado o Plano de Ações Articuladas (PAR), que busca a elevação do Índice de Desenvolvimento da Educação Básica - IDEB. O IDEB nasceu em 2007, e passou a ser a principal referência do governo para medir a qualidade da educação.

Outra iniciativa importante foi a aprovação do Piso Nacional de Salários para professores da educação básica, assim como a instituição do Fundo de Manutenção e Desenvolvimento da Educação Básica FUNDEB. Contudo, estes ainda não foram o suficiente para tornar a carreira docente atrativa.

Na busca pela articulação do Sistema Nacional de Educação no Brasil, foi votado, já no governo FHC, o Plano Nacional de Educação - PNE. 0 documento elaborado com vigência de 2001 a 2010, não surtiu o efeito esperado, pois sofreu diversos vetos pelo então presidente, o que acabou por comprometer suas metas e objetivos. Assim como o PNE 2011-2020, que passados quatro anos de sua elaboração ainda estava sendo submetido à aprovação do senado federal. Às vésperas da Conferência Nacional de Educação (CONAE) - 2014, que serviria para avaliar o desenvolvimento do PNE 2011-2020 e encaminhar as propostas para próximo PNE, o plano encontrava-se parado, porém, ainda teve aprovação naquele mesmo ano, modificando a data de vigência do PNE 2014 - 2024.

Toda política pública é elaborada e colocada em ação a partir de intencionalidades, objetivos, público alvo, mecanismos de financiamento e implementação. Nesse sentido, sua elaboração deveria essencialmente primar pelo debate público, sobretudo quando os objetivos deverão focar a sociedade e não os agentes privados. As mudanças no cenário educacional deveriam concatenar com o papel da educação que se traduz pelo desenvolvimento contínuo da consciência socialista, que é sem dúvida um componente crucial para o grande processo transformador.

Políticas de governo vêm caminhando de modo que, se faz necessário, manter-se em constante vigilância para ser capaz de compreender e acompanhar as movimentações da política nacional e a interferência desta no campo educacional. Uma crítica pertinente diante deste cenário, de acordo com o autor, foi o governo de Michel Temer que em meio ao que podemos categorizar como um golpe nas esferas política, midiática e jurídica, e sua instituição como governo provisório. Assim, a política deve ser entendida como processo mais do que produto.

No entanto, o que se pode apontar é que os movimentos estão se dando de modo contrário, configurandose em '(anti)reformas', pois a destituição do debate público mostra com clareza a forma primária e arbitrária da condução das chamadas reformas educacionais. Toma-se como exemplo a proposição da BNCC, sobretudo no Ensino Médio, modelo pronto e diagramado para todas as necessidades educacionais do país, bem como, a dissolução do FNE (Fórum Nacional de Educação), negando a dialogicidade dos agentes sociais.

A (anti)reforma curricular e a (anti)reforma do Ensino Médio em andamento, por meio da Lei № 13.415/2017 (BRASIL, 2017) nos trará consequências de uma homogeneização por meio de um currículo único em nível nacional. Nesse sentido, destacamos algumas decorrências que serão incorporadas como 
resultado desse processo antirreformista que se instala no país (MOREIRA, 2018, p. 208).

De acordo com o autor, acredita-se que estas reformas acarretarão perdas importantes com relação ao legado multiétnico que a sociedade brasileira vinha construindo, chega a considerar um apagamento cultural de legados importantes mediante adesão acrítica a culturas neoconservadoras e hegemônicas, o que implicará em menos conteúdo para a formação humanística e cidadã.

Para Hypolito (2010), o que deve ser destacado nessas políticas é a centralidade nos aspectos econômicos em detrimento dos aspectos políticos e sociais, como o deslocamento da educação para a esfera do econômico e dos modelos gerenciais difundidos pelo mercado. 0 que deveria ser pressuposto de qualidade para a educação pública, garantida pelo Estado, passa a ser considerado como deficiência de seus usuários. Complementando com Oliveira e Menegão:

[...] a lógica de mercado não é apropriada para prover educação pública. A competição por clientes, o atendimento ao público de forma diferenciada e a oscilação de oferta fazem parte da esfera do mercado, mas perdem o sentido quando são transpostas para a esfera pública, encarregada de prover direitos sociais que devem ser garantidos a todos, independente do poder político e da posição na esfera produtiva. As esferas pública e privada podem coexistir, mas possuem objetivos de natureza distinta e devem ser regidas de acordo com a lógica coerente com seus objetivos (2012, p.657)

O modelo gerencialista é também marcado pela política de responsabilização ou accountability, sustentada pelo tripé avaliação, prestação de contas e responsabilização. Esta vem sendo discutida e combatida pela forma negativa que tem assumido, uma vez que adquiriu um fim em si mesma. Avaliar, mostrar resultados e responsabilizar punindo ou premiando tornaram-se a mola mestra das reformas, sendo apontada como capaz de solucionar os problemas de qualidade da educação pública. Nesse pacote, acompanha a desprofissionalização do professor nos sistemas de ensino e desse modo, surgem as contratações de professores não qualificados, ou pode-se chamar aqueles de notório saber, sem carreira e com diversas facetas, talvez um movimento que pode ser chamado de "uberização docente" (MOREIRA, 2018, p. 204).

Antes de tudo, cabe aqui refletir sobre qual concepção de qualidade tem motivado as reformas, o que se espera alcançar. Conhecer as finalidades possibilita compreender a escolha dos meios.

Entende-se que o conceito de qualidade não é único. Neves (2013) coloca que no debate educacional dos anos 90, duas posições antagônicas eram discutidas: a concepção de qualidade total e a concepção de qualidade social. A primeira orientava-se para a preparação da mão de obra adaptada às exigências do mercado com vistas no desenvolvimento econômico e social. A segunda, objetivava a formação humana para a transformação das relações sociais.

Souza (2013) afirma que a definição e a busca pela qualidade é uma questão de democracia, não pode ser absoluto, rígido, aplicado de maneira universal sem que se distingua as diferentes realidades sócioeducacionais. É um equívoco limitar a definição de qualidade à dimensão quantitativa dos resultados estatísticos, que tem sido destacado e almejado por programas e ações da atual política educacional. Segundo o autor, a qualidade deve ser buscada, mas permanentemente combinada às ações que envolvam a superação real das condições nas quais se realiza o trabalho docente e o processo de ensinoaprendizagem.

Percebe-se assim, que as reformas vêm sendo implantadas baseadas em uma definição equivocada de qualidade. Estatísticas podem ser facilmente forjadas ou tendenciadas, principalmente quando os resultados positivos são cobrados a todo custo. Por uma autodefesa, profissionais e escolas direcionam suas atividades e limitam seus currículos para atender aos requisitos avaliados nos testes.

A maneira como foram implantadas as reformas, principalmente nos Estados Unidos, o impacto negativo que estas exercem por meio dos testes e punições, contribuem e alimentam uma representação social negativa acerca da temática accoutability. Se pensarmos isoladamente sobre avaliação, prestação de contas e responsabilização, perceberemos que são etapas necessárias a qualquer projeto. No entanto, o que tem ocorrido é uma verdadeira corrida por resultados estatísticos e culpabilização de indivíduos por metas não alcançadas. Reavaliar a compreensão atribuída ao tripé de sustentação do accountability faz enorme diferença. Tais significantes - avaliação, prestação de contas e responsabilização - adquirem diferentes significados de acordo com os interesses de quem os executa. 
Afonso (2012) nos coloca uma concepção alternativa de accountability, embasado em Stobart (2010), o autor propõe um "accountability inteligente". Este corresponde a "uma forma de prestação de contas e de responsabilização fundamentada em valores, promotora de confiança nos professores e nas escolas, mais construtiva do que a dos modelos atuais" (AFONSO, 2012, p. 477).

No que diz respeito a prestação de contas, de acordo com Afonso (2012) é importante destacar duas das suas componentes - a informação e a justificação. Informar o que foi ou não alcançado, além de ser uma das etapas do processo de alcance metas, é também um direito da população. Assim como justificar as iniciativas tomadas, o dinheiro gasto e o que não foi ou não pôde ser cumprido.

Sobre a responsabilização, é difícil não atribuir a ela a conotação negativa de culpa, o que acaba por envolver também a própria noção accountability, dificultando que se pense de maneira mais crítica em formas alternativas do mesmo. Na educação deve-se considerar que o processo educativo é coletivo, não se faz por um único indivíduo (AFONSO, 2012). Ao que se refere a educação pública principalmente, o processo se dá entre Estado, escola e família, a responsabilidade é de todos, portanto a "culpa" não deve ser individualizada, salvo casos que envolvam má administração, desvio de verbas ou negligência, por exemplo.

No Brasil, em dezembro de 2013, o deputado Raul Henry relator da Comissão da Lei de Responsabilidade Educacional apresentou na Câmara dos Deputados o esboço da proposta inicial do Projeto de Lei no 7420, de 2006, da Sra. Professora Raquel Teixeira, que "dispõe sobre a qualidade da educação básica e a responsabilidade dos gestores públicos na sua promoção". Nele constam quatro princípios: o estabelecimento de um padrão mínimo de qualidade para todas as escolas do país; o financiamento suplementar da União; a responsabilização pelas metas do Plano Nacional de Educação (PNE) e a proibição do retrocesso social. No ano de 2017 a proposta foi aprovada pela comissão especial da Câmara que examinou o assunto.

Este último ponto do projeto merece destaque por ser mais polêmico, uma vez que coloca que nenhum governante poderá ao final de seu mandato apresentar uma Índice de Desenvolvimento da Educação Básica - IDEB mais baixo que o de seu antecessor, estando sujeito a pena de inelegibilidade por quatro anos, se constatado o retrocesso. Caso o gestor consiga comprovar motivos de força maior, terá a chance de se justificar.

Nesse sentido, o Brasil pode estar reproduzindo os mesmos equívocos cometidos pelas reformas educacionais americanas. Esse tipo de punição aos gestores públicos, atrelada aos índices educacionais, pode incorrer num resultado oposto ao esperado. Dentre as hipóteses, um dos possíveis resultados dessa lei é o de que, ao sentirem-se coagidos, os gestores passem a buscar os resultados positivos a todo custo, ainda que para isso precisem driblar as normas e mascarar os resultados.

Ainda que se pretenda garantir o crescimento educacional, medidas deste tipo correm o risco de promover uma corrida atrás do resultado pelo resultado, na qual a principal finalidade será a autopreservação e não garantia do direito a educação pública e de qualidade.

\section{CONSIDERAÇÕES}

Perceber onde estamos e para onde nos leva o que estamos fazendo (SILVA E SOUZA, 2009), estes são os principais pontos a serem refletidos antes de qualquer reforma educativa. A forma como o modelo gerencialista tem sido seguido pela educação brasileira pode nos empurrar para a competição e autopreservação. Escolas vão competir pelos melhores resultados em busca do bônus salarial, gestores e demais profissionais da educação buscarão aumentar os índices de desenvolvimento e apresentar melhores resultados para garantir seu direito a candidatura e recompensa salarial, escanteando a qualidade da educação para segundo plano.

Avaliação, prestação de contas e responsabilização são necessárias sim, mesmo porque, tais elementos fazem parte da própria democracia. No entanto, necessitam ser pensadas em função da qualidade da educação e em trabalho conjunto, não de cima para baixo ou objetivando somente - repetindo a fala de Geoffrey Canada - "encontrar os arquitetos" do porquê dos resultados.

Ainda que se busque a inspiração em modelos exteriores, deve-se considerar as peculiaridades locais, principalmente em um país de extensão continental como o Brasil e de realidades tão desiguais. Não é possível concordar que o estímulo a competição entre desiguais, por meio da punição ou recompensa, seja designada como mérito. Acreditar que a solução para melhorar a aprendizagem dos educandos encontrase em ampliar o tempo que passam em escolas sem estrutura para receber os mesmos em dois turnos e 
com profissionais sem formação, também não possível. Apresentar programas que trazem receitas a serem seguidas à risca por professores, desconsiderando sua autonomia, sua experiência e formação, não pode contribuir para a qualidade da educação pública, mas sim para a desqualificação do docente. Assim, cabe mais uma vez aqui a reflexão: para onde nos leva o que estamos fazendo?

\section{REFERÊNCIAS}

[1] Afonso, Almerindo Janela. Para uma Conceitualização Alternativa de Accoutability em Educação. Rev. Educação e Sociedade. Dossiê: Políticas Públicas de Responsabilização na Educação. Campinas, v. 33, n. 119, p. 647660, abr.-jun. 2012. Disponível em <http://www.cedes.unicamp.br> . Data de acesso 29/12/2013.

[2] Ball, Sthepe n. Profissionalismo, gerencialismo e performatividade. Caderno de Pesquisa, São Paulo, v. 35, n. 126, 2005. Disponível em: <http://www.scielo.br. Acesso em 10-01-2014.

[3] Hypolito, Àlvaro Moreira. Políticas Curriculares, Estado e Regulação. Rev. Educação e Sociedade. Educação, Estado e regulação. Campinas, SP/CEDES, n. 113, 2010. Disponível em: < http://www.scielo.br >Acesso em 07-102013.

[4] Moreira, Jane Alves da Silva. Reformas educacionais e políticas curriculares para a educação básica: prenúncios e evidências para uma resistência ativa. Germinal: Marxismo e Educação em Debate, Salvador, v. 10, n. 2, p. 199-213, Ago. 2018

[5] Neves, Lúcia Maria Wanderley. Plano Nacional de Educação (PNE): alguns pontos para discussão. In Novo Plano Nacional de Educação (PNE): debates e tensões. Organizadoras Andréia Ferreira da Silva, Melânia Mendonça Rodrigues. - 1. ed. - Campina Grande: EDUFCG, 2013. 21-54 p.

[6] Oliveira, Dalila Andrade. Das políticas de governo à política de Estado: Reflexões sobre a atual agenda Educacional brasileira. Educação e Sociedade; Campinas, V. 32, n. 115, p. 323 - 337, abr - junh . 2011. Disponível em < http // cedes. Unicamp.br>

[7] Oliveira, Sara Badra de \& Menegão, Rita de Cássia Silva Godói. Vida e Morte do Grande Sistema Escolar Americano: como os testes padronizados e modelo de mercado ameaçam a educação. Rev. Educação e Sociedade. Dossiê: Políticas Públicas de Responsabilização na Educação. Campinas, v. 33, n. 119, p. 647-660, abr.-jun. 2012. Disponível em <http://www.cedes.unicamp.br> Data de acesso 29/08/2013.

[8] Peroni, Vera Maria Vidal. Redefinições no papel do Estado: parcerias público/privado e a gestão da educação. Congresso Ibero-Luso-Brasileiro de Política e Administração na Educação. 2010. Disponível em: <http://www.anpae.org.br/iberolusobrasileiro2010/cdrom/123.pdf.>. Acesso em: 01-10-2013.

[9] Silva, Maria Vieira \& Souza, Silvana Aparecida de. Educação e Responsabilidade Empresarial: "novas" modalidades de atuação da esfera privada na oferta educacional . Educação e Sociedade. Interface entre o público e o privado para a oferta educacional: desafios contemporâneos, S.P., CEDES, n. 108, 2009

[10] Souza, Antônio Lisboa Leitão. O Novo PNE: mais do mesmo na garantia do direito à educação. In Novo Plano Nacional de Educação (PNE): debates e tensões. Organizadoras Andréia Ferreira da Silva, Melânia Mendonça Rodrigues. - 1. ed. - Campina Grande: Edufcg, 2013.107-125 p. 


\title{
Capítulo 14
}

\section{A educação brasileira no meio rural: Fase desenvolvimentista- 1930 a 1990}

\author{
Airton Carlos Batistela \\ Mariza Rotta \\ Everton MarcosBatistela \\ Mara Cristina Fortuna da Silva
}

Resumo: A articulação das políticas públicas de um país com características desenvolvimentista traz a capacidade de organizar, estruturar e sistematizar suas finalidades de acordo com políticas necessárias para se atingir os fins desenvolvimentistas do Brasil. A educação apresentou-se neste período como estratégica para a execução dos programas de governo no incremento do mito da ascensão social pela escolaridade.Em meioa revisão de cunho bibliográfica desenvolvida por autores como Paiva (1976), Aguiar (1980), Martins (1975)Gnaccarini (1980) percebe-se a construção de posicionamento que permitem compreender as políticas públicas que se organizavam para o desenvolvimento do setores que alavancariam a economia do país, no entanto como eram de curto de prazo não demonstravam resultados significativos contribuindo para afirmar a crescente subordinação dos pequenos produtores ao capital financeiro. Já a educação rural era trabalhada como pano de fundo de um discurso constituinte das políticas sociais, desempenhando função ideológica estratégica para o governo do período, que a apontava como necessária para proporcionar a igualdade de oportunidades através da formação educativa que prioriza regiões reconhecidamente com menor potencial de renda. 0 alinhamento verificado entre as legislações, planos e diretrizes não eliminou o aspecto fragmentado e pragmático para a resolução dos problemas do país, uma vez que tais políticas eram elaboradas a partir de um modelo societário capitalista, que é reproduzido pelo discurso de igualdade de oportunidades, que se distancia cada vez mais da igualdade de condições. $\mathrm{O}$ cotejamento dessas diferentes fases possibilita apreender a complexidade da história da educação rural do Brasil e as desigualdades de políticas públicas inscritas nas diferenças do que era e é prioridade no país.

Palavras - chave: políticas públicas, período desenvolvimentistas, educação rural. 


\section{INTRODUÇÃO}

Para analisar a realidade da política brasileira faz-se necessário considerar o contexto de ajuste colocado aos Estados entre 1930 e 1990. Onde, como toda política pública, as políticas com fundo desenvolvimentista podem induzir a mudanças desejadas pelos governos em diferentes setores, por meio do arranjo de instrumentos que estimulem e promovam a distribuição social. Sendo assim, a orientação dessas políticas é dada pelo papel que se espera e que cumpra em um dado momento histórico.

Para compreender as entrelinhas das amarras públicas o escrito leva a análise de instrumentos que o governo apresentava para atingir suas metas desenvolvimentista como o - Crédito Rural, Política de Preço Mínimo, Pesquisa e Experimentação e Educação no Meio Rural. Somando-se a esses as análises de documentos do Ministério da Educação e Culturaque mostra que os governos, apresentaram uma clara preocupação desenvolvimentista para o espaço rural, apregoando a necessidade de viabilizar uma produção agropecuária abundante para o abastecimento do mercado interno e exportação, reduzindo simultaneamente o nível internode preços e o desequilíbrio da balança de pagamento.

Já no âmbito da educação formula-se a tese da educação como instrumento de desenvolvimento social, por caracterizar-se como um elemento dinâmico no processo de desenvolvimento, não se restringindo ao espaço da economia, mas alcança o tempo de desenvolvimento da sociedade. Deste ponto de vista, a primeira expressão tangível da política deverá começar pelo investimento na oportunidade de acesso a educação.

A influência dessa concepção de Educação Rural passa a admitir a ideia de planejamento impondo dessa forma ao Estado funções complexas de como trabalhar o ruralismo pedagógico entendido como o objetivo da fixação do homem do campo na sua terra de origem. Assim o recorte temporal aqui desenvolvido contribui para a compreensão de como as Políticas Públicas oficiais viam a educação no espaço rural e, muito especificamente, como era vista a educação do campo diante de um discurso de desenvolvimento da sociedade brasileira.

\section{ESTRUTURAÇÃO DE ÓRGÃOS DE APOIO À POLÍTICA DESENVOLVIMENTISTA DO BRASIL}

A política de crédito rural visava à modernização das forças produtivas e a compensação da política de controle de preços (MEC, 1973). Contudo, o que se viu foi uma enorme concentração do crédito entre os grandes produtores.

Segundo Paiva (1976) a política de preço mínimo, vigorante desde 1945, objetivava proporcionar aos agricultores um seguro de preço, remunerar satisfatoriamente os produtores garantindo-lhes pelo menos cobertura dos gastos de custeio, diminuir as flutuações de preços, evitar as especulações de intermediários e garantir maior suprimento de produtos agropecuários. $\mathrm{O}$ que se viu disto foi que, os preços eram fixados pelo governo em níveis muito baixos, sendo sempre superados pelos preços do mercado, não havendo assim, necessidade de que o governo adquirisse produtos.

No que se refere à Pesquisa e Experimentação, Pastore (1975) diz que esta foi também, deixada a cargo de órgãos do governo. Desde 1972 o setor público responsável pela execução da pesquisa agropecuária é a EMBRAPA. Como empresa pública, defendia estar aberta para todos os tipos de recursos financeiros e humanos, e, ao mesmo tempo, pronta a vender seus serviços para todos os tipos de clientes. 0 principal produto da empresa era a tecnologia agropecuária e seu principal cliente o governo, assim com a fundação da EMBRAPA,

Era possível adequar mais efetivamente a produção da tecnologia agropecuária ao modelo de desenvolvimento e em consequência, às suas necessidades. Procurou no plano administrativo estabelecer um mecanismo institucional dinâmico capaz de proporcionar em termos de oferta de tecnologia agropecuária, respostas eficazes àquelas necessidades e desenvolver por sua vez uma relação mais estreita com os serviços de extensão rural e as indústrias de insumos agrícolas para acelerar a difusão do conhecimento no país (AGUIAR, 1980, p. 7).

A questão de difusão do conhecimento, mencionada pelo autor, traz a tona outro órgão do governo diretamente ligado a EMBRATER - Empresa Brasileira de Assistência Técnica e Extensão Rural. Suas atividades são consideradas por Aguiar (1980) complementares às da EMBRAPA. Este autor defendia que a EMBRATER estava intimamente ligada com os problemas e necessidades do produtor. Enquanto que a EMBRAPA por meio da pesquisa criava tecnologias alternativas, a EMBRATER tem a função de difundi-las 
aos agricultores por meio do serviço de extensão rural.

Por outro lado, diz Aguiar (1980), a criação da EMBRAPA, e com ela um novo sistema de pesquisa, ocorreu num momento particular do desenvolvimento do país, onde oprocesso demodernização da agropecuária ${ }^{29}$ teve uma maior explicitação em nível governamental, para auxiliar a passagem da ênfase na exportação para o atendimento das necessidades internas.

Assim, o governo envidou esforços diretamente no rumo da modernização e industrialização da agricultura. Contou também, para isso, com iniciativas específicas no campo da Educação no Meio Rural.

A presença do governo neste espaço se dá mais especificamente na rede de Escolas Agrícolas, criadas a partir de 1946, na Lei Orgânica do Ensino Agrícola. O Decreto Lei no 9.613, de 20 de agosto deste mesmo ano, estabelecia como prioridade das Escolas Agrícolas a preparação profissional dos trabalhadores da agricultura e a prestação de assistência educativa ao setor do ensino agrícola e veterinário do Ministério da Agricultura. Eles estão incluídos como parte do sistema formador de mão deobra especializada para o setor primário da economia.Frisa-se a seguinte prioridade para a educação do campo neste período:

A preocupação atual é de formar um técnico que possa colaborar na solução dos problemas de abastecimento, produzindo gêneros de primeira necessidade e matéria- prima de melhor qualidade e de maneira mais econômica para a indústria, procedendo assim como agente de produção. Simultaneamente o mesmo profissional poderá atuar como agente de serviço para atender o mercado de trabalho, junto às empresas que prestam serviços aos agricultores (MEC, 1973 p. 16).

Porém, o que vai acontecer com esta iniciativa diretiva é que grande parte das Escolas Agrícolas passam a se localizar na área urbana ou próximo a ela e exigindo, o que se chamava, de curso de Primeiro Grau completo para admitir o aluno, portanto, de pouco acesso para a população do espaço rural. A clientela que normalmente frequentava essas escolas eramadolescentes da reduzida classe média da zona rural e jovens do espaço urbano.

A análise do Plano de Desenvolvimento do Ensino Agrícola de 2o Grau (1973) do Ministério da Educação mostra que a maioria dos alunos, entram para a Escola Agrícola aspirando principalmente acesso aos cursos superiores, principalmente agronomia e veterinária. A outra parcela de alunos aspiram empregos de técnicos agrícolas nas repartições governamentais (localizadas nas cidades), outros poucos, buscam grandes estabelecimentos agropecuários mais sofisticados.

A ação desenvolvida pelas escolas tendeu a certo grau de isolamento em relação à comunidade em que se inseriam e à realidade rural, sem muitos vínculos relevantes.

Neste sentido, o ensino agrícola, por um lado, contribuiu de forma geral precariamente para a melhoria da técnica e o rendimento da produção, e de outro, não há grandes índices de qualificação de mão deobra no campo, como queriam, por não existir identificação entre o espaço de labor familiar e a escola. Ainda, há uma contribuição quase nula no que se refere à promoção dos alunos e professores, a uma participação efetiva em relação aos problemas da comunidade, como afirma o Plano de Desenvolvimento do Ensino Agrícola de 2 o Grau (1973).

Outro aspecto importante é a da chamada educação não formal, ${ }^{30}$ principalmente em

razão das várias iniciativas oficiais que se desenrolaram neste campo, de profundas influências no campo educacional rural.

O sistema de ensino não formal teve início por meio do Serviço de Extensão, na década de trinta do século passado, surgido da identificação dos problemas gerados pelo desnível de crescimento entre a agropecuária e os demais setores da economia.

Porém, somente em 1948, com a criação da Associação de Crédito Rural e Assistência Rural - ACAR no Estado de Minas Gerais, que esta atividade tornou-se mais concreta. 0 objetivo então proposto era efetuar o crédito supervisionado junto aos pequenos agricultores. Este programa pretendia elevar o nível técnico

\footnotetext{
${ }^{29}$ Mecanização e uso de insumos, frisava o governo.

30 Oficialmente o governo entendia educação não formal como toda e qualquer ação educativa ministrada fora do sistema formal e legal de ensino, como mostra (SZMRECSANYI, 1973).
} 
das atividades agropecuárias e promover melhorias nas condições de vida das famílias. ${ }^{31}$

A partir daí, os Estados Brasileiros tentaram criar seus Programas de Extensão Rural, surgindo aí à necessidade de criação de órgãos que viessem a coordenar e apoiar financeiramente as Associações existentes.

Somente em 1956 é que efetivamente se concretizou uma iniciativa viável de educação não formal, a Associação Brasileira de Crédito e Assistência Rural - ABCAR.Szmrecsanyi (1973) registra que a atuação da ABCAR se fazia através de um trabalho voltado tanto a nível de aumento de produtividade agropecuária como também para assuntos de bem estar social.

A EMBRATER em substituição a ABCAR foi criada,pelo Decreto Federal número 75.373/1975, com os seguintes objetivos sociais de acordo com:

Artigo 4… (...) I. Colaborar com os órgãos competentes do Ministério da Agricultura na formação e execução das políticas de assistência técnica e extensão rural do país.

II. Promover, estimular e coordenar programas de assistência técnica e extensão rural, visando a difusão de conhecimentos científicos de natureza técnica, econômica e social, necessário ao desenvolvimento do setor rural. IIIColaborar com as unidades da federação na criação, implantação e operação de mecanismos com objetivos afins aos da EMBRATER (Decreto $\mathrm{n}-75.373,1975$ ).

0 autor enuncia que cabe a ela ainda desenvolver um mecanismo de ação capaz de atender às exigências de informação tecnológica do produtor e ao mesmo tempo cooperar com a pesquisa e o crédito, para a melhoria da agropecuária brasileira. Pelo fato que a EMBRATER cumpre suas atividades por meio de entidade associada denominada Empresa Brasileira de Extensão Rural - EMATER, presente em todos os Estados por força da Lei Complementar no 129/1995, conforme os registros da EMATER (2002).

Associou-se a EMBRATER, ainda, em face da preocupação com a qualificação do trabalhador, em 1971, período de implantação do Programa Intensivo de Preparação de Mão de Obra - PIPMO, (EMATER, 2002). Iniciando suas atividades buscando atender as áreas da agricultura, pecuária, pesca e silvicultura. Trazendo o objetivo de proporcionar aos agricultores, por meio de cursos, condições para a prática agropecuária correta.

Os documentos da EMATER (2002) mostram que em 1976, foi instituído, pelo governo o Serviço Nacional de Formação Profissional Rural - SENAR, órgão vinculado ao Ministério do Trabalho, com o objetivo de organizar e administrar em todo território nacional, diretamente ou em colaboração com os órgãos e entidades públicas ou particulares, programas de formação profissional rural.

Segundo a proposta de trabalho do SENAR (1998), a clientela seriam os próprios produtores envolvidos nos programas e projetos formulados e executados pela EMBRATER, visando à transferência de tecnologia e capacitação dos produtores.É importante notar, nesta retrospectiva histórica de iniciativas educacionais em torno do espaço rural que, embora variando as instituições oficiais, mantém-se o fio condutor de aproximar à agricultura as inventivas do espaço urbano, da técnica, da qualificação, da produção para o lucro e da preparação de mão deobra.

Percebe-se nas propostas do Plano Setorial de Educação, Cultura e Desportos - PSECD (1980), nas décadas de 1980 e 1990, que a escola se transforma numa fiel cumpridora de determinações alheia a ela, numa mera executora de convênios, sem muitas vezes ter condições de decidir sobre sua conveniência e implicações e obedecendo a critérios alheios à sua proposta.

Finalmente, embora o PSECD mencione a necessidade de uma melhoria do ensino a partir da relação escola comunidade, esta proposta não indica que benefícios dela deriva para a escola. Não se prevê, de forma explícita, o envolvimento de professores e alunos. Ainda, não se vislumbra a análise, pela escola, das relações que se estabelecem, nem o envolvimento de alunos e professores em sua definição. Muitas vezes, a interação que é proposta resume-se em atividades que são agregadas à rotina da escola, e que pouco interferem no ensino que é ministrado.

As políticas de educação para o campo, e da educação de forma geral, mantém aquela linha de conduta

\footnotetext{
${ }^{31}$ Embora se diga de iniciativas de educação não formal, elas continuam sob a tutela dos Estados, e ainda, não se afastam das propostas oficiais daeducação formal.
} 
voltada para o ideal de desenvolvimento, vendo, no espaço rural, um contexto de subemprego, sem desenvolvimento, atrelado a baixos salários, de pouca renda, e sem uma cultura própria de um país que pretende galgar os degraus da exportação e industrialização.

\section{A CONDIÇÃO POLÍTICA QUE TROUXE PARA PAUTA A EDUCAÇÃO NO MEIO RURAL}

Outra iniciativa do governo neste período, que embora pareça não ter uma relação direta com a educação no espaço rural, teve profundas interferências, refere-se à Política de Tributação (SENAR, 1998). Usada como ferramenta para forçar a melhor utilização da terra.

Em 1964 com o surgimento do Estatuto da Terra Lei no .4 .504 de 30 de novembro de 1964 a união, por meio do antigo Instituto Brasileiro de Reforma Agrária - IBRA, atual Instituto de Colonização e Reforma Agrária - INCRA reformulou e se encarregou de lançar e arrecadar o Imposto sobre a Propriedade Territorial Rural - ITR e alguns outros tributos rurais.

O Estatuto da Terra, conforme Paiva; Shattan e Freitas (1976) atribui à tributação o papel de subordinar o uso da propriedade privada a sua função social; estimular a racionalização da atividade agropecuária, preservando, ao mesmo tempo, os recursos naturais e, proporcionar recursos ao poder público para financiar os projetos de reforma agrária.

Sobre este aspecto autores se pronunciam que o sistema de tributação criado para atingir estes objetivos não foi suficientemente adequado.

Os critérios adotados para a classificação não se mostraram operacionais e a taxa básica adotada para o imposto cobrado aos proprietários mostrou-se muito pequena, deixando de ser o elemento provocador da subdivisão de propriedades ou o instrumento incentivador de melhor uso da terra, que dele se esperava (PAIVA, SHATTAN E FREITAS, 1976, p. 97).

Faltou, o que é claro no Estatuto da Terra, forçar os proprietários rurais que não exploram suas terras a venderem para quem produz. Por isso, a Lei anterior foi reformulada, principalmente na sua sistemática de cobrança do ITR, em 10 de dezembro de 1979, pela Lei no 6.746. Forçando-se a isto, evidentemente, e resultando na apropriaçãodessas áreas improdutivas pelos que já possuem estrutura e capital.

Esse estudo constata ainda que todas as políticas públicas para o setor agrícola pautaram-se na premissa do desenvolvimento do setor agropecuário sem, no entanto, apresentar resultados significativos, também porque, são iniciativas de curto prazo. Fica patente também, que enquanto algumas metas quantitativas foram razoavelmente atendidas, o aumento da produtividade foi muito pouco incrementado. Os ganhos de produtividade se concentraram em poucos produtos e regiões, significando que o processo de modernização foi parcial e dirigido apenas à alguns produtos.

Assim, as políticas para o meio rural destas décadas (1950 a 1990), com todos os seus limites, dificultou a diminuição das disparidades existentes no campo e, passou a acentuá-las mais. Afetou diferencialmente os produtores, gerando um processo de concentração de renda, de terras e de produção.

Alguns autores como Martins (1975) e Silva (1980) dizem que a "debilidade" das transformações capitalistas na agricultura brasileira vinculam-se, historicamente, à sua subordinação ao capital comercial. De um lado, o setor ligado à exportação encontra-se estreitamente vinculado ao capital comercial desde o período colonial e, de outro, mesmo em relação a produção para o mercado interno, o capital comercial continuou apropriando os excedentes de produção resultante das formas atrasadas de que se revestiam as relações de produção no campo, antes e ao longo do processo de industrialização. Neste sentido, afirma Martins (1975) que ainda na década de 1970 podia-se dizer que o preço dos produtos agrícolas continuou sendo fixado em função da rentabilidade do capital dos empreendimentos urbanos e não em função dos custos de produção.

Gnaccarini (1980) diz que o processo de industrialização do campo, auxiliado por políticas de educação para o espaço rural, determinou alterações nas formas de produção tradicionais. Partes dos antigos latifúndios tradicionais, assentados na exploração do pequeno produtor, se transformaram em modernas empresas agrícolas. Essa modernização tecnológica acarretou a crescente proletarização do pequeno produtor, ao eliminar as culturas de subsistênciae ao substituí-los por trabalhadores assalariados temporários. Os trabalhadores assalariados permanentes na agricultura, que tenderam a permanecer dentro das grandes fazendas, se reduziram a trabalhadores qualificados, como tratoristas e mecânicos.

Paralelamente, continua Gnaccarini (1980), parte dos pequenos produtores tradicionais, por imposição das 
propriedades maiores e tecnificadas, das agroindústrias e cooperativas, se transformaram numa camada de pequenos produtores tecnificados cuja produção depende, de um lado, dos ramos industriais que produzem meios de produção modernos para a agricultura e, de outro, dos oligopólios industriais e comerciais (inclusive as cooperativas) que controlam a comercialização dos seus produtos.Passou-se a ter:

Grandes propriedades tradicionais na exploração da renda em produto ou em trabalho do pequeno produtor;Além dos pequenos produtores ligados diretamente ao latifúndio tradicional, mantém-se outras formas de produção tradicional, como posseiros e pequenos proprietários, que combinam produção com venda da força de trabalho; Grandes empresas agrícolas capitalistas que geralmente eram especializadas em determinados ramos da agropecuária (SORJ, 1980, p. 40 ).

Os pequenos proprietários não tecnificados, garante Gnaccarini (1980), perderam a autonomia que lhes permitia assegurar as condições mínimas de reprodução da unidade familiar. Não é mais possível, para eles, diante desta realidade, ficarem alheios à dinâmica de acumulação capitalista, pois devem produzir segundo as determinações do mercado do qual dependem para as suas necessidades mais elementares. Ao final, a miséria absoluta acaba por expropriá-los em benefício do capital que vive do comércio de terras.

Como resultado desta estrutura, diz Loureiro (1980) que o desenvolvimento do capitalismo na agricultura brasileira não apresenta um processo exclusivo de proletarização ou assalariamento crescente de trabalhadores, mas também, um processo de subordinação crescente dos pequenos produtores ao capital industrial e financeiro.

A partir do que foi apresentado até aqui, as políticas de desenvolvimento para o espaço rural, na fase de industrialização do Brasil, é possível entender os rumos que foram tomados. Possibilitando, então, enfocar, diretamente, as feições que a educação assumiu neste espaço e neste tempo.

O Terceiro Plano Nacional de Desenvolvimento, de 1980 a 1985, do Ministério da Educação e Desporto, estabeleceu que as escolas no meio rural deveriam se configurar como centros de desenvolvimento rural, sintonizadas com as prioridades econômicas e sociais (BRASIL, 1980, P.16).

Andrade (1979) ao comentar o III Plano Nacional de Desenvolvimento - PND expõe que o governo defendia o espaço da educação no meio rural como prioritário ao desenvolvimento, por entender que a agricultura se configura como setor básico da estratégia de desenvolvimento.

A educação compromete-se, dentro do quadro da política social do III Plano Setorial de Educação, Cultura e Desportos - PSECD, a colaborar na redução das desigualdades sociais, voltando-se, preferencialmente, para a população de baixa renda (Ministério Da Educação e do Desporto, 1980a). Neste contexto, e fazendo igualmente eco à prioridade nacional concedida à agricultura, o III PSECD estabelece que ao se defender como linha programática fundamental a educação no meio rural, isto se faz em decorrência de aí haver uma concentração de um dos focos de pobreza mais acentuado do país.

A primeira linha programática do III Plano Setorial de Educação, Cultura e Desportos - PSECD dizia respeito à educação do meio rural, "[...] buscando um dos focos mais acentuados de pobreza no país" (Ministério Da Educação e do Desporto, 1980a, p.15). Esta linhajustifica- se, segundo o plano pelas baixas taxas de escolarização rural; os alarmantes índices de repetência e de evasão escolar; e na dificuldade de adequação da educação às particularidades da clientela rural (Ministério Da Educação e do Desporto, 1980a, p.15).

A segunda linha programática de ação era complementar à primeira, visando o atendimento à educação nas periferias urbanas. Nesta linha, afirmava-se o caráter redistributivo e mobilizador como dimensões essenciais da educação. 0 objetivo era enfatizar a educação pré- escolar e a supletiva (Ministério Da Educação e do Desporto, 1980a, p.15).

Já a terceira linha programática do III PSECD, enfatizava o desenvolvimento cultural, na tentativa de superar a exclusão das expressões populares e o caráter de privilegiamento dado à cultura elitista e intelectual (Ministério Da Educação e do Desporto, 1980a, p.16).

A quarta linha programática indicava a possível valorização dos recursos humanos ligados à educação. Objetivava-se a melhoria salarial dos trabalhadores em educação, bem como a capacitação dos recursos humanos, a fim de criar uma estrutura sólida e aperfeiçoada (Ministério Da Educação e do Desporto, 1980a, pp.16-17). 
Para levar adiante estas quatro linhas programáticas, o III PSECD ressaltava a importância do planejamento e da modernização técnicoadministrativa, buscando o planejamento descentralizado, bem como a aplicação da tecnologia à educação e produção de indicadores confiáveis (Ministério Da Educação e do Desporto, 1980a, pp.17-18).

Ressaltava também o sistema de captação e alocação de recursos para o setor educacional, requerendo a racionalização dos recursos já existentes, ao passo que "[...] nem todo aumento de dotações ou criação de novas fontes de arrecadação leva necessariamente à ampliação de oportunidades educativas para todos" (Ministério Da Educação e do Desporto, 1980a, pp.17-18).

Além de traçar quatro linhas prioritárias para a área educacional, o III PSECD trazia ainda linhas prioritárias de ações para cada região da federação brasileira. Dando ênfase as linhas referentes à região sul do Brasil “a) incentivos à municipalização do ensino de 1o grau, à cultura e ao desporto;b) estímulo à expansão e ao fortalecimento do ensino de $2^{\circ}$ grau; c) assistência ao estudante" (Ministério Da Educação e do Desporto, 1980a, pp.41-42).

Estas prioridades já indicam que a educação neste espaço tem como objeto particular, o papel de ser engajada na realidade e uma relação bastante estreita com o ambiente geográfico, sociocultural e econômico em que se insere. É neste âmbito que se entende a aprovação pelo MEC do Plano Nacional de Desenvolvimento Ministério Da Educação e do Desporto, 1980b, p.28).

\section{CONSIDERAÇÕES FINAIS}

Pensar a educação a partir de sua integração com o meio exige que se elucide, antes mesmo de sua aplicação, as necessidades dos envolvidos no processo educativo. Em outras palavras, isto equivale a dizer que o ato de ensinar exige que o mundo da vida passe a ser a realidade da ação educativa. A comunidade é então o meio de onde provém as necessidades educativas e é também a base mais imediata e primordial para a sua efetivação.

Ao tomar como ponto de partida para a educação os dados mais aconchegantes, próximos e formadores da vivência diária, cria-se condições para que no espaço escolar se possa confrontar a cotidianidade de cada um como primeiro ponto de reflexão, levando a um questionamento sobre o meio, o sistema de vida e seus problemas.

0 que traz a compreensão que sendo o mundo da vida o ponto de partida da educação, o objetivo da ciência é clarificar a visão do real, com todos os componentes intrínsecos do futuro. Sob este ângulo o trabalho profissional e o trabalho escolar apresentam virtudes formativas complementares e, em conjunto, se afiguram muito mais eficazes que separadamente.

0 trabalho entendido como momento de expressão e realização (e com ele, a vida familiar e social), constitui-se em fonte de fornecimento de dados à aprendizagem. 0 que implica entender que a educação não é mera coadjuvante do desenvolvimento. Aí estão reunidas as experiências vivenciadas, as reflexões e interrogações sobre a realidade, que no âmbito escolar se sujeitam a um processo de ordenação, hierarquização e enriquecimento, depois disto, retornam à realidade do trabalho e da sociedade.

Na prática esta forma de ver o espaço rural como atrasado e também como necessitado de modernização, levou à algumas consequências:

- O aumento linear da produtividade tem sido o grande objetivo das políticas de desenvolvimento, mas promoveram um crescimento excludente que tem sido propalado como o caminho de desenvolvimento ideal e aceitável no Brasil;

- 0 êxodo rural e o endividamento e pauperização paulatinos das populações do campo, que verificamos a partir do final da década de 1970, representam consequências claras desse viés desenvolvimentista.

- $\quad 0$ brutal aumento das favelas em metrópoles é um desses fatores. Houve, em função de opções e direcionamentos políticos, uma desconstrução da identidade (da ruralidade) brasileira, especialmente se considerados fatores históricos do modo de vida das populações, como cultura, saberes, técnicas e visão de mundo.

0 processo de modernização do meio rural, revelou-se tendencialmente voltado à concentração produtiva e à exclusão sócio-econômica. As estratégias empreendidas com base na ação das políticas governamentais com vistas ao desenvolvimento econômico e social do meio rural revelaram um perfil essencialmente voltado a interesses específicos, posto em prática por uma distribuição fortemente 
desigual dos fatores de produção, aguçados, historicamente, por uma combinação de políticas macroeconômica que reforçaram a natureza excludente do modelo de desenvolvimento.

\section{REFERÊNCIAS}

[1] Aguiar, Ronaldo Conde. Somos modernos: já nos falta feijão. Folhetim, 10 de agosto 1980, p.7.

[2] Andrade, Antônio Cabral. A Escola Agrotécnica como Centro de Desenvolvimento Rural: Problemas e Perspectivas. Palestra proferida em Inconfidentes, MG, em outubro de 1979. (mimeografado).

[3] Brasil. Referências para uma política nacional de educação do campo: caderno de subsídios. Brasília: Secretaria de Educação Média e Tecnológica/ Grupo Permanente de Trabalho de Educação do Campo, 2004.

[4] .Lei no 5.692, de 11 de agosto de 1971. Fixa Diretrizes e Bases para o ensino de $1^{\circ}$ e $2^{\circ}$ graus, e dá outras providências. Diário Oficial da União. Disponível em: http://www2.camara.leg.br/legin/fed/lei/1970-1979/lei-569211-agosto-1971-357752- publicacaooriginal-1-pl.html Acesso em: 23/04 /2017.

[5] .Decreto no 75.373, de 14 de Fevereiro de 1975. Cria a Empresa Brasileira de Assistência Técnica e Extensão Rural - EMBRATER, regulamenta dispositivos da Lei no 6.126, de 6 de novembro de 1974, e dá outras providências. Disponível em: http://www2.camara.leg.br/legin/fed/decret/1970-1979/decreto-75373-14-fevereiro-1975423956-publicacaooriginal-1-pe.html Acesso em 23/04/2017

[6] Brasil L. Leis, Decretos, ETC. Habilitações profissionais no ensino de $2^{\circ}$ grau. Rio de Janeiro, Expressão e Cultura; Brasília, INL, 1972.

[7] Ministério da Educação e do Desporto. III Plano Setorial da Educação, Cultura e Desporto - PSECD 1980/1985. Brasília, MEC/DDD, 1980a.

[8] . . República Federativa do. III PND - Plano Nacional de Desenvolvimento.

[9] 1980/1985, ano 1980b.

[10] . Planejamento Político Estratégico 1995/1998. Brasília, maio de 1995 (mimeo).

[11] Ministério da Educação e Cultura.Plano de Desenvolvimento do Ensino Agrícola de 2o Grau. Brasília, Departamento de Ensino Médio - DEM, 1973, p.16.

[12] Ministério da Educação. Educação Para Todos: A Conferência De Nova Delhi. MEC: Brasília, 1994

[13] . . Nordeste no horizonte de 15 anos, Brasília, 1987. 58p.

[14] Emater. Marco referencial para as ações sociais da Emater/RS-Ascar. Porto Alegre: Emater/RS-Ascar, 2002. 48p.

[15] Gnaccarini, José Cesar. Latifúndio e Proletariado: formação da empresa e relações de trabalho no Brasil rural. São Paulo: Polis, 1980.

[16] Loureiro, Maria Rita Garcia. Cooperativismo e reprodução camponesa. Rio de Janeiro, F.G.V., 1980.

[17] Martins, José de Souza. Capitalismo e Tradicionalismo. Estudos sobre as contradições da sociedade agrária no Brasil. São Paulo, Pioneira, 1975.

[18] Paiva, Ruy Miller; Shattan, Salomão; Freitas, Claus Floriano Trench. Setor Agrícola no Brasil. Comportamento Econômico, Problemas e Possibilidades. Rio de Janeiro, Forense- Universitária, São Paulo, Edusp, 1976.

[19] Pastore, José;ALVES, Eliseu Roberto.A reforma do sistema brasileiro de pesquisa agrícola. In tecnologia e Desenvolvimento Agrícola. IPEA, Rio de Janeiro, 1975.

[20] Senar. Missão, princípios e diretrizes. In: Neves, A. C. et al (Elab.) 2. ed. Atual. Brasília, Df: Senar, 1998. 28p. (Série Metodológica).

[21] Silva, José Francisco Graziano da. A pequena Produção e as Transformações da Agricultura Brasileira. Cadernos do CEAS. Salvador (69), set. outubro 1980, p. 56-67.

[22] Sorj, Bernardo. Estado e classes sociais na agricultura brasileira. Rio de Janeiro, Zahar, 1980. Disponível em: http://static.scielo.org/scielobooks/cjnwk/pdf/sorj-9788599662281.pdf Acesso em: 23/04/2017.

[23] Szmrecsanyi, Tomás; Queda, Oriowaldo. O papel da educação escolar e assistência técnica. In: Vida rural e mudança social. São Paulo, Cia Editora Nacional, 1973. 


\section{Capítulo 15}

\section{Crítica e trajetorias na educação do/no campo: questão agrária, movimentos sociais do campo $e$ políticas públicas32}

Aníbal Simões Filho

José de Arimateia de Oliveira Silva

Severino do Ramo Pereira de Lima

Marianna Moreira Clementino Santos

Resumo: 0 tema da educação no espaço agrário brasileiro tem sido pontual nas últimas décadas. Sendo discutido para além da pedagogia e envolvendo outras áreas do conhecimento como a Geografia. Tem-se por finalidade desenvolver uma breve explanação sobre a trajetória da educação do/no campo, destacando alguns entraves que de certo modo interferem nesse processo educacional contemporâneo, visto que essa forma de educação diferenciada ainda é recente, se comparada ao modo tradicional utilizado comumente no meio urbano, essa proposição diante da tradicionalidade despreza as relações do campo, suas especificidades consequentemente seus habitantes. A educação do/no campo se faz presente em meio à questão agrária, considerando o fato de que o campo se mostra carente de uma forma de educação que possa formar indivíduos no meio em que vivem. Mas para que isso aconteça, é necessária a existência de políticas públicas que favoreçam ou ainda reforcem o que já foi feito até o momento, criando melhorias educacionais no campo. Um outro ponto que se faz necessário na discussão é a importância dos movimentos sociais vistos como agentes de mobilização de massas da população na busca por direitos historicamente reprimidos.

Palavras-chave: Educação do/no campo, questão agrária, movimentos sociais do campo, políticas públicas.

32 Texto revisado e atualizado. Publicado anteriormente nos Anais do II CONEDU- Congresso Nacional de Educação, Campina Grande- PB. 2015, com o título (UMA TRAJETÓRIA CRÍTICA DA EDUCAÇÃO DO CAMPO: QUESTÃO AGRÁRIA, MOVIMENTOS SOCIAIS E POLÍTICAS PÚBLICAS). 


\section{NOTAS INTRODUTORIAS}

A Lei 9.394/96 (Lei de Diretrizes e Bases da Educação Nacional - LDB), resultado de diversos movimentos de caráter educacional, já demonstrava interesse às populações do campo. "Igualmente abre-se espaço para propostas de educação escolar de qualidade alternativa à conhecida Educação Rural, ou seja, a LDB "reconhece a diversidade sociocultural e o direito à igualdade e à diferença" (Parecer no 36/2001, CEB/CNE) (GOHN, 2011, p. 3- 4)".

Este trabalho tem a finalidade de fazer uma reflexão crítica da trajetória da educação do campo, alicerçada na natureza política dos movimentos sociais do campo, que se fez e necessário diante de constantes percalços da educação no Brasil, para construção de uma nova concepção de educação rural, em tese, a educação do campo, importantíssima para dá amplitude aos debates contemporâneos sobre a referida temática nos dias de hoje.

Esse trabalho possui importância além da barreira da educação formal a partir de uma reflexão critica da história e tenta chegar ao ponto atual em que estamos perante as evidentes contradições e paradigmas que, de forma geral à educação brasileira, vive de forma segregada e com pouca funcionalidade, entendamos primeiramente que a revisão histórica em que de forma geral é a base de todas as dinâmicas no território brasileiro seja de forma institucional nos constantes debates nas universidades ou social pelo censo comum nas esquinas do pensamento ideológico formados pelas constantes informações inverídicas proclamadas pelos meios de comunicação, por entre essas questões a educação em sua amplitude sempre foi um assunto a ser pensado desde mesmo antes de existirem as belíssimas instituições clássicas de conhecimento institucional.

Quando pensamos na gênese da formação do território nacional é impossível não pensarmos nos indígenas e a questão agraria em sua amplitude, e isso mostra claramente que essa questão, mesmo antes do termo propriamente ser referido por diversos meios documentais, ela já existia, pois, a terra sempre foi um bem comum àqueles que a utilizam para própria existência e não como mercadoria, com a chegada dos portugueses e consequentemente a exploração dor ser indígena, tanto por meio físico quanto mental, esse fato iniciou conflitos pela terra e por uma autonomia do ser, que podemos dizer que ai se encontrava a base dos movimentos formados por um grupo de indivíduos lutando por sua liberdade.

E da opressão que era aferida esses povos, por muito tempo esses conflitos aconteceram por anos e anos de forma diferentes de acordo com as épocas e condições pelas quais o Brasil passava logo as primeiras foram a divisão segregada do território que o centralizou nas mãos de poucos e negou qualquer tipo de direito aos povos que ali estavam muito antes do "homem branco" explorar e dominar, com a criação das capitanias hereditárias e em seguida as sesmarias o que pode ser considerado como a gênese da dinâmica tanto econômica quanto populacional desse antagônico momento, vejamos que esses fatos levaram e levam a discursões ininterruptas sobre as consequências desses fatores até os dias atuais, segundo Molina (2006 ) o fortalecimento da luta e da organização dos trabalhadores reforçam a relevância da democratização de acess oà terra, o território rural se revela como um espaço

que transcende a mera produção de mercadorias, sendo a base para os processos de transformação das condições de vida de trabalhadores excluídos pelo atual modelo de desenvolvimento; compreendemos que todos os desmembramentos históricos culminam a cada dia em novos rumos como a educação e os movimentos sociais.

A Educação do Campo não cabe em uma escola, mas, a luta pela escola tem sido um de seus traços principais: porque a negação do direito à escola é um exemplo emblemático do tipo de projeto de educação que setenta impor aos sujeitos do campo; porque o tipo de escola que está ou nem está mais no campo tem sido um dos componentes do processo de dominação e de degradação das condições de vida dos camponeses (CALDART, 2004, p.12).

Esse pressuposto de desigualdade e que nega uma educação emancipadora aos viventes do meio rural, juntamente com os pensadores que discutem a ênfase deste tema, e foram alcançando relevância apesar do curto tempo da temática, mas a questão debatida se faz antiga no ver que se faz para além das questões imediatistas e se concentram em um ponto que atualmente chamamos de educação do campo ou educação campesina,

Os movimentos sociais são contemplados por diversas características que os definem como um grupo de pessoas com os mesmos interesses e lutam por causas comuns a toda a sociedade à grosso modo, e muitos os atribuem um valor burocrático, onde deve haver uma legalização politica, perante as lei uma legitimação por parte dos que estão a frente desses movimentos, entretanto outros atribuem um valor 
mais radical que seria, a atuação propriamente dita a militância.

Destacamos a exemplo o MST, MAB e a CPT que são precursoras da luta por uma pedagogia autônoma que fortaleça a identidade campesina, mas efetivamente o MST (movimento dos trabalhadores sem terra). Segundo (CALDART, 2000), a proposta pedagógica do MST está vinculada a princípios organizativos que fundamentam a existência do próprio Movimento. A autora afirma que a um projeto de sociedade que está vinculado a um projeto de ser humano ou, no dizer de Paulo Freire, de humanização.

Esse movimento vem com a luta engajada há tempos, por condições dignas e reconhecidas de vida, entre essas condições a um "pedaço de chão" para plantar, colher e conseguir viver de forma a fortalecer a sua cultura e de uma comunidade em mais especifico e subsídios que possam dar as condições econômicas necessárias ao desenvolvimento de sua comunidade e de uma forma ampla a luta.

A ligação intrínseca dos movimentos sociais do campo com a origem de uma pedagogia coletiva e camponesa, onde antes mesmo da década de 90 já existia por entre os acampamentos e assentamentos do movimento sem terra, exemplos que, serviram de ponto inicial a reflexão sobre as questões do campo de forma geral, uma vez que essa pedagogia tem sua origem na luta por melhores condições de vida que culminou nas primeiras indagações por pesquisadores e educadores a respeito da temática. Considerando assim o ano de 1990 o inicio das efetivas primeiras movimentações politicas e científicas, que propiciaram a gênese do debate atual.

0 atual trabalho foi desenvolvido por meio de pesquisas bibliográficas em torno das questões referidas a educação do campo e suas vertentes, em livros, artigos e documentos que fundamental a temática estudada, o estudo da questão agraria se fez imprescindível no momento em que faz parte do berço da sociedade brasileira e portando legitimo ao desenvolvimento deste trabalho que lida com fatos sociais e coletivos como a educação e os movimentos sociais, estes, por sua vez fazem parte indispensável da base sociológica empregada neste trabalho com discursões que permeiam as condições de vida de grupos de indivíduos com finalidades comunais, através das leituras de documentos oficiais da republica federativa brasileiros voltados a educação como a LDB E AS DIRETRIZES CURRICULARES NACIONAIS DA EDUCAÇ̃̃O BASICA, conseguimos analisar o pilar central das politicas publicas voltadas a educação do campo, voltadas de forma geral a todos os movimentos sociais campesinos afins.

\section{RESULTADOS E DISCUSSÕES}

O processo de organização do espaço agrário brasileiro, isto é, a formação estrutural dos grandes latifúndios no campo - onde estão concentrados nas mãos de poucos - apresentam uma histórica marcada pela exclusão/espoliação dos povos nativos do campo (da terra) e, mais na frente, dos negros (exescravos). Ambos os povos considerados em um pensamento ideológico como raças inferiores.

Mediante o surgimento de diversos movimentos sociais, os sujeitos do campo tem buscado desconstruir esse conceito de inferiorizarão atribuído secularmente aos mesmos. Fato este bem observado por Arroyo (2012) apud Souza (2012). Segundo o autor, “(...) as reações politicas dos movimentos sociais indígenas, negros e quilombolas tem sentido especial, por afirmarem identidades positivas e desconstruírem hierarquias e lugares e papeis sociais desiguais e segregados" (SOUZA, 2012, p. 750).

Como se sabe, a concentração da terra e da propriedade privada foi e, ainda é hoje, a principal causa dos inúmeros embates e tensões politico-ideológica no meio rural brasileiro assinala Souza (2012).

Os conflitos por terras marcam a história brasileira, em particular o século XX, que teve a organização de movimentos, como as Ligas Camponesas, Movimento dos Trabalhadores Rurais Sem Terra (MST), Movimento dos Atingidos por Barragens; Movimento de Mulheres Camponesas; a Via Campesina, o Movimento Quilombola, entre tantos outros (SOUZA, 2012, p. 750).

Desse modo, asseguro que os processos históricos de luta no espaço rural, reflete bem o descontentamento dos povos do campo e mostra a gênese das desigualdades socioeconômica no mundo rural, envolvendo pontos como; educação, trabalho, saúde, autonomia política e econômica e lazer. Portanto, isso são questões básicas que estão à margem dessa massa, demostrando está muito distante das reivindicações manifestadas nas últimas décadas do século XX.

Ao mergulhar sobre os estudos de Maria da Gloria Ghon, "movimentos sociais na contemporaneidade", observa-se que no Brasil, os movimentos sociais sempre estiveram entrelaçados a educação e vice-versa. Segundo Gohn (2011), "a relação movimento social e educação existe a partir das ações práticas de 
movimentos e grupos sociais" (GOHN, 2011, p. 334). 0 viés educacional - seja de forma formal ou informal - e os espaços de aprendizagem (instituições educacionais, fábricas, espaços públicos, de baixo de uma árvore e etc.) constituem e direcionam as ações coletivas dos sujeitos.

À medida que a educação politiza o comportamento do Movimento, fruto da articulação de ideias e discurssões entre os participantes, ela também, conscientiza os indivíduos de seus direitos. "Os movimentos sociais não apenas reivindicam ser beneficiários de direitos, mas ser sujeitos, agentes históricos da construção dos direitos" (ARROYO, 2007, p. 162). Por isso, os sujeitos, cuja produção da vida é centrada na terra, nas tradições e costumes, na cultura, na identidade, tem nos movimentos sociais, uma organização político capaz de representar seus interesses perante o Estado.

Dessa forma, "as experiências e lutas da educação do campo colocam em evidencia a histórica desigualdade educacional da sociedade brasileira, em que os trabalhadores são os que possuem menor escolaridade" (SOUZA, 2012, p. 752). Em defesa de interesses coletivos, na qual a educação básica para o meio rural é um direito de todos, diversos órgãos sociais lutam pela concretização e amplitude desses direitos garantidos constitucionalmente aos dos povos do campo, os quais são:

Os agricultores familiares, os extrativistas, os pescadores artesanais, os ribeirinhos, os assentados e acampados da reforma agrária, os trabalhadores assalariados rurais, os quilombolas, os caiçaras, os povos da floresta, os caboclos e outros que produzam suas condições materiais de existência a partir do trabalho no meio rural; (Legislação Educacional de 2003 a 2010, p. 390).

A mobilização política dos Movimentos Sociais, sendo o Movimento dos Trabalhadores Sem Terra (MST) a principal frente de luta dos trabalhadores rurais, foram e, continuam sendo, importantíssimas e necessárias para o "acesso a terra" e a educação no campo. Outras organizações populares como "o Movimento dos Atingidos pelas Barragens (MAB), o Movimento das Mulheres Camponesas (MMC), o Movimento dos Pequenos Agricultores (MPA), Sindicatos de Trabalhadores Rurais, a Confederação dos Trabalhadores da Agricultura (CONTAG), a Rede de Educação do Semiárido Brasileiro (RESAB) e a Comissão Pastoral da Terra (CPT)" (MURANAIM, 2008, p. 5), também contribuíam decisivamente para às conquistas citadas acima.

Se prestarmos mais atenção na histórica do processo de escolarização rural no Brasil, Vendramini (2007) aponta que, as primeiras experiências educacionais (escolas, programas, currículos, propostas pedagógicas, campanhas nacionais) destinadas à população rural já existiam desde a década de 1920, que, por lógica, tinha a educação como mola propulsora do desenvolvimento social, político, econômico e ambiental. No entanto, o autor afirma que a realidade se mostrava bem diferente, as escolas rurais ofereciam uma educação precária e defasa em suas práticas de ensino.

A escolarização rural, na maior parte de sua trajetória, não passou de uma estratégia para minimizar os conflitos e tensões causadas pela onda de movimentos populares que eclodiam no campo. "A escola pública do campo e no campo se contrapõe a toda política de erradicação da infância e adolescência de suas raízes culturais, de seu território, de suas comunidades, dos processos de produção da terra e de sua produção como humanos" (ARROYO, 2007, p. 163). Quando paramos para rever as políticas educacionais do campo, em especial, o currículo conte disto, as normas e diretrizes pedagógicas e de formação de professores, tem-se a nossa vista, paradigmas urbanos inclusos, que renega o modo de vida dos diversos povos do campo.

Diante desses fatos, o Ministério da Educação em convênio com o Banco Mundial, fomenta a implantação do "Programa Escola Ativa", em 1997. O tal programa possibilitava a participação dos professores nos debates sobre a educação do campo, tendo em vista as parcerias entre os governos Estaduais, Federais, Municípios e universidades que apoiavam o movimento. Este Programa objetivava trazer para o cenário rural uma educação que atenda as demandas do campo.

Porém, ao analisar o programa, Marsiglia e Martins (2010) apud Souza (2012), fala que em vários trechos, valorizam-se as práticas docentes, a educação escolar e os conteúdos curriculares. Mas, as autoras também assinalam que, a tal iniciativa pública (Programa Escola Ativa) apresentava certas falhas em seu projeto político-pedagógico, ou seja, observa-se que a mesma na prática, não era executada de acordo com o que, em tese, foi proposto para as escolas rurais.

De modo que, se constatava "a presença do ecletismo e de contradições nas orientações pedagógicas" (SOUZA, 2012, p. 9). As propostas metodológicas, os métodos e o material didático usado para formação dos alunos para uma concepção de gestão democrática não estava seguia e nem se baseava em apenas um referencial teórico. Isso acabava confundindo o entendimento dos alunos, desviando-se de uma verdadeira 
educação emancipadora. De modo, tratava-se de um projeto-pedagógico com inúmeras limitações, com fragmentos de uma educação urbana, tende em vista, interesses hegemônicos da classe dominante.

Ainda nesse mesmo ano - julho de 1997 -, a realização do I Encontro Nacional de Educadores e Educadoras da Reforma Agrária - ENERA, organizado pelo MST e outras organizações nacionais e internacionais de natureza educacional-política-social, sinalizava mais do que um apelo pedagógico, ascendia aí, um forte apelo político, que implicou diretamente nas ações dos indivíduos que lideravam o Movimento (MUNAIM, 2008). A busca por um meio rural mais igualitário, fez dos movimentos sociais populares do campo, o principal meio de articulação política por uma Educação do Campo, desde já, passando a negar a educação rural que era oferecida pelo Estado. Ao reafirmando as palavras de Ribeiro (2012), a preocupação por parte dos educadores rurais sobre a escolaridade ofertada pelo Estado às famílias de trabalhadores rurais, se explicava pelo fato de ser uma educação de caráter urbanocêntrica, diferenciada apenas pela maior precariedade quando se comparada às escolas das áreas urbanas. Não se tratava de uma escola destinada ao desenvolvimento das técnicas e práticas camponesas, mas, instruía os sujeitos - filhos de trabalhadores rurais - à classe subalterna, portanto, sujeitos operacionalizados para o mercado de trabalho, prontos para servir as fábricas e indústrias.

O primeiro ENERA (1997) foi tão bem sucedido que, no ano seguinte, foi realizado a I Conferência: Por uma Educação Básica do Campo, em Luziânia/Go, em 1998, também organizada pelo MST, Confederação Nacional dos Bispos do Brasil (CNBB), Organização das Nações Unidas pra Educação, Ciência e Cultura (UNESCO), o Fundo das Nações Unidas para a Infância (UNICEF). Tal evento contou com a participação dos movimentos sociais do campo, bem como, os Sindicatos de Trabalhadores Rurais, as federações, a Confederação Nacional dos Trabalhadores na Agricultura (CONTAG) e a Universidade de Brasília (UnB) (RIBEIRO, 2012).

Esta Conferência veio reafirmar [...] "a legitimidade da luta por políticas públicas específicas e por um projeto educativo próprio para os sujeitos que vivem e trabalham no campo" (GOHN, 2012, p. 123). Dessa forma, implica na (re)formulação de um novo projeto de desenvolvimento para escolarização do campo. Isso se tornou um marco importante, porque logo foi criado o Programa Nacional de Educação de Reforma Agrária (PRONERA), direcionado a desenvolver uma política educacional para os sujeitos do campo, onde tem por objetivo fortalecer o meio rural enquanto território de vida em todas as dimensões: econômica, social, política, cultural e ética.

A educação do campo não emergiu do vazio e, muito menos, partiu de iniciativas do Estado. Esta modalidade educacional, "é fruto da organização coletiva dos trabalhadores diante do desemprego, da precarização do trabalho e da ausência de condições materiais de sobrevivência para todos" (VENDRAMINI, 2007, p. 123). Tendo seus ideais e objetivos firmados no sei dos movimentos sociais, na maioria do campo, para tanto, não foi uma política que se construiu do dia para noite, mas, é marcada por uma trajetória de lutas sociais de diversa natureza sócio-política.

A educação do campo tem com proposta, valorizar os sujeitos-alunos com sujeitos constituídos de identidades, arraigados desde o nascimento. Não só universalizando o direito desses indivíduos de viver conforme sua cultural, mas também, de direitos de igualdas perante a Sociedade que está inserida, desse modo, tendo a educação que lhe acha mais necessária a sua produção social. "As populações oriundas do campo são munidas tanto de propósitos quanto potentes do exercício da autonomia política e de consciência de seus privilégios políticos, muitas vezes, negados no modelo de sociedade capitalista que vivemos hoje". (GOHN, 2012).

Antes de tudo, a compreensão da educação do campo, é inegavelmente o resulta de uma visão politicamente diferenciada, que acentuada no tripé, educação, sociedade e desenvolvimento (Cavalcante, 2010), assume a função de combater as desigualdades e contradições sociais produzidas nos 500 anos de exploração dos trabalhadores que têm resistido para continuar produzindo sua vida no meio rural. E, em especial, reconhece que esta realidade não deve ser mais reproduzida, que precisa ser alterada, na perspectiva barrar a crescente pobreza, o desemprego e as dificuldades de acesso às políticas públicas (saúde, educação, transporte, infraestrutura etc.) no espaço rural.

A Política de Educação do Campo, Decreto no 7.352, de 4 de novembro de 2010, inserido na Legislação Educacional de 2003 a 2010, afirma no Art. 1ํ, que esta modalidade educacional é destinada a ampliação e qualificação da educação básica e superior para as Populações do Campo. Ainda assegura que, § 3o as escolas do campo deverão elaborar seu projeto político-pedagógico, adéqua-lo a realidade local e a diversidade cultural dos sujeitos. 
O Art. $2^{o}$ - os princípios da educação do campo: reafirma essas propostas, pois, a formulação desses projetos político-pedagógicos deverá apresentar objetivos particulares para as escolas do campo, desde então, incentive o desenvolvimento das unidades educacionais como espaços de aprendizagem e de articulação de experiências socioculturais e estudos voltados para o desenvolvimento político, econômico junto à sustentabilidade ambiental. Destacam-se também outros pontos como,

IV - valorização da identidade da escola do campo por meio de projetos pedagógicos com conteúdos curriculares e metodologias adequadas às reais necessidades dos alunos do campo, bem como flexibilidade na organização escolar, incluindo adequação do calendário escolar às fases do ciclo agrícola e às condições climáticas (...) (Legislação Educacional de 2003 a 2010, p. 390).

Contrariando essa lógica, Caúme (2006) em seus estudos, descreve que as escolas dos assentamentos do MST seguem as diretrizes do movimento. Trata-se de um currículo orientado a desempenhar as atividades camponesas, com aprendizagem de técnicas e práticas direcionadas o desenvolvimento dos sujeitos nos núcleos. Seguindo o mesmo caminho, "a educação do campo defendida pelo Movimento Camponês traz implícitos":

a)o vínculo entre a educação e a garantia da terra de trabalho; b) a superação da escola rural portadora de currículo, conteúdo e metodologia voltados à valorização do trabalho e da cultura urbanos; c) a identificação com o campo enquanto espaço político de disputas históricas dos agricultores familiares pela conquista da e permanência na terra de trabalho; d) a relação entre o trabalho desenvolvido na agricultura, na pesca e na pecuária, associado ao currículo, ao conteúdo e ao método adotados pela escola do campo; e) o reconhecimento dos agricultores familiares como sujeitos de educação e produtores de alimentos, saberes, conhecimentos e culturas (RIBEIR0, 2012, p. 465).

Esse movimento de "educação do campo" em essência traz a luta por uma educação direcionada e própria aos moradores do campo. Com isso, é possível perceber que este movimento é bem mais abrangente do que os direitos das pessoas que vivem segregados, "assim a educação do campo, a par de se constituir um movimento em si, se constitui num conteúdo, numa agenda comum de sujeitos sociais diversos". (MUNAIM,2008,p.5).

É importante ressaltar que se dependesse apenas das ações movidas pelo estado em relação à educação do campo, poderia existir a possibilidade de não haver de forma real e consistente a implementação desse processo educacional. Esse é um grande desafio para todos que lutam pela causa, nesse caso os trabalhadores do meio rural/sem terras.

Para o estado que é o responsável por essas políticas que são dirigidas para a sociedade, estratégias articuladas com o poder público podem interferir no desenvolvimento educacional rural são por vezes bem aceitas, levando assim a população às margens dos saberes técnico e à incorporação de uma educação mediana que promove uma formação voltada apenas para o mercado de trabalho, impossibilitando um aprendizado crítico.

A educação onde quer que se faça presente, seja em algum lugar ou no exercício do trabalho, será a direção para o desempenho funcional do indivíduo, a educação do campo tem como objetivo possibilitar ao homem do campo a oportunidade de trabalhar com sua realidade cotidiana, trazer para o processo de educação do campo conhecimentos novos e um ensino- aprendizagem direcionados as coisas do ambiente rural, em outras palavras, que o sujeito absorva conhecimento e aprenda novas técnicas que sejam úteis para que o mesmo use nas atividades e práticas no campo e com isso garanta seu direito a cultura e ao desenvolvimento econômico meio rural.

\section{CONSIDERAÇÕES FINAIS}

Precisamos compreender a necessidade da discursão que se encaminha a uma novo patamar que é exatamente a grande massa de trabalhos e pesquisas que estão em meio aos diversos eventos científicos no Brasil, esses trabalhos contemporâneos como o qual trabalhamos, discutem questões que de forma geral, envolvendo um novo modelo de educação a qual a sociedade nesses tempos globalizados necessita, uma formação educacional que vá além da sala de aula e dos modelos tradicionais de lecionar, em meio a diversos contextos educacionais como a educação do campo nos acampamentos assentamentos, sua importância se qualifica ainda mais pelos diversos enfrentamentos ocorridos nesse relativo pouco tempo 
em que se começou a falar dos camponeses e de sua vida de forma completa, ultrapassando com a visão manipulada no decorrer de lugares atrasados economicamente, pessoas ignorantes sem educação e um lugar apenas de produção de alimentos, eis um dos paradigmas de forma ampla encravada no DNA da historia dos movimentos sociais camponeses, a incessante luta contra a desigualdade diante das diversas faces do campo brasileiro permeiam esse trabalho, desde os primórdios da questão agraria.

\section{REFERÊNCIAS}

[1] Brasil. Programa nacional de educação na reforma agraria, Brasília-DF, Ministério do desenvolvimento agrário, http:www.incra.gov.br ,governo federal 2011.

[2] Caldart, Roseli Salete. Pedagogia do Movimento Sem Terra: Escola é mais do que escola. Petrópolis: Vozes, 2000 .

[3] Caume, David José. O MST e os assentamentos de reforma agrária: a construção de espaços sociais modelados. Passo Fundo: Ed. Universidade de Passo Fundo: Goiânia: Ed. Da Universidade Federal de Goiás, 2006.

[4] Gohn, Maria da Glória. Movimentos sociais na contemporaneidade. Revista Brasileira de Educação v. 16 n. 47. 2011, p. 333-512.

[5] Molina, Castagna, M. Educação do campo e pesquisa: questões para reflexão. In: MOLINA, M.(org).Brasil. Ministério do Desenvolvimento Agrário. Educação do campo e pesquisa: Questões para reflexão. Brasília: Ministério do Desenvolvimento Agrário, 2006, p. 9-14.

[6] Munarim, Antônio. Trajetória do movimento nacional de educação do campo no Brasil. Ed: 2008 - vol. No.01, GT-03: Movimentos Sociais e Educa. Disponível em: coralx.ufsm.br/revece/2008/01/a4.htm. acesso as 10h:35min do dia 08 de maio de 2019. 


\section{Capítulo 16}

Políticas públicas e currículo na educação de jovens e adultos: Impasses entre teoria e prática na criação e execução de ações para a modalidade e para os programas voltados ao público jovem e adulto

Nivânia Ferreira da Silva

Resumo: Esse artigo tem como problema de pesquisa inicial, a saber: Como são produzidas e desenvolvidas as políticas públicas para o Ensino Fundamental na modalidade Educação de Jovens e Adultos e como se refletem na construção e no desenvolvimento de currículos para a referida modalidade? Como os educadores e os estudantes da modalidade a enxergam e quais os desejos de melhoria trazidos por eles no que diz respeito ao trabalho nas escolas? Para isso, buscamos contribuições de autores sendo trazidos por eles elementos imprescindíveis para compreensão do tema, este que terá como objetivo geral: analisar as políticas públicas e currículos relacionadas à EJA presentes no Estado e mais especificamente à municípios da zona da mata norte onde a modalidade e programas do governo, como o Brasil Alfabetizado, Paulo Freire, Pro Jovem aconteçam, verificando sua execução e resultados e propondo a melhoria e criação de novas políticas e um currículo, através de fóruns, que abordem a Educação de Jovens e Adultos de acordo com as suas reais especificidades; como objetivos específicos: analisar as práticas existentes relacionadas às políticas e currículos da EJA e dos programas do governo presentes no cotidiano e os resultados obtidos através da execução deles; realizar atividades de intervenção junto aos envolvidos com a educação de jovens e adultos e programas, nos municípios participantes criando propostas para o melhor cumprimento das políticas existentes, valorizando e praticando um trabalho diferenciado da modalidade de ensino EJA; destacar a importância de um currículo de acordo com a realidade local para EJA, onde sejam contempladas competências e habilidades específicas ao o público-alvo.

Palavras-chave: Políticas Públicas, Currículo, Educação de Jovens e Adultos. 


\section{INTRODUÇÃO}

Pode-se denominar de Estado, o órgão responsável por administrar determinado lugar, região... estando nele a criação de políticas sociais e públicas de melhoria da qualidade de vida da população e dos serviços desempenhados através de seus comandos, entre outros aspectos.

As políticas sociais referem-se a ações que determinam o padrão de proteção social implementado pelo Estado, voltadas em princípio, para a redistribuição dos benefícios sociais visando a diminuição das desigualdades estruturais produzidas pelo desenvolvimento socioeconômico. São as formas de interferência do Estado, visando a manutenção das relações sociais de determinada formação social (HOFLING, 2001).

Já as políticas públicas são o "estado em ação", é ele implantando um projeto de governo, através de programas, de ações voltadas para os setores específicos da sociedade. É o campo do conhecimento que busca, ao mesmo tempo, colocar o governo em ação e/ou analisar essa ação e, quando necessário, propor mudanças no rumo ou curso dessas ações. (SOUZA, 2006, p.26)

Assim, o Estado vai estudando, buscando problemas, criando possíveis soluções e implantando as políticas que vão de acordo com a necessidade do público alvo da determinada situação. Nela se enquadram serviços de melhoria na saúde, no ambiente, na educação onde ano após ano são implantadas novas alternativas e em muitos casos o resultado ainda não é satisfatório.

Como exemplo, pode-se utilizar a modalidade da Educação de Jovens e Adultos que sofre o descaso da administração pública, que por muitas vezes cria projetos, programas, com metas meramente "quantitativas" baseadas em faixa etária e tempo determinado de aprendizagem beneficiando com isso setores e grupos, com mão de obra barata saída das turmas de alfabetização de jovens e adultos, através apenas da exigência de uma alfabetização muitas vezes alienada, onde só se reproduz conhecimento ao invés de produzi-lo.

Tal realidade se reflete na EJA presente nas escolas, onde o professor recebe currículos prontos, engessadas, fora da realidade e da necessidade do grupo, não há esperança de um ensino atrelado de fato ao ensino profissionalizante como ainda de maneira rude, a LDB traz sobre o ensino de Jovens e Adultos, e o que se vê ainda é a existência forte do oprimido querendo continuar sendo oprimido e do opressor na sociedade.

Portanto é preciso que aconteçam reformas nas políticas existentes e criação de novas baseadas no estudo da realidade do ensino de Jovens e Adultos, partindo nas escolas e municípios, por exemplo, da reformulação do currículo da prática das políticas voltadas ao público que ainda constam apenas no papel e da criação de outras que abranjam as reais necessidades da população tratando-a e tornando-a crítica, participativa e conhecedora de deveres e direitos.

Para toda consequência há uma ação que a precede, refletindo assim positiva ou negativamente de acordo com a situação na qual está inserida. Assim também podemos classificar o currículo como a ação que precede os planejamentos, as metodologias do professor, por exemplo, é ele que "determina" o que deve ser trabalhado, os objetivos e as habilidades e também muitos até contemplam métodos para auxiliar o trabalho docente. Porém na maioria dos casos o currículo ainda está somente nas gavetas da gestão escolar e/ou das secretarias de educação dos municípios e quando são conhecidos não há uma interpretação concisa e muitas vezes não existe espaço para discussões acerca das propostas trazidas, ele ainda é "engessado", fechado para mudanças e reformulações.

Conceitos de diversos autores são dados ao currículo onde predomina sempre entre eles a questão da organização, orientação, do traçado de caminhos dando a compreensão de que é a partir dele que tudo acontece. Mas a real importância não é dada e os sujeitos para os quais o currículo é produzido são os que se prejudicam e consequentemente a escola, o município, o estado, o país... e isso se torna ainda mais evidente em uma das modalidades de ensino que necessita de atenção diferenciada e nem sequer, em muitos casos, o mínimo é feito por ela: a EJA (Educação de Jovens e Adultos).

Paulo Freire muito conhecido devido ao trabalho que realizou focando na aprendizagem de jovens e adultos, é estritamente presente na pesquisa pois sua colaboração com o período das mudanças foi de real importância, tanto que até hoje seus métodos são utilizados e o sucesso na aprendizagem é certo, pois defende que o currículo deve ser diferenciado partindo da subjetividade do sujeito e não de metas e objetivos que alguém que está no "poder" ache que deve ter sem conhecer a realidade dos outros para os quais o currículo está sendo produzido e muitas vezes imposto. 
Moreira e Candau (2003) trazem reflexões pertinentes acerca do currículo desde sua(s) definição (ões), sua prática nas escolas e as suas consequências. Definem o currículo com a ideia de:

[...] currículo como as experiências escolares que se desdobram em torno do conhecimento, em meio a relações sociais, e que contribuem para a construção das identidades de nossos/as estudantes. Currículo associa-se, assim, ao conjunto de esforços pedagógicos desenvolvidos com intenções educativas.

Para Moreira (1990) apud Eugênio (2004) as origens do pensamento curricular no Brasil podem ser localizadas nos anos 20 e 30, quando importantes transformações econômicas, sociais, culturais, políticas e ideológicas processaram-se em nosso país. Argumenta que a literatura pedagógica da época refletia as ideias propostas por autores americanos associados ao pragmatismo e às teorias elaboradas por diversos autores europeus, buscando superar as limitações da antiga tradição pedagógica jesuítica e da tradição enciclopédica, que teve origem com a influência francesa na educação brasileira, e esforçavam-se para tornar o quase inexistente sistema educacional, consistente no novo contexto.

A partir daí ocorreram muitos movimentos como as revoluções industriais, o tecnicismo, Mobral e Paulo Freire com uma nova perspectiva na EJA até hoje, onde as carências são muitas mesmo após anos de reformas políticas educacionais pois lidar com as diferenças não é fácil, porém necessário para que as melhorias aconteçam.

Moreira e Candau (2003, p.161) complementam dizendo:

[...] a escola sempre teve dificuldade em lidar com a pluralidade e a diferença. Tende a silenciá-las e neutralizá-las. Sente-se mais confortável com a homogeneização e a padronização. No entanto, abrir espaços para a diversidade, a diferença e para o cruzamento de culturas constitui o grande desafio que estar chamada a enfrentar.

Para Apple (1995, p. 37-38), o espaço do currículo precisa ser definido como um campo complexo e dinâmico, mediado por relações de poder, de classe, raça, gênero, mas não só isso. Neste espaço também emergem desejos, expectativas e necessidades dos sujeitos que nele interagem.

O currículo exerce um poder tão grande que se for produzido e praticado com competência respeitando e trabalhando a partir da singularidade e da subjetividade dos sujeitos envolvidos, refletirá numa mudança positiva extraordinária onde o sucesso da aprendizagem acontecerá. Mas para isso é preciso pesquisa, conhecimento, mudança de atitudes, compromisso, coragem... para que as cenas observadas de docentes e toda a equipe escolar trabalhando por prêmios que serão conquistados, se os números das avaliações prontas que são enviadas para escola forem bons, e infelizmente a real preocupação com a educação não acontece, é como Freitas (2012) diz "que haja garantia da educação como um direito e não como uma mercadoria".

Assim, a preocupação com todo o ensino e ainda mais quando se trata da EJA, é muito forte uma vez que nos deparamos com um regresso da história do currículo e dos modelos de escola, que valorizam a "aprendizagem comprovada com os números", a aprendizagem mecânica, tecnicista... é mais cômodo agir assim do que investir em reformas das políticas educacionais e movimentos relacionados à ela que de fato venham trazer benefícios reais para o país, sendo assim o currículo um grande agente para essa mudança.

Para isso foram traçados alguns objetivos para essa pesquisa. Como objetivo geral: analisar as políticas públicas e currículos relacionadas à EJA presentes no Estado e mais especificamente à municípios da zona da mata norte onde a modalidade e programas do governo, como o Brasil Alfabetizado, Paulo Freire, Pro Jovem aconteçam, verificando sua execução e resultados e propondo a melhoria e criação de novas políticas e um currículo, através de fóruns, que abordem a Educação de Jovens e Adultos de acordo com as suas reais especificidades; como objetivos específicos: analisar as práticas existentes relacionadas às políticas e currículos da EJA e dos programas do governo presentes no cotidiano e os resultados obtidos através da execução deles; realizar atividades de intervenção junto aos envolvidos com a educação de jovens e adultos e programas, nos municípios participantes criando propostas para o melhor cumprimento das políticas existentes, valorizando e praticando um trabalho diferenciado da modalidade de ensino EJA; e destacar a importância de um currículo de acordo com a realidade local para EJA, onde sejam contempladas competências e habilidades específicas ao o público-alvo.

\section{METODOLOGIA}


A pesquisa realizada é de caráter inicialmente de revisão de literatura, porém serão realizadas visitas, entrevistas, estudos de campo, atividades de intervenção a determinadas escolas e municípios onde o ensino de EJA como modalidade e os programas do governo estão presentes observando o trabalho realizado e a sua relação com o currículo bem como as políticas públicas praticadas, detectando possíveis dificuldades, suas causas e possíveis soluções.

Pretendendo utilizar o subsídio teórico os autores Michael Apple, Moreira, Silva, Freire, Eugênio e Vera Maria Candau, entre outros para dar suporte teórico e também ampliar e direcionar os conhecimentos relacionados às políticas educacionais, currículo e a modalidade de ensino da Educação de Jovens e Adultos.

Analisamos a luz da pesquisa-ação que busca o envolvimento da comunidade na análise de sua própria realidade. Ela se desenvolve a partir da interação entre pesquisadores e membros das situações investigadas. Thiollent (2011) define esse tipo de pesquisa como pesquisa social com base empírica, que seria concebida em associação com a resolução de um problema coletivo, no qual os pesquisadores e os participantes estariam envolvidos de modo cooperativo. Ou seja, é uma forma de engajamento sóciopolítico a serviço das classes populares ou grupos desfavorecidos. A pesquisa-ação apresenta segundo Demo (1995), três momentos essenciais, a saber: o auto diagnóstico, que seria a confluência entre conhecimento científico e saber cotidiano; a estratégia de enfrentamento prático dos problemas encontrados; o momento da definição da estratégia de enfrentamento do problema.

Pois, nesse sentido concordamos com Ferraço (2008), quando diz que nas pesquisas com os cotidianos, os praticantes, mais do que objetos de análises, são também protagonistas e autores das pesquisas no coletivo com os pesquisadores.

\section{CONCLUSÕES}

A Educação de Jovens e Adultos como modalidade, ao decorrer do tempo sofreu e sofre muitas modificações principalmente no que se refere ao financiamento, também a promoção de formação para os professores, que são incluídos na EJA, muitas vezes, sem nenhuma orientação de como devem desenvolver uma prática pedagógica nessas turmas e acabam muitas vezes bitolando os estudantes a reproduzirem o que é destinado às classes regulares do ensino fundamental e médio. As políticas públicas inexistentes ou mal formuladas, produzidas de "cima para baixo" são muitas vezes as causas de grandes problemas enfrentados pela modalidade em nossa sociedade.

As políticas públicas não surgem como remédio para todos os males, mas como conquista que se impõe como resultado de uma realidade vergonhosa diante da sociedade contemporânea e do mundo globalizado. $\mathrm{O}$ acesso, ingresso, permanência e conclusão dos estudos a esse grande contingente de excluídos do nosso país precisa ser levado a sério sendo a limitação de financiamentos destinados a EJA um problema a ser resolvido.

Não é suficiente estabelecer objetivos nem aprovar leis bem planejadas e bem intencionadas. Falta primeiro conhecer a escola, os alunos, o currículo e quais mecanismos permitem a mudança. As Políticas Públicas são um problema para a erradicação do analfabetismo, contudo a aprendizagem ineficiente do estudante também é um dos grandes problemas da educação brasileira. Não há soluções fáceis nem um atalho para conseguir o sucesso educacional, será necessário a participação da sociedade como um todo para incidir sobre as desigualdades educativas na busca constante por esse ideal.

Freire há muito tempo já mostra a necessidade de um trabalho mediado, onde a realidade, a história do sujeito seja parte integrante das situações didáticas em sala de aula, principalmente para o grupo jovem e adulto. Sem a apresentação e compreensão de significado não há aprendizagem.

É preciso que se entenda e se trabalhe o sujeito como ser completo como ele é, que opina, que compara, que tem objetivos concretos que o levam a procurar a escola, e não como mais um que vem apenas para completar a turma mas que é considerado normal que ele desista antes do término do ano letivo.

Dessa forma, fica evidente a necessidade de um trabalho efetivo na promoção de melhorias para a EJA, que se analisem as políticas públicas existentes para a modalidade, que se promovam movimentos como os Fóruns para que todos os envolvidos como professores e alunos tenham vez e voz sobre as reais necessidades de melhoria da modalidade, entendendo o estudante como o principal componente desse grupo e que é nele, ser singular, que estão as respostas para a melhoria da Educação de jovens e Adultos. 
Realizar um estudo da EJA é uma forma de contribuir no debate pedagógico, principalmente quando ele está inserido no espaço de uma escola do interior. Refletir com docentes e estudantes é um passo importante nessa tarefa.

Finalizando esse estudo é importante registrar a necessidade de refletir sobre os problemas educacionais na EJA, sendo um deles as Políticas Públicas e para que mudanças significativas se efetivem no cumprimento das metas previstas, é necessário a participação da sociedade.

\section{REFERÊNCIAS}

[1] Aplle, M. W. Ideologia e Currículo. Tradução Figueira, V. 3 ed. Porto Alegre, Artmed, 1995.

[2] Brasil. Lei n. 9394/96 de 20/12/1996. Lei de Diretrizes e Bases da Educação Nacional (LDB). 5ª Ed. Brasil, Brasília, 2010.

[3] Demo, Pedro. Metodologia Cientifica Em Ciências Sociais. São Paulo: Atlas, 1995.

[4] Ferraço, Carlos Eduardo. Cotidiano escolar, formação de professor(as) e currículo. - 2. Ed. São Paulo: Cortez, 2008.

[5] Fernandes, C. de O. Indagações sobre currículo: currículo e avaliação / [Cláudia de Oliveira Fernandes, Luiz Carlos de Freitas]; organização do documento Jeanete Beauchamp, Sandra Denise Pagel, Aricélia Ribeiro do Nascimento. Brasília: Ministério da Educação, Secretaria de Educação Básica, 2007.

[6] Ferreira, D. C. Caderno Temático sobre a EJA (Educação de Jovens e Adultos), 2008. Disponível em: <http://www.diaadiaeducacao.pr.gov.br/portals/pde/arquivos/1711-6.pdf> Acessado em 29/07/2017.

[7] Freire, P. Pedagogia da Autonomia: saberes necessários à prática educativa. São Paulo: Paz e Terra, 2001.

[8] Freire, P. Pedagogia do Oprimido. Rio de Janeiro: Paz e Terra, 2002.

[9] Hofling, Eloisa Mattos. Estado e políticas (públicas) sociais. Cadernos Cedes, ano XXI, no 55, novembro/2001. Disponível em: http//: scielo.br. Acessado em 01/08/2017.

[10] Moreira, A. F. B. Indagações sobre currículo: currículo, conhecimento e cultura / [Antônio Flávio Barbosa Moreira, Vera Maria Candau]; organização do documento Jeanete Beauchamp, Sandra Denise Pagel, Aricélia Ribeiro do Nascimento. - Brasília: Ministério da Educação, Secretaria de Educação Básica, 2008.

[11] Moreira, A. F. B. Currículos e Programas no Brasil. Campinas: Papirus, 1990.

[12] Moreira, A. F. B. e Candau, V. M. Educação escolar e cultura(s): construindo caminhos. Revista Brasileira de Educação. N. 23, p. 156-168, 2003.

[13] Souza, Celina. Políticas Públicas: uma revisão da literatura. Sociologias, Porto Alegre, ano 8, no 16, jul/dez 2006, p. 20-45. Disponível em:http//:scielo.br. Acessado em: 02/08/2017 


\section{Capítulo 17}

Contribuições do projeto gráfico do livro para a leitura de literatura infantil: Análise de obras do PNBE

\section{Manoilly Dantas de Oliveira \\ Sayonara Fernandes da Silva \\ Andrialex William da Silva}

Resumo: A sofisticação do design do livro infantil tem exigindo cada vez mais da formação do leitor, tendo em vista a multimodalidade de linguagens presente neste objeto. Dessa forma, o presente artigo apresenta resultados da etapa teórica de uma pesquisa de iniciação científica. 0 objetivo deste trabalho é analisar o projeto gráfico de quatro livros de Literatura Infantil que constituem acervos de escolas públicas, distribuídos por meio do Programa Nacional Biblioteca da Escola - PNBE no ano de 2012 para as escolas públicas do pais. A pesquisa é de natureza bibliográfica e adotou como corpus os livros 0 sonho que brotou de Renato Moriconi (2011), Como reconhecer um monstro de Gustavo Roldán (2011), Rosita Maria Antonia Martins da Silva de Ana Terra (2011) e Cabelo doido de Neil Gaiman (2010). A análise considerou quatro aspectos do design dos livros: a ilustração, a relação entre o texto e a imagem, o formato e a fonte tipográfica. 0 estudo revela que os aspectos gráficos, além de fazer parte do objeto livro, podem interferir significativamente na leitura e recepção do texto, ressaltando a relevância de considerá-los na leitura do livro de literatura infantil. Por esse motivo, o docente, como mediador, deve ter domínio desses conceitos para ampliar a experiência estética e a leitura do livro ilustrado.

Palavras-chave: Literatura infantil. Leitura. Projeto gráfico. 


\section{INTRODUÇÃO}

A leitura é um saber básico para todo ser humano, uma vez que a sociedade em que se está inserido é letrada e por isso ele está cercado por diversas linguagens o tempo todo. Dessa forma, compete ao professor a mediação no processo de formação de leitores desde a educação infantil.

Defende-se que ler não se limita à decodificação de palavras, considerando a linguagem verbal apenas uma das formas de leitura. Em conformidade com Yunes (2010, p. 54), leitor é aquele que é "leitor de imagens, leitor de várias linguagens, leitor da política, leitor efetivamente compromissado com o seu olhar crítico".

Um dos instrumentos utilizados na escola para efetivar o processo de aprendizado da leitura é o livro de literatura infantil. Ele é um objeto cultural e está presente no cotidiano do professor e do aluno. Por ter presença imprescindível na escola e na formação do leitor, olivro é um instrumento pedagógico.

Ele é um objeto sofisticado e isso se deve ao trabalho realizado por designers, editores, autores e ilustradores. Essa complexa rede de linguagens e influências que configura o livro transformou o modo de ler, pois ele traz consigo diversas linguagens, não se limitando apenas à escrita. Em outras palavras, o leitor se vê desafiado a interagir não somente com o texto verbal, mas também com as outras linguagens plásticas ali apresentadas. De acordo com Linden (2011), ler o livro ilustrado vai além do texto e da imagem, o leitor precisa ler o formato, perceber a relação da capa e conteúdo, e em decorrência disso "ler um livro ilustrado depende certamente da formação do leitor" (LINDEN, 2011, p. 9).

0 que antes se limitava à leitura de palavras, hoje se expande para a leitura de imagens, de cores, da diagramação e outros aspectos gráficos e imagéticos. Essas relações entre os aspectos do projeto gráfico expostas no livro contribuem para a significação do texto, pois pode ressaltar detalhes e informações que colaboram com a linguagem verbal. Sendo assim, pode-se afirmar que o projeto do livro participa do processo de leitura, mas para alcançar a compreensão mais ampla e profunda, o leitor precisa saber ler essas linguagens, razão pela qual a formação do professor nessa temática é imprescindível.

Assim como na leitura da palavra, a leitura das linguagens, ali implicadas, precisa ser ensinada. Em conformidade com Joly (2012), pelo fato de os leitores estarem tão imersos nas várias linguagens que o mundo contemporâneo e suas tecnologias oferecem, a imagem é tida como linguagem universal dando a impressão de que sua leitura é realizada naturalmente. Isso se deve pela "rapidez da percepção visual, assim como a aparente simultaneidade do reconhecimento de seu conteúdo" (JOLY, 2012, p. 42). Entretanto, é preciso entender que não há diletantismo na produção da linguagem plástica do livro. Ilustradores e editores são profissionais qualificados com domínio especializado, de maneira que colocam em circulação no produto final, livro, uma variedade de possibilidades semânticas. Por essa razão, é preciso ensinar a ler a linguagem visual, aguçar a observação e sensibilizar o olhar favorecendo uma interlocução significativa no processo de leitura do livro.

Para isso, é preciso que o mediador da leitura, no caso da escola, o professor, conheça os aspectos gráficos e saiba como explorá-los na aula de leitura. Entretanto, observa-se que na bibliografia especializada essa demanda não tem sido suficientemente investigada, o que justifica a realização deste estudo.

Pouca atenção tem sido dada a essa função mediadora do professor do ensino das primeiras séries. É ele o responsável por introduzir as crianças no mundo da leitura e tem como material imprescindível de seu trabalho o livro de literatura infantil, por isso se entende que é de fundamental importância que ele conheça o livro como objeto plástico. Do professor são exigidas as habilidades de iniciação à leitura e ao conhecimento do seu suporte mais convencional - o livro.

Sendo assim, o presente artigo objetiva analisar o design gráfico de quatro livros de literatura infantil distribuídos para todas as escolas públicas do Brasil por meio do Programa Nacional Biblioteca da Escola (PNBE) no ano de 2012, dialogando com os referenciais teóricos estudados.

\section{CAMINHO METODOLÓGICO}

0 estudo é de natureza bibliográfica, foram investigados os aspectos gráficos de livros de literatura que circulam nas bibliotecas do ensino fundamental por meio do acervo do Programa Nacional Biblioteca da Escola - PNBE. O corpus literário foi adotado na pesquisa por sua abrangência nacional, haja vista que o programa distribui livros de literatura infantil para todas as escolas públicas do Brasil, portanto, está acessível aos professores de toda a rede de ensino municipal, estadual ou federal que atende a educação básica desde o segmento de creche até o ensino médio. 
Foram realizadas as leituras dos referenciais teóricos que ajudaram na construção dos conceitos basilares para o desenvolvimento deste estudo. Dessa forma, estudaram-se o Programa Nacional Biblioteca da escola (PNBE), a formação do leitor e o uso da Literatura Infantil na escola. Além disso, foram realizadas leituras sobre design gráfico, os componentes do livro ea construção história desse objeto.

Após as leituras dos referenciais e das observações em livros de literatura, foram selecionados quatro livros de Literatura Infantil do acervo do PNBE 2012. Os livros escolhidos para análise foram:

a) 0Como reconhecer um monstro (2011) autor e ilustrador Gustavo Roldan, tradutora Daniela Padilha (figura 1).

Figura 1 - Capa do livro Como reconhecer um monstro.

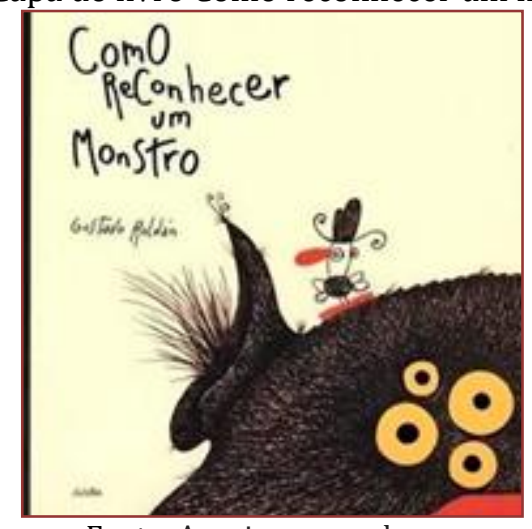

Fonte: Arquivo pessoal.

O autor traz no livro características de um monstro convidando o leitor a ler o texto e ao mesmo tempo conferir as informações na ilustração sobre como reconhecer a criatura, porém em um tom cômico.

b) Cabelo doido (2010) do autor Neil Gaiman, ilustração de Dave Mckean, traduzido por Leonardo VillaForte (figura 2).

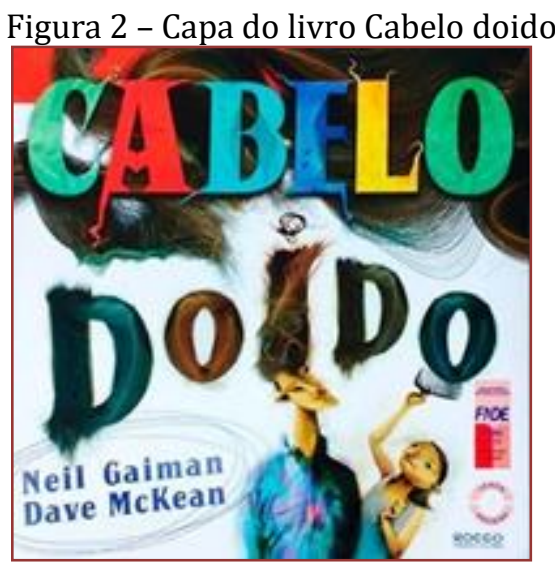

Fonte: Arquivo pessoal.

O livro conta a história de Bonnie que conhece um homem com cabelos que ela nunca tinha visto antes. 0 homem conta a ela que naquele cabelo vivem leões, borboletas, dançarinos e navios piratas.

c) Rosita Maria Antonia Martins da Silva (2011) de Ana Terra, com ilustrações da autora (figura 3). 
Figura 3 - Capa do livro Rosita Maria Antônia Martins da Silva.

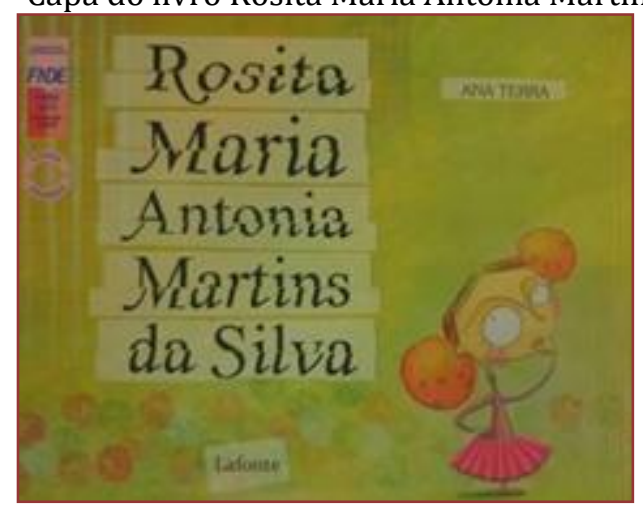

Fonte: Arquivo pessoal.

Rosita não gostava de seu nome, pois era muito grande. Para ela bastava apenas Rosi. Ela começa a ter ideias de nomes, mas são tantas as possibilidades que ela acaba querendo escapar de seus próprios desejos.

d) 0 sonho que brotou (2010) de Renato Moriconi, ilustração e projeto gráfico do autor (figura 4).

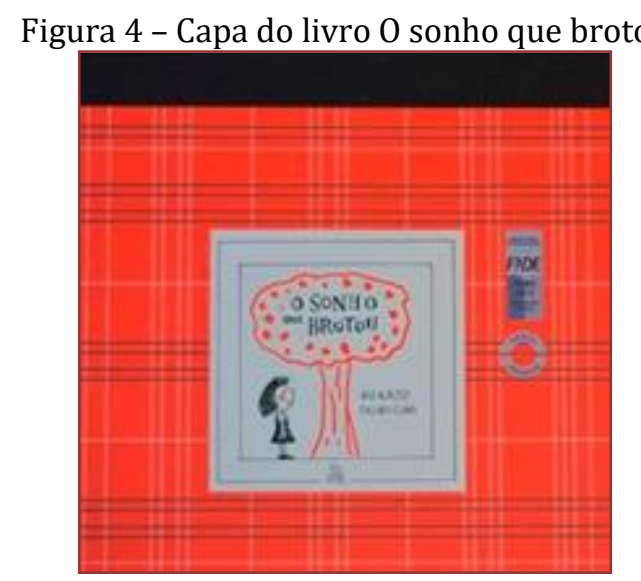

Fonte: Arquivo pessoal.

O livro conta a história de uma menina que desenhava tudo o que via, mas aconteceu que seus desenhos começaram a brotar.

Os critérios adotados para a seleção desses livros foram: a) constituírem o acervo do PNBE, tornando-os acessíveis; b) apresentarem narrativa em linguagem estética, lúdica com jogos de sentidos e, c) possuírem projeto gráfico de qualidade (A ilustração complementa o texto; a tipografia participa das imagens, entre outros). Por fim, foram feitas reflexões relacionando-se os referenciais teóricos estudados ao corpus selecionado.

\section{A ANÁLISE}

Antes de tudo é imprescindível entender o que é o projeto gráfico de um livro. Pode-se dizer que é o planejamento do livro impresso, ou seja, é o conjunto de elementos que dão características visuais e estéticas ao livro. De acordo com Moraes (2008), são as escolhas referentes ao projeto gráfico do livro que definem o corpo e a alma do objeto. Para ele,

[...] o objeto chamado livro tem um corpo, isto é, forma, tamanho, cor, tato, cheiro, etc., que é como ele se apresenta para nós, aos nossos sentidos. [...] Seu conteúdo, o qual chamei de alma, vai ser revelado à medida que percorremos seu texto, vemos suas imagens, passamos suas páginas, adentramos seu 
interior, sua atmosfera, os caminhos que ele propõe imaginar (MORAES, 2008, p. 49).

Em outras palavras, a relação entre corpo e alma vai constituir o projeto gráfico. Hendel (2006) afirma que o bom design de livro é aquele que está posto a serviço da palavra, isto é, aquele que não distrai os olhos do leitor, mas o conduz para experimentar a palavra, contribuindo para a qualidade da leitura. Ainda em conformidade com o autor, entretanto, não é só a palavra que dá sentido ao livro, mas todo o conjunto da obra. "Não é somente o que o autor escreve num livro que vai definir o assunto do livro. Sua forma física, assim como sua tipografia, também o definem. Cada escolha feita por um designer causa algum efeito sobre o leitor" (HENDEL, 2006, p 11). Portanto, itens que muitas vezes o leitor não percebe podem interferir significativamente no sucesso de sua leitura.

Assumindo essa visão, defende-se neste trabalho que o design irá possibilitar sentidos e oferecer pistas sobre o assunto do livro. Por isso, a leitura do livro de literatura infantil necessita de uma mediação eficaz, exigindo o conhecimento desses aspectos da parte do docente, além de ser necessário dominar um repertório literário infantil.

Conforme Camargo (1995, p.16), “o projeto gráfico abrange formato, número de páginas, tipo de papel, tipo e tamanho de letras, mancha, diagramação, encadernação, o tipo de impressão, número de cores de impressão". Dentro dessa amplitude, que é o mundo do design do livro, foram destacados neste estudo apenas quatro aspectos: o formato, a fonte tipográfica, a relação entre texto e imagem e a ilustração.

\section{O FORMATO DO LIVRO}

O formato é um dos primeiros aspectos que atrai em um livro. De acordo com Hendel (2006, p.34), "o design começa com a forma física do livro - o formato", pois suas dimensões atraem de imediato o olhar do leitor. Ele se torna determinante como expressão da materialidade do objeto.

O livro Rosita Maria Antonia Martins da Silva (2011) tem formato horizontal (figura 5), dito à italiana (26 $\mathrm{cm}$ x $21 \mathrm{~cm}$ ). Esse formato chama a atenção por ser diferente do padrão, e, de acordo com Linden (2011, p. 53), "por ser mais largo que alto, permite uma organização plana das imagens, favorecendo a expressão do movimento e do tempo, e a realização de imagens sequenciais".

Figura 5 - Livro Rosita Maria Antonia Martins da Silva, p. 10-11.

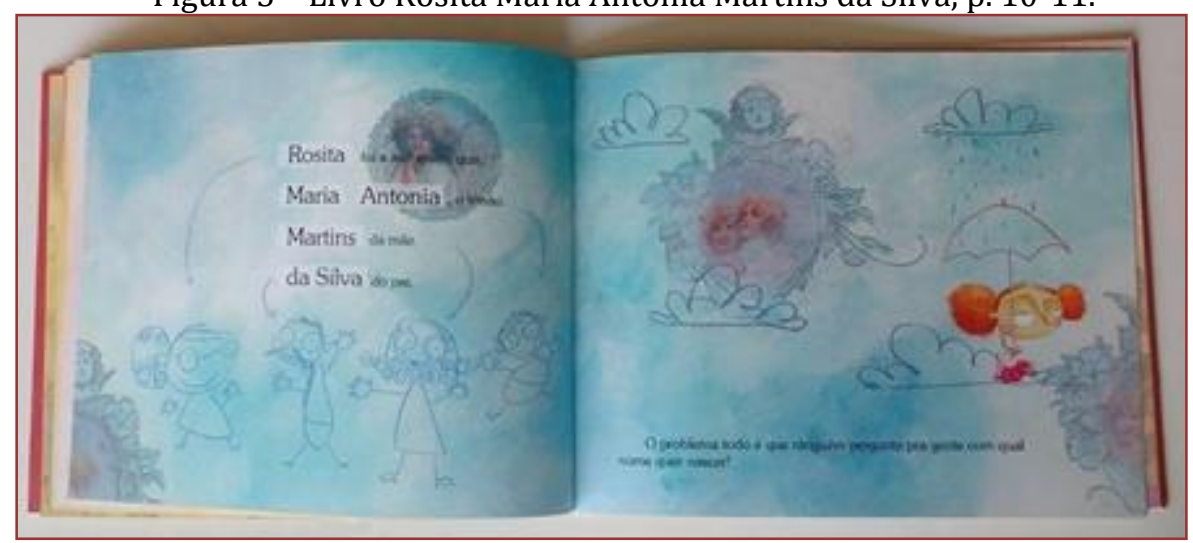

Fonte: Arquivo pessoal.

Outro exemplo é o livro $O$ sonho que brotou (2010). Ele é quadrado $(25 \mathrm{~cm} \times 25 \mathrm{~cm})$, e em uma primeira vista reproduz o modelo de manuseio do códice (da direita para a esquerda), porém, a disposição do texto é vertical (figura 6). 
Figura 6 - Livro 0 sonho que brotou, p. 37-38.

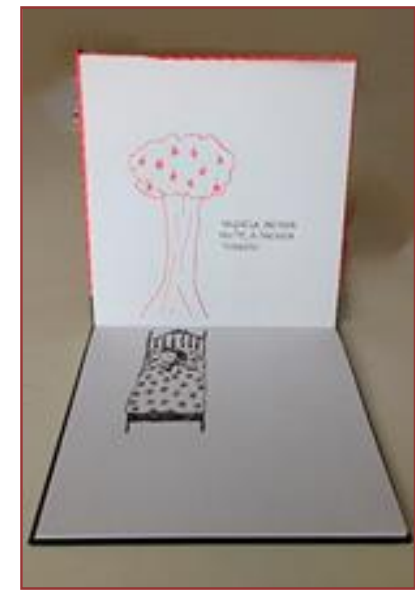

Fonte: Arquivo pessoal.

O leitor acostumado a manusear livros em formato códice, surpreende-se com esse manuseio vertical incomum. Essa mudança estrutural do design agrega componente lúdico ao objeto, uma vez que essa disposição desautomatiza o leitor.

\section{AS ILUSTRAÇÕES}

As imagens são partes constitutivas dos livros de literatura para a infância. Seja pela atração que exercem no olhar, seja por razões estruturais, as imagens são parte do projeto gráfico desses livros.

Os livros analisados neste estudo apresentam no uso das ilustrações a função de complementação. De acordo com Faria (2004, p. 40-41), o livro com ilustrações tem dupla narrativa, cada uma de acordo com sua linguagem. E, ainda em conformidade com a autora, a boa ilustração é aquela que complementa. Com a função de complementaridade, o texto escrito complementa a ilustração e a ilustração o texto escrito, pois cada linguagem, de acordo com sua constituição, expressa o que a outra não poderia dizer.

Sobre a ilustração, podem-se destacar duas características no livro Como reconhecer um monstro (2011). A primeira é que as imagens são apresentadas de maneira fragmentada, e como consequência, o leitor não consegue entender, de imediato, totalmente do que se trata (figura 7 e 8). Isso está relacionado ao objetivo do livro. A ideia é que o leitor confira no decorrer do texto as partes do monstro, por isso o enfoque nas partes a que a linguagem verbal se refere.

Figura 7 - Página dupla do livro Como reconhecer um monstro.

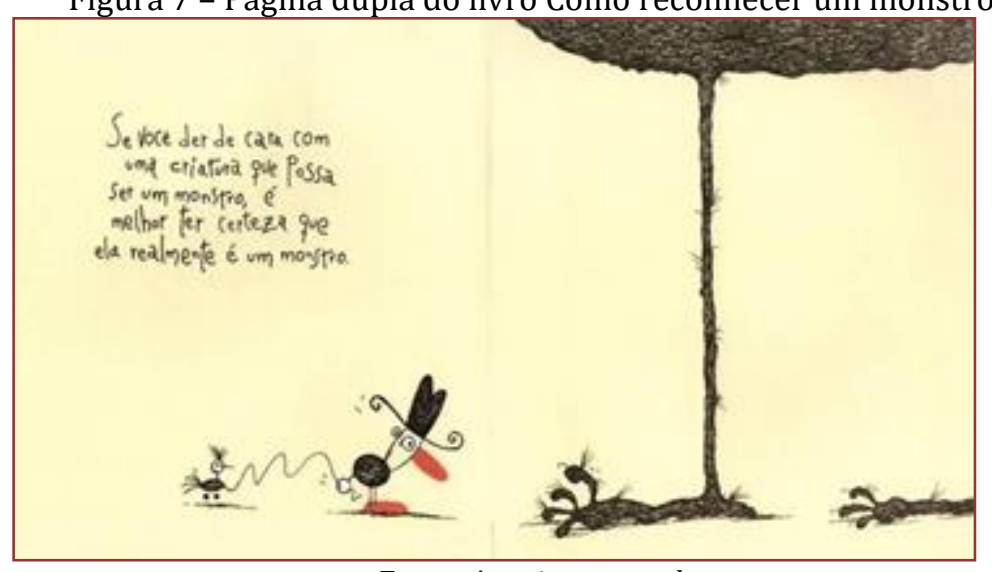

Fonte: Arquivo pessoal. 
Figura 8 - Página dupla do livro Como reconhecer um monstro.

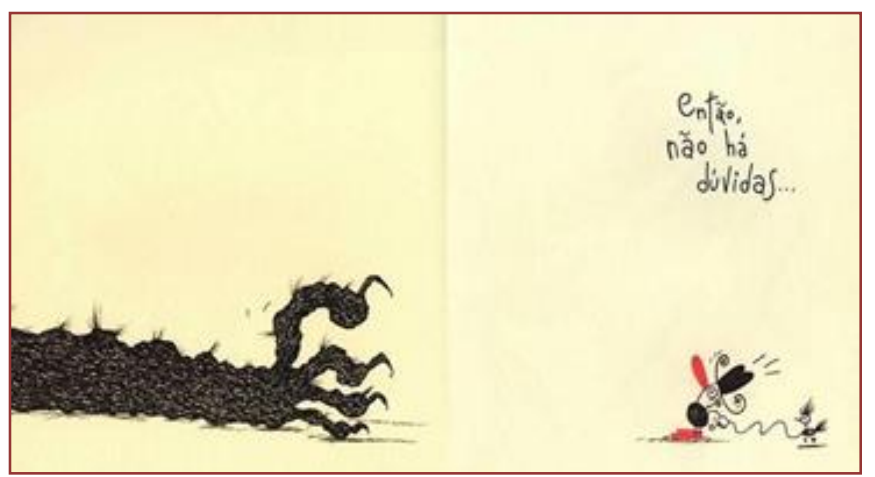

Fonte: Arquivo pessoal.

Esse jogo de ângulos mimetiza a percepção do personagem que também não tem, inicialmente, a visão total do que vê. A segunda característica a se destacar é a ideia de movimento que as imagens em sequência trazem (figura 9).

Figura 9 - Falsa folha de rosto, folha de rosto, primeira e última página dupla do livro Como reconhecer um monstro, respectivamente.

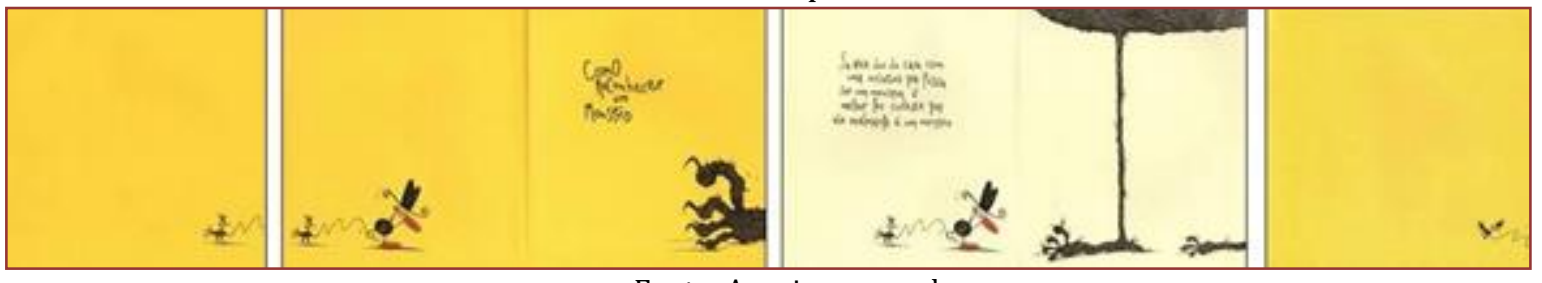

Fonte: Arquivo pessoal.

Conforme o personagem avança na narrativa, sua imagem também progride na disposição da página, da esquerda para a direita, imitando a progressão da ação. Esta ideia érepresentada, literalmente, em todo o livro, pois essa característica inicia na falsa folha de rosto e vai até a última página.

Além disso, pode-se dizer que esta obra é um caso típico de interlocução entre imagens e palavras. A história depende do ângulo de visão do personagem sobre a imagem para que o texto verbal faça sentido. A narrativa brinca com a expectativa do leitor de que o personagem tenha se enganado, enquanto, página a página, vai se consolidando a figura de um monstro.

\section{A RELAÇÃO TEXTO E IMAGEM}

A relação que a linguagem escrita estabelece com a imagem pode trazer contribuições para a significação do texto. De acordo com Linden (2011, p. 65), "o livro ilustrado mantém estreita relação com a página dupla. Assim, é determinante a forma como textos e imagens se inscrevem nesse espaço".

Foi perceptível nos livros analisados que o texto e a imagem estabelecem entre si uma relação de colaboração, isto é, apesar de linguagens diferentes eles se articulam para construir um único discurso com um único objetivo. Sendo assim, pode-se afirmar que texto e imagem têm entre si uma relação de colaboração. Nesta relação, "o sentido não está nem na imagem nem no texto: ele emerge da relação entre os dois" (LINDEN, 2011, p. 121).

Esse resultado pode ser observado no livro Rosita Maria Antonia Martins da Silva (2011). Para exemplificar, será apresentada uma sequência de três páginas duplas (figura 10, 11 e 12, respectivamente). Na primeira página dupla, o texto informa: "Rosita Maria Antonia Martins da Silva era um nome tão grande que pinicava. Que quase empurrava para fora da página!". O leitor só vai entender completamente o que quer dizer a frase "empurrar para fora da página", ao olhar para ilustração. É como se a personagem estivesse sendo empurrada, literalmente, para fora do livro por causa do tamanho do próprio nome. 
Figura 10- Páginas 4 e 5 do livro Rosita Maria Antonia Martins da Silva. Fonte: Arquivo pessoal.

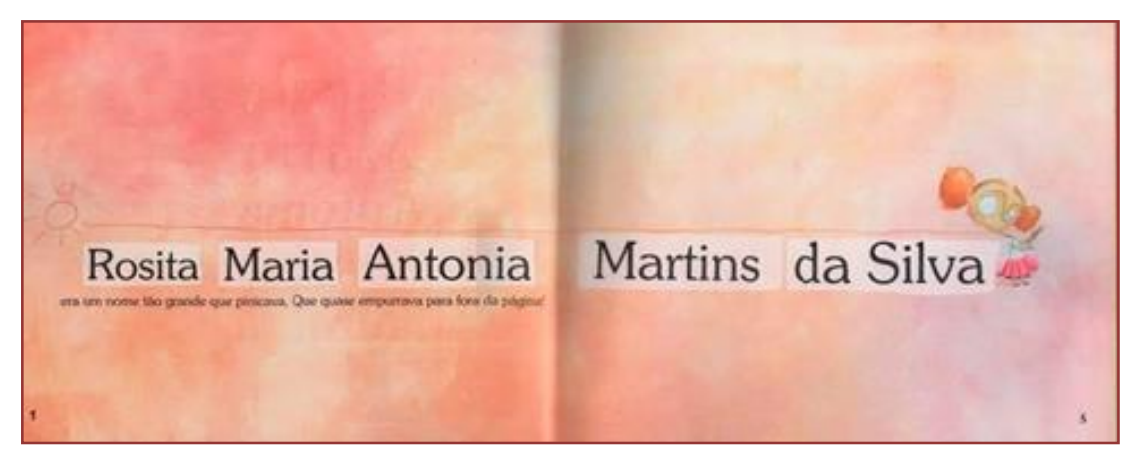

Na segunda dupla (figura 11), o texto informa "Rosi. Ela gostava mais. Sobrava até espaço para fazer o que bem quisesse...". Mais uma vez, o sentido vai ser completado pela visão da imagem da página que mostra que o espaço a que o texto está se referindo é a própria página dupla.

Figura 11- Páginas 6 e 7 do livro Rosita Maria Antonia Martins da Silva.

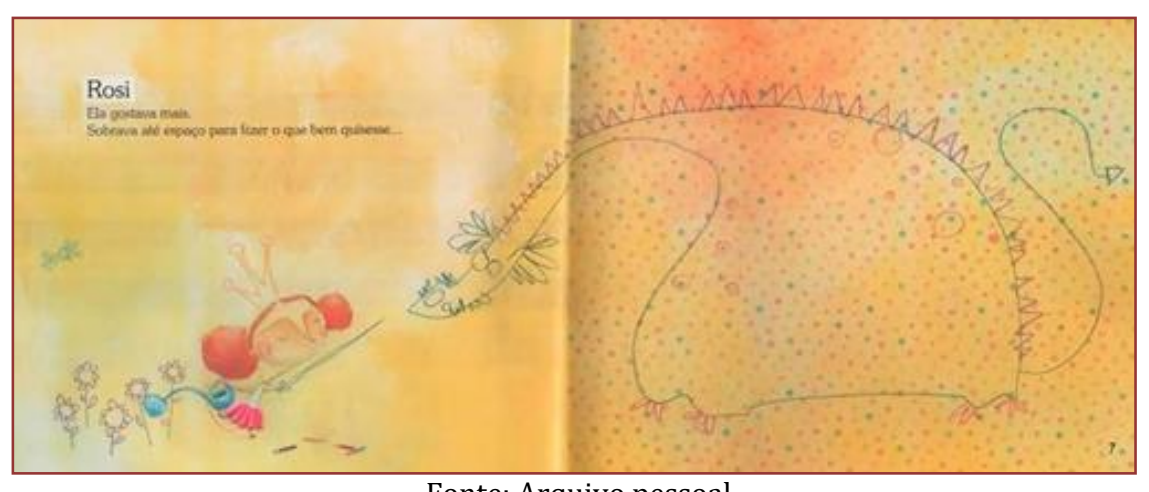

Fonte: Arquivo pessoal.

Então, o sentido se completa, acrescentando um tom cômico. Na terceira página dupla (figura 12) lê-se: "Mas nada mudava o fato de que ela se chamava Rosita Maria Antonia Martins da Silva!". Aqui, é como se os desejos da personagem de apenas se chamar Rosi e de desenhar no restante da página fosse esmagado pela realidade do tamanho do nome e, novamente, ela é quase jogada para fora da página.

Figura 12 - Páginas 8 e 9 do livro Rosita Maria Antonia Martins da Silva.

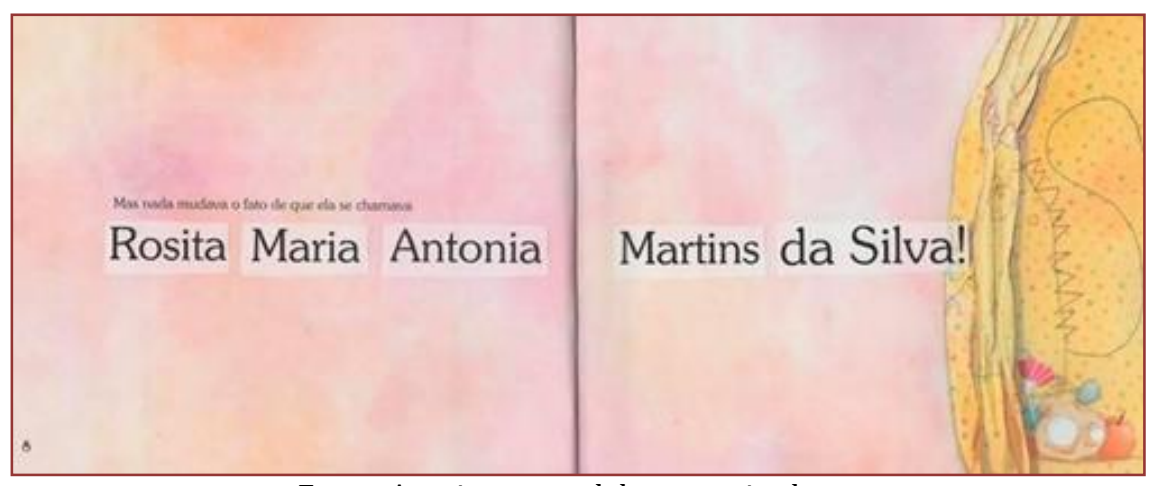

Fonte: Arquivo pessoal dos pesquisadores. 
Nesse exemplo, é perceptível a íntima relação entre texto e imagem, ambos se articulando e produzindo sentido no processo de compreensão, em que o humor é acrescentado pelo jogo lúdico com a ilustração. Esse caso torna evidente a exigência da leitura tanto da linguagem verbal quanto da visual, mostrando a vitalidade da ilustração como componente ativo da semântica textual.

No livro $O$ sonho que brotou (2010) encontra-se também a função de revelação (figura 13) que, segundo Linden (2011, p. 123) é quando "uma das instâncias pode dar sentido à outra. [...] 0 aporte do texto ou da imagem pode assim se revelar indispensável para a compreensão um do outro que, sem sua contraparte, permaneceria obscuro".

Figura 13 - Página dupla do livro 0 sonho que brotou

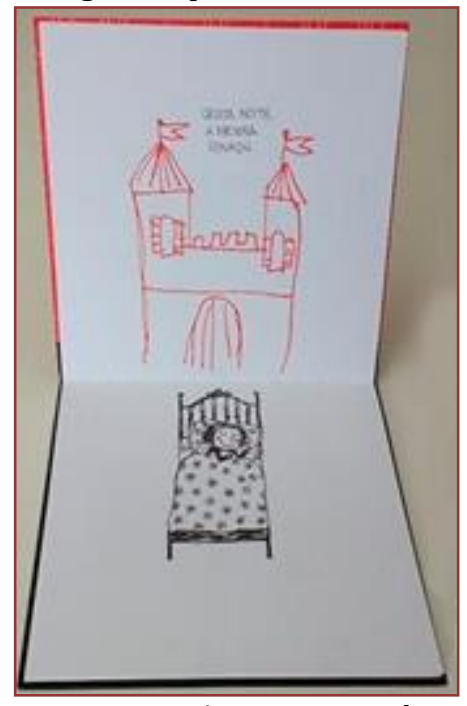

Fonte: Arquivo pessoal.

Nesse caso, enquanto o texto apenas afirma "Certa noite a menina sonhou", a imagem mostra o sonho que ela teve. Em outras palavras, a imagem revela o que o texto não diz, sendo essa revelação de suma importância para se entender a história.

\section{FONTE TIPOGRÁFICA}

Uma das grandes preocupações da tipografia é a legibilidade do texto, principalmente quando o público alvo é o leitor iniciante. De acordo com Lourenço (2011, p. 20), “o ato de ler é um dos aspectos mais importantes quando se trata do assunto tipografia. E este se torna mais importante quando quem está lendo é uma criança". É possível perceber (figura 14) essa preocupação na fonte tipográfica do livro $O$ sonho que brotou (2010).

Figura 14 - Tipografia do livro 0 sonho que brotou

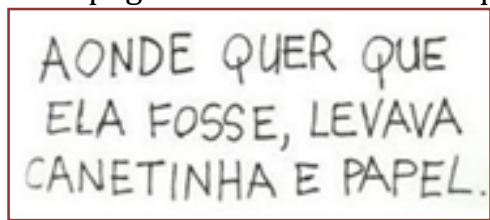

Fonte: Arquivo pessoal.

Nesse caso, a tipografia adotada é considerada excelente para leitores iniciantes, pois apresenta ótimo espacejamento entrelinha, entreletras e entrepalavras, além de apresentar letras maiúsculas, evitando confusão na leitura. Fontes com essas características facilitam a leitura para esses leitores.

Outra característica é que as frases aparecem diagramadas diferentes em cada página a depender da mensagem. É perceptível que a forma em que elas estão dispostas sugerem diferentes significados. No livro Cabelo doido (2010) encontram-se exemplos desse tipo (figura 15 e 16). 
Figura 15 - Páginas 16 e 17 do livro Cabelo doido.

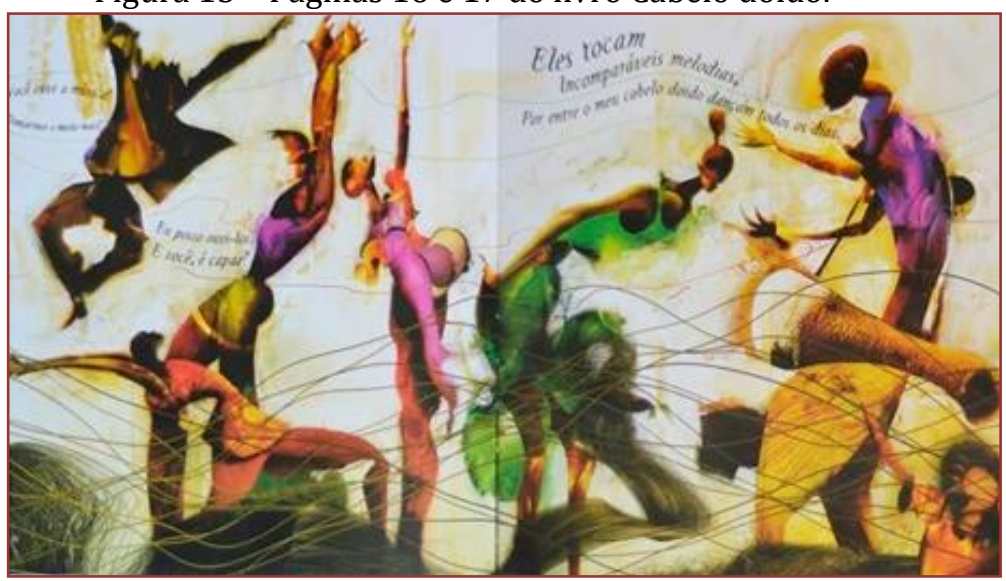

Fonte: Arquivo pessoal.

Figura 16 - Página 23 do livro Cabelo doido.

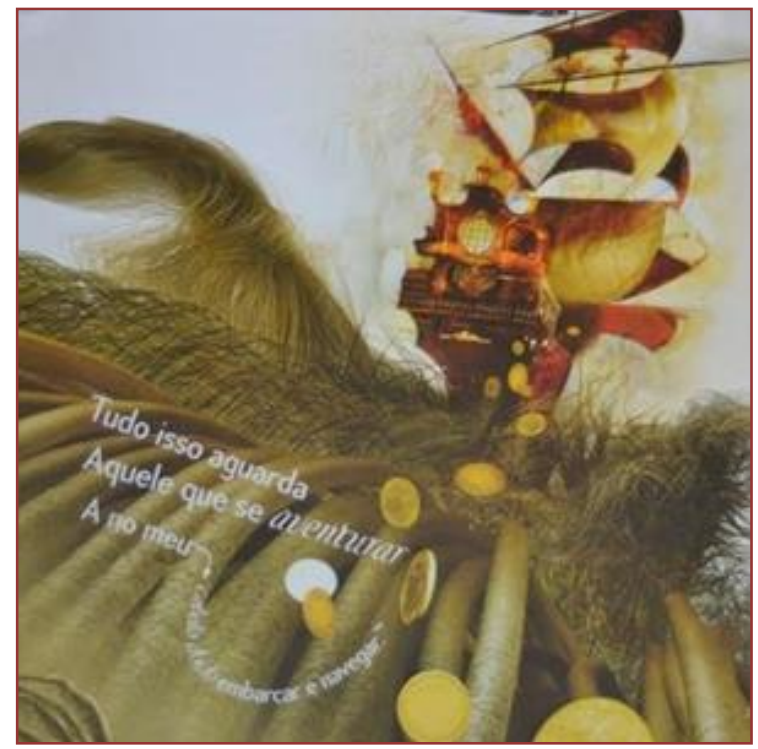

Fonte: Arquivo pessoal.

Nessas páginas, as frases que se referem a dançarinos e músicos lembram movimento. Outro caso é que a forma como a frase "Tudo isso aguarda /Aquele que se aventurar/ no meu cabelo doido embarcar e navegar" está diagramada de formar a lembrar o movimento de navios em ondas do mar. Esses exemplos trazem significação ao texto reafirmando a dinâmica e possibilidades semânticas que a tipografia pode agregar.

No caso do livro Rosita Maria Antonia Martins da Silva (2011), a tipografia utilizada é como de palavras que tivessem sido recortadas de revistas (figura 17), sugerindo que o livro trata de uma criança que está aprendendo seu nome. Retoma também atividades que muitas vezes são feitas nas escolas para aqueles que estão começando a escrever o nome. Em um dado momento, esses recortes, ao mesmo tempo em que são textos, são também imagem. 
Figura 17 - Páginas 24 e 25 do livro Rosita Maria Antonia Martins da Silva.

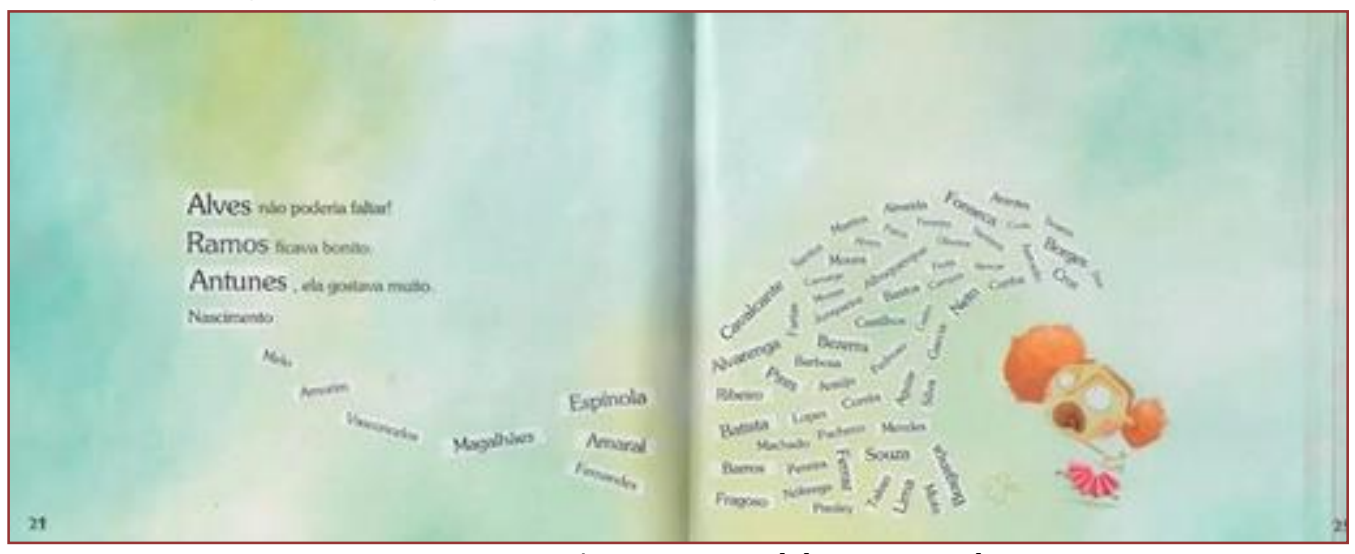

Fonte: Arquivo pessoal dos pesquisadores.

Nesse exemplo, é como se "a palavra se tornasse imagem e a imagem se tornasse palavra" (LINDEN, 2011, p. 92). Todos esses exemplos confirmam que "a tipografia é muito usada para converter significado. 0 texto transmite a mensagem por meio do alfabeto, mas além disso, pode através do efeito visual criar significados simbólicos da mesma forma que a imagem" (LOURENÇO, 2011, p. 129).

$\mathrm{Na}$ análise da tipografia foi ainda possível perceber que a fonte tipográfica pode ser grande aliada na leitura oral da palavra, de uma narrativa, pois ela sugere graficamente a prosódia possível ao texto. A voz do texto pode ser realizada tomando-se como referência as sugestões imagéticas propostas pelas ilustrações, como no caso de "Aquele que se aventurar no meu cabelo doido embarcar e navegar" (GAIMAN, 2010, p. 23), em que as letras em disposição curvilínea na página lembram o movimento de ondas, o que poderá levar a leitura oral a imitar esse balanço na voz. A tipografia em constante variação auxilia, sugerindo aparte que deve ser lida de maneira mais enfática, mais devagar, mais agitada, mais alta e mais serena. Esse aproveitamento da imagem no fraseado prosódico do texto é mais um recurso a que o mediador pode recorrer para favorecer a compreensão leitora de jovens aprendizes.

\section{CONSIDERAÇÕES FINAIS}

Uma das grandes responsabilidades da escola é formar leitores que leiam o mundo criticamente, pois é preciso, primeiramente, ler os livros para depois ler a vida. A Literatura Infantil é arte e nela se encontra diversão, mas, sobretudo, é uma fonte de aprendizagem e conhecimento, constituindo-se em um importante instrumento de trabalho dos professores para o ensino da leitura, exigindo desse profissional o conhecimento desse objeto.

Além de explorar os aspectos verbais de uma obra, o mediador pode estimular e ensinar a turma a ler os aspectos plásticos que o livro traz. Ler imagens também se ensina. Com a exploração do projeto gráfico, a leitura ficará mais rica em detalhes e irá contribuir para que eles apreendam mais do texto, por isso que se ressalta neste trabalho a relevância do docente conhecer tais aspectos.

Em suma, é preciso entender que o design define as dimensões de todo livro e sua forma pode oferecer pistas sobre o texto; que a boa ilustração é aquela que complementa o texto e não apenas reafirma o que está dito; que a ilustração complementa e estabelece relação com o texto, ampliando a forma da leitura e a exploração dos livros, e, por fim, a fonte tipográfica deve ser legível, e que a forma como está diagramada no livro pode contribuir com a prosódia do professor, na hora da leitura em voz alta.

Esta é a importância da pesquisa em questão: fazer esses conhecimentos se firmarem na área da educação, mais especificamente na formação dos pedagogos, que são os profissionais que introduzem as crianças no mundo da leitura, pois o livro é suporte fundamental para formação de leitores. 


\section{REFERÊNCIAS}

[1] Amarilha, Marly. Estão mortas as fadas? Literatura infantil e prática pedagógica. 8. ed. Petrópolis-RJ: Vozes, 2012.

[2] Camargo, Luís. Ilustração e projeto gráfico. In: . Ilustração do Livro Infantil. Rio de Janeiro: Sindicato Nacional dos Editores do Rio de Janeiro, 1995. p. 16-39.

[3] Faria, Maria Alice. Como usar a literatura infantil na sala de aula. São Paulo: Contexto, 2004.

[4] Gaiman, Neil. Cabelo doido; Ilustrações [de] Dave Mckean. Rio de Janeiro: Rocco Pequenos Leitores, 2010.

[5] Hendel, Richard. O design do livro. São Paulo: Ateliê Editorial, 2006.

[6] Joly, Martine. Introdução à análise da imagem. 14ª̣ ed.- Campinas, SP: Papirus, 2012. - (Série Ofício de Arte e Forma).

[7] Linden, Sophie Van der. Para ler o livro ilustrado. São Paulo: Cosac Naify, 2011.

[8] Lourenço, Daniel Alvares. Tipografia para livro de literatura infantil: desenvolvimento de um guia com recomendações tipográficas para designers. 2011. 230 f. (Dissertação de mestrado) - Curitiba, 2011.

[9] Moriconi, Renato. 0 sonho que brotou. - São Paulo: DCL, 2010.

[10] Moraes, Odilon. O projeto gráfico do livro infantil e juvenil. In: Oliveira, Ieda de (org). 0 que é qualidade em ilustração no livro infantil e juvenil: com a palavra o ilustrador. - São Paulo: DCL, 2008.

[11] Roldán, Gustavo. Como reconhecer um monstro. - São Paulo: Frase e Efeito, 2011. Terra, Ana. Rosita Maria Antona Martins da Silva. São Paulo: Lafonte, 2011.

[12] Ventura, Antônio. Recuperar a palavra para decodificar as imagens. In: Amarilha, Marly (Org.). Educação e Leitura: novas linguagens, novos leitores. Campinas-SP: Mercado de Letras, 2012.

[13] Yunes, Eliana. A provocação que a literatura faz ao leitor. IN: Amarilha, Marly (org.).

[14] Educação e leitura: redes de sentidos. - Brasília: Liber livro, 2010. 


\section{Capítulo 18}

\section{A literacia na perspectiva dos planos nacionais de leitura no Brasil e em Portugal}

\section{Maria Emília Pinto Vilarinho Rodrigues Barros Zão Patricia Veronica Nascimento Dias Fernandes}

Resumo: A leitura é essencial para se alcançar as competências mínimas para atender as demandas do mundo atual. Assim a leitura tornou-se preocupação para os países se desenvolverem economicamente, e dessa forma, passa a fazer parte de políticas públicas, sejam no bojo da educação formal através de sistemas educativos, sendo avaliados, por instrumentos nacionais e internacionais, bem como na educação não formal por meio de ações voltadas para estimular a leitura em leitores potenciais. Este estudo teve como objetivo identificar as semelhanças e diferenças entre os planos nacionais de leitura do Brasil e de Portugal, ao nível da formulação política, governação e implementação. Para atender aos objetivos da investigação, foi desenvolvido um estudo de casos múltiplos cujo levantamento dos dados se deu através de pesquisa documental e de entrevistas semiestruturadas, realizadas a coordenadores dos Planos, bibliotecários municipais e professores responsáveis por bibliotecas escolares dos dois países. De acordo os dados recolhidos é possível afirmar que existe a influência de organismos internacionais para o desenvolvimento de políticas públicas de leitura nos dois países. No Brasil, destaca-se a influência do Centro Regional para el Fomento del Libro en América Latina, e em Portugal, a Organização para a Cooperação e Desenvolvimento Económico, através do Programa Internacional de Avaliação de Alunos. O estudo concluiu que os Planos apresentam algumas semelhanças na sua formulação política e na governação e dessemelhanças aos níveis dos destinatários, das práticas implementadas e influência dos interesses do mercado livreiro.

Palavras-Chave: Política Educativa. Organizações Internacionais, Políticas Públicas de Leitura. Planos Nacionais de Leitura - Brasil e Portugal. 


\section{INTRODUÇÃO}

A leitura é essencial para se alcançar as competências mínimas necessárias para atender as demandas do mundo atual, por ser ela, uma atividade fundamental que assegura o desenvolvimento da imaginação e da criatividade humana, além da sua importância para a aprendizagem e do conhecimento da linguagem no cultivo da capacidade de expressar as ideias e desenvolver o pensamento crítico, e "como forma de conhecimento, interpretação e compreensão do mundo e do ser humano, é imprescindível uma articulação contínua, intensa e harmoniosa" (Garcez, 2009, p. 66).

Nesta perspectiva, inferimos que, para que exista uma sociedade leitora, ou seja, uma sociedade que tenha a efetiva participação dos cidadãos no processo democrático é preciso unir conforme destaca Freire (2004) "a leitura da palavra à leitura de mundo", pois, só através desta junção é possível as pessoas refletirem sobre a sua condição enquanto atores sociais e políticos.

Daí a necessidade do envolvimento de diferentes actores sociais, professores, bibliotecários, editores, especialistas, pesquisadores, de variados segmentos sociais, tais como a família, a escolas, associações, igrejas, meios de comunicação, entidades não governamentais e, claro, as instituições governamentais para a socialização do acesso à leitura. Embora, se reconheça o empenho na missão de formar leitores, Dias (2009, p. 14), chama atenção que, "a despeito dos bons resultados de algumas ações em torno do incentivo à leitura e ao contato com o universo dos livros, muito resta a ser feito".

No entanto, há evidencias ${ }^{33}$ que o desenvolvimento de tais habilidades não correspondem com o desejado, daí a importância em criar políticas de incentivo à leitura, atividade de alta complexidade, exige mais que soluções quantitativas, e os efeitos que dele podem advir - desenvolvimento social, participação cidadã e formação humana - são, numericamente, incomensuráveis, ou seja, criar bibliotecas e estimular o mercado editorial de nada adianta se não existir pessoas capazes de atender esta demanda leitora.

Nos últimos anos tanto no Brasil quanto em Portugal foram desenvolvidas políticas públicas de incentivo à leitura, a fim de, em Portugal melhorar os índices de literacias, e no Brasil de promover mudanças culturais, com o intuito de formar uma sociedade mais crítica, consciente de seus direitos e deveres, para uma efetiva participação cidadã. Em ambos os casos procurou a partir de políticas públicas de estímulo à leitura melhorar o desempenho dos leitores através dos planos nacionais de leitura.

Embora se trate de dois países distantes geograficamente eles se solidarizam pelos vínculos culturais, histórico, econômico e político, em destaque a ligação direta exercida por Portugal no que se refere a formação do povo brasileiro. Assim, este estudo se apoia na questão de partida das semelhanças entre as estratégias desenvolvidas para a implementação das políticas públicas de estimulo à leitura, e, conseguintemente para a formação de uma sociedade leitora tendo como pano de fundo uma "agenda globalmente estruturada" (Dale, 2004).

De objetivo descritivo, este estudo visa o delineamento das características do fenômeno observado, e desta forma descobrir a sua frequência de ocorrência, sua relação e sua conexão com outros fenômenos, descortinando assim os pontos em comum e as dessemelhanças entre os Planos. A fim de se alcançar os resultados pleiteados no estudo, optou-se em utilizar como instrumento de coleta de dados a entrevista semiestruturada, seu uso se justifica, porque os dados por ela fornecidos são sucessíveis de classificação, informação imprescindível para a disposição dos resultados.

\section{INFLUÊNCIAS INTERNACIONAIS E LOCAIS NAS POLÍTICAS DE LEITURA}

Na atualidade, vem sendo cada vez mais comum os países aderirem mesmo de forma não oficial a um novo modelo de governação, que segundo Costa (2011) "o Estado é tão só um ator a mais, e não apenas único, a projetar e dar forma à política educativa" denominada de 'governança', a qual apresenta em sua estrutura de governo a não linearidade, ou seja, não há uma estrutura hierarquizada, cujos atores não pertencem aquele país, mas tem grande influência na implementação de políticas públicas e de regulação das mesmas.

Para Antunes (2007) os modelos, as orientações, os programas tomam forma e emanam de organizações internacionais e por sua vez, as ações públicas e coletivas ganham força através de movimentos, alianças, campanhas que envolvem as opiniões públicas e populações de âmbito global, onde a sociedade contemporânea se encontra literalmente envolvida no processo de globalização. 
Para Charlot (2007), a globalização, trouxe de fato benefícios para alguns países, mas não correspondeu aos países mais pobres e às vezes, prejudicou-os. Por conseguinte, a globalização é entendida, segundo Giddens (1991) como sendo a intensificação das relações sociais de escala mundial, relações que ligam localidades distantes de tal maneira que as ocorrências locais são moldadas por acontecimentos que se dão a muitos quilômetros de distância e vice-versa. Nesta perspectiva Antunes (2005) chama atenção para a globalização e a europeização, ao afirmar que a União Europeia tende a ampliar e aprofundar a sua capacidade de atuação e influência, redesenhando as fronteiras da sua ação em termos quer de áreas políticas quer de limites territoriais.

Destarte os estudos publicados das organizações internacionais são decisivos na normalização de políticas educativas nacionais, determinando uma agenda que especifica as prioridades e o modo como os problemas devem ser solucionados. Importante destacar as semelhanças dos nomes e objetivos dos dois planos de promoção à leitura desenvolvida no Brasil - Plano Nacional do Livro e da Leitura (PNLL) e em Portugal - Plano Nacional de Leitura (PNL), o que remete a um questionamento de Lima (2011):

mas, por outro lado, como seria possível, hoje, estudar as políticas educacionais de um país, região ou estado, ou mesmo município, sem considerar a influência de orientações políticas de circulação internacional, os grandes consensos estabelecidos, o senso comum educacional e os conceitos da moda, quase universalmente disseminados, a doxa promovida e partilhada através dos grandes meios de comunicação social? (Lima, 2011, p. 5).

Além das influências internacionais sofridas pelo Estado no que se refere a conduzir suas políticas educativas, apresentadas anteriormente, há de se apontar as das influências locais, muitas vezes exercidas pelos sindicatos, partidos, coletivos sociais, Organizações Não Governamentais - ONGs, dentre outras forças que impulsionam as decisões políticas, as quais, para serem compreendidas é necessário entender a relação entre sociedade civil e Estado, para a consolidação da democracia bem como compreender as determinações globais e as particularidades locais que incidem na implementação das políticas educativas, logo, as políticas públicas refletem as relações de poder e os conflitos existentes na sua definição, como também a própria representação que a sociedade apresenta no contexto histórico a que estas surgem. (Santos, 2012, p. 12).

Portanto, as arenas de conflitos e de reivindicações vão se modificando à proporção que a sociedade também nomeia as suas representações de interesses, nesta perspectiva Scherer-Warren (2006, p.10), esclarece que "a sociedade civil está preferencialmente relacionada à esfera da defesa da cidadania e suas respectivas formas de organização em torno de interesses públicos e valores, incluindo-se o de gratuidade/altruísmo", haja vista, o conceito de cidadania não permanecer inalterado na história tampouco na sociedade, o que leva Cabral (2003) a enfatizar que há três tipos ou categorias de cidadania, a saber a cidadania civil - a qual refere-se a liberdade natural; a cidadania social - corresponde a igualdade democrática; e por fim a cidadania política que diz respeito a igualdade liberal, assim para efeito desse estudo, entenderemos como cidadania como o conjunto dos direitos e deveres civis, sociais e políticos.

\section{PLANOS NACIONAIS DE LEITURA NO BRASIL/PNLL E EM PORTUGAL/PNL}

Ao se falar em leitura, temos também que falar de leitores, de livros, de acervos, de bibliotecas, de literatura e principalmente do acesso, o que implica falarmos de cidadania, ou seja, a plena prática que o indivíduo faz dos seus direitos e deveres políticos e civis. Assim, em 2006 é lançado o Plano Nacional do Livro e Leitura, que tem como objetivo principal transformar o Brasil num país de leitores. Pensado em proporcionar o aprendizado da leitura e da escrita tanto pela via escolar, a partir da distribuição de materiais didáticos quanto em disponibilizar instrumentos para a prática social e para atender está visão de leitura em sentido amplo são requeridos dezoito objetivos para serem alcançados no curto, médio e longo prazo.

O Plano adotou eixos de ação, onde os objetivos acima apresentados se encontram distribuídos, esses eixos servem como uma espécie de baliza para que as mais variadas instituições e entidades da sociedade planejem e implementem suas ações, concentrando o foco nas prioridades do setor e não dispersando recursos de qualquer natureza" (Marques Neto, 2010, p. 51). Desta forma, foram instituídos quatro eixos de ação, com vista a objetivar a Democratização do acesso; Fomento à leitura e à formação de mediadores, Valorização da leitura e da comunicação, Desenvolvimento da economia do livro. 
Com base no que foi apresentado nos quatro eixos de ação, pode-se inferir que o PNLL, teve a preocupação em envolver todos os fatores que implicam na questão da leitura, do livro, do leitor e da literatura dando atenção a todas as transversalidades que o tema exige.

Nos países da União Europeia, a promoção da leitura tem assumido significativa relevância, que de acordo Ferreira (2009), muitas políticas têm vindo a generalizar-se em diversos países, reconhecendo a importância das competências da leitura para o desenvolvimento de cidadãos de pleno direito em sociedades democráticas.

Neste aspecto, Portugal com base em estudos nacionais (ex. Estudo Nacional de Literacia) e internacionais (ex. PISA, IALS ${ }^{34}$ ) se localizava numa situação de desvantagem em literacia em relação aos demais países europeus, conforme destaca Grancho (2013, p. 11), "há pouco mais de uma década, os vários estudos nacionais e internacionais tornaram evidentes os baixos níveis de literacia dos jovens portugueses, designadamente em leitura, situando-os num patamar significativamente inferior à média europeia."

O Plano Nacional de Leitura surge com a missão de elevar o índice de literacia dos portugueses, conforme destaca Costa et al (2011, p. 17) "o PNL nasceu do reconhecimento, pelos decisores políticos, em implementar políticas que busquem aumentar o índice de literacia da população portuguesa, haja vista, as estatísticas apontarem um retrato confrangedor no que se refere aos altos níveis de iliteracia e a falta de interesse dos portugueses pela leitura, o que, segundo Rodrigues (2014, p. 15) "são em regra justificados pela tardia universalização da escolaridade da população e pelas taxas de escolarização cronicamente baixas".

O Plano apresenta uma estratégia faseada, a fim de abranger os diferentes sectores da população, assim para cada fase de cinco anos é estabelecido o público a quem será destinado às ações. Essas fases são estabelecidas através de estudos tecnicamente fundamentados capazes de permitir a operacionalização das metas, além de possibilitar a criação de instrumentos de avaliação, o monitoramento dos programas e também a avaliação da eficácia de cada ação.

Desta forma, o PNL é lançado alicerçado nos seguintes objetivos norteadores para a formação de uma sociedade portuguesa alfabetizada e emancipada:

A fim de alcançar os objetivos, o Plano apresenta quatro programas centrais ou nucleares, a saber: i) Promoção da leitura diária a partir dos Jardins-de-infância e nas escolas de primeiro e segundo ciclos nas salas de aula; ii) Promoção da leitura no contexto familiar; iii) Promoção da leitura em bibliotecas públicas e noutros ambientes sociais, e iv) Lançamento de campanhas que busquem sensibilizar a opinião pública, de programas de informação e de recreação voltados para o livro e a leitura por meio dos órgãos de comunicação social

Desta forma, foram criados projetos de âmbitos e duração diversificados dirigidos aos mais variados contextos sociais, em destaque os desenvolvidos pelas bibliotecas públicas e outros parceiros (Rodrigues, 2014). É perceptível a importância que a leitura ocupa na sociedade em Portugal e o esforço em transformar o país numa nação que compreende a leitura na perspectiva formativa e reflexiva, o que evidencia o esforço do governo em implementar políticas públicas de promoção a leitura.

\section{PONTOS DE CONVERGÊNCIAS E DIVERGÊNCIAS ENTRE O PNLL E O PNL.}

Assim, foi possível identifica os seguintes aspectos de semelhanças entre os planos:

A Influência de organismos internacionais na tomada de decisões políticas - o Plano português teve influência da OCDE através do Programa para Avaliação Internacional de Estudantes (PISA). No Brasil e influência foi feita pela OEI, e o CERLALC.

As limitações nos recursos financeiros e humanos - são apontadas como um dos grandes problemas para a operacionalização dos planos.

A existência das mesmas finalidades entre os planos - ambos os países objetivam com seus Planos de leitura a formação de uma sociedade leitora.

Os valores simbólicos atribuídos à leitura - a relação estabelecida entre o sucesso acadêmico e a leitura é confirmada pelos entrevistados, bem como a relação entre leitura e a cultura.

\footnotetext{
${ }^{34}$ International Adult Literacy Survey [Pesquisa Internacional de Alfabetização de Adultos]
} 
Parcerias - foi identificada a presença de parcerias nos dois Planos investigados, tanto da iniciativa pública, como do terceiro setor da iniciativa privada.

No que se refere aos aspectos em que os planos diferem, foi possível identificar:

o período de vigência - o Plano português foi desenvolvido, instituído para ser executado no prazo de dez anos, enquanto que o Plano do Brasil não há data de término, haja vista a própria complexidade do plano brasileiro.

Eixo de intervenção - em Portugal o Plano é preferencialmente direcionado para a população escolar, com ênfase nas bibliotecas escolares, as quais constituem como recurso básico do processo educativo. Enquanto que no Brasil é direcionado para toda a população.

Avaliação e Monitoramento - apesar de constar no desenho dos dois Planos a avaliação e monitoramento das suas ações, na prática a experiência dos dois países revela diferenças de atuação. 0 Plano português é periodicamente avaliado. No Brasil, embora esteja registrado nos princípios norteadores do Plano, ainda não foi avaliado.

Disponibilidade de Orçamento - o Plano português conta com dois orçamentos, um que é destinado às escolas e outro para demais atividades de incentivo à leitura. No Brasil não há um orçamento especifico para o Plano.

Participação da sociedade civil e voluntariado - o Brasil conta com a participação da sociedade civil, não apenas como parceiro, mas principalmente para a formulação dos planos estaduais e municipais, e também com o trabalho voluntariado das pessoas que participam na implementação e desenvolvimento das ações de estimulo à leitura. Em Portugal a sociedade civil atua como parceira.

\section{CONSIDERAÇÕES FINAIS}

De acordo o caminho percorrido nesta investigação, infere-se que os processos de letramento exigem iniciativas que venham atenuar a realidade das pessoas que não tiveram acesso ou tiveram o acesso interrompido a literacia.

Deve-se levar em consideração que o PNLL tem como foco toda a população, mas as pessoas que deveriam ser privilegiadas nas políticas públicas de leitura acabaram ficando dispersa, o que comprometeu o êxito do plano no Brasil, pois o público foi identificado, no entanto não foram localizados, para poderem ser monitorados e devidamente avaliados o que é o inverso no caso Português, onde o PNL delimitou seu público alvo, identificou-os e localizou-os e a partir daí traçou as ações de leitura, monitorou e avaliou.

A forma como foi formulado o PNL - no que se refere seus objetivos, público identificado, ações estabelecidas e profissionais e instituições envolvidos para o desenvolvimento do plano assegurou o êxito do plano haja vista, que ele foi criado para dar uma resposta às baixas notas obtidas pelo país na avaliação do PISA e conseguiu melhorar no ranking, se em 2000 obteve a média 403, em 2012 ficou com 488, e dessa forma se aproximou mais da média estabelecida pela Organização.

Tal desempenho deve-se aos esforços de todos os envolvidos, desde o governo que formulou, implementou e submete à avaliação o plano aos demais profissionais, professores, bibliotecários, professores bibliotecários, diretores, alunos e pais. Portanto, podemos concluir que em Portugal estabeleceu-se uma verdadeira rede onde os nós relacionam-se com as instituições tradicionalmente responsáveis pela gestão, disseminação da informação e do estímulo à leitura e o conhecimentos além dos nós que interligam profissionais e práticas que possibilitam a efetivação de ambientes e indivíduos a desenvolverem o interesse à leitura.

\section{REFERÊNCIAS}

[1] Antunes, F. Dimensões Européias da Educação: sentidos, perplexidades e desafios. In Atas do VIII Congresso Galaico-Português de Psicopedagogia. Ed. Centro de Investigação em Educação (Cied), Universidade do Minho (pp. 1343-1359). 2005, September.

[2] ___. A nova ordem educativa mundial e a União Europeia: a formação de professores dos princípios comuns ao ângulo português. Perspectiva, 25(2), 425-468. 2007 
[3] Cabral, Manuel Villaverde. O exercício da cidadania política em perspectiva histórica (Portugal e Brasil). Revista Brasileira de Ciências Sociais, 18(51), 31-60, 2003 Acesso em Janeiro 21, 2016, em, http://www.scielo.br/scielo.php?script=sci_arttext\&pid=S0102-69092003000100005\&lng=en\&tlng=pt.

[4] Charlot, B. (2007). Educação e globalização: uma tentativa de colocar ordem no debate. Sísifo: revista de ciências da educação da Universidade de Lisboa, n. 4, p.129-136, 2007.

[5] Costa, E. (2011). O 'Programme for International Student Assessment' (PISA) como instrumento de regulação. 2011. Acedido em Julho 04, 2014 em http://repositorio.ul.pt/handle/10451/3002.

[6] Costa, F. C. (Coord.), Coelho, A. R., Ávila, P. \& Pegado, E. Avaliação do Plano Nacional de Leitura: Os primeiros cinco anos. Centro de Investigação e Estudos de Sociologia, Instituto Universitário de Lisboa. 111p. 2011.

[7] Dale, R. Construir a Europa através de um espaço europeu de educação. Revista Lusófona de Educação, Lisboa, n. 11, p. 13-30, 1ํㅗ. sem. 2004.

[8] Dias, A. Apontamentos sobre leitura, literatura e formação do leitor. In. Programa Nacional de Incentivo à Leitura. Cursos da Casa da Leitura, 3: prácticas leitoras. Rio de Janeiro: Biblioteca Nacional. 11-35. 2009.

[9] Ferreira, S. C. T. O Plano Nacional de Leitura e a Promoção de Hábitos de Leitura nas Escolas do 1o Ciclo do Ensino Básico: Um Estudo de Caso. Dissertação de Mestrado, Departamento de Ciências da Educação e do Patrimônio, Universidade Portucalense Infante D. Henrique, Porto, Portugal. 2009.

[10] Freire, P. A importância do ato de ler: em três artigos que se completam. (50ํㅡㄹ.) São Paulo: Cortez. (Coleção questões da nossa época; 13). 2004.

[11] Garcez, L. H. A construção social da leitura. In Programa Nacional de Incentivo a Leitura. Cursos da Casa da Leitura, 2. Rio de Janeiro: Biblioteca Nacional. pp. 65-77. 2009.

[12] Giddens, A. (1991). As conseqüências da modernidade. São Paulo: UNESP.

[13] Grancho, J. Mensagem do senhor Secretário de Estado do ensino básico e secundário. In. Ler + Plano Nacional de Leitura: Relatório de atividades 2012 - 2013 (2ª fase - 2º ano), Lisboa: Ministério da Educação, Portugal. 2013.

[14] Lima, L. C. Políticas educacionais, organização escolar e trabalho dos professores. Educação: Teoria e Práctica, 11 (28), 1-18. 2011.

[15] Marques Neto, J. C. (Org.). Pnll: Textos e história. São Paulo: Cultura Acadêmica Editora, 2010

[16] Rodrigues, M. L. (Org.). 40 anos de políticas de educação em Portugal: volume II conhecimento, atores e recursos. Coimbra, Almedina. 620p. 2014.

[17] Santos, A. P. Do falecido INL ao nascimento do PNLL, finalidades semelhantes, resultados iguais? XVIII Congresso de Leitura do Brasil. Campinas, SP: FE/Unicamp: Alb. 2012. Acesso em maio 4, 2015, em http://alb.com.br/sites/default/files/18-cole-caderno-de-resumos-final.pdf.

[18] Scherer-Warren, I. Das mobilizacções às redes de movimentos sociais. Sociedade e Estado, Brasília. 21(1), 109-130, 2006. Acesso em Janeiro 09, 2016 em http://www.scielo.br/pdf/rsocp/v16s0/a04v16s0.pdf. 


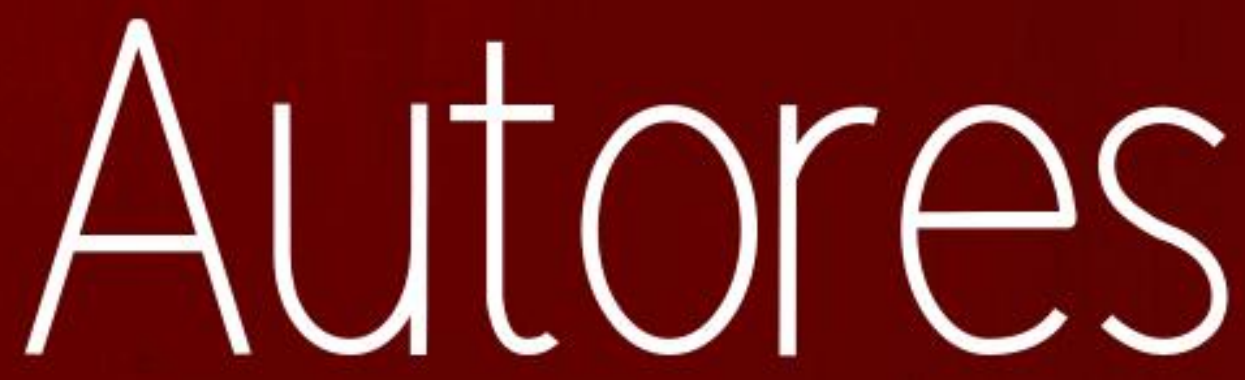




\section{AIRTON CARLOS BATISTELA}

Possui licenciatura em Filosofia - Faculdades Integradas de Palmas (1991), Mestrado em Educação pela Pontifícia Universidade Católica do Rio Grande do Sul (1996) e Doutorado em Educação pela Pontifícia Universidade Católica do Paraná- PUCPR (2011). Tem experiência na área de Filosofia, com ênfase em Ética, Filosofia da Ciência, História da Ciência, Sociologia da Educação, Fundamentos da Educação e Educação do Campo. Atua principalmente nos seguintes temas: filosofia, educação, Filosofia da Ciência e História da Ciência. Atua nos Grupos de Estudos e Pesquisas em História, Sociedade e Educação, HISTEDBR e Núcleo de Estudos e Pesquisas sobre Ensino de Filosofia e Educação Filosófica - Regional Planalto Catarinense, pesquisador e vice-líder. Participa das seguintes Linhas de Pesquisa: Ensino de Filosofia, História e Políticas da Educação e Políticas e Processos Formativos em Educação.

\section{ANDREZZA M. B. DO N. TAVAVES}

Doutora e Mestre em Ciências da Educação pela UFRN. Licenciada em Pedagogia, bacharelanda em Jornalismo e Pós-Graduada em Psicopedagogia Clínica. Professora do Instituto Federal de Educação, Ciência e Tecnologia do Rio Grande do Norte (IFRN), desde 2009, onde realiza atividades de ensino, pesquisa e extensão. Professora na oferta de educação superior, no Programa de Pós-Graduação Acadêmica (PPGEP/IFRN) e no Mestrado Profissional em Ensino de Física (MNPEF/IFRN). Coordenadora Institucional do Programa Pibid/IFRN financiado pela agência de fomento CAPES, no período de 2013 até 2018. Coordenadora Institucional do Programa Residência Pedagógica/IFRN financiado pela agência CAPES, desde 2019. Na Extensão, Coordena o Projeto "Diálogos do IFRN com o Capital Cultural", desde 2017. Na pesquisa, é membro do Grupo de Pesquisa vinculado ao CNPQ "Escola Contemporânea e Olhar Sociológico (ECOS)" onde realiza investigação no campo das ciências da educação junto a linha de pesquisa "Sociologia educacional e ação pedagógica", na UFRN. No Jornalismo, escreve e apresenta nos veículos de comunicação Potiguar Notícias e PNTV. As atividades profissionais realçam proximidade com os objetos: Formação de Professores, Educação Profissional, Educação Superior, Processos Cognitivos, Educação Escolar e Não-Escolar e Teorias da Aprendizagem e da Comunicação.

\section{ANDRIALEX WILLIAM DA SILVA}

Graduado em Pedagogia pela Universidade Federal do Rio Grande do Norte (UFRN). Atualmente metrando em Educação pelo Programa de Pós-Graduação em Educação da UFRN, na linha de Educação e Inclusão em Contextos Educacionais. Tem interesse na área de educação, com ênfase em Educação Especial/Educação Inclusiva, Formação Docente e Alfabetização.

\section{ANÍBAL SIMÕES FILHO}

Licenciado em Geografia pela Universidade estadual da Paraíba- UEPB Campus III; Membro dos Grupos de pesquisa: Centro de Estudos Agrários e do Trabalho - CEAT e Olhares Geográficos - Grupo de Pesquisa em Geografia Cultural e da Percepção. PósGraduando lato sensu em Geografia, Território e Planejamento Urbano, Rural e Ambiental, pela UEPB - CH/Campus III. 


\section{BERNADETE DE LOURDES FIGUEIREDO DE ALMEIDA}

Graduação em Serviço Social pela Universidade Federal da Paraíba (1971), mestrado em Serviço Social pela Universidade Federal da Paraíba (1984), doutorado em Serviço Social pela Pontifícia Universidade Católica de São Paulo (1990) e pós-doutorado pela PUC/SP (2004). É professora na categoria Titular do Departamento de Serviço Social em nível de Graduação e da Pós-Graduação em Serviço Social da Universidade Federal da Paraíba; Pesquisadora Nível 1-B do CNPq.

\section{CAMILA LUANA TEIXEIRA FREIRE E-}

Graduação em Serviço Social pela Universidade Federal da Paraíba (2017). Mestranda em Serviço Social pelo Programa de Pós Graduação em Serviço Social da Universidade Federal da Paraíba.

\section{CAROLINE STÉPHANIE CAMPOS ARIMATEIA MAGALHÃES}

Graduada em Psicologia pela Universidade Potiguar (2004) e Pedagogia pela Universidade Federal do Rio Grande do Norte (2008), Especialista em Gestão de Pessoas e Comportamento Organizacional pela Universidade Potiguar (2008) e Mestra em Educação Profissional pelo Instituto Federal de Educação, Ciência e Tecnologia do Rio Grande do Norte - IFRN (2016). Atualmente é Psicóloga do IFRN Campus Natal-Central e docente do Estado do Rio Grande do Norte.

\section{ELIARA ZAVIERUKA LEVINSKI}

Possui graduação em Pedagogia - L (1983), especialização em Fundamentos Metodológicos da Educação (1985) e em Alfabetização (1989) e mestrado em Educação (2000) pela Universidade de Passo Fundo (UPF) e doutorado em Educação pela Universidade Federal do Rio Grande do Sul (2008). Atualmente é professora titular da Universidade de Passo Fundo no curso de Pedagogia, integra o quadro docente dos cursos de pós-graduação lato sensu Supervisão Educacional, Políticas e Gestão da Educação e Psicopedagogia, coordena o curso de Especialização Políticas e Gestão da Educação e o projeto de extensão e de pesquisa Gestão da educação: o feito, o necessário e o possível. Foi diretora da Faculdade de Educação da UPF (julho de 2010 a julho de 2018). Realiza atividades de extensão universitária na área de formação de professores e de pesquisa na linha de políticas educacionais, é coordenadora institucional do Programa Nacional de Formação de Professores da Educação Básica (Parfor). Na trajetória profissional atuou como professora da rede estadual de ensino do RS, constituiu experiência em assessorias técnico-pedagógicas e em processos de gestão do ensino público. Aborda e publica, com mais ênfase, temáticas como: políticas e gestão da educação, formação de professores, projeto político-pedagógico e gestão democrática.

\section{EVERTON MARCO BATISTELA}

Filósofo (Unioeste, 1996), mestre e doutor em Sociologia (UFPR, 2009). Desde 2014 atua como professor no Curso de Educação do Campo na UTFPR - Campus Dois Vizinhos. Possui publicações relativas aos temas da Agroecologia, Educação do Campo, Desenvolvimento Rural, Agricultura Familiar, Racionalidade Ambiental e Sociologia Jurídica, dentre outras abordagens de caráter sociológico e filosófico. Desde 2000 tem experiência docente no ensino superior nas áreas de Sociologia e Filosofia, com ênfase em Sociologia da Educação, Filosofia da Educação, Educação do Campo, Educação Ambiental, Sociologia Jurídica, Ciência Política e Economia Política, dentre outros. 


\section{FAUSTO DOS SANTOS AMARAL FILHO}

Fausto dos Santos Amaral Filho é graduado em Filosofia pela PUCRS (1996), mestre em Filosofia pela PUCRS (1999) e doutor em Filosofia pela UFRJ (2005). Atualmente é professor-pesquisador do PPGED da UTP, linha de Pesquisa Políticas Públicas e Gestão da Educação. Atuando nos seguintes temas: Hermenêutica e Educação; crítica da Modernidade e Educação; Epistemologia da Educação. Líder do Grupo de Pesquisa Epistemologia e Educação; líder do Grupo de Pesquisa Sur Paideia. Membro da Comissão Institucional de Pesquisa e Iniciação Científica da UTP; membro da Comissão de Editoração Científica da UTP. Coordenador da Linha de Pesquisa Políticas Públicas e Gestão da Educação do PPGED da UTP. Autor de diversos livros e artigos, dentre os quais: Os Filósofos e a Educação (Argos, 2014); Mas afinal. Para quê, então, Filosofia? (UFFS, 2018)

\section{GILVANIA GUEDES TEIXEIRA}

Psicóloga, graduada em 2018 pela Universidade Potiguar (UnP) - Laureate International Universities, em Natal/RN. Atua na área de psicologia clínica com foco em atendimento infantojuvenil.

\section{GRAZIELA SAPIENZA}

Psicóloga e Doutora em Ciências pela Universidade Federal de São Paulo (Unifesp). Especializações em Terapia Comportamental e Cognitiva (USP) e em Adolescência (Unifesp). Professora adjunta de Psicologia (PUC-PR). Coordenadora da Especialização em Terapia Comportamental e Cognitiva em Saúde (PUCPR). Experiência em atendimento clínico e com programas preventivos nos campos de educação e saúde atuando com os seguintes temas: competência social, habilidades sociais, problemas de comportamento, práticas educativas parentais, fatores de risco e proteção em adolescentes, obesidade e uso de tabaco.

\section{HORÁCIO MEDEIROS JÚNIOR}

Psicólogo, graduado em 2018 pela Universidade Potiguar (UnP) - Laureate International Universities. Atua na área de psicologia clínica através da abordagem Gestalt Terapia.

\section{JOÃO LAIR ALVES}

Possui graduação em Educação Física e Licenciatura Plena- UPF (1992), especialização em Gestão da Segurança na Sociedade Democrática - ULBRA (2008) e especialização em Gestão Escolar - SENAC (2014). É 1 o Tenente da Brigada Militar do Estado do Rio Grande do Sul. Em sua trajetória atuou como Comandante do Corpo de alunos do Colégio Tiradentes e foi professor da disciplina curricular de Instrução Cívico Militar e extracurricular professor de Esgrima, atuou também como professor de saúde física nos diversos cursos de formação da Brigada Militar e é membro da Comissão de Pesquisa e Avaliação Física da Brigada Militar, desde 1993.

\section{JOELCI MORA SILVA}

Doutora em Educação (Linha de Pesquisa Educação, Psicologia e Prática Docente) pela Universidade Federal de Mato Grosso do Sul (UFMS). Mestre em Educação (Linha de Pesquisa Educação, Psicologia e Prática Docente) pela UFMS. Licenciada em História pela UFMS, possuindo também curso em Análise de Sistemas (SEIC). Atua como professora substituta no curso Licenciatura em História - Universidade Federal de Mato Grosso do 
Sul, nas disciplinas Teorias e Metodologias da História, História Antiga e História Contemporânea (desde março de 2018). Trabalhou como professora substituta da disciplina de Metodologias da História, História Antiga, História Regional, Estágio e Trabalho de Conclusão de Curso no curso Licenciatura em História - UFMS. Foi professora voluntária do curso Licenciatura em História - UFMS nas disciplinas de Prática de Ensino em História II, Prática de Ensino em História III e Estágio Supervisionado II. Atuou na Coordenadoria de Educação Aberta e a Distância (EAD - UFMS) como professora pesquisadora nos cursos de Licenciatura em Pedagogia e Pós-graduação, em nível de especialização, Gestão de Políticas Públicas em Gênero e Raça e como professora conteudista no curso de extensão Produção de Material Didático para a diversidade. Possui experiência nas áreas de Informática educacional, Informática empresarial, formação de professores, treinamento empresarial e atendimento ao cliente. Pesquisadora nas áreas de Psicologia, Educação e Prática docente, com o foco no tema Tecnologias na Educação. Foi integrante do Grupo de Estudos e Pesquisa em Psicologia e Educação - GEPPE.

\section{JOELSON JUK}

Professor do Ensino Básico, Técnico e Tecnológico do campus Campo Largo do IFPR. Doutor em Educação (UTP, 2019). Mestre em Sociologia (UFPR, 2002). Licenciado em Filosofia com habilitação em Filosofia, História e Sociologia (PUC-PR, 1996). Experiência em docência, cargos e funções de gestão na iniciativa pública e privada. Integra dos grupos de pesquisa Epistemologia e Educação e SUR PAIDEIA (PPGED-UTP). Autor de trabalhos em periódicos e eventos acadêmico-científicos. Coautor do livro Ética na Gestão Pública (Curitiba: IFPR, 2011); autor de capítulo do livro Filosofia e ensino: possiblidades e desafios (Ijuí: Unijuí, 2003) e do livro Contradições e desafios na educação brasileira (Ponta Grossa: Atena Editora, 2019)

\section{JOSÉ DE ARIMATEIA DE OLIVEIRA SILVA}

Graduado em Geografia (licenciatura) pela Universidade Estadual da Paraíba (2017). É Mestrando em Geografia pelo Programa de Pós Graduação em Geografia - PPGG/UFPB. Tem experiência na área de Geografia, com ênfase na Geografia Agrária, atuando principalmente com temas, como Reforma Agrária; Luta pela terra; Assentamento rural; Território e territorialidade.

\section{JOSÉ EUZÉBIO DE OLIVEIRA SOUZA ARAGÃO}

Graduado em Administração (UNICEP) e em Ciências Sociais com ênfase em Sociologia (UFSCar). Especialista em Administração (UJJT). Mestre e Doutor em Educação (UFSCar). Professor do Departamento de Educação e do Programa de Pós-Graduação em Educação da Universidade Estadual Paulista (UNESP) - Campus de Rio Claro. Experiência em Sociologia, Educação e Administração, tendo pesquisas sobre os seguintes temas: Ensino Superior; Gestão Educacional; Cinema, Educação e Sociedade; Cinema na Escola e Ensino de Administração.

\section{JOSE OTAVIO DA SILVA (In memoriam)}

Doutorando em Educação-UNIM, Mestre em Educação pela Universidade Federal da Paraíba-UFPB (1999). Especialista em Pesquisas Educacionais e Gestão da Educação (1997-1998). Possui graduação em Geografia pela Universidade Estadual da ParaíbaUEPB (1989) e Graduação em Pedagogia pela Universidade Federal da Paraíba-UFPB (1989). Atualmente é professor substituto na Universidade Estadual da Paraíba$\mathrm{UEPB} / \mathrm{CH} / \mathrm{DE}$, lecionando os componentes curriculares: Fundamentos e Metodologia do 
Ensino de Geografia, Gestão educacional, Estágio Supervisionado em Gestão Educacional e Pesquisa em Educação. Tem experiência na área de Ensino de Geografia e Educação, com ênfase em ensino e pesquisa no ensino de geografia e Políticas Educacionais, Gestão Educacional, Planejamento, Avaliação, Educação e Trabalho e Ensino e Metodologia do Ensino de Geografia e Metologia Científica, atuando principalmente nos seguintes temas: Ensino de Geografia, Estado, Escola, Educação, Ensino, Metologia do Ensino,Pesquisa Educacional, Gestão e Políticas Educacionais. É professor-orientador de TCC nos cursos de Geografia e Pedagogia da UEPB/CH/DE na área de ensno de geografia, gestão e planejamento da educação, participando também de bancas examinadoras de trabalhos de conclusão de curso e monografias da área de geografia e educação.

\section{KARLLINY MARTINS DA SILVA}

Mestre em Educação, no Programa de Pós Graduação em Educação da Faculdade de Ciências e Tecnologia (FCT), Campus de Presidente Prudente, SP. Graduada em Letras (Língua Portuguesa e Inglesa) e em Pedagogia. Membro do Grupo de Pesquisa de Formação de Professores, Políticas Públicas e Espaço Escolar da Faculdade de Ciências e Tecnologia- UNESP/Presidente Prudente, SP (GPFOPE) e do Grupo de Estudos e Pesquisas sobre Escola Pública e Profissionais da Educação (GEPEPPE) da FCT/UNESP. Atualmente é Coordenadora Pedagógica na Escola Municipal "Professora Teresinha Bombonati", Birigui, SP, desde 2015. https://orcid.org/0000-0001-8653-3411

\section{KATANA DE FATIMA DINIZ BOAES}

Doutora em educação, Mestre em educação, Especialista em Fisiologia do Exercicio, especialista em Coordenção Pedagógica e Gestão, graduada em Licenciatura em Educação Física pela Universidade Federal do Maranhão - UFMA. Professora concursada da rede estadual do Maranhão do ensino médio, Professora concursada da rede municipal de São Luis - MA, Coordenadora e professora do Curso Licenciatura e Bacharelado em Educação Física do Instituto Superior Franciscano - IESF.

\section{LUCIANA DANTAS SARMENTO DA SILVA}

Possui Graduação em Pedagogia pela Universidade Federal de Campina Grande (2007), Especialização em Psicopedagogia Institucional pelo Instituto Superior de Educação de Cajazeiras (2008), Especialização em Educação Profissional Integrada à Educação Básica na Modalidade de Jovens e Adultos pela Universidade Federal da Paraíba e Mestrado em Educação também pela Universidade Federal da Paraíba (2015). Atualmente é Coordenadora Municipal da educação Inclusiva do município de São João do Rio do Peixe.

\section{MANOILLY DANTAS DE OLIVEIRA}

Licenciada em Pedagogia pela Universidade Federal do Rio Grande do Norte. Mestranda em Educação pela Universidade Federal do Rio Grande do Norte - UFRN, na linha de pesquisa: Educação, comunicação, linguagem e movimento. Bolsista pela Coordenação de Aperfeiçoamento de Pessoal de Nível Superior - CAPES, pesquisando, os seguintes temas: Literatura Infantil e formação de leitor; literatura infantil com temática indígena; projeto gráfico do livro de literatura infantil. Membro do grupo de pesquisa Ensino e Linguagem do Centro de Educação da UFRN. 


\section{MARA CRISTINA FORTUNA DA SILVA}

Mestre em Educação pela Universidade Federal Fronteira Sul - Campus Chapecó. Especialista em Metodologia do Ensino de História (IBEPEX). Especialista em Educação do Campo pela Universidade Federal do Paraná - UFPR. Especialista em Educação Especial Universidade Federal do Rio de Janeiro - UFRJ. Graduada em História pela Faculdade de Filosofia, Ciências e Letras de Palmas/PR. Graduada em Pedagogia pela Universidade Estadual do Centro Oeste - Unicentro - Irati. Docente da Secretaria de Estado da Educação SEED-PR, atuando com Atendimento Educacional Especializado em Salas de Recursos Multifuncionais. Docente na Universidade Federal da Fronteira Sul - Campus Chapecó. Possui experiência na Educação Especial e Inclusiva, atuando principalmente nas seguintes áreas: Educação Especial e Inclusiva, Deficiência Visual, Deficiência Intelectual, Transtornos Globais do Desenvolvimento.

\section{MARCELA IESSA SCHMIDLIN}

Graduada em Psicologia e Especialista em Psicologia Analítica pela PUCPR, Diretora geral da Clinica Terapêutica Brumas. Psicoterapeuta em clínica particular.

\section{MARIA APARECIDA BOVÉRIO}

Pós-Doutorado em Educação Escolar, linha de pesquisa: Políticas, Gestão e o Sujeito Contemporâneo pela UNESP, Campus de Rio Claro. Doutora e Mestra em Educação Escolar, linha de pesquisa: Política e Gestão Educacional pela UNESP, Campus de Araraquara. Especialista em Planejamento e Gestão de Organizações Educacionais pela UNESP, Campus de Araraquara. Graduada/Licenciada em Letras (Português e Inglês) pelo Centro Universitário Moura Lacerda, Campus de Ribeirão Preto/SP. Professora titular da Faculdade de Tecnologia (FATEC), de Sertãozinho/SP. Professora da FATEC de Jaboticabal/SP. Docente e gestora no Instituto Educacional de Monte Alto/SP, mantenedor da Faculdade de Monte Alto/SP. Possui experiência com pesquisas na área educacional e multidisciplinar, bem como experiência com a edição de simpósios e revistas acadêmicas.

\section{MARIA EMÍLIA PINTO VILARINHO RODRIGUES BARROS ZÃO}

Licenciada e mestre em Ciências da Educação pela Faculdade de Psicologia e Ciências da Educação da Universidade do Porto, e fez o doutoramento na mesma área, especialidade de Política Educativa, na Universidade do Minho. Atualmente é professora do Departamento de Ciências Sociais da Educação do Instituto de Educação da Universidade do Minho, investigadora do Centro de Investigação em Educação da mesma universidade e é a provedora da Santa Casa da Misericórdia de Esposende.

\section{MARIANNA MOREIRA CLEMENTINO SANTOS}

Licenciada em Pedagogia pela Universidade Vale do Acaraú - UVA. Licenciada em Geografia pela Universidade Estadual da Paraíba - UEPB. Pós-graduanda em Geografia, Território e Planejamento Urbano, Rural e Ambiental pela Universidade Estadual da Paraíba - UEPB. Professora da rede Estadual de Educação da Paraíba - SSE/PB. Professora do curso Técnico em Guia de Turismo pela Secretaria Estadual de Educação da Paraíba SSE/PB. 


\section{MARIZA ROTTA}

Doutora em Educação - Programa de Pós-Graduação em Educação - PPGE/PUCPR - Linha de pesquisa História e Políticas da Educação. Mestre em Ciências Jurídicas com concentração na área de Direitos da Personalidade - PPGD/CESUMAR - Linha de pesquisa Tutela Jurídica Privada e Constitucional dos Direitos da Personalidade (2008). Graduada em Direito pela Faculdade Mater Dei (2004) e em Pedagogia - Habilitação Supervisão Escolar - FAFI (1996). Atuando nas áreas de políticas educacionais, formação de professores e meio ambiente.

\section{MATILDE GONÇALVES MENDES}

Possui graduação em Pedagogia pela Universidade Federal de Campina Grande (2008). Tem especialização na área da Educação Profissional Integrada a Modalidade de Educação de Jovens e Adultos. Mestre em Educação pelo do Programa de Pós-graduação em Educação da UFPB na linha de Políticas Educacionais (2014). Tem atuação profissional no Serviço Social do Comércio. Tem experiência na área de Educação, com ênfase em Coordenação Pedagógica, atuando principalmente nos seguintes temas: Políticas Públicas, Gestão e Financiamento

\section{MONICA DE FATIMA GUEDES DE OLIVEIRA}

Doutoranda em Ciencias da Educação pela UAA_ Universidade Autonoma de Assunção PY. Mestre em Educação pela Universidade Federal da Paraíba. Especialista em Supervisão Escolar-UFPB. Graduada em História e Pedagogia -UFPB. Professora da Universidade Estadual da Paraíba do Departamento de Educação - CH. Coordenadora Adjunta do Curso de Pedagogia da UEPB-Universidade Estadual da Paraíba, Campus III. Professora da Área de Instrumentação das Práticas Pedagógicas. Coordenadora Local do Polo de Guarabira pelo PARFOR.

\section{NAYANE HELLEN MAMEDE GUEDES}

Graduada em Pedagogia pela Universidade Estadual da Paraíba-UEPB(2019).Mestranda em Ciencias da Educação pela UAA- Universidade Autonoma de Assunção-PY. (2019)

\section{NIVANIA FERREIRA DA SILVA}

Possui graduação em Pedagogia (2010) e em Normal Superior -1ํo ao 5o ano (2009) pela FADIMAB - Faculdade de Ciências e Tecnologia Professor Dirson Maciel de Barros, especialização em Psicopedagogia (2011) pela FADIMAB - Faculdade de Ciências e Tecnologia Professor Dirson Maciel de Barros e Mestranda do Mestrado Profissional em Educação do PPGE da UPE Campus Mata Norte (2016). Atualmente é professora da Escola Municipal Governador Moura Cavalcanti, lecionando nas primeiras e segundas fases da modalidade EJA e supervisora de ensino na Escola Municipal de Referência Anita Moraes, localizadas no município de Macaparana - PE. Tem experiência na área de educação, como professora, na Educação Infantil, Anos inicias do Ensino Fundamental e EJA. Identifica-se com temas sobre alfabetização, inclusão, práticas educativas, currículo, políticas educacionais, relacionados principalmente à Educação de Jovens e Adultos.

\section{PALLOMA MARIA GOMES JÁCOME}

Graduada em Serviço Social pela Universidade Estadual da Paraíba - UEPB, em 2011; Especialista em Saúde da Família e Saúde Pública pela Faculdade Santa Maria - FSM (Cajazeiras/PB), ano de 2018. Mestra em Serviço Social pela Universidade Federal da 
Paraíba, em 2019; Docência do Curso de Serviço Social da Faculdade de Filosofia e Letras de Cajazeiras - FAFIC; Assistente Social do Centro de Reabilitação - CER VI- para pessoas com deficiência; Professora substituta do Curso de Serviço Social da Universidade Federal de Campina Grande - UFCG, entre os anos de 2015 a 2017.

\section{PATRICIA VERONICA NASCIMENTO DIAS FERNANDES}

Doutora em Ciências da Educação pela Universidade do Minho em 2017. Mestra em Ciências Sociais pela UFRB em 2012. Especialista em Metodologia do Trabalho Científico e Formação do Profissional Pesquisador. Graduada em Biblioteconomia e Documentação pela Universidade Federal da Bahia em 2002.

\section{PAULO ANTONIO DA GRAÇA LIMA ZUCCOLOTTO}

Graduado em Administração pela Pontifícia Universidade Católica de Campinas (1981) e Mestre em Engenharia de Produção pela Universidade Federal de São Carlos (2000). Atualmente é diretor da Faculdade de Administração da Pontifícia Universidade Católica de Campinas e professor assistente da Pontifícia Universidade Católica de Campinas. Tem experiência na área de Administração, com ênfase em Administração da Produção, atuando principalmente nos seguintes temas: Administração, Ensino da Administração, Gestão do Ensino do Ensino Superior, Metodologias Ativas de Aprendizagem (APB/PBL Aprendizagem Baseada em Problemas), energia e meio ambiente.

\section{RICARDO RODRIGUES MAGALHÃES}

Graduado em Administração pela Universidade Potiguar (2008) e Mestre em Educação Profissional pelo Instituto Federal de Educação, Ciência e Tecnologia do Rio Grande do Norte - IFRN (2016). Atualmente, exerce cargo de Administrador no Ministério da Economia no Rio Grande do Norte.

\section{ROSANGELA MARIA BOENO}

Doutora em Educação pela Pontifícia Universidade Católica do Paraná - PUCPR. Possui mestrado em Educação pela PUCPR, especialização em Pedagogia Escolar - ênfase em Administração, Supervisão e Orientação Educacional; Neuropsicologia; Docência no Ensino Superior. Possui graduação em Pedagogia pela Universidade Estadual do Oeste do Paraná (2000). Atualmente é professora adjunta do magistério superior da UNIVERSIDADE TECNOLÓGICA FEDERAL DO PARANÁ - CÂMPUS DOIS VIZINHOS. Tem experiência na área de Educação, atuando principalmente com os seguintes temas: políticas educacionais, formação de professores e processo ensino-aprendizagem.

\section{SAYONARA FERNANDES DA SILVA}

Possui graduação em Letras - Português e Literatura pela Universidade Federal do Rio Grande do Norte - UFRN (1997). Graduada em Pedagogia - Licenciatura plena pela Universidade Vale do Acaraú - CE (2012). Tem experiência na área de Letras, com ênfase em Linguística, Leitura e Produção de texto e Literaturas. Experiência na Educação Infantil como Professora e Coordenadora Pedagógica. Experiência em Gestão Educacional. Professora de Língua Portuguesa, Redação e Literatura Brasileira no Ensino Médio - SEECRN. Professora formadora na área de Literatura Infantil e Ensino da Língua Portuguesa para alunos do Ensino Médio na Modalidade Normal - SEEC- RN. Formadora do Programa de Correção de fluxo da Secretaria Municipal de Educação- SME/ Natal - RN. Pósgraduada em nível de especialização em Psicopedagogia pela Universidade Potiguar ? UNP (2003) e em Educação Infantil pelo Instituto de Educação Superior Presidente 
Kennedy - IFESP (2010). Mestra em Educação pela Universidade Federal do Rio Grande do Norte - UFRN (2015). Doutoranda em Educação pela Universidade Federal do Rio Grande do Norte - UFRN, na linha de pesquisa: Educação, comunicação, linguagem e movimento. Bolsista pela Coordenação de Aperfeiçoamento de Pessoal de Nível Superior CAPES, pesquisando, principalmente, os seguintes temas: políticas públicas de leitura com ênfase no PNBE; ilustração do livro para infância; literatura infantil; mediação de leitura e a formação do leitor na Educação Infantil. Membro do grupo de pesquisa Ensino e Linguagem da UFRN. Estágio Doutoral pela Universidad Complutense de Madrid com estudos sobre leitura e escrita criativa da Facultad de Educación e do Centro de Formación del Profesorado - UCM (2018).

\section{SEVERINO DO RAMO PEREIRA DE LIMA}

Especializando em Geografia pela Universidades Estadual da Paraíba. Estudos voltados na área de Geografia Agrária, membro do CEAT - Centro de Estudos Agrários e do Trabalho UEPB; do TERRA - Grupo de Pesquisa Urbana, Rural e Ambiental - UEPB e do Grupo Olhares Geográficos- UEPB.

\section{SÔNIA DA CUNHA URT}

É graduada em Psicologia, Pedagogia e Administração de Empresas. Mestre em Educação (Psicologia da Educação) pela Pontifícia Universidade Católica de São Paulo (1989) e Doutora em Educação com ênfase em Psicologia Educacional pela Universidade Estadual de Campinas (1992). Fez estudos de Pós-Doutoramento pela Unicamp e pela Universidad de Alcalá de Henares - Espanha e Universidade de Lisboa - Portugal. Atualmente é professora Titular dos Programas de Pós-Graduação em Educação e em Psicologia da Universidade Federal de Mato Grosso do Sul. Tem experiência na área de Educação, com ênfase na interface Psicologia e Educação, atuando em ensino, extensão e pesquisa principalmente com os seguintes temas: Identidade, Aprendizagem, Constituição do Sujeito em Espaços Educativos/Formação e Adoecimento do Professor. Personagens/Biografias e Autobiografias. Psicologia e Educação: Contornos e Possibilidades Sob o Enfoque das Políticas Públicas/Aporte da Teoria Histórico-Cultural. Estudos acerca da Violência Escolar: Formas de Enfrentamento no Âmbito da Psicologia e da Educação.

\section{SORAYA CUNHA COUTO VITAL}

Doutoranda em Educação pela Universidade Federal de Mato Grosso do Sul (UFMS) Bolsista CAPES. Mestre em Psicologia - Psicologia e Processos Educativos, pela Universidade Federal de Mato Grosso do Sul (UFMS). Membro do GEPPE - Grupo de Estudos e Pesquisas em Psicologia e Educação da Fundação Universidade Federal de Mato Grosso do Sul (UFMS). Possui graduação em Letras - Português, Inglês e Respectivas Literaturas, pela Universidade Anhanguera Uniderp (2011) e graduação em Pedagogia pela Faculdade de Campo Grande (2003). Tem experiência na área de Educação, com ênfase em Psicologia Educacional, atuando principalmente nos seguintes temas: educação integral, violência escolar, formação de professores, oratória, atualização e performance.

\section{VANDA MOREIRA MACHADO LIMA}

Doutora pela USP/São Paulo (2007); Mestre em Educação pela UNESP/ Marília-SP (2003) e graduada em Pedagogia pela UNESP/ Presidente Prudente-SP (1998). Líder do Grupo de Estudos e Pesquisas sobre Escola Pública e Profissionais da Educação (GEPEPPE) da FCT/UNESP. Atualmente é Professora Assistente Doutor na Universidade Estadual Paulista (UNESP) na Faculdade de Ciências e Tecnologia (FCT),Campus de Presidente 
Prudente, SP, lecionando nos cursos de graduação em licenciatura (desde 2009) e do Programa de Pós-Graduação em Educação da FCT/UNESP (desde 2016). Membro do Grupo de Estudos e Pesquisas sobre a Formação de Educadores da Faculdade de Educação da Universidade de São Paulo (USP), São Paulo (GEPEFE/FEUSP), desde 2004 e membro do CENTRO DE ESTUDOS DO TRABALHO,AMBIENTE E SAÚDE (CETAS) da FCT/UNESP desde 2018. Desenvolve pesquisas na área de FORMAÇÃO DE PROFESSORES, PROFESSOR POLIVALENTE (ANOS INICIAIS), CURSO DE PEDAGOGIA, POLÍTICAS EDUCACIONAIS e GESTÃO EDUCACIONAL com ênfase no espaço da escola pública de Educação Básica. Foi Coordenadora do curso de Pedagogia da FCT/UNESP de 2014 ate agosto/2018).

\section{VANESSA TERRA PEREIRA}

Bacharel em Biblioteconomia, pela Universidade Estadual Paulista "Júlio de Mesquita Filho" (UNESP), Campus de Marília. Especialização em Planejamento e Gestão de Organizações Educacionais, pela Universidade Estadual Paulista "Júlio de Mesquita Filho" (UNESP), Campus de Araraquara. MBA em Gestão Empresarial - Programa de Pósgraduação, pelo Instituto Educacional de Monte Alto, Faculdade de Monte Alto, Monte Alto/SP. Mestrado em Educação, pelo Programa de Pós-Graduação em Educação do Instituto de Biociências da Universidade Estadual Paulista "Júlio de Mesquita Filho" (UNESP), Campus de Rio Claro /SP.

\section{VÂNIA APARECIDA CALADO}

Possui graduação e licenciatura em Psicologia pela Universidade de São Paulo. Concluiu mestrado no Programa de Psicologia Escolar e do Desenvolvimento do Instituto de Psicologia da USP. Atualmente é aluna de doutorado do Programa de Pós-graduação em Psicologia da UFRN. Atua como coordenadora do Serviço Integrado de Psicologia, professora do curso de Psicologia e do curso de Pós-Graduação em Psicologia Clínica e Psicoterapia Infantil da Universidade Potiguar - Laureate International Universities, Natal, RN. 


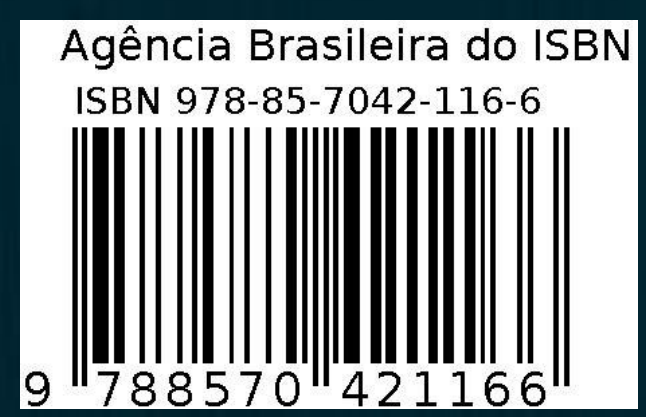

